Louisiana State University

LSU Digital Commons

1955

\title{
Thomas Hooker and the Reformed Theology: The Relationship of Hooker's Conversion Preaching to Its Background.
}

\author{
Everett Harvey Emerson \\ Louisiana State University and Agricultural \& Mechanical College
}

Follow this and additional works at: https://digitalcommons.Isu.edu/gradschool_disstheses

Part of the English Language and Literature Commons

\section{Recommended Citation}

Emerson, Everett Harvey, "Thomas Hooker and the Reformed Theology: The Relationship of Hooker's Conversion Preaching to Its Background." (1955). LSU Historical Dissertations and Theses. 8124.

https://digitalcommons.Isu.edu/gradschool_disstheses/8124

This Dissertation is brought to you for free and open access by the Graduate School at LSU Digital Commons. It has been accepted for inclusion in LSU Historical Dissertations and Theses by an authorized administrator of LSU Digital Commons. For more information, please contact gradetd@lsu.edu. 
THOWAS HOOKER AND PHE RLFORHED THEOLOGY:

THE RELATIONSHIP OF

HOOKER'S CONVERSION PREACHING TO ITS BACKGROUND

\section{A Dissertation}

Submitted to the Graduate Faculty of the Louisiana: State University and Agricultural and hechanical College

in partial fulfillment of the requirements for the degree of

Doctor of Philosophy

in

The Department of English

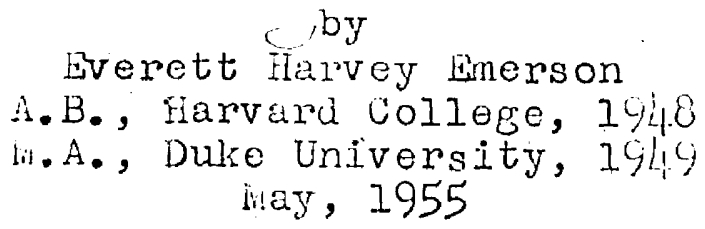




\section{All rights reserved}

INFORMATION TO ALL USERS

The quality of this reproduction is dependent upon the quality of the copy submitted.

In the unlikely event that the author did not send a complete manuscript and there are missing pages, these will be noted. Also, if material had to be removed, a note will indicate the deletion.

UMI DP69502

Published by ProQuest LLC (2015). Copyright in the Dissertation held by the Author.

Microform Edition (C) ProQuest LLC.

All rights reserved. This work is protected against

unauthorized copying under Title 17, United States Code

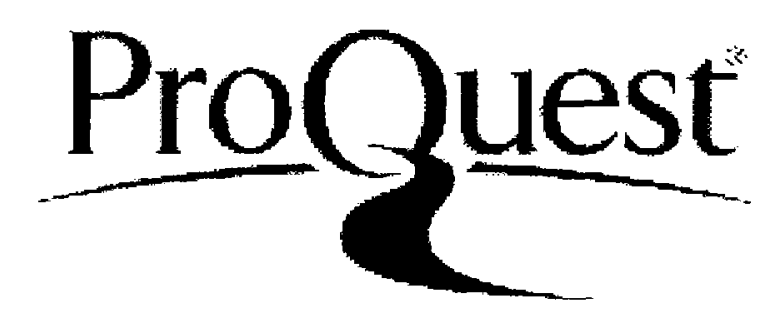

ProQuest LLC.

789 East Eisenhower Parkway

P.O. Box 1346

Ann Arbor, Ml $48106-1346$ 
I wish to thank the following people for their help in preparing this study: Professor D. E. Stanford, who directeda my work and supplied me with good advice; proressor i. L. Warilla, who read the study and helped much with stylistic matters; Professor I. S. K. Scott-Craig, of Dartmouth College, who supplied several valuable suetestipns; and my wife.

In preparing this study I have made use of the facilities of the Loulsiana State Univergity Library and of the widener Wemorial; Andover-Harvard, and Houghton libraries of Harvard University. Through the courtesy of interlibrary loan I have had access to books in many other libraries; those of the University of Chicago and Yale University have been particularly helpful. 'The officials of the library and the Departmont of snglish of Loulsiana State University made this study possiblo by procuring for my use tie microfilns on which the study is largely bused. To these Iibrurles, librarians and others I an vexy diatelul.

without two notable compliations, thilin ischafi's Creeds of Christendom and He indicin Heppe's irelormed Dogmat1es, tho work involved in tilis sbudy would hive been. Increased immeasuritily.

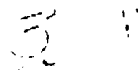


TABLE OF CONTENTS

CHAP'PR

PAGE

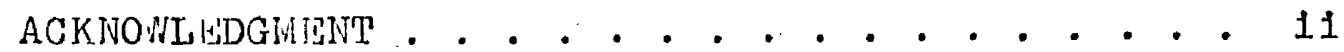

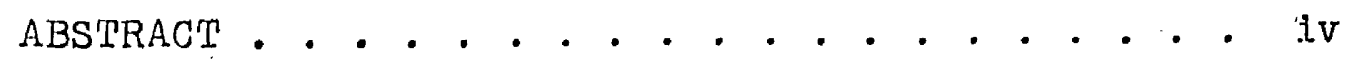

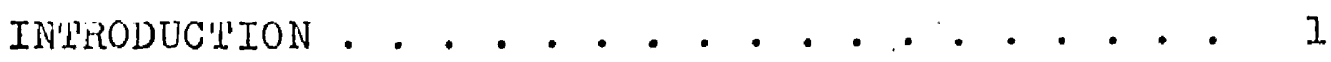

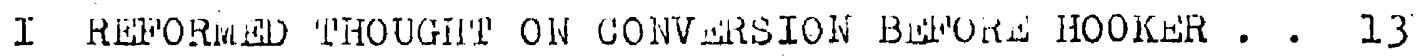

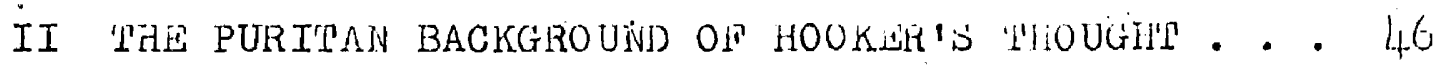

III THOWAS HOOKER'S 'PHEOLOGY AND WHFICS, AND HIS

CONCEPT OF PHI IROLE OF PREACHIHG . • . • • . . 98

IV HOOKER, COVEHANT RHELOGY, MW WHAS SHRON AS

THE MEANS OF GRACE . . . . . . . . . . • . 132

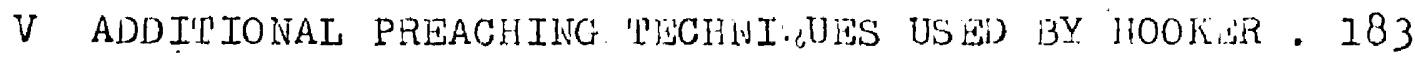

VI SHEPARD AND COIIOH IU RELARION TO HOOKLR ." • . 204 COHCLUSION . . . . . . . . . . . . . . 241 * SELECTED BIBLIOGRAPHY . . . . . . . . . . . 246

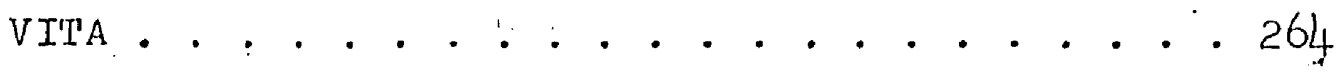




\section{ABS'PRA'C}

Recent students of New England Puritanism have argued that the theology of such writers as John cotton, Phomas Shepard, and Thomas Hooker" is not to be confused with CaIvinism, for it differs in important ways: it is covenant theology, a later development of the Reformed theology which put more emphasis on man's splipitual ability and less on" prodestination. This dissertation examines the teacinings of the Inportant Puritan divine lhomas Hooker (1586-16/7) on conversion, in the light of 'Calvin's teaching and seventeentih-century Reformed and Puritan thoupht.

Puritan thought such as Hooker's differs from tino thought of Culvin in being more concerned with man's alvation and lesis conçonod with Gor's rlory. Prociestination was for Calvin a tenching which empirasized God's nercy and also ils justice; for puritans it was most inortunt ror its

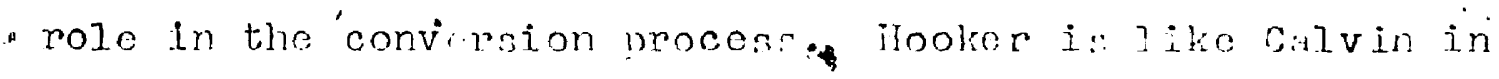

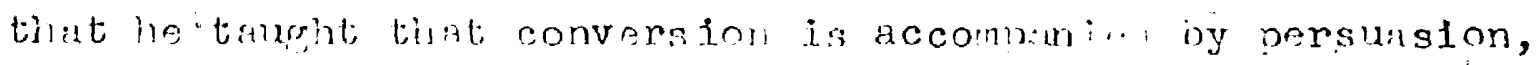
but unlike calvin ju that Gajvin aid not mak contral to

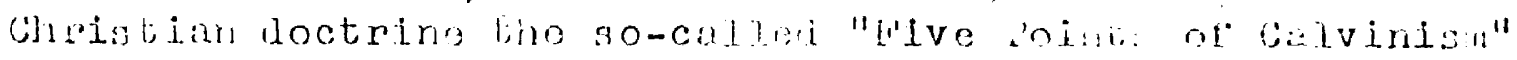

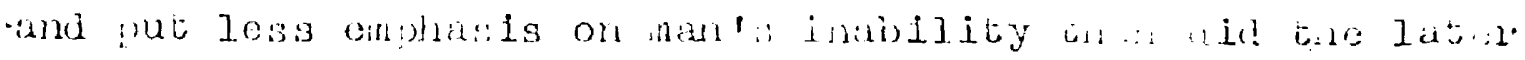

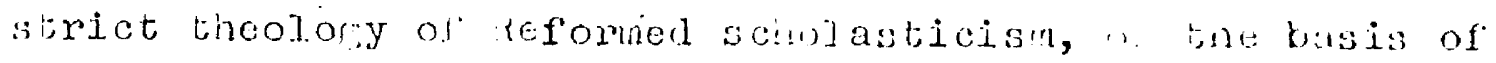
Which inoker's binment doveloni. 
The most important doctrine in understanding Hooker's conversion teaching is not the covenant but the sermon as a means of grace. According to this theory, the preacher's exhortations to take the steps necessary for conversion-such as contrition and humiliation--will by God's Erace so affect the elect that they will follow the preacher's directions. Preaching of the word has the effect of making the conversion process--actually) a result of God's irresistible grace-appear to be a matter of man's choice. Calvin taught this sacramental concept of preaching, although it did not loom large in his practice because he was not nekrly as concenned. with the salvation process as were later zeformed writers. But John Preston and others of his time developed the concept of 'the sormon as a means of' grace and related it to psycholofical processes. The developed doctrine provides the basis for many of Hooker's exhortations, which, to on'e unfamiliar with the doctrine, may sound siminian.

Hooker's most ef'fective preacining ability was his analysis of the "shifts" and ritionaliations by wisich men avoid taking the teps prencribed for salvation. These andyses are often in the form of chritcters.

iooker's thought is more rlosely rofitisi to the school

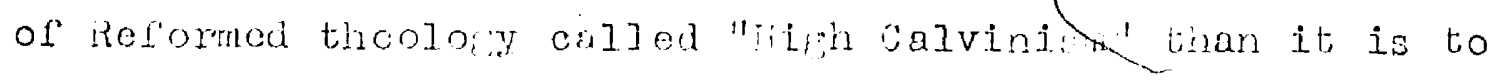

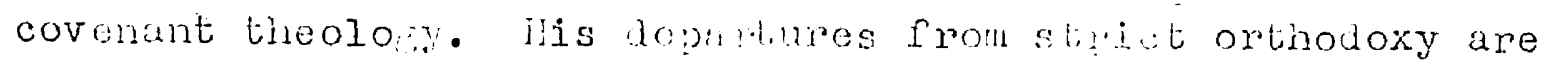
rare and not survising, consdering tho aidicullies of contaming at tio sane tino bind nan totall; lacks spiritual abldity and the 
his soul. 'Wo aspects of Hooker's thought appear to be Important weaknosses. Pirst, conversion has an ambicuous role In his teachings, for to the unconverted it is tho ultimate Boal, but those who reeard thomselves as converted may not enjoy assurance: they must continually tost theinselves to seo if they are really saved. Socond, Hookor teaches that conversion 1s a long and painful process but areues that those who fall to attempt the process are resisting God's freo Elft of Erace.

Cotton and Shepard, Hooker's contemporaries, differ'so consilerably from Hooker in the detal is of their teuchine on convorsion that the three canriot be sald to form a school of theology; they belone to the school of Calvin and his succosions, the Reformed theolory.

looker's groatent accoinplishmont, was his degree of success in reconcling aivino predostination and human responslbility, but his offort was not sufficlently successful to warpant for film an Important place in tho history of seventeontil-contury 1doas. 


\section{INRRODUCTION}

Thomas Hooker died at the age of sixty-one, yet had IIved long enough to establish a great reputation on both sides of the Atlantic. Cotton Mather called him "The Light of the Western Churches,"I while Samuel Collins, agent of Archbishop Laud, sald of him in 1629, "I have I1ved in Essex to see many changes and have seene the people 1dolizing many new ministers and lecturers; but this man surpasses them all for learning, and some other considerable parts, and . . Eains more and far greater following than ail before him." 2 He was moro talked about than the question of tonnage and '. poundage. 3 In our own times he has been called "a statesman of the first rank, "l. "the father of American democracy," 5

\section{${ }^{1}$ In Magnal1a Christi Americana.}

2 Calendar of State papers: Domestic, 1628-1629, CXIII, 554, No. 113, quoted by Perry Miller, Mhoms Hooker and the Democracy of Early Connecticut," New England Quarterly, IV $(1931), 665$.

\footnotetext{
3 State Papers: Domest1c, 1628-1629, CXLIV, 567, No. 36, quoted by Miller, "Hooker," p. 665 .

4Warren Seymour Archibald, thomas Hookci (New Haven, 1933), p. 1 .

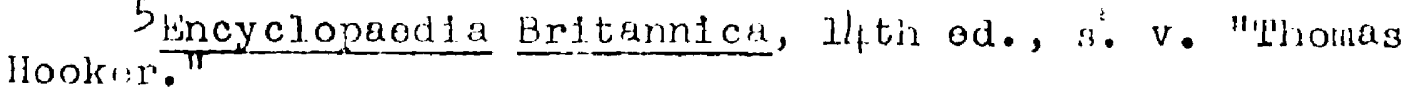


and the "noblest of the New England Puritans." 6 He has been ranked by the editors of the standard history of American Iiterature as a major author, 7 and it has been said that "There is great need for an adequate study of [Thomas Hooker, J one of the leading thinkers and writers of the seventeenth century." 8 The following study is an attempt to f1ll partially that need.

Thomas Hooker was born at Marfield, a tiny town in Leicestershire, England, in $1586.0^{9}$ Probably he attended, Market-Bosworth School, near Marfield, before he arrived in 1604 at Cambridge. There he matriculated as a sizar at Quéen's College ${ }^{10}$ but later transferred to Eminanuel College, where he recelved the bachelor's degree in 1608 and the mas ter's degree in 1611. Since thirty-five of the 130 university-educated men who came to New england before 16.45 were

6Clinton Rositer," "Thomas Hooker," Now sngland Quarterly, XXV (1952), 461.

7Robert E. Spliler, Fenry Seldel Canby, at, al., Literary History of the Inited States (New York, Iy/y), VoI. III.

8 Thomas H. Joinson, Literary History of the United States, III, 569.

9This blograpilical summary is based in tile main on the standard (though. Inadequato) biography, "Thomas llooker, by George Leon Walker (New York, ].89).

$10 \mathrm{~A}$ sizar was a student who was exempt rrom college gharges because he performed certafn duties, such as waiting on table. 
Emmanuel men, ${ }^{11}$ it can readily be seen that Emmanuel waśs basically Purltan in outlook, as was Cambridge University as a whole at that time. Indeed, Emmanuel had been a Puritan college from 1ts establishment in 1584. Thomas Fuller, in his History of the University of Cambridge (1655) tells of a conversation between. (queen Elizabeth and Walter Mildmay, the founder of Emmanuel:

\footnotetext{
"Sir Walter, I hear you have erected a Puritan Foundation?"

"No, Madam," saith he. "Farre be it from me to countenance anything contrary to your established Lawes; but I have set an Acorn, which when it becomes an Oak, Gid alone knows what will be the fruit thereof."12
}

Hooker was associated with Cambridge unt1l 1618. There he must have come into contact with William Ames, spiritual godfather of the American Puritans and author of a book against ceremonles, which Hooker later helped to edit. 13 Hooker became a Dixie Fellow after his graduation, and in 1616 was Dean of the College. He left two years later to seek a parish, in accordance with the wishes of the founder

11 Samuel Eliot Morison, The Founding of Harvard College (Cambridge, Mass., 1935), pp. $358-363$.

12 wuoted by llorison, Founding of Harvard, p. 93. Among its fellows and students soon after Hooker's period were the Platonists Benjamin Which $\cot \theta$, Ralph Cudworth, and Nathanlel Culverwel. See A. T. Campagnac, lhe Cambridge Platonists (Oxford, 1901), pp. xv1, xxv11, and xxix. ${ }^{13}$ See Perry M11ler, Orthodoxy In Massacinusetts (Cam-
bridge, Mass., 1933), passim. 
of the College. ${ }^{14}$ John Cotton, later to migrate with him to Now England, was at, Bnmanuel while Hooker was there. 'But more important than any new acquaintance or high post was h1s conversion, or, to use phrases by which he later characterized such experiences, his iffectual Calling, and Implantation.into Christ. Hooker's theology, as we shall see, taught that pregeneration was necessary for salvation.

Fortunately for him, he was able to obtaln a place as a minister despite his nonconformist views. He came under the patronage of a Mr. Francls Drake, who awarded him the rectorship of the Parlsh, of Esther in Surrey, sixteen miles from London. Hooker apparently recielved the post because he had already become noted as an "experimental theologian": he was an expert religious psychologist. Wr. Drake's invalid wife was convinced that she had cominted the unpardonable sin, and since Hooker "now had no supertor, and scarce any equal, for the sk111 of treating a wounded soul,"15 1.t was porhaps natural that he should be called in. Apparently llookor holped her conslderably. While at wistiel he was married to hirs. Drake's waltine mald, Susarra.

In 1626 Hookur was appolnted Lecturor at Chelms ford, Essex, perhaps because he hul bocome famous both as a preachor and "as a phystcian of anuls. Many, pristiras fin tire

14 Morison, Fimringing of Harvarä, p. 100. I5cotion Mather, Muenalia christs Amoricurrs (Hurtiond, $1.8201, \mathrm{I}, 303$. 
early seventeenth century had a special, additional preacher or lecturer, often pald by wealthy Puritans and designed to supply better preaching than might be provided by the reguIar clergy. ${ }^{16}$ The system was very popular with the country people, who were dissatisfled with the liturgical, non- preaching services of the church. It was in this position at Chelmsford that Hooker reached the peak of his popularity in England. Many journeyed to Chelmsford especially to hear. him speak, and the whole county felt his influence. The clergy of the county split into two groups, his supporters and his opponents. The latter had the sympathy of Laud and won out; Hooker was silenced.. This was at the end of 1629 , the same year that Hooker's first published work, "The Poor Douting Christian Drawne Unto Christ," appeared. n Hooker, upon.his suppression, set up a school at Iittle Baddow, near Chelmsford, with John Eliot, later famous for his preaching to the Indians, as his usher. Although Hooker was not allowed to preach in any church, he was able to continue the work of the ministry since many ministers gathered with him monthly at meetings and a'so in private consultations. Thus Hooker's teachings were felt long after he was officially silenced. 17

In July, 1630, he was ordered to appear before the HIgh

16 William Haller, The Rise of Puritanis!l (New York, 1938), pp. 52-53.

17 Mather, Magnalia,; II, 305. 
Commission Court. Perhaps influenced by the mutilations that other nonconformist ministers had incurred, he fled to Holland. After a short stay in Amsterdam, he became connec-. ted with the Scottish Presbyterian Church at Delft, not as pastor, but as an assistant. Here he served about two years before returning to Amsterdam to be associated with William Ames, who soon died, leaving Hooker to edit Ames's last work, A Fresh Suit against Human Ceremonies in Gods Worship (1633).

Weanwhile plans were underway in England for Hooker's removal to Massachusetts. A group of settlers from Essex County had left in 1632 with the understanding that Hooker would soon join them in America. Indeed, the group was known as "Mr. Hooker's Company." Samuel Stone, a younger man, was chosen as Hooker's associate. Hooker returned to England in 1633, where he preached a farewell sermon, later published as The Danger of Desertion. 18 Soon afterwards Hooker, along with Stone and John Cotton, left England, arriving in Boston on September 4, i633.

Thomas Hooker had left England forever, but he was not forgotten there. Besides the two titles referred to above, over twenty works by Hooker were published in London before 1660, and many of them went through several editions: "The

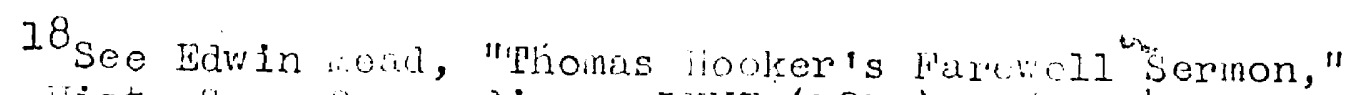
liass. Hist. Soc. Proceedings, LXVI (1913), 253-274.
} 
Poor Douting Christian," for example, went through six editions in the seventeenth century.

In America Hooker became pastor of the church at Newtown, but within a year he and his people were ready to move. Complaining that they did not have adequate land, they petitioned the General Court for permission to remove to the unsettled area of Connecticut. Finally Hooker and his poople left, though without formal permission, 19 and settled in 1636 at what was.t to become Hartford. Perry iriller has confectured that Hooker found irritating his proximfty to John Cotton, who had already become "the mouthpiece of the ruling oligarchy."20

Hooker returned to Massachusetts the following year to attend a synod, where he served with Peter Bulkley as moderator: Here the Antinomian heresy was condemned. On returning to Connecticut he played a very important role in formulating the "Fundamental orders" (1639), for which role his blographer calls him "the founder of the Connecticut Constitution." 21

In 1643 Hooker served as joint moderator with Cotton at the very important synod where presbyterianism was condemned. Shortly after, in order to clarify the New england position

$$
\begin{aligned}
& 19_{\text {Miller, "Hooker," pp. 673-674. }} \\
& 20_{\text {Miller, "Hooker," p. 676. }} \\
& 21_{\text {Walker, Hookor, p. } 123 .}
\end{aligned}
$$


on church disclpline to old England, Hooker wrote A Survey of the Summe of Church D1sc1pline. Unfortunately the ship cärring Hooker's manuscript to England never arrived, and Hooker, now in poor health, reluctantly rewrote it. His, "yeares and infirmityes"22 kept him from attendine the $1 \mathrm{~m}$ portant Cambridge synod of 16\%, and in the followine year he died. When on his death bed he was consoled by a visitor, "Sir, you are goine to receive the reward of your labour," Hooker replied, "Brother, I am going to receive mercy!" 23

In his own time Hooker was especially noted as an experimental theologian: in Cotton Mather's words

- - he entertained a special. Inciination to those principles of divinity, which concerned, the application of redemption; and that which eminently iltted him for the handline of those princlples, was, that he had been from his youth trained up in. the experlence of those humiliations and consolations, and sacred communions, which belong to the new creature; and he had most critically compared his own experience, with the accounts which the quick and powerful word of God, gives of those glortous things. Accordingly he preached first more briefly on these points, whilst he was a catechist in Emanuel-College, In a more scholastic way; which was most agreeable to his present station; and the notes of what he then delivered were so esteemed, that many coples thereof were transcribed and preserved. Afterwards he preached more largely on these polnts, in a more popular way at Chelmsford, the product of which were those books of preparation for Christ, contrition, humlifation, vocation, union with Christ; and cominunion, and the rest, which go unier his name : . .

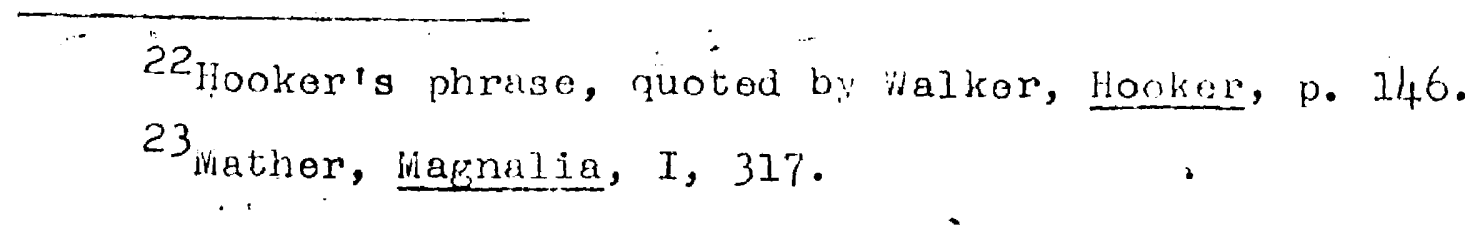


But when he came to New-England, many of his church, which had been his old Essex hearers, desired him once more to go over the points of God's regenerating works upon the soul of his elect; until at last, their desires prevalied with him to resume that pleasant subject. The subject hereby came to have a third concoction in the head and heart of one, as able to digest it, as most men living in the world

The following study attempts to consider Hooker's writing, especially his soterlological thought, and its relationship to the Reformed and Puritan traditions.

It is hoped that this investigation may serve as a corrective to recent scholarship in the history of ideas in the seventeenth century. This scholarship has been mainly the work of Perry Milier, although the Ereat historian Samuel Ellot Norision has also helped to establish a view of the Puritans very different from the older view that the Purltans were doctrinally Calvinists. Thus we read in Milier's "Miarrow of Puritan Divinity" that Jonathan Edwards was "the first consistent and authentic Calvinist in New. England";25 and ivioribon, in The Puritan Pronaos, proclaims that "after reading some hundreds of puritan sermons," he is "about ready to deny that the New England puritans were predestinarian Calvinists." 26 These works, along with Miller's The

$2 l_{\text {Iiagnalia, }} I, 31 / t-315$. 25 "litarrow," Pubs. Col. Soc. Mass., Proceedings, 19331937, XXXII, 300. 26 Pronaos. (New York, 1936), p. 10. Morison mukes the point that Inilier had made concerning Edwards.--p. 155. 
'New England Mind, have' convinced other workers in the field $\therefore$ that the Now England Puritans were important thinkers who revised substantially the theology. which they fell heir to as children of the Reformed tradition. Thus the important literary historian Douglas Bush has accepted Imller's findIngs and incorporated them into his standard study of seventeenth-century English literature. 27 In one of the best studies of Puritanlsm, that by M. M. Knappen, Miller's work on Puritan theology is cited with approval. 28 Likewise, the " notable historian Wallace Notestein, in a work likely to become a standard historical work, follows uncritically Miller's studies. 29 Again, Herbert W. Schneider, in his excellent study of American philosophy, leans heavily on Willer for his analysis of the iuritan theology. 30

The thoroughness of Mllieris readings in Now England Puritan sermon literature and the general excellence and carefulness of his studies are the factors which have led to the Influence of his work. Thus when he argues that covenant theology, a seventeenth-century developinent in Reformed theology, transformed the theolngy of New England to

27 inglish Literature in the Darlier Seventeenth Century,

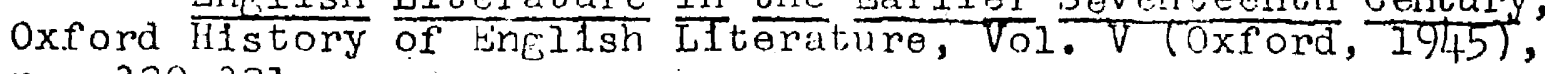
pp. $320-321$.

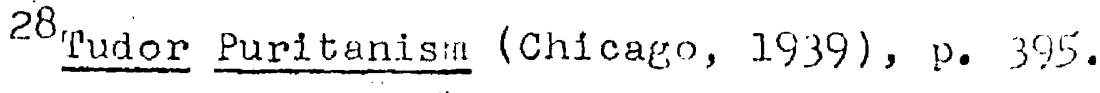

29 Phe English People on the sve of the Colonization, : New Anerican Nation Series, Vol. TNew York, 1954$),$ p. 159. pp. $4 \mathrm{ff}^{30}$ Alstory of American Phijogophy (New Yorle, 1946), 
something very different from what Calvin taught, Miller's readers have been prone to accept his findings since few have had the courage or the desire to read as widely as he has in the works of the period. 31 . Further, like Miller himself, most of his readers have been students of literature and history, not theology.

The basic weakness of Miller's studies is that they are not based on a familiarity with the writings of John CaIvin. Milier is indeed familiar with the Institutes, but it is hardly proper to compare the sermons of the puritans with a doctrinal work such as the Institutes of Calvin; other writings, especially his sermons, must be considered carefully

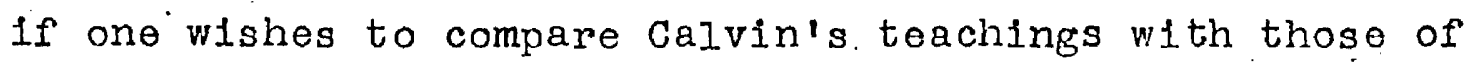
the New Englanders. 32

The following study is concerned with the history of 1deas. Although its scope is in some ways narrow, the

${ }^{31}$ It is perhaps proper to remark here that the present writer is a former student of Professor ivilier's and is one of his most ardent admirers, although he has found him to be not always infallible.

(132thus Herschel Baker, who relies on fililer's studies, declares that the development of covenant tireology in the seventeenth century was an indication that Calvinism was becoming more liberal and humanistic. Iike ililer, Baker fails to make clear what he thinks Calvinism is. Se $\theta$ The Wars of Truth (Cambridge, Mass., 1952), p. 242 and passim. AIso observe the implications of this statement by Thomas $H$. Johnson: "Boston and salem were not touched by Calvinism. - - Edwards as the first American Calvinist did not emphasize, like Thomas Shepard, Thomas Hooker, and other leaders among the seventeenth century puritans, the covenantal relation between God and man..." "--Itterary ilistory of the
United States, I, 75. 
author feels that he has been able to make several important observations, which, he hopes, may help to modify the present conception of the thought of the period.

One matter concerning the method of the study should perhaps be made clear. Frequently the divines whose works are studied below paraphrased or echoed Biblical passages in their works, as is hardly surprising, since they were all close students of the Blble. The author has not taken into consideration that such phrases are echoes or paraphrages; what is important in an historical study such as this is not the source of the lines but the fact that the divines selected these pàssages to support the1r arguments. 
CHAPTER I

REFORIVED RHOUGHT ON CONVERSION BEFORE HOOKER

\section{John CaIvin}

Priest, doctor, hermit, monk grown white With prayer, the broken-hearted nun, The martyr, the wan acolyte, The incense-swinging child,--undope Before God fashioned star or sun!

'lhese lines from Robert Browning tre fairly typlcal of many modern interpretations of the theology of John Calvin. Indeed, in one recent textbook of theology the lines are cited as a "vivid presentation" of one aspect of calvin's system. ${ }^{2}$ Because Calvin and Calvinism have often been misrepresented, this discussion of Calvin's teaching on the process of salvation will attempt to compensate for the customary false plcture of Calvinism as immoral and almost sacrilegious, and tuerefore will have a rather different emphasis than would otherwise be required.

Traditioneliy, Cajvinism is represented us centering around five points of dogma: double predestination lelection

\footnotetext{
I"Johunnes Agricola in lieditation," 11. 1-b5.

2Claude B. woss, "l'he Chrisulun wath: An lntroduction

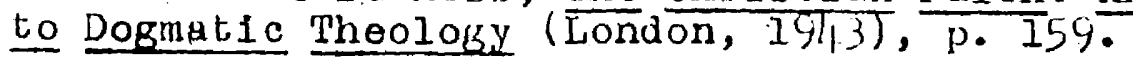


and reprobation); IImlted atonement (Christ died for only the elect); the total depravity of man; 1rresistible grace (the elect cannot choose but be saved); and the perseverance of the saints (those truly "called" to salvation will persist unt1l judgment day). As we shall see, these "five points" are not the basic features of calvin's theology. It is therefore useful to use the term "Calvinism" only when speakIng of Calvin's own teaching, using the terms "Reformed theology" or "predestinarianlam" when referring to the teaching of theologians, British and Continental, who were in the same non-Lutheran Protestant tradition as Calvin. ${ }^{3}$

The modem mind is likely to regard the theologiangas dwelling in unreality, where he bullds Gothic castles which become ever more intricate as now relationships are made botween the bullding blocks "Grace," "Free Will," "Predestination, "and the like. Although Calvin's system is intricate, he kept a close watch on reality, to which he constantiy related hls thought. Indeed, for one modern student of Calvin, A. M. Hunter, Calvin was not basically a theologian but a plous man, constitutionaliy religious, whose interest in theology resulted from his desire to support his religion. 4

The plety of Colvin is evident rrom the fact that the most important feature of his religlous thought is his sense

3The term "High Calvinist" is explained below. 4The Teaching of Calvin (London, 1950), p. 296. Th1s is also the viow of James D. Moffat, "Influence of Calvin on Religious Thought," Auburn Seminary Record, V (1909), 157. 
of the overwholming glory of God. This concept, along with Culvin's belief in the infalifbilty of the Holy Scriptures, leads to all the fundamental doctrines of Calvinism. The Elory or God is so great that all men by nature have "some sense of Deity," which should by ltself be enough to cause thein to worship God and consecrate their lives to His serv1ce.5 Much fuller knowledge of God the creator and God the Redeener than this sense of Delty is availuble to the "reciplent of the redemptive revelution," the elect, the saint of God. 6 In all, God's qualities include "powor, eternity, self-existence, wisdom, goodness, morcy, justice, richteousniss and truth," and, most importunt, "Eratuitous-mercy-knownin-Christ."7

But for Calvin, following st. paul, natural man since the Fill has been totally depraved: "all human destres àre ev11. - โfor! nothing pure and upright can proceod from a polluted nature." 8 Only the all-powerful God can do anything to narrow the tremendous gap between manis depravity and His righteousness, and the aim of what calvin calls the. "Scripture system" is the narrowing of the gap. 'lhis system has

SInstitutes of thie Christian ireligion, liuns. Henry Beveride (London, 1953), Bk. I., Chap. 3, Sect. 1. Henceforth, rererences to the lngtitutios will bo cited sir tinis way: I, 3, 1 .

$6_{\text {Seo Edward }}$. Jowey, Jr., Whe Knowledye of ciod in Calvin's Pheolofy (New York, I bisit), p. 221 and passim. The . phrase 1s. Dowey's. ...

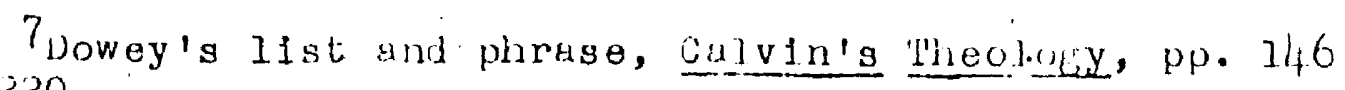
und 220 .

8 Institutos, $111,3, \times 11$. 
two aspects: (a) the instilling and implantation in men's minds of "the love of righteousness, to which we are by no means naturaliy inclined"; and (b) the prescription of "a mule which w1ll prevent us while in the pursuft of righteousness from golng astray."9 Thus the system is clearly not -primarily soterlological, but moral. As Hunter puts 1t, the essence of Calvin's teaching is "the moralisation of all Iffe through religion": "Calvin's lifelong alm and business were to re-wed religion and morallty. say that Calvin's plety was moralism.

To make some men holy is God's method of narrowing the gap. Our analysis of Calvin's thought on this point must take two forms: first, a brief statement of the steps which, Calvin maintains are followed by God in the salvation process, and, second, an analysis of the psychological technique used by calvin in describing this process.

For Caivin, the first step in the salvation process is the election of the saint before all time. Once God had chosen HIs elect, He then had to Inyent a method by which His justice could be satisfied, for it would have been immoral to let sinful man off scot-free. God's system was satisfled by the atonement: "Christ, in his death, was

9 Institutes, III, $6,11$.

'10Hunter; lieuching of Calvin, p. 248. See also Hardin Crais, Phe Enchanted Glass (New York, 1436); :p . 56-57. Craig argues that Calvin was interested prinulily in saving his people from the degenerate society of his day. 
offered to the Father as a propitiatory victim"; 11 by this means "the glory of God" was "maintained unimpaired," and. man's consclence, in the view of God's tribunal, could "be secured in peaceful rest and calin tranquility."12 With the atonement God was able to confer Chrlst's righteousness on the elect, the process being called "justification." In time, "the special election which othërwise would remain hidden in God, he [God] at length manifests by his calling."I3 'The benefits of Christ are then made avallable to man by faith, which is genorated in man by the Holy spirit. 14 Next follows sanctiflcation, which in the Institutes is prosented somewhat ambiguously. It is interpreted in one place as man's reciprocal action: "Ever since Christ purified us... it would 111 become us to be defiled with new pollution."15 In another place Calvin argues that "we are created in Christ Jesus with good works, which God hath prepared . . all the fruits of good works are originully und immediutely from God."16 At any rate, after "calilne," man is free from the dominion of $\sin$ and the Devil. 17

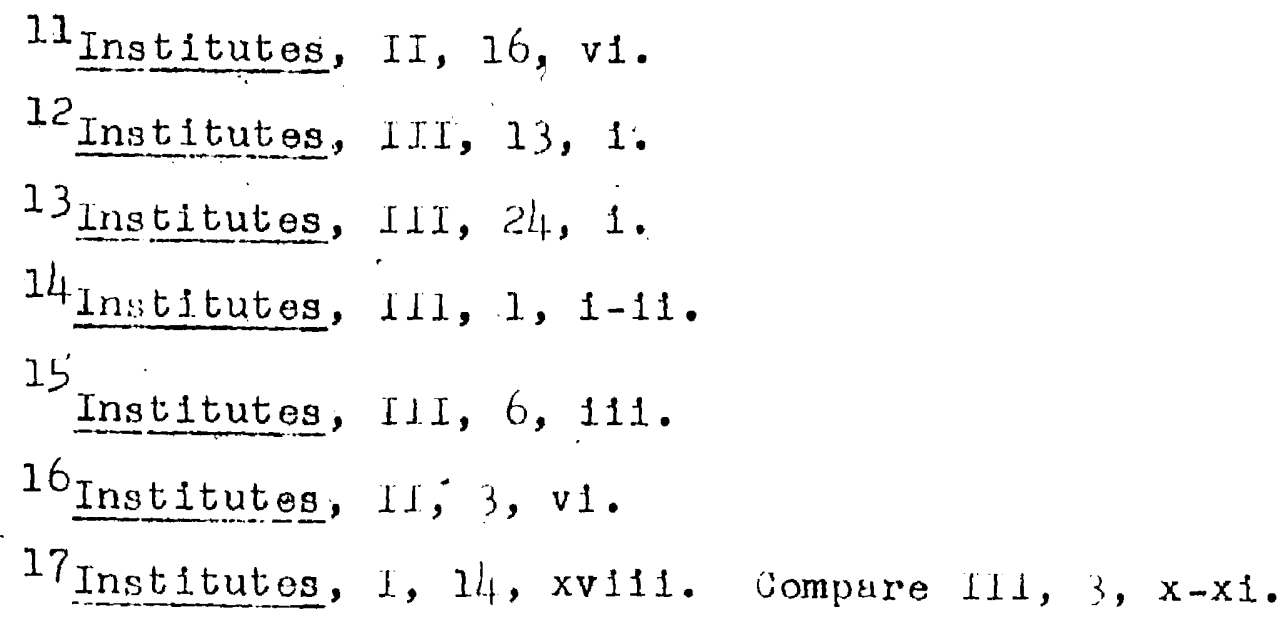


This is one side of the situation which Calvin describes. In the bald outline form presented here, the theology may seem nelther attractive nor convincing. But if we go over. the same ground in an attempt to get at Calvin's psychological approach, we may become more appreciative. A key to the approach is a passage which occurs parly in the Institutes: "Until men feel that they owe overything to God, that they are cherished by his paternal care, and that he is the author of all their blessings, so that naught is to be looked for away from him, thoy will never submit to him in voluntary obedience."18 Man's nature being what it is, he will nover desire to become righteous until he knows that he hes been elected. Or, as Calvin puts it elsewhere: ". . no man will ever' reverence God that does not trust that God is propitious to him; no man will ever get himself to observe the Law who is not persuaded that his services are pleasing to. God."19 There is, in this view, a necessury connection between election and holiness.

If we go back to Browning's poem, we see that it does not represent calvinism. If it be said that a man wastes his time by trylnf; to make his life holy when he inay be reprobutod, this is, to Calvin, "the most impudent fulsohood. from whence can any. such study come but from alection?"20

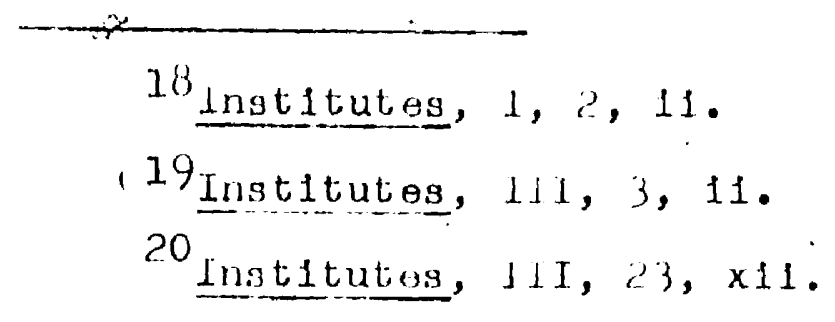


On the other hand, Calvin's system does not permit pride: "We differ not at al . . the one from the other but that it pleased god to gather unto hym selfe those whom he wolde."2l Taking another approach, Calvin maintains;. "If the end of election is holiness of life, it ought to arouse and stimulate us strenuously to äspire to' 1 , instead of serving as a pretext for sloth."22

What of the assurance of salvation, which Calvin felt was absolutely necessary? Falth, according to Calvin, cannot be apprehended "without at the same time apprehending sanctification. ... Christ.. justifies no man without also sarctifying him."23 Therefore, we know we are elected "when we receave in obedyence of fayth the doctrine of god, and rest upd his promises, accepting the offer whiche he hath made to hold us for his chyldren."? 4 As this passage may suggest, Calvin did not demend that his hearers and readers make agonizing reappraisals periodically to determine the state of their souls, as did some other Reformed theologians. On the contrary, when we find him mentioning the matter at all, It is in a far different spirit: ". . everyone ought to regard his calling as a token of his election. Farther,

\footnotetext{
sig. Ditivo Godly and Notable Serinons . . YLondon, c.1575), $2 \dot{2}^{\text {Institutes, }}$ III, 23, xi1. 23 Institutés, III, 16,' 1. 24 Tvvo GodIy Sermons, sig. Dviiir and $v$.
} 
although we cannot judge with the same certainty as to another's election, yet we must always in the judgment of charIty conclude that all that are called are called to salvation 25 There is no demand here for a soul-searching designed to achieve a full proof of election: Calvin's intention is simply to offer consolation.

On the related question of reprobation Calvin. is much less frightening than the modern reader might suppose. The doctrine itself he states without any ambigulty: "All are not created on equal terms, but some are preordained to eternal Iife, others to eternal dannation; and, accordingly, as each has been created for one or other of these ends, we say that he is predestined to life or death." 26 calvin is equally clear in denying that this is unjust or purposeless. "The refusal of the reprobate to obey the word of God when manifested to. them, will be properly ascribed to the malice and -depravity of their hearts; provided it be at the saune time added, that they.were adjudged to this depravity because they were raised up by the just but inscrutable judgment of

25 Comnentary on the Epistle of Paul the Apostle to the Corinthians, trans. John Pringle (E) Tnburgh, 181, Note also Calvin's observation: "fayth is to us . . . an infallible mark, that god rekeneth us for his chyldren. . ." l'vvo Godly Sermons, sig. Evi. Further, "linere are two reasons that show that it is more than necessary for tnis doctrine of predestination to be preached . . one is tirat God is to be magnified as $\mathrm{He}$ deserves; the second is that we are to be made certain of our salvation, to invoke Hin as our father in full freedom." Sermon on Ephesians I. 3-6, quoted by Leroy Nixon, John Calvin, Expository Preacher (Grand Rapids, wichigan, 1950), p. 87. 26 Institutes, III, $21, \mathrm{v}$. : 
God to show forth his glory by their condemnation."27 Not $s^{\circ}$ only does God, by depriving them of saving grace, leave them to their naturally depraved state; he also excltes their wills toward evil. 28

But Calvin does not soem to have had a thought of reprobation when dealing with individuals and, according to Hunter, never named anyone as doomed. Instead he urged all ministers to press the claims of God on all men as if all could be saved.29 He wrote in 1555, "I know well enough that we ought to be humble and modest in the treatment of this profound mystery - - Lof election and reprobation; my] only object is to subdue the pride of the human spirit, and to teach it to reverence in all fear and humility the majesty of God."30 In his preaching, therefore, calvin did not terrify his hearers, because he treated reprobation with reticence and with emphasis on God's honor and erace. 31 Several close students of Calvin's thought have even argued that Calvin's preaching did not encourage--even

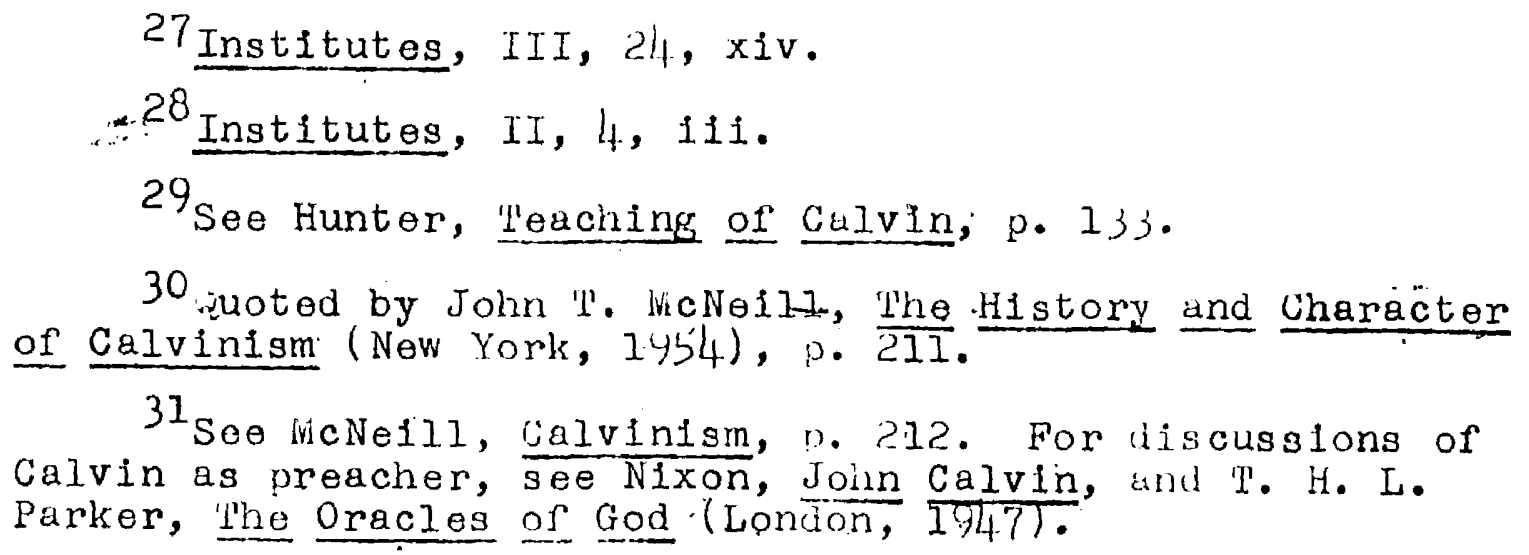


unintentionally--preoccupation with one's spiritual health. 32 Calvin's teaching instead seems to have inspired, more than anything else, worsh1p of God's gracious quality.

Let us take a closer look at Calvin's theory and pract1ce of preaching. Such an examination is necessary because Perry M11ler, 33 s. E. Norlson, 34 and others have relied too exclusively on the Institutes in forming their concept of Calvinism, which they then compare with their concept of seventeenth-century New England theology--as revealed in sermons.

Calvin's "Summary of Doctrine concerning the Ministry of the Word and the Sacraments"35 is his fullest discussion of his concept of preaching. For calvin, the ministry operates on a sacramental basis. 'the external preaching of the word of God by the minister to the people is matched by the internal communication "to the souls of all who will" 36 by the Holy Spirit of what the Word proclaims: Christ. Preaching is very much like the sacraments of Baptism and the Supper of the Lord, both of which also conmunicate

32 E. Doumerifue, Jean Calvin: Les Hommes et Les Choses de son Temps (Lausanne, I9I0), IV, $399 ;$ E. TroeItsch, MCaIvin and Calvinism," Hibbert Journal, VIII (1909), 108."

33 Especially in the New England ind: The Seventeenth Century (Cambridge, viss., 1954; rirsted., 1939), hereafter cited as Seventeenth Century.

34, Phe Puritan Pronaos (New York, Iy36).

35 In Calvin: Theological Treatises, ed. J. K. S. Reid ( Hiladelpha, 145\%).

36 reatises, p. 173. 
Christ. In the one instance falth is the means by which the elect, recelve grace; in the others water and bread and wino are the means of grace.

A statement in the Institutes should help to prepare us for the sermons themselves. In his discussion of reprobation Calvin warns future preachers to beware of how they deal with the doctrine. "Were any to address the people thus: If you do not belleve, the reason is, because God has already, doomed you to destruction: he would not only encourage sloth, but also give countenance to wlckedness. Were any to give utterance to the sentinent in the future tenge, and say, that those who hear will not believe because they are reprobates, It were imprecation rather than doctrine.137

Calvin's own practice was to avoid preaching reprobation almost entirely, dwelling instead on God's love as revealed by his election of the saints. This theme is central in all of the sermons which I have read. For example, in Ihirteen Semnons.". Entreating of the Free kilection in Iacob and of reprobation in Esau ${ }^{38}$ Calvin identifles his hearers with Jucob, who was chosen by God not for any personal merits but merely to demongtrate his mercy. 'Phroughout line series of sermons calvin seems to take for granted that his hearers are saints, God's chosen, and evon appoars to offer his hearers assurance of thelr election: "let vs. . . content

\footnotetext{
37 Ingtitutes, III, $23, \mathrm{xiv}$. ${ }^{38}$ I have us ed the vinglish ininsitition of $25 \% 9$.
} 
our selues with the holy scripture. and when there 1 s any cause of inquiring after God, if we will have him for our maister, let vs come to the holy scripture. . Ifor] it pronounceth cleerly and manffestly that God hath chosen vs In Iesus" Chrlst before the creation of the worlde, according to h1s good pleasure, the which he hath purposed in himselfe."39 How grateful should we elect then bed

In a sermon "On Enjoying Church Ordinances, "40 calvin makes no mention of predestination gt all; the sermon, however, has much the same theme as do. the thirteen on reprobation and election: the blessings of God which are enjoyed by calvin's hearers. This time the particular blessing is the privilege of having the means of salvation, especially the sacraments, available in their true form.

In the first of Tvvo Godly Sermons . .,4l Calvin's emphasis is on doing honor to the God who has saved his hearers, again the assumption being that his hearers are the elect: ". - he hath brought us the saluation and hathe further cauled us to make us partakers therof"; ${ }^{42}$ ". . god elected us beyng not moued therunto throughe our desertes, afore we coulde haue layd before hym any thyng at al

39 Follos 30 and 31. 40 In Four Sermons on Important Practical jubjects (Edinbureh, 1851 ).

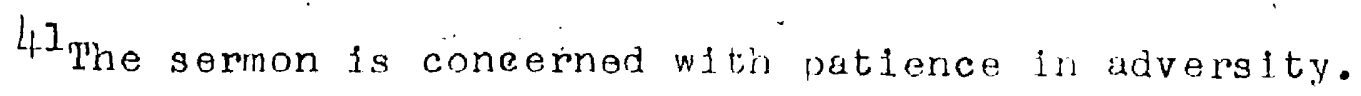
$42_{\text {SIE. Bilit. }}$. 
. 143 This positive approach to election is always the one. which Calvin takes.

One needs to remember that for findine what Calvin regarded as fyndamental Christian doctrine the best source is not his dogmatic textbook the Institutes, which was designed for the preparation of candidates for the ministry, 44 but the catechisms and confessions which Calvin prepared for the laity, and, of course, his sermons. H. D. Foster has argued that since the doctrine of double predestination is omitted from the definitive edition of the Geneva Catechism and from "the four creeds from Calvin's hand," it is clear that he believed this doctrine not to be fundanental and regurded it as quite unnecessary in a church's symbol of faith. 4.5 Although this may be an overstatement, it is significant that the record shows Calvin to have recelved a converted Anabaptist Into the Church although the latter was unwilling to accept the doctrine of predestination. 46 Hunter's position seems to be correct: Calvin regarded predestination as a "part of the substance of the faith but would not force it at bayonet's

${ }^{43}$ Sig. Cvir. See also sies. Dilitv and Diiiilv.

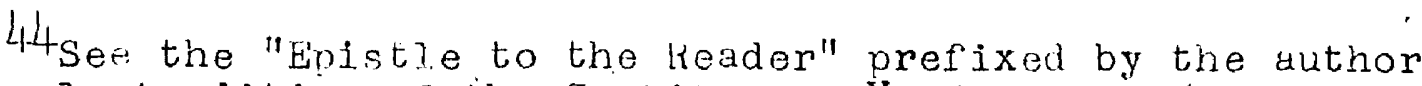
to the last edition of the Institutes, Vol. I, p: 25. $4^{45}$ Collected pavers (Hanover, N. H., 1924), p. 111. Compare. Wililston waiker, John Calvin (New York, iyub), pp. 41646 Hunter, teaching of Cálvin, p. yb. 
point upon anyone reluctant to accept 1 t. 147

Foster seems to be on firmer ground when he states that Calvin never held that grace is irresistible and that he regarded as nonessential such points as whether Christ" died for all or only the elect and whether one can fall from grace. 48 It is true that in the Institutes Calvin states that "no man approaches God unless prevlously Influenced from above," and that God's "mercy is offered to all who desire 1t and Implore 1t, and this none do save those whom he has enlightened." 49 But this is not the orthodox doctrine of Ifresistible grace. On the other hand, we find Calvin maintaining in a sermon that "a man shall finde many, who through contept \& Ingratitude wil shut against themselves the gate of galuation \& relect all the graces of God. 150 Although the 1dea of resisting grace is not central to Calvin's thought, one does not have to go through many sermons to find a sentiment such as this: "It is true that faith is the gift from the Splrit of God alone, but nevertheless, we must not repulse Him when he speaks so sweetly to us, for He invites us, and only asks that we be uniled to Him, to rejolce in the plentitude of blessinis which He has

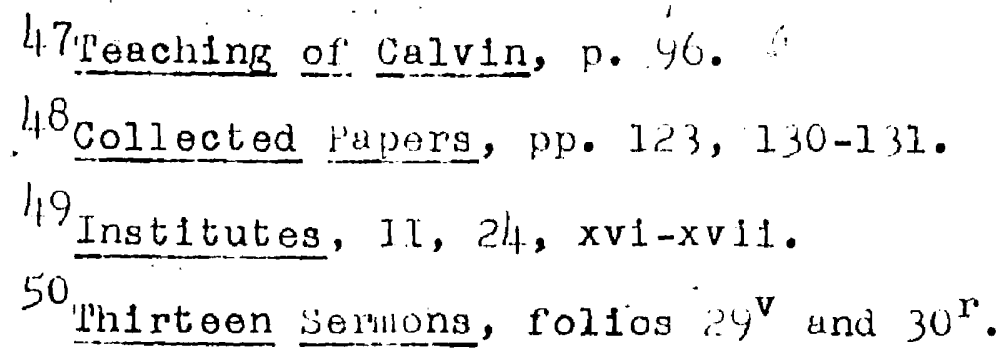


put in our Lord Jesus Christ." 51

These passages are significant for their resemblance to expressions which occur in the writings of the so-called nonCalvinistic covenant theologians.52 If the test is to be what. Miller seems to make 1 , the "Five Points" of "Calvinism," It appears that Calvin might score as only about a fifty-percent Calvinist.

A brief look at some of the symbols of faith which Calvin elther had a hand in or agreed to may well suggest what was Calvin's Calvinism on the theology of salvation. 'Three documents are convenfent and useful: the Genevan Confession of 1536, the Catechism of the Church of Geneva (1545), and the French Confession of Faith (1550).53

The Geneva Confession, which Calvin participated in writing, does not mention election. It states that "since man is naturaliy . . depraved and destitute in himself of all the light of God, and of all righteousness . . hence he must look outside himself for the means of salvation." 54 By God's Spirit men are "regenerated into a new spiritual

${ }^{51}$ Calvin's Sernon on Luke II. 9-14, in Purker, The Oracles of God, p. 150. The sermon contains no mention of predestination.

${ }^{52}$ See Milior, Seventeenth Century; for exanple, p. 393.

53 English versions of the first two are Biven in Calvin: Theological Treatises; of the last, in 'the creeds of Christendom, ed. Philip Schaff (New York, $187 \%$ ), Vol. III.

54 Article V, Treatises, p. $2 \%$. For Calvin's role in tts writing, see preatises, p. 25. 
nature." Thus man's "will is rendered conformable to God's will, to follow in his way and to seek what is pleasing to him," and then "we are made capable and able to do good works and not otherwise."55 Those who contend that calvin is basically a moralist rather than a dogmatist can find good anmunition here.

The Catechism of the Church of Geneva is interesting in that, while it does not mention election, it implies that man has certain abilities, seemingly independent of God's grace. In answer to the question "What is the right way of honoring God?" the catechumen is to answer: "To put all our trust in him; to study to serve him all our life, by obeying his will; to call upon him, whenever any need impels us, seoking in him. salvation and whatever good things can be desired..." 56 The first draft of the French Confession was written by Calvin. If we could be sure that Calvin was responsible for Articles XII and XXI, we should have a better case for beIleving that Calvin attached more importance to the doctrines of double election and the perseverance of the saints than Hunter and Foster have maintained. Article XII states, in part, "We believe that from this corruption and general condemnation in which all men are olunged, God, according to his

$$
\begin{aligned}
& 55 \text { Article v, Preatises, p. } 28 \text {. } \\
& 56 \text { Treatises, pi. } 91-92 \text {. It is of course true that }
\end{aligned}
$$
Calvin says elsewhere that only the elect have the ability to honor God in the right way. But we are here examining only what the Catechism says. For a discussion of tire autiorship of the Catechism, see preatises, p. 83. 
eternal and immutable counsel, calleth those whom he hath chosen by his goodness and mercy alone in our Lord Jesus Christ, without consideration of their works, to display in them the riches of his mercy, leaving the fest in this same corruption to show in them his justice." 5 ? Here surely is double election in its strictest form.

In Article XXI we read: "Wo believe also that faith" is not given to the elect only to introduce them into the right way, but also to make them continue in 1t to the end. For as it is God who hath begun the work, he will also perfect 1t. 158 This sounds Iike the doctrines of Irresistible grace and the perseverance of the saints. But, there is also Article XIII: "We belleve that all that is necessary for our salvation was offered to us in Jesus Christ. He is given to us for our salvation... so that if we refuse him, "we renounce the mercy of the Father, in which alone we can find refuge. "59 If the "our" and the "us" of the first. sentence refer to the elect, then the last clause suggests that grace is not irresistible. If the words refer to all mankind, then Christ did not die for the elect only--a teaciing contrary to

57 Creeds of Curistendom, III, 366-367. Hor a discussion of the authorship, see Creeds, I, 439.

${ }^{58}$ Creeds, III, 371; italics inine. The italicized phrase reads in the prench, "pour les y fidre continutr."

$$
59 \text { creeds, III, } 367 .
$$


the so-called "Five Polnts of Calvinism." 60

Conclusions based on the French Confession must be conditional. If Calvin did write Articles XII and XXI, then in his last years he came to regard some doctrines included in the "Five Points" as fundamental. But surely these five adoctrines do not represent all that was most important for Calvin.

. "This survey of Calvin's teachings on salvation w1ll have been successful if it has both indicated Calvin's basic position and made less credible some current ideas concerning Calvin's thought. What we have seen should make clear the falsity of a recent historian's description of Calvinism: "God had predestinated every human being elther to salvation or to damnation, and . . no intensity of faith or integrity of conduct could alter that foreordinance."61 "Impudent falsehood!" (in Calvin's words). Nor is it accurate to say that Calvin "demanded that they [his disciples] contemplate with steady, unblinking resolution, the absolute,

${ }^{60}$ calvin's views. on whether or not Christ died only for the elect are not dogmatic. For a good discussion of the point, see John Olert, Jr., "Predestination: CaIvin and the New England Theology," unpub. Th.lvi. thesis (Union Theological Sominary, New York, 1943), pp. 13-24. Olert concludes that to Calvin a variety of opinions could be regarded $a s^{\circ}$ orthodox. The Canons of Dort contain an ambiguity similar to that observed in the French Confession. See below. 61 s. T. Bindoff, Tudor England (Harnondsworth, Eng., $1952)$, p. 226. 
Incomprehensible, and transcendent glory of God."62 For

Calvin, the true disciple would find God rather to be $a$ "guardian and protector," "fountain of all goodness," and "author of salvation." 63 ..

Continental Reformed Soterfology through the

) Time of the Synod of Dort

We shall next examine briefly the development of soteriological thought among Continental theologlans in the Reformed tradition. These include both contemporaries of Calvin and theologians of the late sixteenth and earlier seventeenth century. Since the synod of Dort marks the end of an epoch, and since most of the theologians whom Hooker cites flourished before Dort, It serves as a useful stopping place. 64

The first two theologians, whose positions we shall examIne are Wartin Bucer and Helnrich-Bullinger. Although I have not located references to Bullinger in Hooker's writings, he

62 Perry Willer, "The Marrow of Puritan Divinity," Pub. Col.. Soc. Wiass., Transactions, 1933-1937, XXXII, 248. The source of all of illier's citations from calvin here is the Institutes; the sermons are not mentioned.

163 Institutes, $I, 2,1-111$.

64 Hooker refers to most of the more important Continental reformers. I have counted elght references to Beza (only one fewer than Hooker's.references to Calvin), four references to Junius, three to Zanchius, and also references to such other 1mportant uriters as Vernigl1, Piscitor, Bucer,
and pareus. 
had a great influence in England in the sixteenth century; 65 many of the Miarian Exiles had come under his influence at Zurich 66 and continued to keep in touch with him after their return to England. The correspondence of Bullinger with Bishop Grindal (Iater Archbishop of Canterbury), Bishop Sandys (later Archbishop of York), John Foxe, and Bishops Jewel, Parkhurst, Cox, Horn, and others, reveals the high regard in which Bullinger was held in England. 67 The "Pur1tan Bishop" Hooper was especially Influenced by Bullinger. 68 Perhaps most important as vehicles of his influence were the many works of Bullinger published in ingland, 69 notably his. collection of sermons, The Decades, which enjoyed a semiofflcial status in the sixteenth-century Church of Eingland. 70 Bullinger's theology emphastzes the justifying mercy of

${ }^{65}$ See M. M. Knappen, Tudor puritanism (Chicago, 1939), p. 367 , and $L$. J. Trinterud, "The Origins of Puritanism," Church History, $\mathrm{XX}(1951), 37$.

${ }^{66}$ See Christina Garrett, The Marian Exiles (Cambridse, Eng., 1938); passim.

67 See Hastings Robins on, ed.", The Zurich Letters (Cambridge, Eng., 184.2-184.5).

${ }^{68}$ See Hooper, Later Writings, ed. Charles Nevinson (Canbridge, Eng., 1852), pp. vii-x.

${ }^{69}$ See the extensive list In rollard and hecigrave, Short-ritle Catalogue.

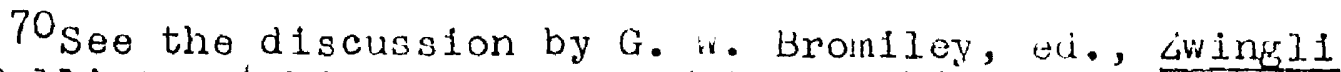
and Bullinger (Philadelphia, 1453), pp. $283-20)$. Ine Decades have been edited by thomas Harding (Cambriage, wng., 184(9-1852), in four volumes: 
God, 71 but $1 \mathrm{~s}$ vague on the question of predestination. 72 For Bullinger, "the cause of God's mercy to us-wards must of necessity be not in us, nor in any other thing beside God -. ."73 Indeed, "unless we be drawn of the heavenly father, we cannot believe, and we must be very careful, lest we . . neglect the drawing itself." Consequently, we should "despise not the grace offered, but use it whiles time present"serveth . . . "174 An Arminian would admit as much! 75 Bullinger here preaches man's inabilify, but surely not the irresiatibility of grace which, on the contrary, man should not despise. Elsowhere, Bullinger gives his hearers definite assurance that they can know they are "predestinate to life" by the "assured sign" of falth.76 But Bullinger's inconsistency is revealed by another passage, which tells us that

we must not imagine that in heaven there are laid two books, in the one whereof the names. of them are written that are to be saved, and so to be saved, as it were of necessity, that, do what they will against the word of Christ and commit never so heinous

${ }^{71}$ Especially in his 1mportant De gratia pei.

72 See otto Ritschl, Dogmengeschichte des Protestantismus, III (G8ttingen, 1926), 246-248. .

73 Decades, III, $\%$

74 pecades, III, 190.

75 See Joseph Hall's interesting Via Wedia: The Way of Peace, in Volume $X$ of his Works (Oxford, I'U37). 76 Decades, III, 187. 


\begin{abstract}
offences, they cannot possibly chose but be saved; and that in the other are contained the names of them which, do what they can and live never so holily, yet the cannot avoid everlasting damnation. Let us rather hold, that the holy gospel of Christ doth generally preach to the whole world the grace of God, the remission of sins, and life everlastIng. 77
\end{abstract}

Although the straw man that Bullinger sets up to knock down is not of course Calvinism, this statement, which seems to be theological rather than rhetorical in nature, implies that redemption is not particular, but general.

The last passage cited is significant because it indicates the original nature of Reformed preaching, before symbols of faith had so restricted the linits of man's ability that reactions such as covenant theology set in. 78 The uncertainty of Bullinger's views on predestination may be the reas on why Hooker and his fellow seventeenth-century Puritans did not make much use of his teachings. M̀artin Bucer (or Butzer), regius profes'sor of divinity at Cambridge from 1549 to 1551, the year of his death, was thoroughly in agreement on theological matters with Calvin, whose views on predestination he anticipated. 79 , since their views were nearly identical, it becomes difificult to trace

\footnotetext{
77 Decades, III, $32-33$

78 For covenant theology, see Chapter IV below.

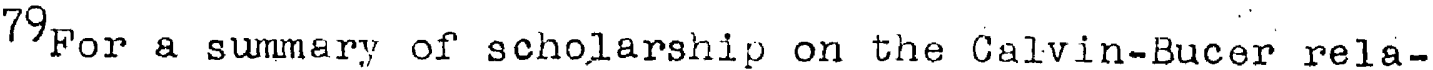
tionship, see Wilhelm Pauck, The Heritage of the Reformation (Glencoe, III.," and Boston, 1950), pn. 77-79, 9 ?
} 
their comparative influence. Iike many Reformed theologians. who, though basically independent of Calvin, had views on. predestination similar to his, Bucer contributed to the increasing popularity of Reformed theology. But gradually Calvin's influence became more important than the influence of the other. Reformed theologians, such as Bucer. ${ }^{80}$. However, an important and perihaps influential difference in emphasis has been observed in Bucer's teachings: while Calvin thought of religion primarily as related to God, Bucer thought of it primarily as related to man's salvation. 81 . The latter approach is much more that of Puritan preachers than is Calvin's.

As John T. McNe1li has observed, Bullinger and Bucer were not Calvin's opponents, but his co-workers. 82 Although the same can probably be sald of the Reformed theologians writing after Calvin, the divisions which Ritschl has used are helpful. According to him, one group of the Reformed were predominantly indepondent of Calvin: Ursinus, Peter

${ }^{80}$ See Ritschl, Dogmengeschichte, III, 283-289.

${ }^{81}$ See Pauck, Heritage of the Reformation, p. 91; and compare Ritschl, Dogmengeschichte, III, 245, and Roland $\mathrm{H}$. Baintion, The Reformation of the Sixteenth Century (Boston, 1952), p. 117. The Puritan Whitaker in 1595 noted that English theology of his time was much indebted to Bucer. See Constantin Hopf, martin Bucer and the English Reformation (Oxford, 1946), $\overline{\text { p. } 260 .}$

82 History and Character of Calvinism, p. 310. Also among CaIvin's co-workers was John a Lasco or Lasli, who lived for a time in London. See Charles Beard, The Reformation (London, 1897), pp. 182-183. 
Martyr Vermigli, Musculus, Keckermann, Alsted, and others. A second group consists of those who were predominantly followers of Calvin: Zanchius, Piscator, Bucanus, Beza, Perkins, Junius, Gomarus, Twisse, and others. ${ }^{83}$. It is perhaps signiflcant that while Alsted, Keckermann, and Ursinus were popular writers in seventeenth-century New England, 84 no references to their writings appear in Hooker's works to my knowledge, and only three references to other "non-Calvinists"; on the other hand, references to Calvin's followers, the high or strict "Calvinists," are much more common. 85

\$ Of the writers who regarded themselves as followers of Calvin, Theodore Beza, frequently referred to by Hooker, is in many ways the most important. First as Calvin's co-worker and then as his successor, Beza benefitted much in terms of prestige from his identification with Calvin. But his teachings are different from Calvin's in an important way. While for Calvin predestination was primarily a practical matter, for Beza 1t was an 1ssue to be treated with strict logic.

\section{Ritschl, Dogmengeschichte, III, passim.}

84 See Miller, Seventeenth Century, pp. 96, 102-103, and passim.

85 Hooker refers to two theologlans who were not followers of Calvin. He refers twice to Peter Martyr Vermigli, who spent several years in England ( see Alexander Gordon, s. v. "Vermigl1," DNB). Vermigli followed Bullinger in his concept of predestination. See Ritschl, Dogmengeschichte, I1I, 269. I have also observed one reference to wisculus, whose interpretation of predestination agrees in many ways with Bucer's. See Ritschl, Dogmengeschichte, III, $24 \%$ 
Calvin's somewhat undeveloped theory of predestination becomes In Beza's writings supralapsarianism: even the fall of Adam was divinely ordained. "Predestination," says Beza, "is an eternal and Immutable decree whereby he [God] determined to be glorified by saving some in Christ by mere grace, and by damning others in Adam and by his own just judgment. "86 This extension of Calvinism to supralapsarianism marks the beginning of a new stage in the development of Reformed thought: "Protestant Scholasticism." 87 we shall look at this a ittle later.

Beza's theology differs from Calvin's in another way significant" for us. Whereas for Calvin the test of election was faith in Christ, for Beza the test was the perfornance of.good works through the sanctification which followed offectual calling. ${ }^{88}$, Although both tests were used by puritan

86 Quoted by E. F. Karl MUller, s. v. "Predestination," Schaff-Herzog Encyclopedia of Religlous Knowledge. See also Eugene Cholsy, s. V. "Beza, " schaff-Herzog. WIIIIam Cunningham, who defends. Beza as a follower of CaIvin, writes that "the points of alleged difference between them in matters of doctrine, respect chiefly topics on which Calvin was not led to give any very formal or explicit deliverances, because they were not at the time subjects of discussion, or indeed even present to his thoughts."-The Reformers and the "lheology of the Reformation (Ed inburgh, 1866), p. 341.

87 See Charles Beard, Reformation, pp. 262-249, and Arthur C. McGiffert, Protestant Thought Before Kant (New York, 1911), pp. 141-154.

88 Ernest Troeltsch, The Social Teachings of the Christian Churches (Lond on, 194. 
preachers and writers, 89 the greater frequency with which Beza's test is invoked by Hooker and others makes Beza's contribution to Reformed soteriology significant.

Perry Miller has suggested that New England preachers read more widely in the writings of theologians following Calvin than in the writings of the great Genevan reformer himself. Miller goes on to say, "Even if the specific doctrines of Calvinism were unchanged at the time of the migration to New England, they were already removed from pure Calvinism by the difference of tone." 90 Although Miller unfortunately falls to define "Calvint.sm" here.or elsewhere, It is clear that by 1630 there had been major changes in Rer formed thinking since the days of Calvin--far more significant than the change of tone that lviller has observed.. The debates anong the Reformed and between the Reformed theologlans and other Protestants did much to narrow the limits of orthodoxy. "Bezaism" won victory after victory over Bullingerism and less strict varieties of Reformed thought. Severa. of the writers to whom Hooker refers vere important proponents of this stricter brand of theology: David Pareus,

\footnotetext{
8

${ }^{89}$ See the interesting list compiled by Knappen, Tudor Puritanism, p. 394. For Caivin "Nous ne pouvons pas nous asseurer de notre salut que par la foy". . ."-Congregation sur l'election éternelle, quoted by Doumergue, Jean CaIvin, IV, 397. तccording to iroeltsch, Puritanism developed a system of self-examination into good worlks as a'sign of election. See Social Teachings, II, 680, and below.

90 Seventeenth Century, p. 97.
} 
author of Orthodoxus Calvinus; 91 Junius, who attempted by means of some very nice distinctions to set up a moderate position between supra - and infralapsarian1sm; 92 and

Zanchius, who developed to a new position of importance the idea of the perseverance of the saints. 93 . Reformed orthodoxy reached such a point of refinement that Calvin himself "would probably have made a difficulty about adopting precise and definite deliverances on some points concerning the truth of which the great calvinistic divines of the seventeenth century had no hesitation." 94 This is the significant change" in the Reformed theology.

The arguments among the Infralapsarians, the sublapsarlans, the supralapsarians, and the semi-supralapsarians on the order of the divine decrees, and other similar controversies gradualiy split the Reformed party into two groups, the "High Calvinists" or Bezaists, a good example of whom is William Perkins, 95 and the low or "Liberai Galvinists" or

${ }^{91}$ See Ṕlerre Bayle, s. v. "Pareus," Dictionnaire Historique et Critique.

92 See Ritschl, Dogmengeschichte, III, 311. ${ }^{93}$ See Ritschl, Dogmengeschichte, III, 288.

94 Cunningham, The Reformers, p. 4.12 .

95 Perkins is discussed later. Ritschl relates him to other Reformed writers in Dogmengeschichte, III, 300-303. 
Arminians.96 other than causing a split among the Reformed, "theologisch fructbar aber ist diese scholastik eigentlich nur in Spltzfindigkeiten gewesen," 97 as Ritschl nicely puts 1t. Its total effect was the crystallizing of the Reformed theology, for the split brought about the synod of Dort and its Canons.

A useful method of showing the development of the Reformed theology is to examine the history of its symbols of belief. After the creeds of Calvin which have already been discussed, one of the most important is the Belgic Confession (1561, revised 1619), called by schaff "the best symbollc statement of the Calvinistic system of doctrine, with the exception of the Westminster Confession."98 The Belgic Confession does not teach a limited atonement, irresistible grace, the perseverance of the saints, or a decree of reprobation, although it has a clear doctrine of election:

We belleve that all the posterity of Adam, being - . fallen into perdition and ruin by the sin of our first parents, God then did manifest himself such as he is: that is to say, merciful and just: merciful, since he delivers and preserves from this perdition all whom he, in his leternal and

\section{Foster defends the use of the term "Iiberal calvin-} ists" in his paper "Liberal Calvinisin and the synod of Dort," published in his Collected Papers. On the relationship of Calvin to Beza and supralapsarianism, see Cunningham, The Reformers, pp. $362-364$.

97 Ritschl, Dogmengeschichte, III, 314 .

98 Schaff, Croeds, I, 506. l'he Confession is included in Volume III of Creeds. 
unchangeable council, of mere goodness hath elected. In Christ Jesus our Lord, without any respect to their works: just, in leaving others in the fall and perdftion wherein they have involved themselves. 99

The Heidelburg Catechlsm (1563), like the Belgic Confession approved by the Synod of port, 100 is even less outspoken on the "Five Points." Nothing is said here of a linited atonement, a decree of absolute reprobation, irresistible grace, or the perseverance of the saints. 101 Even the idea of election 'ltself' is only sugesested in phrases such as that of question 20, that only those are saved who "by true faith are ingrafted into him [Christ] and receive his benefits,"102 or more particularly that of Question 54: ". - out of the whole human race, from the beginning of the world, the son of God, by his Spirdt and Word, gathers, defends, and preserves for himself unto everlasting life, a chosen communion in the unity of the true faith. . . "103

At Dort many of the doctrines which had previously been at most the views of individual theologians became binding

99Article XVI, quoted by schaff, Creeds, III, 401.

100 Schaff, Creeds, I, 506-507, 549. Schaff includes the Catechism in Volume III of Creeds.

${ }^{101}$ See the interesting discussion in the percentenary Edition of The Heldelburg Gatechism

102 Schaff, Creeds, III, 313.

103 Schaff, Creeds, III, 325 . 
upon the minfsters of the Reformed Church in France, and were recelved with respect elsewhere: clergymen who opposed the doctrines of the Canons of Dort were deposed in the Netherlands. 104 Weber speaks of the disappearance in Calvinism of the God of the New Testament, whose "place has been taken by a transcendent being, beyond the reach of human understanding, who with his quite incomprehengible decrees has decided the fate of every individual and regulated the tiniest details of the cosmos from eternity." $105 \mathrm{He}$ speaks of the religion not of Calvin but of Dort.

Dort is of particular interest for its connections with England. Five Englishmen--two bishops, the King's chaplain, a professor, and Joseph Hall--attended the meeting. Their presence indicates that" as late as 1619 the Churoh of England was regarded officialiy as part of the body of the Reformed Church. Further, Dort had a part in the process of shaping - English Reformed theology, which was to be crystallized in the Westminster Confession. 106

The Canons of Dort are restricted to the five points of

104 Schaff, Creeds, I, 514.

105 Wax Weber, The Protestant Ethic and the Spirit of Capitalism (London, 19301, pp..103-104. In this connection the treatise of the Reformed theologian Tossanus on Providence (1597) is of interest. Here it is maintained that God's prov dence relates to lice, ants, bees, silkworms and spiders, not.just to man. See iitschl, Dogmenceschichte, III, $289-290$.

${ }^{106}$ See Schaff, Creeds; I, 7760-761, 769. 
the so-called Calvinistic system. 107 This very fact makes clear just how prominent a part these polnts had come to take in Reformed theology. The basic teachings of the canons, which are very full, may be set forth briefly.

(1) Predestination. All men by justice merit punishment for their part in the sin of Adam, but God provides mercy for some through Christ. The elect, "though by nature nefther better nor more deserving than others . . God has decreed to give to christ to be saved by him." The elect are called by the ministry of the word to faith in Christ, which faith is God's gift and "proceeds from God's eternal decree." Those who do not believe are the reprobate; God has decreed that they should be left to their just condemnation, for "the cause or guilt of this unbelief.. Is nowise in God, but in man himself." 108

(2) Limited atonement..." "It was the will of God, that Christ by the blood of the cross . . should effectually redeem out of every people, tribe, nation, and language, all those, and those only, who were from eternity chosen to salvation, and given to him by the Fiather... This purpose proceeding irom everlasting love towards the elect, has from the beginning of the world to this day, been powerfully accomplished . . . "109

107They are printed in Schaff, Creeds, III, 561-597. 108 Schaff, Creeds, III, 581-582. ${ }^{109}$ Schaff, Creeds, III, 587. 
(3) Total depravity. Man is totally depraved: unable to perform any saving good; unable to reform.

(4) Irresistible grace. Regeneration "is nowise effected merely by the external preaching of the gospel, by moral suasion, or such mode of operation that, after God has performed his part, it still remains in the power of man to be regenerated or not, to be converted or to continue unconverted; but it is evidently a supernatural work, most powerful, and at the same time most delightful, astonishing, mysterious, and Ineffable; not inferior in efficacy to creation or the resurrection from the dead... so that all in whose hearts God works in this marvellous manner are certainly, infallibly, and effectually regenerated, and do actually believe." 110

(5) Perseverance of the saints. Whom God calls to salvation, he confirms and preserves to the end. These have assurance of salvation according to the measure of their faith. "This certainty of perseverance. . should serve as an incentive to the serious and constant practic $\theta$ of Gratitude and good works . . . "111

Although these were the doctrines adopted, the objections of the "Remonstrants" or Arminians were addressed to even stricter doctrines, especially supralapsarianism,

${ }^{110}$ Schaff, Creeds, III, 589-590.
$11 I_{\text {Schaff's abridgment, Creeds, }}$ I, 523. 
which had advocates among the leaders of the "Defendants" dr High Calvinists. That the Arminian objections were denied J.s perhaps more significant than that the above positive articles were approved. The party of Gomarus, the leading supralapsarian, won the dispute, although his views were not indeed adopted. To be stricter than the Canons was permissible; to be less strict was heresy. 112

The Canons of Dort, according to Schaff, "prepared the way for a dry scholasticism which runs into subtle abstractions, and resolves the living soul of divinity into a skeleton of formulas and distinctions." It "consolidated orthodoxy at the expense of freedom" and sanctioned "a narrow confessionalism."113. It also marked the end of the formative period of the Reformed theology.

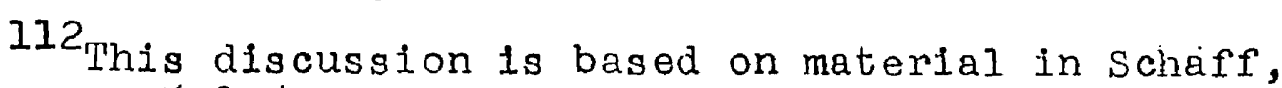
Creeds, I, 509-517, though Schaff's interpretation is rather different from the one presented here. Note also Foster's interpretation, in collected papers, $p$. 143, that the source of the argument which led to Dort was personal and political, not doctrinal.

113 Schaff, Creods, I, 515. See also Moffut, "Influence of Calvin," p. 163. 
CHAPTER II

THE PURITAN BACKGROUND OF HOOKEุR'S THOUGHT

Our study of Puritanism will begin with a brief survey of theology. In England during the period roughly from 1550 to 1620. This will be followed by an examination of the special characteristics of Puritantsm as they relate to Hooker's thought on conversion, with special attention to a discussion of Puritan 1deas on preaching. Next will follow an analysis of the teachings of some important Puritans from Hooper to Preston. After a brief examination of some Anglican views of conversion for purposes of comparison, we shall look at the English Reformed symbols of faith of the period: the Thirty-Nine Articles, the Lambeth Articles, and the Westminster Confession.

The History of the Reformed Theology in ingland, $1550-1620$

Although English theology had wavered from Roman Catholicism to Lutheranism to a semi-Reformed position during the period from 1527 to 1547 , from then on until sometime after 1600 it was closely related to the Reformed theology 
except during the brief Marian reaction. The relationship of the Church of England to the Reformed Church began in Edward's reign: Cranmer, Latimer, and Hooper were all in fluenced by the Reformed theologians of the Continent, 1 and with the return of the Protestant clergy from exile in the Reformed cities after 1558, the victory of the Reformed theology in the teaching of the English church was, for the time, sealed. ${ }^{2}$ I. J. Trinterud has contended strongly that since only a few exiles went to Geneva and none of these gained power on returning to England, the Rhinelanders' influence was much greater than Calvin's. 3 But although this may be true of the early days of Elizabeth's reign, later Calvin came to have greater influence. The statement of W. W. Southgate seems nearer to the truth. His position is that the Anglican Church from the time of Parker to the end of the sixteenth century was "Calvinistic," though the Church also looked to other Continental reformers. 4 One of the peculiaritles of the Elizabethan church is

${ }^{1}$ For Cranmer, see C. H. Smyth, Cranmer \& the Reforma-

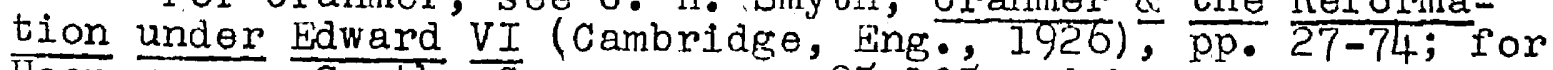
Hooper, see Smyth, Cranmer, pp. 95-105, and below; for Latimer, see A. G. Chester, Hugh Latimer (Philadelphia, 1954), pp. 167-168, 192-193, and passim.

Wilhelm Pauck, Das Reich Gottes auf Erden (Berlin and Leipzie, 1928), p. III. $45 f f$.

3 "The Origins of Puritanism," Church History, XX (1951),

4"The Marian ixiles and the Influence of John Calvin," in R. L. Schugler and H. Ausubel, eds., The haking of English History (New York, 1952), ?. 176. 
that it was not primarily concerned with metaphysics or theological doctrines as such:5 only two Elizabethan works can claim to be theological treatises, one by Dudley Fenner, one by William Perking. 6 A possible explanation is that the multitude of treatises by Continental Reformed writers published in England (in the original Latin or in English versions) satisfied the need. The Short-Title Catalogue has extensive listings under the names of, for example, Calvin, Beza, and Piscator. 7

Many seats of learning during Elizabeth's reign were filled by "High Calvinists," such as William Whitaker (15471595), regius professor of divinity at Cambridge. 8 In one of the great religious disputes of the period, the Puritan, Cartwright was opposed by an equaliy orthodox follower of Calvin, John Whitgift (c.1530-1604), later Archbishop of Canterbury. 9 Calvin's Catechism was ordered to be used at Oxford and Cambridge in 1587, and in 1581 Cambridge officially acknowledged preference for Calvin and Beza to any

5 The observation is A. L. Rowse's. See his The England. of Elizabeth (New York, 1951), p. 480.

6 Fenner, Sacra Theologia (1585); Perkins, Armillia aurea (1590) or A golden Chaine (1600).

7 In the sixteenth century alone there were, according to the Short-P1tle Catalogue, seventy-four items by Calvin, fifty-nine by $\overline{B e z a}$, and seventeen by Piscator.

8 John Dowden, Outlines of the History of the Theological Literature of the Church of England (London, 1897), p. 65 .

9 Rowse, England of Elizabetin, n. 4.69. 
other men since the Apostles $d^{10}$ The treatise of William

Perkins (1558-1602) entitled The Reformed Catholike. (1598)

supports the Church of England on the basis of Perkins's

"High Calvinism." He was so well regarded in his time that after 'his death King James' officially appointed another theologian to defend Perkins from attack by Roman Catholics. 11

Until the 1590 's no real opposition appeared to challenge the predestinarianism of both Anglicans and puritans. Then an Arminian, Peter Baro, managed to obtain some support for his views while serving as a professor of divinity at Cambridge, but he was soon silenced.12 About the same time the very strict, predestinarian Lambeth Articles, discussed below, were signed by Archbishop Whitgift, the Bishop of London, and other high officials. Although triey did not be come a public act, Whitgift announced that they were to be regarded as corresponding to the official doctrine of the

${ }^{10}$ Philip Schaff, ed., The Creeds of Christendom (Now York, 1877)., I, 603." Thirty-five editions of the English Bible published between $157 /$ and 1615 contain between the Old and New Testaments a "Calvinistic" Catechism, according to Douglas Campbell. Most of these Bibles were from the press of the royal printer. See Campbell, the Purttan in Holl and, England, and America (New York and London, 1899), II, $148-149$.

${ }^{11}$ Louis B. Wright, "William Perkins: Wlizabethan Apostle of 'Practical Divinity, " Huntington Library Quar-

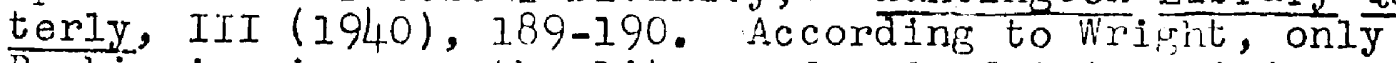
Perkins's views on the liturgy found official disfavor.

12M. M. Knappen, Tudon Puritanism (Chicago, 1939), pp. 369-370; Daniel Neal, The History of the iuritans (London, 1822), I, 455-456. 
Church of England already established. 13

Although one Puritan diarist observed ominously in $1597^{\circ}$ that "Lutheranism begins to be established," 14 as late as 1608 the Institutes were recommended at oxford as contalning the best system of divinity. 15 But despite the fact that James I and his Archbishop, Abbot, were followers of Calvin, 16 in 1616 James recommended, in letters sent to the universities for the regulation of studies, that young divinity students should rely, not on modern systems, but on the fathers and councils. According to Isaac Walton, "the advice was occasioned by the very indiscreet references made by very many Preachers out of Wir. Calvin's Doctrines concerning Predestination; Universal Redemption, the, Irresistibility of God's Grace, and of some other knotty points depending upon these; Points which many think were not but by Interpreters forc'd to be Mr. Calvin's meaning."I7 We have already observed the tightening up of the Reformed system,

${ }^{13}$ Neal, History of the Puritans, I, 455; Powel Ni. Dawley, John Whitglft and the English Reformation (Now York, 1954), p. 215 .

14Dr. Samuel Ward, in Two Puritan Diaries, ed. M. W. Knappen (Chicago, 1933), p. 126 .

15 H. Hensley Henson, puritanism in England (London, 1912), p. 80 .

16 Henson, Puritanism, pp. 42-93; w. Fraser witchell, English Pulpit Oratory (London, 1931), p. 203.

17 Waiton's life of Sanderson in Robert sanderson, XXXVI Sermons (London, I686), p. 8 . 
f which made "knotty points" central; apparently it was an Important factor in the decine of the Reformed orthodoxy from official favor within the Church of England. Engligh theology from 1620 on was to be divided into two varieties: Reformed, the Puritan theology; and Aminianism, the official Anglican theology. 18

\section{Some Characteristics of Puritanism}

Before examining the writings of some important English Reformed divines, it may be profitable to consider briefly. the peculiar characteristics of Puritanism, as distinguished from the Continental Reformed theology. The difficult task of defining Puritanism fortunately is not necessary for our purposes, but it is commonly agreed that Puritanism is more than merely "English Calvinism."19

18 The Reformed theology and the Influence of calvin did not, of course, die out in the Church of England overnight. Such notable figures as James Ussher (158I-1656), Archbishop of Armagh, and Bishop Robert Sanderson (1587-1663) were v1gorous predestinarians, at least in the earlier part of their careers. See Dowden, Outlines, p. 105. Joseph Hall, a leading figure in the Church of England during the first half of the seventeenth century, stated that it was the beIlef of the Church of Ingland that God applies the benefits of Christ's death "absolutely, certainly, and infallibly, to the elect alone... ."-Works (Oxford, 1837), X, 49.

${ }^{19}$ See, for example, J. C. Brauer, "Reflections on the Nature of English Puritanism," Church History, XXIII (1954); 99-108; Ralph Bronkema, The E's'sence of Puritanism (Goes, Holland, 1929). 
The chief distinguishing characteristic of Puritanism is doubtless anxiety concerning the state of one's soul. This anxiety gave a center and unity to the entire course of a man's actions. 20 To solve the problem, to discover one's eternal fate, one had to have a testing apparatus; and Puritan preachers provided such devices in profusion. Good works were of course the standard test, but there were others. According to John Dod, one could discover the state of his soul by testing his ability to pray; for Richard Greenham, a test was one's attitude towards sin and God; for William 'Perkins, a vague trust in God. 21 John Downame's popular book Christian Warfare (1604). was written, according to the author, to comfort those whose consciences are afflicted, by assuring them that unquestionably they are saved, and to lead them to Heaven. 22 Another standard Puritan treatise of the period, Richard Sibbes's The Brvised Reede, and Smoaking Flax (1630), is filled with observations on assurance of election; for example: "When Christs will commeth in competitio with any earthly losse or gaine, yet if the in that particular case the heart will stoope to Christ,

20R. B. Perry, Puritanism and Democracy (New York, 1944), pp. 253-255.

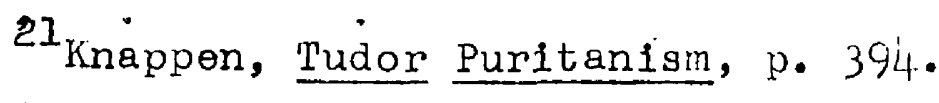
${ }^{22}$ William Haller, The Rise of Puritanism (New York, 19381, p. 155 . 
it is a true sign." 23

M. M. Knappen, editor of two important Puritan diaries, reports that they imply "a surprising amount of Arminianism" 2. tyet he quotes elsewhere the old saw that Puritans spoke like Arminians in the pulpit, and like strict predestinarians in prayer, 25 and Puritan diarles were similar to sermons in purpose and use. Further, what seems like Arminianism can be found in nearly all Reformed writings. Again observing a seeming inconsistency, Knappen declares that although "the doctrines of predestination and justification by faith clearly remove some of the strongest incentives to Christian morality . . the Puritan coolly asserted that every nerve must be strained in that cause nevertheless." 26 The explanation, not supplied by Knappen, is, as we shall see, that while fatalism is the logical outcome of predestinarianism, "on account of the idea of proof the psychological result was precisely the opposite, "27 for

23 Fourth edition (London, 1632), p. 279. William Ames lists as one of the tasks of the preacher in consoling: ". In consolation, markes are profitably joyned, by which the conscience of a man may be assured that such a benefit pertaines to him.. . "-The Marrow of Sacred Divinity (London, I643), p. 159. Se日 also Ames, Conscience. with $\frac{\text { the }}{\text { pp. }}$ Power and Cases thereof (London, 1643), Bk. II,

24 Knappen, Diaries, p. 15.

25 Knappen presents a version of the saying in Tudor Puritanism, p. 392 .

26 Tudor Puritanism, pp. $34.1-342$

27 Max Weber, The Protestant Ethic (London, 1930), p. 232. 
one had to prove to himself and to other "saints" by his Puritan morality that he was of the elect.

The magnum desideratum of Puritanism was, according to Hugh Peter, a collection and compilation of data to be used for the scientific analysis of regeneration: ". . the Experiments Ministers and others have in several cases of Conversion, and the cases of Desertion, with the quieting of souls, and means thereunto, with a probatum est, the names of the parties concealed; which if everie able Christian would write, and keep by him, and print, how might Satin's Methods bee discovered, and manie souls comforted?"28 With such an apparatus, true conversion could be exactly determined. Peter's proposal shows the great importance that "proof" came to havè in: the Puritan varlety of Reformed thought.

But in spite of all the Puritan concern with proof, there is considerable evidence that predestinarianism did result at times in fatalism. At the. Hampton Court Conference (1604), the Bishop of London reported to King James that many people were neglecting holiness and depending on predestination, saying, "If I shall be saved, I shall be saved."29 And Ralph Cudworth implied throughout his famous

${ }^{28}$ Peter, Good Works for a Good Wagistrate (London, 1651), pp. 74-75, quoted by R. P. St earns, The strenuous Puritan: Hugh Peter (Urbana, Ill., 1954), pp. 5I-52.

29 Edward Cardwell; A History of Conferences (Oxford, 1840), p. 186, quoted by E. S. C. Gibson, The Thirty-Nine Articles (London, 1896), II, 482 . 
sermon before the House of Commons in 1647 that a great deal of fatalism, existed in the England of his day. "fe that builds," said Cudworth, "all his comfort upon an ungrounded perswasion, that God from all eternity hath loved him, and absolutely decreed him to life and, to happlness, and seeketh not for God really dwelling in his soul; he builds his house upon a Quicksand, and it shall suddenly be swallowed." 30

The conversion experience was central in Puritan thought concernigh salvation. Every Puritan had to undergo such an experfence, and it served as a means of distinguishing Puritans from other Anglicans. 31 Every man not a convert was susceptible of conversion, according to the teaching of English Purltan preachers. 32 The Puritans were much more concerned with this life than with eschatology, though. hell-fire preaching was not rare and the motivation for their concerm-with daily living, their scrupulousness, was basically otherworldly. 33 Puritans meditated on their conduct in this Iife, or, as Knappen puts it, "The Puritan

${ }^{30}$ Cudworth, A Sermon Preached Before the House of Commons (1647, facsimile text, New York, 1930), p.

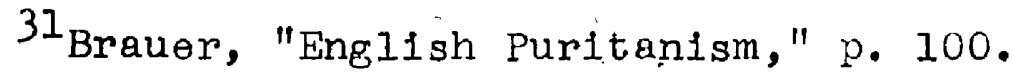

32 Haller, Puritanism, pp. 95 and 175. E. S. Morgan has observed that covenant theology in New England changed Puri tan theories so that many preachers came to regard only those within the covenant as susceptible. See The Puritan Family (Boston, 1944), pp. 97-1C4, and below.

33 Knappen, Tudor Puritanism, p. 351." 
Iived nine-tenths of his time for the joys of this world"-spiritual joys, that is. 34

In the conversion process, the sermon itself played the leading role; it was indeed regarded as almost the sole instrument of salvation. 35 Although Bible-reading was recognized as valuable, preaching was considered far moré important. According to Thomas Cartwright--and many other Puritans echoed his sentiments--"As the fire stirred giveth more heat, so the Word, as it.were blown by preaching, flameth more in the hearers, than when it is read. "16 Far from being didactic and subjective, the Puritan sermon declared to its hearers the revelation of God, and the word was confirmed in the hearts of the hearers, if they were of the elect. For matching the outward offer of salvation by the $\checkmark$.

34 I'wo Puritan Diaries, p. 9. See also Knappen, Tudor Puritanism, p. 35I. Miller agrees with Knappen on this point. See The New England Mind: The Seventeenth Century (Cambridge, IMass., 1954), pp. 37-38, hereafter cited as Seventeenth Century.

35"No Salvation can be expected where the Gospel is not preached."-Thomas Norton, The Orthodox Evangelist (London, 1654), p. 153. Calvin had said, ". . the voice of man is nothing but a sound that vanisheth in the ayre, and notwithstanding $1 \mathrm{t}$ is the power of God to saluation to all beleeuers - . "--Thirteen Sermons (London, 1579), folio 35. Calvin's sacramental view of preaching is implied in Ames's Warrow, pp. 143ff. And later, for samuel Willard, the gospel was "a medium used by God, for the bringing of Sinners to Falth in Christ, and so to Salvation."--A Compleat Body of Divinity (Boston, 1726), p. 436. iwost of this work was deilvered as sermons in the late seventeenth century.

36 iuoted by Horton Davies, The Worship of the English Puritans (Westminster, 1950), p. 186 . 
preacher was the inward offer, "a spiritual enlightening, whereby those promises are propounded to the hearts of all men, asiltwere by an inward word." 37 The vital function of the sermon for the Purttan is perhaps best indicated by Richard Baxter's saying, that in the sermon the preacher speaks to his congregation as "a dying man to dying men." 38

The Puritan sermon in the seventeenth century was usually divided into "doctrines" drawn from the text being used, and each doctrine had several "uses" or "applications." These varied uses were conveniently listed in the standard textbook of theology, William Ames's Medulla Sacrae Theologia'e (1630; English translation entitled The Marrow of Sacred Divinity):

Information is the proving of some truth... . Refutation is the confutation of some error.... Instruction is a demonstration of that life that is to be followed. - . Correction is a condemning of that $11 f e$ that is to be shunned. . . Consolation is the application of some argument, either to take away, or to mitigate griefe and oppressing feare. - Exhortation is the application of an argument, either to beget, cherish, and execute some inward vertue, or to further the exercise of 1t. . . .

37 Ames, Marrow, p. 111 .

38 Guoted by Davies, Worship, p. 184. An interesting insight into the preacher's attitude towards his own sermons as a means of grace is supplied by a passage from Thomas Shepard's autobiography: "I was desired to preach at - - [a] marriage; at which sermo the Lord first toucht the Mris. Margaret, with great terrours for sin \& her Christles estate."--"The Autobiography of Thomas Shepard," Pubs. Col. Soc. Mass., Pransactions, 1927-1930, XXVII (1932), p. 372 . 


\section{Admonition is the application of an argument to correct some vitiousnesse [sic.]." 39}

John Cotton's famous catechism Milkjor Babes teaches more about the function of preaching. First "the Ministry of the Law" should be preached; this will cause the elect hearer to know his sin and the wrath of God against him for $\therefore$ it and to feel his accursed estate and the need of a saviour. Then the "Ministry of the Gospel" serves to humble him even more and then finally raises him "up out of this estate. 40

The method of preaching by. which these ends were to be reached was expository preaching, Calvin's method. So ms taught the standard work on preaching, Wlliam Perkins's The Art of Prophecying (1592). But unlike Calvin's, Puritan sermons of the seventeenth century demonstrate that love for system which was a characteristic of the Puritan mind. Sermon after sermon follows the pattern of four steps set forth by Perkins:

1. To read the Text distinctly out of the Canonical Scriptures.

2. To give the sense and vnderstanding of 1 t being read, by the scripture it selfe. .

3. To collect a few and profitable points of doctrine out of the natvrall sense. 4. To apply (if he have the gift) the doctrines rightly collected, to the life and manners of men

39 Marrow, pp. 158-160.

40 Milk for Babes (London, 1646), pp. 7-8 (misnumbered $7-10)$. 
in a simple and plaine speech. 41

Two aspects of the last step are emphasized again and again in Puritan writings. First, the proof of the doctrines must be kept to the "commodity". of the hearers. 4.2 Second, the preacher must be specific in dealing with sins: general statements fail to have the effect of particular ones. 43

It was basic to Puritan theology (and to Reformed theology in general) that doctrines must be based on the Bible 44 --"proved by scriptural testimony"-for the Bible "is the word of God written in a language fit for the Church by men immediately called to be the Clerkes, or Secretaries of the holy Ghost." 45 We know this by God's own testimony. 46 "God," wrote Richard Sibbes, "joining with the soul and apirit of a man whom he intends to convert, beside that inbred light that is in the soul, causeth him to see a divine

4I Quoted by Mitchell, English Pulpit Oratiory, pp. 99100. Ames held that each doctrine must be explained in terms of use.--Marrow, pp. 156-157.

42 For example, Marrow, pp. 156-157.

43 For example, Ames, Marrow, p. 165.

44 Perry iniller and Thomas H. Johnson, eds., The Puritans (New York, 1938), pp. 41-54. 45 Ames, Marrow, p. 156.

46 Perkins, Workes (London, 1612-1613), II, 647. Ames says that God "did dictate and sugeest ali the words in which they [the Scriptures] should be written."-Marrow, p. 149 . 
majesty shining forth in the scriptures, so that there must be an infused establishing by the spirit to settle the heart in this first principle... that the scriptures are the word of God." 47 or, as William Perkins wrote, the one proof positive is "the inward testimony of the holy Ghost speaking in the scripture... 148

Besides preaching the gospel, the minlster of course administered the sacraments, whose role is discussed below in the treatment of covenant theology. In general it may be stated that, for the Puritan, the Sacraments did not bring salvation, but "sealed" the election of the saint, although such a sealing was not, strictly speaking, necessary. Along with preaching and prayer, the Sacraments are "outward and ordinary means, whereby Christ communicateth to us the benefits of Redemption"; but none of the three means are. "made effectual" except to the elect. 49 sibbes distinguished between the Reformed view and the High Church view of the sacraments: as a Reformed divine he held that "there is grace by them, though not in them." 50 The Lord's Supper was for

$$
47 \text { Works, ed. Grosart (Edinburgh, 1862-1864), III, } 427 \text {, }
$$
quoted by Geoffrey Nuttall, The Holy Spirit in puritan Faith and Experience (oxford, 1947), p. 23 .

48 Workes, II, 649. Calvin had said, "God alone' can properl $\overline{\mathrm{y} \text { bear }}$ witness to his own words..."--Institutes (London, 1953), Bk. I, Chap. 7, section iv.

49willard, Body of Divinity, p. 806.

50 Works; ed. Grosart, III, 134, quoted by Nuttall, Holy Spirit, - n. 91. 
the Puritan not so much a spiritual feeding intended to give the communicants the grace to overcome evil and be gaved, as a feast where Christ the Host delivers to the elect the benefits of his passion, benefits which had already been assigned to them. 51

Hooper, Smith, Perkins, Ames, and Preston

For an historical study such as this attempts tio be, an examination of the teachings of some important puritans is helpful and perhaps necessary. Of the early group of English Reformed writers, John Hooper is especially interesting. According to one of his biograohers, he "very effectively contributed to the popularizing of the extreme puritanic views of religion in England." 52 His views on conversion are stated more fully and distinctly than the views of most. English writers of the period. Beyond his personal influence, his teachings reached many, for his works continued to be republished during the latter part of the century. As has been observed, he was a follower of Bullinger.

In his Brief and Clear Confession of the Christian Faith (1550, republished 1581 and 1584), we find him writing: "I believe that the Father in Jesus Christ his son through

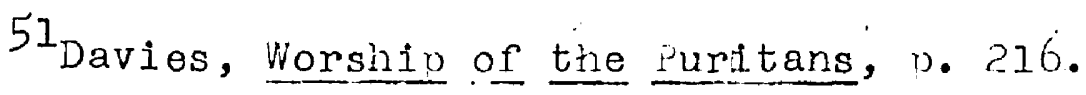

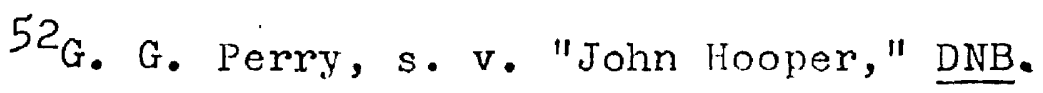


the Holy Ghost hath elected and chosen those that are his own, according to his good will, before the foundations of the world were laid, whom he hath predestinated unto life eternal . . "153 But although this staitement places Hooper in the Reformed tradition, another passage, from the epistle to his A declaration of the ten holy comaundementes (1548, republished 1550 and 1588 ), is in sharp contrast with Calvin's views on reprobation and man's inability. The promise of grace appertaineth unto every sort
of man in the world, and comprehendeth them all;
howbelt within certain limits, and bounds, the which
if men neglect or pass over, they exclude themselves
from the promises in Christ: As Cain was no more ex-
cluded, till he excluded himself, than Abel; Saul
than David; Judas than Peter; Esau than Jacob. . .
Howbelt . . [the] threatenings [of God] against
Esau, if he had not of his wilful malice excluded
himself from the promise of grace, should no more
have.hindered his salvgion, than God's threatenings
against Ninive. . . 54

Hooper's teachings are an excellent example of the kind of theology to be found among English writers of the Reformed tradition before scholasticism began to set in; later, this would have been labelled Arminianism. Another important Puritan, of a somewhat later period, is Henry Smith (c.1550-1591), the Chrysostom of the English pulpit,

53 Later Writings, ed. Charles Nevinson (Cambridge, Eng., 1852), p. 25. This quotation is from the eleventh of the hundred articles in the Confession.

\footnotetext{
54 Early Writings, ed. Samuel Carr (Cambridge, Eng.,
} 
- whose popularity is indicated by the fact that in the twenty-one years from 1589 to 1610, eighty-three editions of his sermons were published. 55

It is significant that in Smith's published writing 56 no references to Romans IX. 19-25 appear, a favorite text among the predestinarians. Further, one of his best sermons, "Jacob's Ladder, or The Way to Heaven," makes no mention at all of predestination. Smith's position on the salvation process can be pieced together from pronouncements appearing throughout his works. Rather than tell his hearers how to apply Christ's righteousness to themselves, more often Smith, like Calvin, assures his hearers that they are the eiflect and asks that they act accordingly:

The light of the Gentiles is our light, your light and my light: Christ is our grace, your grace and my grace; and Christ is our salvation, your salvation and my salvation. . . He came into the world when the world did abound in wickedness, and saved us when we most deserved wrath. Wonder at this, you that wonder at nothing, that the Lord would come to bring salvation, to redeem our lost souls, even, as - it were, against our wills; so that now we would not be as we were for a thousand worlds. 57

For Smith, "Christ is their salvation that bolieve in

55 See A. F. Herr, The Elizabethan Sermon (Philadelpiria, 1940), pp. 99-102; thitchell, Enclish Pulnit Oratory, pp.

56 irhe Works of Henry Smith, ed. Thomas Snith (Edin-

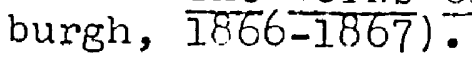

57 Works, II, 192 . 
him, and make much of him, and thankfully receive him."58 "If you will you may be saved, and the Lord will one day put those words into my mouth that will touch your hearts. Therefore now arise, kiss and embrace the sweet babe Jesus, wand then frame yourselves to obey him; for then the Lord will knock at your hearts, and if you will let him in, he will teach you all things."59 The passages are significant because, had they been uttered by a seventeenth-century Puritan (such as Hooker), the preacher would have made clear that only those whom God has elected will ever truly wilj. to be saved; that men can neither frame themselves to obey 'God nor thankfully receive Jesus: men can only usk God to give them the ability to do these things, things that natural man can never do. Although we may feel sure that Smith's abstract theological views were very similar to Calvin's, 60 he clearly did, not feel any necessity to discuss man's spiritual inabilities, let alone dwell on them at length. 61

On the important question of the perseverance of the saints Smith seems to have held pre-scholastic views. He wrote, ". . when thou art weary of thy godliness, God doth

$$
\begin{aligned}
& 58 \text { Works, II, } 180 . \\
& 59 \text { Works, II, } 186-187 \text {. } \\
& 60 \text { See his high praise of Calvin and Geineva in Works, }
\end{aligned}
$$
II; 311 .

${ }^{6} \mathrm{I}_{\text {For Smith's ideas on human spiritual ablity, see his }}$ Works, I, 67, and II, 193. 
not count thee good, but weary of godliness; and when thou declinest from righteousness, God doth not count thee righteous, but revolted from righteousness. . . As God's mercy endureth for ever, so our righteousness should endure for ever."62 For the "High Calvinist" or Bezaist, our right- eousness will endure for ever (with brlef.lapses), if we are of the elect. 63

of roughly the same period as Smith is William Perkins, probably the most famous and important Puritan theologian. At least eleven editions of his collected works were published during the period 1600-1635; his writings appeared in English, Latin, Spanish, Dutch, Welsh, and Irish. His influence was especially great in New England, and for seventeenth-century Puritans, he ranked with Calvin in importance. 64

\section{$62_{\text {Works }}$, II, 91.}

63 But Beza, like most of the other followers of calvin who believed in the perseverance doctrine, let himself slip at least once into heterodoxy on this doctrine. He contends in one place "that they which neuer had externall nor internall calling, they (if wee regard an ordinariacalling) must needes perish: but whosoeuer is once called, he hath set as it were his foote in the first entrie into the kingdome of heauen: and unlesse 1t be by h1s owne default, he shall come afterwards into the courts of God \& so by degrees into his Maiesties pallace."-- A Treatịe of M. Theodore Beza," pubIished in William Perkins, A golden Chaine (Cambridge, Eng., 1600), p. 182; italics mine. See also the passage Immediately following this one.

.64 See Wright," "William F'erlins," pp. 171, 192, 194; and willer, "The Marrow of Puritan Divinity," Pubs. Col. Soc. Mass., liransactions, 1933-1937, XXXII (1938), 255. 
Although Perkins was the author of abstract works, such as Armillia aurea, or A golden Chaine, again and again ho emphasized practical aspects of Christianity, giving advice on such everyday problems as business morality. In his - Exposition - - of Zephaniah he taught that godliness will bring prosperity to individuals and nations; in Christian oeconomie he dealt with home management problems. 65

Perkins is interesting because he combined with his, practical interests a very strict, "High Calvinist" supralapsarian theology, which is readily distinguishable from Calvin's Calvinism. $66^{6}$ Whereas Calvin's test of election is, as we have noted, simple, with the new, theology conversion becomes the chief end of man; to Calvin it was only the beginning. This new emphasis on assurance is shown by the title of one of Perkins's works', $\underline{\text { Case }}$ of Consclence, the greatest that euer vvas; Hovv a man may know whether he be the Childe of Ged, or no. The same emphasis is to be found In another of Perkins's works, the title of which is an

65 See Wright, "William Perkins," pp. 180-185. Although none of Hooker's extant sermons are practical in the way that Perkins's are, New England Puritan divines frequently preached on such practical subjects as the duties of husbands and wives. See E'. S. morgan, "Ligit on the Puritans from John Hall's Notebook," New England quarterly, XV (1942), 95-101, especially p. 99.

66 Perkins is also interesting, as we shall ser, because his teaching on the preparation process was not quite orthodox. For Perkins's position in relation to the Reformed theology, see Ritschl, Dogmengeschichte des Protestantismus, III (Guttingen, 1926), 300-303. . 
interesting revelation of the occasional disregard of predestinarianism by Puritans in practical matters: A Preatise tending unto a declaration whether a man be in the estate of damnation or in the estate of grace: and if he be in the first, how he may in time come out of it; if in the second, how he maie discerne 1t, and perseuelre to the end. 67 Another shift of emphasis, one we have already observed in the tightening up of Continental Reformed theology, is also to be observed in Perkins's writings. The subtitle of his treatise A golden Chaine is The Description of Theologie, containing the order of the causes of saluation and Damnation. 68 Apparent here is the new concern with the order of the divine decrees, the favorite topic of debate among Protestant scholastics of the Continental Reformed churches. Calvin wrote about the one decree of God; for him discussion of the decrees would have been purposeless hairsplitting.

A somewhat détailed discussion of Perkins's theology, especially as presented in A golden Chaine, is useful for our purposes, since it is a full flowering of "High Calvin$1 \mathrm{sm} "$ and will permit us to see how the new theology differs from Calvin's teaching. Two important differences strike

\footnotetext{
67For A Case, I use the edition of London, 1595; for A Preatise, the edition of London, 1589. ${ }^{68}$ I use the edition of Cambridge, 1600.
} 
the reader of A golden Chaine at once: (1) the material is arranged in a very intricate system, with divisions and subdivisions, and sub-subdivisions. 69 (2) Election and reprobation and "the application of Predestination" loom much larger here. Six chapters, more than ten per cent of the whole, are devoted to the subject of reprobation. Although double predestination is set forth early in the book (pages 10 and 11), few soteriological points are handled in the first hundred pages; then soteriology dominates the discussion. We are told that. "the gospel preached is - . [the] ordinary means to beget faith," and that, except in infants, the faith necessary for salvation is based on "a knowledge of Gods free promlse."70 Perkins then proceeds to present detafls of the steps in the "declaration of Gods loue." The four steps and their parts are as follows: I. Effectual calling, which has two aspects: election

${ }^{69}$ Compare Perry Miller's statement: "The great difference between Calvin and the so-called Calvinists of the seventeenth century is symbolized by the vast importance they attached to the one word, "method."--Seventeenth Century, p. 95. I would by no means agree that this symbolizes the great difference."

70 Pages 103 and $14 \%$. . inllier uses such statemerits as these as a basis for his idea that the New Englanders departed from orthodoxy by granting man ability to "prepare" himself for salvation, by listening to expositions of Christian doctrine, for examble. See Miller, "Preparation for Salvation' in Seventeenth-Century New England," Journal of the History of Ideas, IV (1943), 253-286. But I have no reason to believe that Calvin would have disagreed with the 'preparation" 1dea, although, as we shall see, some later 'High Calvinists" did. 
and union. In the latter God gives the elect to Christ as a freo gift. These two steps are accomplished by:

A. "The squing hearing of the word of God" (page 117), flrst the Law, then the gospel.

B. The bruising of the heart by:

1. The knowledge of the la w of God.

2. The knowledge of sin and its punishment.

3. Compunction for sin.

4. Recognition of one's inability to stop 'sinning.

C. Faith applied by the Holy Ghost, which causes man to:

1. Know the gospel.

2. Hope for pardon.

3. Be eager for the grace of Christ.

4. Approach the throne of grace with confession of sins and craving for pardon, based on the application of God's promises, which the Holy Ghost has persuaded man are his. This "perswasio is, \& ought to be in euery one." 71

71P. 119. The phrase "is \&: ought to be" represents the kind of confusion which one often finds in the Reformed the ology: predestination controls what "is," but the proacher holds man responsible for what "ought to be." 
II. Justification, in which those who belleve are accounted just through the obedience of Christ, who performed the Law for man. After justification man is to keep the Law only as a testimony of his falth. There are two parts to justification:

A. Remission of sins.

B. Imputation of the righteousness of Christ to the sinner.

III. Sanctification, in which men are delivered from sins and have their righteousness renewed by: A. Mortification: $\sin$ is kept under control. B. Vivification: holiness is created by the Holy Spirit.

IV. Repentance, which is based on sanctification, and In which man denies himself, professes Christ, and turns to God. 72

This somewhat lengthy and doubtless dull summary of an important section of Perkins!s most significant work has been presented in order to indicate the approach which the "High Calvinist" took. The order and divisions are significant because the same type of organization--indeed, almost the identical organization--was used again and again in the sermons of Thomas Hooker and other important iuritan preachers.

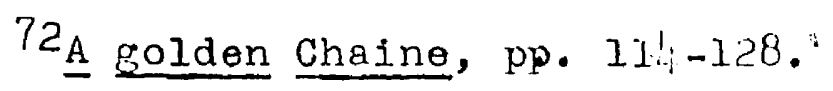


For the purposes of this study, the chapter entitled "Of the application of Predestination" (Chapter 58) is also helpful. Here we learn that the elect reach, in time, assurance of salvation by testimony of God's spirit and by the results of sanctification--thus by'both Calvin's and Beza's tests. Some of the effects of sanctification include, according to Perkins, the desire "to striue againgt the flesh," "to loue the ministers of Gods word," and "to flie all occasions of sinne." (page 77) But one must not conclude that he is a reprobate even if he has not observed in himself these effects. "Let him rather vse the word of God, and the Sacraments, that hee may haue an inward sense of the power of Christ, drawing him vnto him, and an assurance of his redemption by Christs death and passion." 73

Perkins's detalled listing of the qualities of the elect here and elsewhere ${ }^{74}$ seems clearly designed to persuade the reader to adopt these qualities; however, Perkins doubtless would have defended the list as an aid in

73 P. 78. Where the conversion experience and the concept of effectual calling fit into this discussion of assurance is unclear. Perking's attitude towards the Sacraments does not seem altogether orthodox, if the person who is ex-" horted to use the Sacraments is as yet uncalled. Should this be what is meant, then Perkins's view is similair to that of the seventeenth- and eighteenth-century Puritan "heretic" Solomon stoddard. For "stoddardeanisil" see Perry vililer, the New England wind: From Colony to trovince (Cambridge, inass., 1953), especialiy pi. 227-236, hereafter cited as Colony to Province.

$$
74 \text { For example, A Treatise, pr. } 28 \mathrm{f}^{\circ} \text {. }
$$


performing the duty which he believed every man to have: to examine his soul to see "whether hee be in the faith or not. 175

Clearly Perkins had a far greater concern with the health of his followers' souls (and with their apprehension of 1 t) than we found Calvin to have had. Perkins was especially concerned with the question of how far a reprobate can go down the path to salvation, and how far a saint must go before he can be considered saved. All that a saint must have is a faith "compared to the graine of mustard seed, the least of all seedes"; 76 for if a man ". : doth but begin to be conuerted, [he] is euen at that instant, the very child of God, though inwardly he may be more carnall than spirituall."77 "To see and feele in our selues the want of any grace pertaining to saluation, and to be grieued therefore, is the grace itselfe." 78 on the other hand, a reprobate may have most signs of election, 79 for many reprobates are called (though not "effectually") and are to a degree onlightened, have penftence, a temporary faith, even a "tasting" of justification and sanctification, and

75 "To the Reader," in A Treatise.

76 Workes, I, 366.

$77_{\text {Workes, }}$ I, 637 :

78 Workes, I, 6/.1. Seé also A golden Chaine, pp. 120${ }^{79}$ A Preatise, $1 p .1-27$. 
demonstrate for a time, before finally falling away, an out-.. ward holiness of life. 80 Determining one's spiritual health is clearly no easy matter. For Calvin, assurance was to be achieved in order that a Christian might go on with his duties; for Perkins, one's duty was achleving assurance, or rather, it would seem, achieving salvation.

One final passage from Perkins is worth quoting, for it demonstrates how far even a "High Calvinist" departed from his theology in practical application. "God hath appointed," writes Perkins, "vnto every man that liues in the Church a certaine time of repentance, \& of comging to Christ. And hee which misspendeth that time, \& is not made a Christian then, can neuer be saved." 81 What this, Implies it is hard to say. Does every man have an equal opportunity to be saved, an opportunity which he may spend or misspend? $\mathrm{Or}$ is It that the elect manifest themselves by responding to the call, the reprobate by falling to respond? The passage has the kind of ambiguity which can be found in much Reformed writing on practical, applied subjects: it can be read so that it is consistent with predestinarianism, but at the same time it offers hope to al1. 82

William Ames (1576-1633), author of another standard

80 A golden Chaine, pp. 176-179.

$81_{\text {Workes }}, I, 379$.

- 82 For the effects of the Purttan doctrines here presented by Perkins, see Bunyan's Grace Abounding to the Chief of Sinners. 
textbook of Puritanism, especially the New England variety, is a significant representative of a period of theological. development. somewhat later than Perkins. 83 As we shall see later, he is an important figure in the new school of covenant theology. But except for the sections on the covenants, Ames's Marrow of Sacred Divinity contains nothing particularly divergent from the earlier Reformed theology of such divines as Perkins. But there is an important new emphasis on the process by which man receives the benefits of Christ's redemption, and a more detailed account of the steps which man may take in order to be saved. On these developments our discussion of Ames will focus.

Ames is clearly a believer in the limited atonement: ". . application is altogether of the same latitude with redemption it selfe, that is, the redemption of Christ is allied to all and only those, for whom it was obtained, by the intention of Christ and the Father... ."84. Although this process of application is treated in the Wiarrow in detall--with chapters on calling, fustification, adoption, sanctification, and glorification--the chapter on vocation or calling is most relevant here.

${ }^{83}$ For Ames's influence, see 1 iller, Severiteenth Century, p. 48. Miller calls Ames's Conscience with the power and Cases thereof the puritan "gulde book for earthy existence."--Colony to province, p. 40.

84 Niarrow, P. 1.00 . 
The parts of the process of vocation, for Ames, are two: the "offer of Christ, and the receiving him... The offer is an objective propounding of Christ, as of a meanes sufficlent and necessary to salvation." 85 . The instruments of the offer are preaching, the "outward offer," and the Holy Ghost, who by an inward of fer spiritually enlightens the hearts of the men who are to be saved. 86 If it is their time, men then passively receive Christ by means of "a spiritual principle of grace. . begotten in the will of man"; in the will because its conversion "is an effectual principle of the conversion of the whole man." The will is not free.but is under "obedientiall subjection." Faith is the result of this new grace, and it is exercised "certainly unavoydably and unchangeably."87 Faith comes first in the process of conversion, but repentance, though caused by faith, is perceived first. ${ }^{88}$ The real order and the perceived order are not the same. 89

After digesting such statements as these, the non-predestinarian may be at least momentarily bewildered by Ames is discussion elsewhere of man's role in the salvation process.

85 Marrow, p. 110. 86 Marrow, p. 311 .

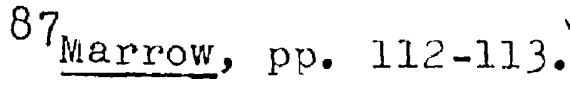

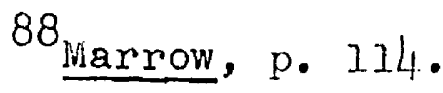

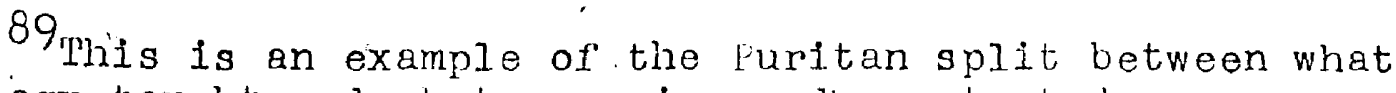
theology taught and what experience demonstrated. 
In answer to the question "What ought a man to do, that he may be translated out of a state of sin, into the state of Grace?" Ames responds, examine yourself by the Law, convict yourself of sin, despair of being saved by self-rellance or help from man, achieve true humlilation. 90 Ames also answers the questions of "what a man is to doe that he may repent," 91 "what a man ought to doe that hee may obtaine the lively act, and the sense of it [adoption],"92 and "what a man ought to do that he may be sanctified." 93 We may also learn from Ames how to make progress in sanctification. 94 Even the means to the supposedly key step, obtaining faith, is set forth by Ames. 95

How is it that Ames (and Perkins) can present strict predestinarian views and yet give details about how to take the steps in the salvation process, from vocation to sanctrfication, when the process for the elect is completely controlled by God? The answer is not far to seek. Since election "makes no inward difference in the predestinate themselves before the actuall dispensation of this application, 196

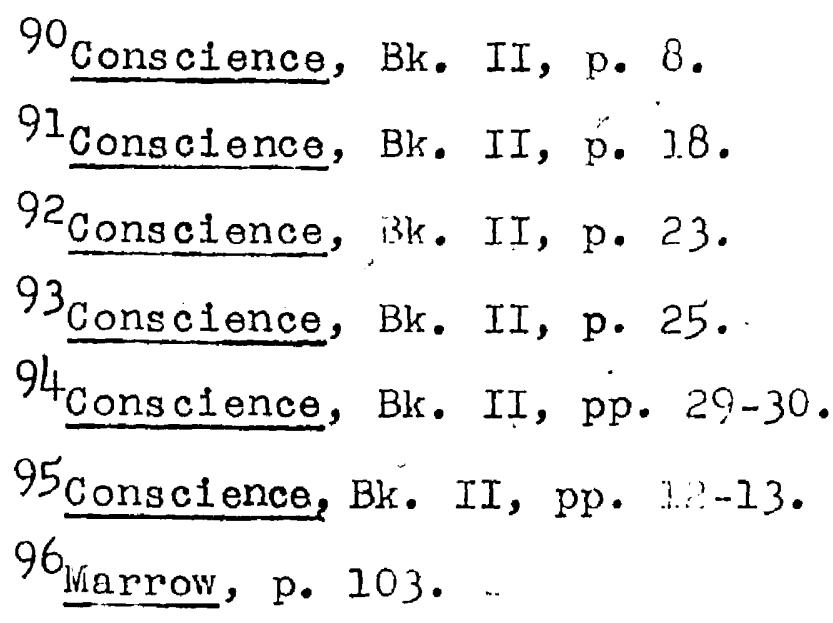


one who seriously wishes to find the way to salvation is interested simply because he is predestined to be saved. When he has discovered what the means prescribed are, he will take advantage of what he has learned; he w1ll follow the prescribed course. This is God's method of bringing men to salvation, according to Samuel Willard, because to be "carried by instinct, and a blind impulse" "would be to treat us, not as men, but as brutes." God's way is "by Counsel," for indeed "believing in Christ, is a most dellberate act. The man considers and sees reason for what he doth." 97

It is true that Willard's explanation is somewhat boider than Perkins's or Ames's would have been: the word "reason" looms larger in Willard's discussion than it would have in an earlier period, and over fifty years separates Willard and Ames. But an explanation is needed, and Willard's is doubtless correct. Perry vilizer uses a Willard-like interpretation to explain how the Puritans reconclled predestination and exhortations to save one's self. He suggests that "sermons are the chief means of salvation because they are best accomnodated to God's treating with men as with rational creatures, and ministers who carry the Gospel to the world must persuade the mind of the world to believe." 98

\footnotetext{
97 Body of Divinity, D. 451. According to miller, Willard's great work "always sumarizes New ungland opinion." - - Seventeenth Century, D. 199.

98 Seventeentic Century, p. 292.
} 
Further understanding of how the Puritans reconciled the seeming opposites is supplied by one of the best preachers of seventeenth-century Puritanisin, John Preston (15871628), who was very influential in both old and New England. 99

Although a full discussion of Preston's writings is more relevgnt to the discussion below of "preparation for salvation," some mention here of his teaching is necessary. One of Preston's most interesting works is posthumous: The Position of John Preston .. - Concerning the Irresistibil1ty of Grace, in which he is revealed to be a super-subtle Protestant scholastic of the "High Calvinist" school. The work is especially interesting because the position which. Preston sets forth he describes as "our opinion": the opinion, that is, of the Puritan party. The work, though extremely abstruse, should be studied by all students of Puritanism. Here only one portion, albelt an important one, can be examined. Preston's position is that grace is irresistible and yet man remains free: irresistible in fact, grace from the point of view of the person undergoing the process appears to be resistible. Preston considers the conversion process in four steps:

1. God infuseth into the whole soule, and so into the Will, a habit or quality of holinesse, renewing it, and making it, of evill good, of unwilling

${ }^{99}$ Seventeentli Century, pp. 18, 186, 200 and passim. 
willing: 100 by which meanes, that which belongs to the nature of the Will, is preserved entire, but that which was corrupt is rectified. 2. From the quality so infused, presently there arise in the Will, certaine imperfect inclinations, preventing the notice of reason, like unto those which the School-men call the very first Motions of the heart. For by these the will doth not compleatly, and effectually will that which is good, but is onely initially, and incompleatly inclined to those good workes which please God, from whence such acts may be called, not so much willings, as wishings and wouldings.

3. Those inclinations are presented as an object to the understanding, which weighs them, debates them, takes counsel about them; and at length, when it hath by its ultimate, and conclusive dictates, confirmed them, propounds them to the will as to be chosen.

4. After those initiall inclinations, arising from Infused Grace, have passed the censure of the understanding and are allowed by the preceding judgement there of; then at length doth the Will put forth a compleat and effectual willingnesse, from which conversion immediately doth follow, or rather that very willing is the conversion of a man unto God.101

From this passage much can be learned. Perhaps most significant is the light It shods on the Puritan preacher's attempts to persuade the understanding of his hearers. Persuading itself was not enough; even the most persuasive preacher could do nothing with the understanding of even the most (seemingly) rational men unless God effected the inward means of salvation to match the outward means, preaching; and whom God had chosen to be called was, of coúrse, unknown. All man could do was to assume that any man migint be an

\footnotetext{
ine's.

100 An echo of a frequently-quoted phrase of St. Augus-

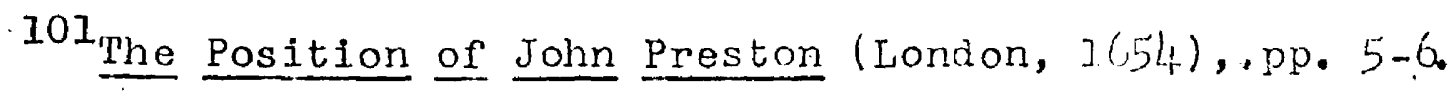


uncalled saint, and then apply all the persuasion that could be mustered. But the barrier to salvation was in the depraved will of man, and not in the understanding. Although Puritan psychologies usually gave the understanding dominion over the will in man as God created him, the will, since the Fall, is."driver of âll faculties," according to Preston. 102 Thus for Preston and Ames, like Calvin, the sermon was sacramental in nature.

- The order which Preston sets forth also deserves attention. It seems that inward grace works before the reason observes its action ("preventing the notice of reason"). Then, presumably, man recognizes the validity of the preached gospel only after grace has permitted him to recognize it. In a sense the gospel preached might be regarded as being, for the elect, the "rationalizing" of grace. In Redeemed Man, ag contrasted with Natural Man, the will follows the judgment of reason, and this new and proper order is itself conversion. 'Grace is irresistible; yét man remains free.

In passages in another work, The Brest-Plate of Faith and Love, Preston reveals more clearly than Ames, Perkins, or most other Puritan preachers the relationship of man's

102 : zuoted by Wilier, Seventeentil Century, p. 249. Milier's discussion of the Puritan ideas of the relationship of the will to the understanding is much less clear than most of his presentation, but his quotations are helpful. His full discussion occupies pages 248-251. 
ability to predestination. According to Preston, "That righteousness, by which alone we can be saved now in the time of the Gospel, is revealèd and offered to all that will take it."103 The same point is made again and again: ". . It is given to every man, there is "not a man excepted" (page 7). But all of this is not to say that Preston believes only in the "general" or outward calling, rather than in the "particular" or inward calling. "Indeed, when Christ was offered to every man, and one recelved him, another rejected him, then the Mystery of Election \&. Reprobation was revealed,. the reason why some received him being, because God gave them a heart, which to the rest he gave not" (page 8). But since the aim of the predestinarian Preston is persuasion, he contends that no sin "shall be so much layd to your charge at the day of Judgement, as your rejecting of the Sonne, and of his righteousnesse revealed, and freely of fered to you"; though indeed the means of receiving the son is "the gift of faith . . a fruit of election."104 More than most Puritans Preston emphasizes the connection between ethics and faith, the relationship so central to Calvin's thought. "I say," says Preston, "he that hath the strongest Faith, he that beleeves in the greatest degree the promises of pardon and remission, I dare boldly say, he

\footnotetext{
103 Brest-plate (London, 1651; first edition, 1630), p. 2 . 104 Brest-Plate; pp. 22 and 10.
} 
hath the holiest heart, and the hollest Iffe. For that is. the roote of $1 t$, it ariseth from that roote... "105

It is worth noting that Preston, like other leading conversion preachers--among them Hooker and Shepard--seems to assume that his hearers know wherein holiness $11 \theta$. In their writings we do not often find the kind of practical advice conceming everyday Christian duties that can be observed in such earlier writings as those of Perkins and Smith.

Some Anglican Views

Before we examine symbols of faith in order to observe how Reformed thought developed in England, it may be instructive to look briefly at the conversion teaching of some non-Puritan Anglicans. 106 one of the most useful documents is the offlcial collection of sermons read again and again from the pulpit throughout Elizabeth's relgn, the two books of Certaine Sermons or Homilies Appointed to be Read in Churches. According to Philip Hughes, the first five. homilies of the first book "form the earliest manifesto to

\section{The Nevv Covenant (London, 1634; first edition,} 1629), p. $349-350$.

106 The term "Anglican" could of course be used to describe Perkins, Smith, Hooper and even Preston, but is less defensible for Ames, a professor at Franeker, and for Hooker and the other New Englanders. 
proclaim the fundamentals of the Protestant Reformation as the official religion of the Ecclesia Anglicana."107 The very titles of these homilies reveal thelr emphasis: (1) A Fruitful Exhortation to the reading of Holy Scripture; (2) of the misery of all Mankind; (3) Of the Salvation of all Mank1nd; (4) Of the true and Ilvely Faith; and (5) of Good Works. Although the homilies teach doctrine which is clearly Protestant and emphasizes justification sola fide and the Pauline concept of the relation of faith to good works, they are definitely not. in the Reformed tradition, but more nearly Lutheran. 108

The concept of total depravity is very prominent. One eloquent passage puts it as follows:

We are all become unclean, but we all are not able to cleanse our selves, nor make one another of us clean. We are by nature the children of God's wrath, but we are not able to make our selves the children and inheritors of God's glory. . . . we " can-find in our sélves no hope of salvation, but rather whatsoever maketh unto our destruction.109

After this passage comes, not praise of God for electing. some from this state of utter depravity, but praise of God for providing men with the means of grace and the hope of glory. It, may have been the lack of predestinarian teaching

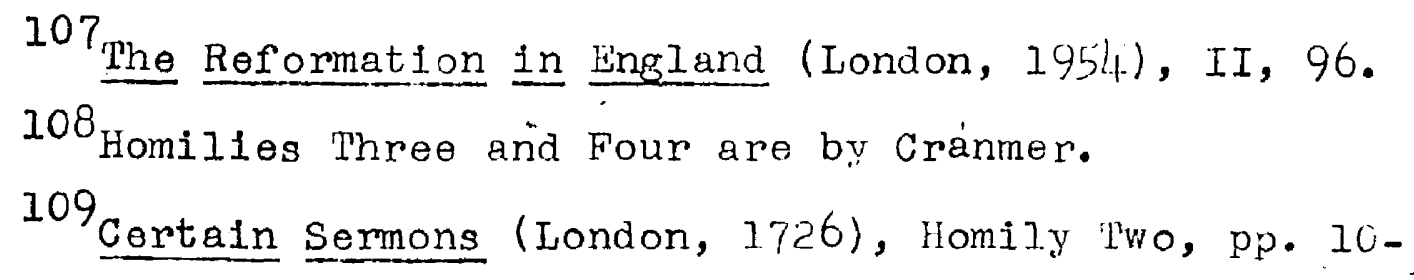


which caused the Purltans to contend in 1616 that the Hom1Iies do not contain godly doctrine in every point. 110

In the sermons of Archb1shop Edwin Sandys (c.1518-1588) the same concept appears as in the Homilies: "He [God] commandeth vs - to doe that which of our selues we are not able to doe; that seeing our want, we may craue hls grace and helpe, which will enable vs to drawe neere vnto him."ll Perhaps we should not take too serfously the lack of predestinarian views in Sandys's sermons. His sermon "Draw neere to God, and he will drawe neere to youlli2 is doctrinally very similar to "Jacob's Ladder," a sermon on the same topic --the way to Heaven--by the Puritan "Calvinist" Henry Smith. A reading of seventeenth-century "High Calvinist" sermons probably would lead one to expect greater emphasis on predestination and man's inability in Elizabethan sermons than one actually finds there. But if the Homilies and other sermons of sixteentil-century Anglicans lack the strict doctrines of the later period; the lack is less obvious in the doctrinal treatises of the period. We have observed that only two purely theological treatises were written by English Protestants in Elizabeth's reign. Fil other works,

${ }^{110}$ See Davies; Worship of the Puritans, $\mathrm{p} .187$. It is interesting to note that Bucer found the teachings of the Homliles in agreement with his own teaching and that of his fellow reformers ..."--Constantin Hopf, lnartin Bucer and the English Reformation (0xford, 1446), p. 81.

$111_{\text {Sermons }}$ (London, 1616), p. 57.

112 Sermon seven in the collected edition cited. 
such as catechisms, did appear. One of the most important of these works is the semi-official catechism by Aiexander Nowell (c.1507-1602), Dean of St. Paul's.113 Though not labelled a Puritan, Nowell was a strict predestinarian, as the following passage makes clear:

sto

They that be stedfast, stable, and constant in the faith, were chosen and appointed, and (as we term it) predestinated to this so great felicity, before the foundations of the world were laid; whereof they have a witness within them in their souls, the spirit of Christ the author, and thereunto also the most sure pledge of this confidence.114

In the seventeenth century 'the Church' of England was no more free from Protestant scholasticism of the Reformed variety than Puritanism was. Anglican scholasticism is manifested in Joseph Hall's very. Interesting work, "Via Media: The Way of Peace" (c.1623). Hall, later a bishop, here tries to settle on a compromise between the "High Calvinists" and the Arminians on the "Five Points," and in the process reveals that although not quite willing to go along with all five polnts of the Synod of Dort, he nevertheless stands with the strict supralapsarians on important points. One passage in the "Via Media" is interesting also for its similarity to the passage from John Preston quoted at length

113 A Catechism, ed. G. E. Corrie (Cambridge, Eng., 1853). For a discussion of its status, see pp. iv-vi. It was published in 1570, 1571, 1574, and 1576 .

$114_{\text {A Catechisin, p. } 171 .}$ 
above:

God, when he will and to whom he will, gives such an abundant, such powerful, such congruous, otherwise effectual grac $\theta$, that, although the will may, in respect of the liberty thereof, resist; yet it resists not, but doth certainly and infallibly obey: and that thus God deals with those, whom he hath chosen in Chrifte so far as shall be necessary to their salvation.115 :

Hal1, like Preston, contends that though grace is 1rresistible, man!'s will remains free.

Another passage reveals that Hall not only believed in the doctrine of irresistible grace but even regarded it as a standard doctrine:

To hold, that faith is so the gift of God, as that he doth not only give common and sufficient helps to men whereby they are made able to believe, if they will, but so works in them by his grace that they do by the power thereof actually believe and conceive true figth in their soul--this is fair and orthodox. 116

It would be difficult to find a more extreme statement of the doctrine of irresistible grace than Hall's. His position on the doctrine of the perseverance of the saints is similarly extreme. 117

115 Works (oxford, 1837), $x, 494$. Hall's terns for describing grace were carefuliy chosen from Roman Catholic, Arminian, and "High Calvinist" sources.

$$
116 \text { Works, } x, 483 .
$$

117 Works, $x, 496$. The position of Richard Hooker (c.1554-1600), the most important Anglican theologian, is presented below in comnection with the discussion of the Lamboth Articles. 
English Reformed Symbols of Falth

In the doctrinal history of Puritanism, three documents are significant: the two official religious formularies, the Anglican Thirty-Nine Articles (1563) and the Westminster Confession (1648); and the unofficial but useful Lambeth Articles (1595).118

That the Anglican Articles of Religion contain a statement of predestinarian views stricter than most Continental Reformed symbols--stricter than any of the sixteenth century which we have examined--is an observation which has seldom been made. Article XVII, "Of Predestination and election," which is the longest of the articles, states clearly the doctrine of double predestination. While the article is too lengthy to be quoted here in its entirety, the following portions are especially relevant:

Predestination to lyfe is the euerlastyng purpose of God, whereby (before the foundations of the world - were layd) he hath constantly decreed by his councell secrete to us, to deliuer from curse and damnation, those whom he hath chosen in Christe out of mankynd, and to bryng them by Christ to euerlastyng saluation, as vessels made to honour. Wherefore they which be endued with so excellent a benefite of God, be called accordyng to Gods purpose by his spirit workyng in due season: they through grace obey the callyng: they be iustified freely: they be made sonnes of God by adoption: they be made lyke the Image of. his onelye begotten sonne Jesus

\footnotetext{
$\frac{1}{118}$ The revision of the Thirty-Nine Articles begun by nestminster Assembly went only as far as Article XV. otice of a revision is given below.
} 
Christe: they walke religlously in good workes, and at length by Gods mercy, they attaine to euerlastyng felicitie.

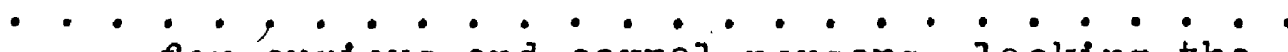
- - for curious and carnal persons, lacking the spirite of Christe, to haue continualiy before their eyes the sentence of Gods predestination, is a most daungerous downefall, whereby the deuyll doth thrust them elther into desperation, or into rechelesnesse of most vnclean living, no lesse perilous than desperation. 119

It is not surprising that in 1643 the Puritans regarded the Articles as orthodox and sound; $;^{120}$ as schaff puts it, the article on predestination contains "all that is essential, and a matter of dogma in the Reformed Churches."12I Reprobation is clearly implied--no one was ever "thrust into desperation" by Arminian doctrine. Grace is irresistible: "they through grace obey the calling"; there is no question of resisting it. The saints persevere: "they attain to euerlastyng fellcitie."

On two other of the so-called "Five Points" the Articles are less clearly "High Calvinist." Article II states that Christ was a sacrifice for "all actual sing of men" as well as original sin. The Puritans, when revising the Articles, left out the "all" in order to make the article

$119_{\text {Schaff, Creeds, }}$ III", 497-498.

120 Schaff, Creeds, I, 754 .

${ }^{121}$ Schaff, Creeds, I, 635. See also pp. 623 and 634. 
conform to the doctrine of a limited atonement.122 Article IX, "of Original or Birth-Sin,". refers to man as "very far gone from original righteousness"; the Puritans revised this later to read, "wholly deprived of original righteousness."123 The second is of course more explicit, although the first may seem extreme enough.

Although the Lambeth Articles were never proclalmed as official doctine within the Church of England, Thomas Fuller says that they contain "the general and received doctrine of England in that age ..."124 That they were at least close to being this may be suggested by presenting in juxtaposition the nine articles and eight statements in which Richard Hooker, the foremost Anglican theologlan, summed up his own position on the/same doctrines. The Larn- 1 beth Articles appeared in 1595; Hooker stated his position in the later 1590 's.

İambeth Articles

1. God from eternity hath predestinated certain men unto Iffe; certain men he hath reprobated.

\section{Richard Hooker's Position}

1. That God hath predestinated certain men, not all merı.

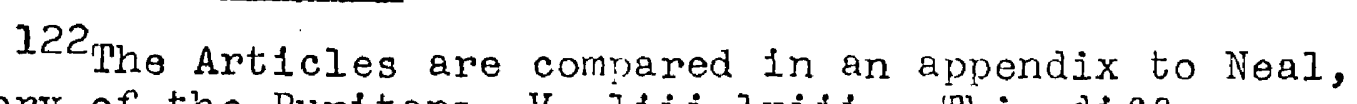
History of the Puritans, V, I1ii-lxili. This difference is

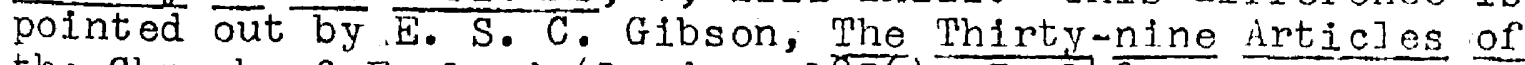
the Church of England (London, 18376), I, $14 \%$.

- ${ }^{123} \mathrm{Neal}$, History of the Puritians, V, Iviii.

124 Church History of Britain (0xford, 184.5), V, 227, quoted by Schaff, Creeds, I, 658. -ior the bacheround of the Articles, see Dawley, Whitgift, pp. 208-22l. 
2. The moving or efficlent cause of predestination unto Iife is not the foresight of faith, or of perseverance, or of good works, or of any thing that is in the persons predestinated, but only the good w11l and pleasure of God.

3. There is predetermined a certain number of the predestinate, which can neither be augmented nor diminished.

4. Those who are not predestinated shall be necessarily damned for their sins.

5. A true, IIving, and justifying faith; and the spirit of God justifying [Latin original :sanctificans] is not extinguished, falieth not away; 1t vanisheth not away in the elect, either finally or totally.

6. A man truly falthful, that is, such a one who is endued with a justifying faith, is certain, with the full assurance of faith, of the remission of his sins and of his everlasting salvation by Christ.

7. Saving grace is not given, is not granted, is not communicated to all men by which they may be saved if they wi1l.

8. No man can come unto Christ unless it shall be given unto him, and unless the Father. shall draw him; and all men. are not drawn by the Father, that they may come to the Son.
2. That the cause, moving him hereunto, was not the foresight of any virtue in us at all.

3. That to him the number of his elect is definitely known.

4. That 1t cannot be but their sins must condemn them, to whom the purpose of his saving mercy doth not extend.

15. That to God's foreknown elect final continuance of grace is given.

[No equivalent.]
6. That inward grace, whereby to be saved, is deservedly not given unto all men.

7. That no man cometh unto Christ, whom God, by the inward grace of his spirit, draweth not. 
9. It is not in the will or power 1 ff $^{\text {every one to be }}$
8. And that it is not in every, no not in any man's mere ability, freedom, and power, to be saved, no man's salvation being possible without grace. Howbeit, God is no favorer of sloth; and therefore there can be no such absolute decree, touching man's salvation as on our part includeth no necessity of care and travail, but shall certainly take effect, whether we ounselves do wake or sleep. 126

That the Lambeth Articles teach "High Calvinism" is readily evident. Although Hooker's comrnents on the last article make clear that he did not like the emphasis of the Articles, it is to be observed that only on the question of assurance of election does he seem to have been unwililing to go along with the conclusions presented. Admittedly, his position is less extreme, especially on questions of reprobation, but the Articles themselves are even more extreme than the Canons of Dort. Richard Hooker's position is only, in Schaff's phrase, a "slight modjfication" of the Articles. 127 Hooker is more nearly an Arminian than the great majority of sixteenth-century Anglicans; according to a prominent nineteenth-century Anglican, ". . during an

125 Schaff, Creeds, III, 523-524.

126 works, ed. Keble, Church, and Paget (Oxford, 1888), II, $596-597$.

127 Schaff, Creecis, I, G6i. See F. F. Pam?, Jr., "Studies in the Origins of endilish Arminianism," unpub. diss. (Harvard, 1950). 
interval of nearly thirty years the most extreme opinions of the school of Calvin, not excluding his theory of irrespective reprobation, were predominant in almost every town and parish."128 We may conclude that Fuller's statement, as well as Archbishop Whitgift's own description of the Articles, 129 is accurate enough: they represented the consensus of the Church of England.

The most important symbol of faith for our purposes is not an Anglican document, but one which represents solely the Puritan point of view: the very full and detailed Westminster Confession. 130 According to Schaff, the Confession shows the "Calvinist system in its scholastic maturity."I3I Although the work was not prepared until the $1640^{\prime} \mathrm{s}$, like all symbols of faith it sets forth only what had come to be accepted as orthodox by a large number of divines of its party. The Confession contains the very theology that Puritans had been preaching; Ames, Preston, and Hooker were amone its exponents. Miller has contended that ". . the Confession was written by Presbyterian Calvinists, not

128 Archdeacon Hardwick, History of the Articles (2nd ed.), quoted by Dowden, Outitines, p. 67 . The period was the close of Elizabeth's reign.

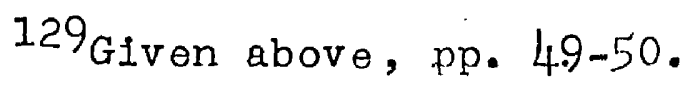
${ }^{130}$ In Schaff's parallel-column Latin-tinglish text, the. Confession occuples seventy-three pages.

131 Creeds, I, 760. Schaff observes that the authors were weli acquainted with recent developments in Continental Reformed theology. 
quite sophisticated enough to grasp the subtleties of the Covenant". Idea. 132 But Chapter VII is devoted to the topic "Of God's covenant with man"; and, as Schaff notes, this is the first inclusion of the covenant idea in a symbol of faith. 133

Although in soteriology the Confession is similar to the Lambeth Articles, there are some new elements and now emphases. After a clear exposition of double predestination, 134 a discussion of effectual calline is presented, significant for the role which "means" of conversion plays in the process:

As God hath appointed the elect unto glory, so hath

P he, by the eternal and most free purpose of his will, foreordained all the means thereunto. Wherefore they who are elected, being fallen in Adam, are redeemed in Christ, are effectually called unto faith in Christ by his Spirit working in due season; are justified, adopted, sanctified, and kept by his power through faith unto salvation. Neither are any

${ }^{132}$ Colony to Province, p. 55.

133 Schaff, Creeds, I, 773. It is significant that in the standard study of covenant theology, there is a discussion of the Westminster Confession. See Gottlob Schrenk, Gottesrelch und Bund Im HIteren Protestantismus vornehmlich be1 Johannes Coccejus TGutersioh, 1923). Of the Confession, Schrenk writes, "Hier macht zum erten Male ein Bekentris die Flderallehre fur eine grosse Kirche symbolisch." (p. 82) Although Hooker, John Cotton, and John Davenport were invited to attend the assembly, they did not make the trip. But the Massachusetts synod of $16 / 1.8$ endorsed the. Confession as orthodox. See G. I. Walker, Thomas Hooker (New York, 1891), pp. 136-138, and Fliler, Colony to Province, pp. 3-4. 134 Chapter III, section 3 . 
other redeemed by Christ, effectually called, justified, adopted, sanctified, and saved, but the elect only. 135

Also significant is that the authors of the Confession agree with Calvin on a basic question: the use of the doctrine of predestination should be to assure men who attend the will of God and yield obedience to it that they have been elected. If so used, the dóctrine will ". . afford matter of praise, reverence, and admiration of God."136

In the light of the Puritan concern with preparation for salvation, 137 it is worth noting that according to the orthodoxy of the Confession, man is not only unable to convert himself, but is also unable "to prepare himself thereto."I38 only in effectual calling does God, by drawing mer from their state of sin, enlighten thelr minds so that they may understand God's will. But even more important than this enlightening is the renewing of men's wills, "and by his almighty power determining them to that which is good, and effectually drawing them to Jesus "Christ; yet so as they come most freely, being made willing by his grace."139

135 Chapter II, section 6, Schaff, Creeds, III, 609-610. ${ }^{136}$ Chapter, III, section 7, Schaff, Creeds, III, 610. 137 See Milier, "Preparation for Salvation, " and
below.

${ }^{138}$ IX, 3, Schaff, Creeds, III, 623.

$139 \mathrm{X}, 1$, Schaff, Creeds, III, 624. 
Saving grace is irresistible, and yet man remains free, for he is released from bondage to $\sin$ when he is renewed by the Holy spirit and is "thereby enabled to answer this call, and to embrace the grace offered and conveyed in it." 140 The position of John Preston has now been codified.

The teaching of the Confession on the role of preaching is also what we might expect after having read what Perking and Ames have to say on the subject, although the presentation in the Confession is much less detailed. The central passage reads, ". - the grace of faith, whereby the elect are enabled to believe to the saving of their souls, is the work of the spirit of Christ in their hearts, and is ord1narily wrought by the ministry of the word...".141 "By this falth a Christian believeth to be true whatsoever is revealed in the Word, for the authority of God himself speaking therein... "I42 Although the passage does not make clear that preaching was sacramental to the authors of the Confession, perhaps we can reach such a conclusion on the basis of a phrase in the chapter "Of effectual Calling": those whom God has elected "he is pleased". . effectually

$140 \mathrm{x}, 2$, Schaff, creeds, III, 625.

${ }^{141}$ XIV, I, Schaff, Creeds, III, 630. The quotation continues: "by which also, and by the administration of the sacraments and prayer, it is increased and strengthened." $142 x I V, 2$, Schaff, Creids, III, 630. 
to call, by his Word and Spirit..." outwardly, by preaching; the Splrit, inwardly.

Calvin's doctrine of assurance of salvation has an important place in the Confession: it occupies an entire chapter. But the new emphasis on the necessity of careful examination for proof is quite unlike Calvin's teaching. "This infallible assurance doth not so belong to the essence of faith, but that a true believer may wait long, and conflict with many difficulties before he be partaker of it." 144. When we remember Calvin's belief that man would obey God only if he wère assured of God's favor towards him, we can readily see the change.

The Confession is more expliclt than any earlier confession on two of the "Five Points": perseverance and the limited atonement. The first section of the chapter on perseverance reads, "They whom God hath accepted in his Beloved, effectually called and sanctified by his spirit, can neither totally nor finally fall away from the state of grace; but shall certainly persevere therein to the end, and be eternally saved." 145 In the chapter "Of Christ the Mediator" the Confession states as doctrine, "To all those for whom Christ hath purchased redemption he doth certainly and

$143 \mathrm{x}, 1$, Schaff, creeds, III, 624; italics mine. 144 XVIII, 3, Schaff, creeds, III, 638. 145XVII, '1, Schafr, Creeds, III, 636. 
effectually apply and communicate the same...."146 Christ died for the elect only.

We have observed the development of the Reformed theology from the time of Calvin to the Westminster Confession, a period of over one hundred years. Within the party that retained the name of orthodox we have seen doctrines attain new importance, and old doctrines come to be all but disregarded. We have seen theology become codified into scholasticism. The "High Calvinism" of Protestant scholasticism, mitigated, as we shall see, only slightly by covenant theology, provides the context for an examination of the teachings of Thomas Hooker, to whose works we shall now turn. 
CHAPTER III

THOMAS HOOKER'S THEOLOGY AND ETHICS, AND HIS CONCEPT OF THE ROLE OF PREACHING

An investigation of the theology of Thomas Hooker is seriousiy. impeded by the fact that although Hooker's extant works are voluminous--about five thous and printed pages in all--he left no single major work in which he presents his theology directly. The greater number of Hooker's works are sermons, either taken down by hearers and published without. his permission, or in a few cases prepared for publication by Hooker himself. ${ }^{1}$ of the remainder, one is a brief catechism, An Exposition of the Principles of Religion (London,. 1645); another is his great work on church polity, A Survey of the Summe of Church D1scipline (London, 1648); two others are prefatory epistles to works by other men: one to William Anes's A Fresh Suit against human Ceremonies ([Rotterdam?] 1633), another to John Rogers's The Doctrine of Faith (3rd ed., London, 1629). Two other works, The Immortality of the Soul (London, 16/46) and The Eqvall Wayes of God (London,

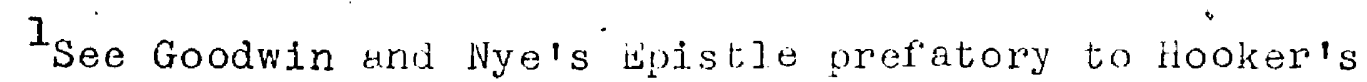
Application of Redemption: The Winth and Tentis Books itondon, -1657$)$. 
1632), are probably not Hooker's work at all, though biblin.. ographies so list them. ${ }^{2}$ Like most Purltans, Hooker was not an expository preacher; he was a practical preacher. Thus we seldom find Hooker remaining in the realm of pure theology for very long, and what pure thoology we do find is nearly always soteriological. 3

Another serious obstacle to obtaining a good idea of the basic theology of Hooker is that he shifts his approach radically without warning, addressing the already-called saints from one theological position, and speaking to the uncalled from-an apparently different position. As a result one needs always to take into consideration the context of Hooker's teachings; since he was above all a rhetorician, as Puritan doctrine demanded, the question of whom he is addressing is an important but not easy matter in determining how we are to consider what he says. For example, in the soules possession of Christ (London, 1638), Hooker indicates clearly at the beginning of the work that he is addressing the

\section{SSee Bibliography below.}

3 One exception to Hooker's general practicét is the first section of "The Soules Justification," in The soules Exaltation (London, 1638); here Hooker presents a long theological discussion--about forty-eight pages--before coming to practical applications. Hooker explains his usual method of preaching from texts in the followine fasizion: "We shall chuse such texts, in which all . . [tile] divine trutins contained in the descriptions lof the application of redemption] are expressed . . . Neither shall we medile with every particular which the several texts will of fer to our Consideration, but only handle such as concern our purpose."-The Application of Redemption: The first eight Books (London, $1656), \mathrm{p} \cdot 3$. 
already-called, asking them to seek grace from God in time of temptation. But later he warns that if we do not resist sin we will be damned: "If you will live in your sinnes here, expect to be damned with them here after." 4 To whom is this warning addressed? Three possibilities present themselves: (I) to those who regard themselves as saints, the warning being a method of exhorting them to test their election by the method of good works? or (2) to the uncalled, to exhort them to use the means of salvation, and thus become saints who can resist sin? or (3) are we rather to think that Hooker was asking the uncalled to reform while remaining "natural men"--an impossible task according to what Hooker says elsewhere? The context of the quotation makes clear that Hooker is here addressing the uncalled, declaring that if a man wishes to be released from the rule of sin, he must be converted, and if he does not win release, he will be damned.

One factor especially complicates the problem of determining the audience which Hooker was addressing at any one point in his sermons. According to Hooker, one of "The Christians Tvvo Chiefe Lessons" is "Selfe-Tryal1."5 But the process of self-trial-testing one's spiritual condition to detemine one's eternal fate--as described by Hooker is

4 soules Possession, pp. 157-158.

${ }^{5}$ See The Christians 'Pvvo Ghiefe Lessons, Viz. SelfeDeniall And Se $\overline{1 f^{\prime} e-T r y a l 1}$ TLondon, $\overline{1040)}$ 
often difficult to distinguish from the process by which a sinner is translated to sainthood. At times Hooker can and does address both the called and the uncalled at once. Keeping these factors in mind, let us look at Hooker's version of the chief events in the divine drama of Creation, the Fall, the Atonement, the Application of Redemption, and Sanctification. 6 Hooker's concept of the 'Prinity is a good starting place, for it determines--or is determined by--his whole view of the conversion process. Hooker's Trinity seems very close to being three Gods, unless we are to take, always", his descriptions of the divine Persons as purely metaphorical. In his observations on the process of creation, for example, Hooker describes how "the three Persons enter into a consultation to. set upon this master-piece" of making man. 7 "I wili create, saith the Father, and do you create, Sonne, and doe you create, spirit." 8 slsewhere we are told that the Father is first in the work of creation, " the Son first in the work of redemption, and the Holy Ghost --the deliverer of Grace-first in the process of

6Hooker's discussions of adoption in such treatises as A Comrnent Upon Christ's last Prayer In the Seventeenth of cannot be properly studied witlout an examination of the whole probiem of Puritan mysticis!l, quite beyond the scope of this study.

7 Phe Paterne of Perfection (London, Ifilf), p. 5 .

8 paterne, pp. 19-20. 
sanctification.9 Because of the peculiarities of the "personalities" of the Persons-the Father with a. case of split personality, all justice and all mercy, the Son with a tender heart for sinners--the Christian scheme of salvation was the only arrangement possible: the redemption scheme was for Hooker the only means by which God's justice could be satisfled and at the same time his mercy be magnified. 10

Another peculiarity of Hooker's concept of God is his Christology. For Hooker, Christ is nearly always thought of as the risen Christ, except in the discussions of the atonement. Nothing is made at all of Christ's human living. 11

The Fal1

Man as created by the teamwork of the l'rinity had access to" spiritual knowledge which he lost with the Fall. 12 Adam's "understanding directed what should be done, the Will Imbraced that and the Affections yeelded serviceably to the

${ }^{9}$ Soules Exaltation, pp. $135-136$.

${ }^{10}$ Soules Exaltation, pp. 286-287. On the whole subject of the Puritan attitude towards God, see Lew1s Smith, "Changing Conceptions of God in Colonial New Sngland," unpub. diss. (Iowa, 1953).

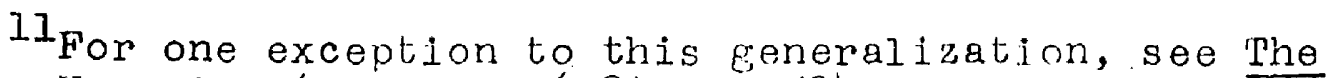
Soules Vocation (London, 1638), p. $584_{t}$.

12 paterne, pp. 54-55. 
command of Reason and Holinesse."l3 In the will righteousness and holiness were seated, and these qualities, which were not part of the will, so regulated it that man was able to perform the will of God. 14 His body likewise was well fitted to perform holy duties. 15 Adam had liberty to choose good or ev1l with equal ease, and was thus a free agent. 16 In this state of Innocence and perfection, "Adam . . represented all mankind, he stood (as a parliament man doth for the whole country) for all that should be born of him: So that look what Adam did, all his posterity did."l7 Adam of course fell, and with the Fall all men lost their liberty: for ".? . remember that Adam had liberty; and thou in him. 18

For ". - the sinne of Adam God may justly condemn all, though they never commit actuall sin... ."19 Thus ". . If we had aropped out of our mothers womb into hell and there been roaring . . It had been just."20 since the

13 Paterne, pp. 149-150.

14 paterne, pp. 62-63, 66.

15 paterne, p. 182.

16 Paterne, pp. 123 and 127.

17 The Saints Dignitie, and Dutie (London, 1651), p. 28. 18 paterne, p. 137.

19 lihe Covenant of Grace Opened (London, 364.9), p. 28. 20 paterne, p. 202. 
Fall, "All sins Original and Actual . . are punishments of the transgression of Adam, as they come from God."2l

The man with whom God now deals is "naturall man," fallen man, and the explanations of how God goes about the task of drawing men, "effectually calling" them to sainthood, must take into account the psychological processes of natural men. Since the Fall, man's nature "is stripped of all that holinesse and righteousnesse, whereby he might bee enabled to the performance of any spirituall worke, and not onely so, hee is not onely deprived of the image of God, but is altogether overspread with wickednesse and unrighteousnesse..." 22 The only relique lert after the Fall is a Iimited knowledge of the Law, enough so that man has a conscience. 23

Man's understanding was severely damaged by the Fall. "wany things wee do not know; many things that wee know, we mistake; and those things we mistake not, we see at peradventures.". Since the Fall "a natural man walkes in darknesse, or at most bixt by the starre ljght of reason." 24

But the most important effect of the Fall in nan is

2I Application: Bks. I-VIII, pp. 323-324: Pt. I, The Unbeleevers Preparing for Christ (London, 1638), 23 Application: Bks. I-VIII, n. 378-379; whe Saints Guide (London, 1645), pp. 93, Tor; principles of Religion, 24 paterne, p. 5 . 
that the w1ll is wholly tainted. 25 Although "the w1ll can embrace nothing, but what the understanding presents," it may decide not to choose what the understanding presents initially, but demand that another verdict be presented.26 Because of this relationship, man can be willingly ignorant, may try to avoid truth or make it serve his wishes, or by reason devise techniques for avoiding truth. If these techniques fail, he may refuse the truth presented as too hard for him to bear, or avoid it by running into wickedness. 27 Also, in natural man "delight and desire out-bid reason."28 In all of these changes, the inward character of the will itself is not changed, however; merely its disposition is changed because righteousness, which had been inserted into it, 'is removed, and corruption takes its place. 29

Natural men can only sin, and sin makes a man in time senseless and conscienceless, subject to worse kinds of sins, and unable to take advantage of the means of grace and salvation. 30 Man by nature is "not capable of grace, and is

25Application: Bks. I-VIII, pp. 315-317.

26 Paterne, pp. 119-120.

27 Applicátion: Bks. I-VIII, pp. 307-313. 28 Paterne, p. 160.

29 Unbeleevers Preparing, Pt. I, p. 128.

30 Application: Bks. IX $-\underline{X}$, pp. $25 / 4-259$. 
unwliling to be made capable ... . "31

The Atonement

God punished Adam and all mankind for their Fall with sin and death, but the scheme of redemption which was arranged was virtually a necessity, for otherwise kod's end in creating the world would have been frustrated, God's mercy would not have been made manifest, and ". . the Elect fallen without this could have had' no comfort." 32 The scheme of redemption was the result of conference among the Trinity. The Son agreed to "put himselfe into the roome of a sinner"; God was then to proceed against him with the Law, so that God might "justly express the power of his revenging Justice upon him . . . "33 Thus Christ the son suffered the death of his body and deathly pains in his soul, 34 and "whatsoever punishments divine justice required, or were deserved by the sinnes of the faithfull." 35 Christ died only . f'or the elect since, had He died for all, God's justice would have received two payments for the sins of the

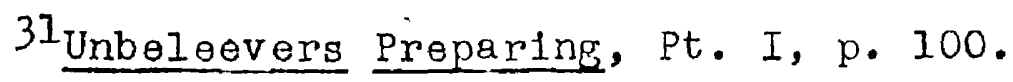

32 Principles of Religion, p. 13.

${ }^{33}$ Soules Exaltation, p. 175.

34 Soules Exaltation, pp. $210-214$.

35 Soules Exaltation, p. 202. 
reprobate: Christ's death, and their own punishments. The damned are in Hell only because God's justice demanded that they make payment for their sins, for which Christ had not paid. And further, if Christ had died for all, all would be saved. 36 .

Justification

Christ having atoned for the sins of the faithful elect, the next step in the process is justification, "an act of God the Father upon the beleever, whereby the debt and sinnes of the beleever are charged upon the Lord Iesus Christ, and by the merits and satisfaction of Christ imputed to the beleever; hee is accounted just, and so is acquitted before God as righteous." 37 The act of justification is God's act because the Father was the party offended by Adam's sin, which was directed against Him. So God the Father is the creditor, the son the surety, the sinner tile debtor, and the Holy Ghost the messenger who brings acquittance. 38 the means by wich the sinner receives the benefit of the atonement is on God's part the decree of justification, or the sinnerig part faith. "God the Father, and the Lord Jesus

36 Application: Bks. I-VIII, p. 15-19. In the seventeenth century there was, of colurse, no need to deny Universalism.

37 Soules Exaltation, p. 132 .

${ }^{38}$ Soules Exaltation, pp. $135-137$. 
Christ made a mutuall decree and purpose, that so many [as] should beleeve, they should be saved: And . . they did make a mutuall agreement . . that the Lord Jesus Christ should take the care of those soules to make them beleeve, and to"save them by beleeving ... . 39 Thus though faith is the condition of justification, God the son works the condition: ". . when the Father hath revealed, that so many in such a place shall bee saved, then the Lord Christ undertakes the care of them, and he calls at such a door; and saith, I must have that poore drunken creature, and he must be humbied, and broken hearted, and he must beleeve . . . 140

On God's part the decree of justification has two aspects: a moral change and a natural change. The first consists of God's considering the sinner in a new frame of reference: God "puts the soule into another room," into a new category, and considers him sinless. 4.1. The second consists of God's giving the soul new grace: man, obtaining new affections and desires, is changed. 42 This second aspect does not justify man. While the council of Trent maintains that a man is justified by the grace imolanted in him, and is

\footnotetext{
${ }^{39}$ Soules Exaltation, p. 170.

40 Soules Exaltation, p. 171.

$4{ }^{2}$ Soules Exaltation, p. 140.

42 Soules Exaltation, pp. 13/1-142.
} 
saved by what he becomes through grace, Hooker specifically rejects this concept and contends that man is justified only through imputation, and saved by faith, but not for faith-rather for Christ's obedience and merits. 43

Keeping in mind Hooker's concept of justification, we may well consider here a passage from the Soules Implantation (London, 1637). "So he [Christ] saith to every one of our soules, This. day I have travelled a great way for you, and have had a very hard journey; I have suffered many crosses and afflictions, many mocks and scuffs, many buffets, yea even death it selfe, for you."4t The question is, who is "you"? Hooker is speaking, apparently, either to the' saints or to all men. If to the former, why dogs he use the universal term, "every one of our soules"? If to the latter, Hooker is here inconsistent with his views of a limited atonement. Such difficulties we shall come up against in other circumstances. The answer here seems to be that Hooker is describing, subjectively, how Christ appears to the elect; He seems to offer himself to them and to all men.

Vocation.

After man has been justified, the benefits which are now his must be made effective to him through vocation:

43 Soules Exaltation, pp. 117-122. 4.4 Soules Implantation, p. 54 . 
redemption must be applied. In order of occurrence, vocation comes before the natural. change and after the moral change of justification. It serves as the means of application; in it ". . the Lord drawes the sinner from himselfe and his corruptions, and breakes that cursed league and.combination that is between sin and the soule... 1445 Then follows "the putting in of the soule.. . to lye upon, and to close with the Lord Jesus Christ... . 146 The condition needed for a man to be able to respond to the "drawing" is faith, which, as we have seen, is supplied to the elect. "The Lord, as he requires the condition lof believingl of thee so he worketh the condition in thee." 4.7 Faith Hooker defines as "a work of the spirit whereby we are inabled to apply to ourselves the promișes made in Christ for reconcillation with God." Hooker makes clear that God does not require man to believe by himself, for by nature he is unable. 49 He will not and cannot receive grace and salvation except by the Holy Ghost working in him. 50 "Howsoever a natural. man cannot receive the Lord Jesus, yetethe Lord

45 Soules Implantation, p. 83.

146 Soules Vocation, p. 33.

47 Soules Vocation, p. 4.0 .

$48_{\text {The }}$ Christians Trvo Chlere Lessons, D. 14,8 (imisnumbered $2 \longdiv { 4 }$ T.

49 Soules Vocation, p. 3ho. See also l. 331.

50 Unbeleevers preparing, Pt. I, p. 89. 
will make all that belong to the election of Grace willing to receive him ...." 151

Faith as a condition is especially important in its role in reprobation. Christ purchased "all spiritual goods" for those who shall believe and deny themselves. By demanding of men a condition for salvation which the reprobates do not fulfill, God can punish them justly, and the fact that they cannot believe is their own fault, since their inabllity is a result of the fill, for which they are responsible 52 sensing that some may regard this situation as somehow unjust, Hooker in the same treatise raises an objection to the treatment of reprobates and then answers it, to at least his satisfaction. Why are reprobates commanded to believe what is not true for them--that christ died for them--only to be punished then for falling to believe? Hooker's answer--if it may be called that--is that since reprobates cannot believe, they are not in fact commanded to believe.53 A simpler statement of Hooker's views on reprobation is this: "God justiy may and doth deny Reprobates Grace; not only because they do not what they may, but also because they do that which through the corruption of thelr hearts they

$5 I_{\text {Unbeleevers }}$ Preparing, Pt. I, p. 126.

52 Application: Bks. I-VIII, pp. 11-15.

$53^{\text {Application: }}$ Eks. I-VIII, pp. 6/1-65. 
cannot avoid." 54 This pronouncement has the merit of being far more forthright than some which we shall observe later. Since the fallen but elected man that God is to convert to sainthood is a creature of desires, God takes advantage of man's selfish nature and presents Christ as desirable to man because He will preserve and help man. 55 God appeals to all man's faculties, so that faith comes after the Mind understands it, Hope eagerly awaits it, Desire longs for it, Love embraces it, and the will will have it. 56 That the understanding be convinced and the will persuaded of the desirability of Chrigt is especially important. 57 But the intellectual process of believing is not enough, 58 for it is the will that is' "the great commander of the soule." 59 It is difficult to reconcile Hooker's attitude in The Soules Vocation that the will'must be persuaded, with his statement in the later Application of Redemption that the will does not in itself have the power to will grace, but must have supernatural power put into it, and that the power of corruption, which has ruled the will since the Fall, must be removed by "a holy kind of violence"; according to this

$54_{\text {Application: }}$ Bks. IX $-\underline{X}$, p. 308.

55 Unbeleevers Preparing, pt. I, pp. 32-33.

56 Soules Vocation, pp. $283-284$.

57 Soules Vocation, p. 289.

58 Soules Vocation, p. 35.

59 Soules Vocation, p. 283. 
explanation of conversion the will itself is not violated since it is powerless. 60 If this is the situation, one $f$ finds it difficult to see how the will can be persuaded. If we wish to believe that Hooker was consistent, perhaps we can explain the seeming contradiction in the following fashIon. God appeals to the corruption which rules the will, basing His appeal on the soul's selfishness. Although such an appeal is not in itself sufficient, according to Hooker, for "effectual calling," it is nevertheless a necessary preparation for salvation. God's work on the will, in this explanation, is comparable to Hooker's description of God's work on the reason: before giving new power to the soul, $\mathrm{He}$ makes a "moral kind of drawing" in appealing to man's reason. ${ }^{61}$ This explanation is also consistent with two of Hooker's descriptions of the conversion process: the process, that is, which culninates in effectual calling. Both descriptions are, taken from The Application of Redemption, a work which Hooker prepared for the press. 62 In the first, Hooker writes:

- manie a Saint of God can say that the Lord hath been wrasting with him from the time of his Chlldhood, and all, along in the places where he lived somtimes strange horrors and strokes of consclence, and strange sins that he fell into somtimes $\underline{B k s} . \underline{I X}-\underline{X}$.

60 Application: Bks. I-VIII, pp. $373-382,385$.

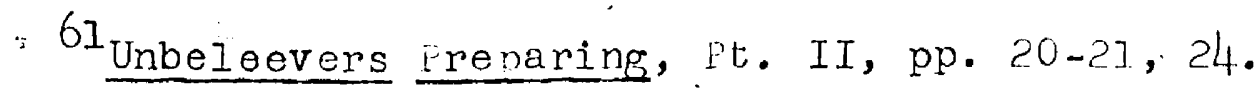
${ }^{62}$ See Goodwin and Nye's Epistle in the Application: 
and then strange humiliation and abasement for this, Grace is not wrought yet thats true, but its workIng, the Soveraigne vertue of the blood of Christ is now at. work, and will never leave the soul for which Christ died until [sic] there be a full and effectual application of all saving good.... .63

It is to be noted that Hooker makes clear here that the humiliation and strokes of conscience which prepare the soul for conversion are just as much God's actions as is the ef- fectual calling itself.

According to a later passage in The Application, God first lets the soul see that it is not in the way of salvation, then lets it see His mercy, Jesus's sufficiency, His patient watting and entreating. If these do not convert the soul--and from what we have read they. cannot be expected to do so--God then makes the conscience work, stirs it up, and admonishes the soul. 64 But satan fights back.

The World by her Allurements, Satan by his Temptations, and the accursed delights of our sinful lusts, they al beseige the soul, and by their wiles perswade the sinner to joyn sides with them, and not to be awed or carried away by any contrary command: these be (say they) threatenings announced, but threatened men live long, this wind shakes no Corn, this is no way of policy to scare men, but it is not in earnest to hurt men, the same has been spoken to others, but nothing inflicted upon them, they never found, never. felt any such sore blows as al tilose terrible shakings of the rod pretend. Thus the sinner is yet drawn aside to follow his sinful courses: Consclence therefore makes after him, lales violent hands upon, and holds him faster than ever; he be- comes now an accuser of him, who was only a friendly

\footnotetext{
63 Application, Bks. I-VIII, p. 79. 64 Application, Bks. I-VIII, pp. $355-365$.
} 


\section{admonisher before.}

The soul is then called back to its sinful course yet another time, and as a result God declares, "Let him perish in his sins, for he has rejected mercy." The soul now sees its condition truly. Then God plucks him out of sin and calls him to sainthood. 65

According to this description, God's grace seems to be irresistible mainly because $\mathrm{He}$ is an expert psychologist. "Effectual calling" is effectual at least partly beckuse of God's nice sense of timing. If one asks how it is that God announces that $\mathrm{He}$ will permit the mercy-rejecting sinner to perish, only to "effectually call" the sinner later, the answer would seem to be that this description is a subjective view of the process: it is psychologically valid if theologically confusing. Students of Puritan "experimental theologians" such as Hooker would do well to consider that such preachers often attemut descriptions based on the appearance of the conversion process from man's roint of view. Once argin we see that grace is irresistible rrom a theological point of view though man regards himself as free throughout the process. In context, preparation for salvation is God's means of making $H i s$ irresistible power apyear to man to be merely persuasive. And indeed, saving grace actually does work partiy through persuasion, which thus becones a rieans

\footnotetext{
65 Application, Bks. I-VIII, p. 367. see ilso the description in The saints Guide (London, 161,5$), 20.23-1.10$.
} 
of salvation. The process which is from an objective point of vlew strictly predestined is likely to appear to man to agree with the Arminian descrintion.

\section{Sanctification}

As a result of vocation and justification, man is "adopted and sanctified," 66 or rather, begins to be sanctified. But

. the frame of the heart in vocation is not the
frame of the heart in sanctification. This Call and
vocation in the Lord workes upon mee, and I have no
power in myselfe, but I can only receive power from
another.
the power of grace, that I have formerly received by
the spirit in the work of adoption. 7 ?

To receive the power of grace, ". . the Lord Iearnes every faculty his lecture... "68 As a result, ". . no f'aculty of the soul, but it should be adorned with some glorlous impression of the power of Grace, wisedoin and prudence

66 Hooker is not always consistent about the order of the steps. Perhaps justification should follow vocation, according to the following convenient description: ". . In vocation the Lord drawes the soule to himself'e, and the soule follows him; in justification the Lord undertakes for the sinner, and unftes the soule to himselfe, and makes it one with himselfe; in adoptjon the Lordmakes him a sonne, and in sanctiflcation he sets a stampe upon him."--Soules Implantation, p. 137. The order of justification and vocation does not seem to have been an important noint to Hooker. 67 Soules Implantation, p. 157 . $68_{\text {Soules }}$ Vocation, p. 202. 
in the mind, holiness in the will, harmonious readiness in

al the affections, to attend the counsels of the Lord, to be the instruments of holiness."69 All saints receive a "heart of flesh" which will do whatsoever the Lord commands.70 Indeed, the saint is above Adam's excellence and Innocence, since he is "wholly taken up with God in Christ."7l This new relationship is "adontion," one of God's purposes in conversion.

But although the soul is "subject to grace," actually ruled by grace, 72 Hooker makes clear-that he scorns the doctrine of the "cursed Familist" sect, which held that the truly converted soul cannot sin. 73 It is up to the saint to ask for grace to resist temptation and avoid sin. He must say to God,

- . by that spirit of wisdome, Lord informe mee; by that Spirit of sanctification, Lord cleanse me $\theta$ from al my corruptions; by that Spirit of grace, Lord quicken and enable me to the discharge of every holy service, thus carry thy selfe and convey thy soul by the power of the Spirit of the Lord, and thou shalt finde thy heart strengthened and

${ }^{69}$ Christ's last Prayer, pp. 89-90.

70 Unbeleevers Preparing, Pt. I, p. 131.

7 Christ's 1 ast Prayer, p. 45.

164.5), ${ }^{72}$ A brief Exposition of the Lords Prayer (Londion,

73 For Hooker's scorn of the l'amily of "Love, see, f'or example, Soules Exaltation, p. 190; Soules Vocation, p. 65; Soules Implantation, pp. 232, 230; saints pienitie, p. 131; and A survey of the summe of Church Discipline TLondon,

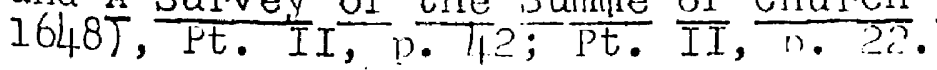



succoured by thy vertue thereof upon all occa-
slons. 44

But the more grace a man is given by God, the more God expects of the recelver, 75 and grace is given according to need. A family man gets more than a single man; a magistrate or a minister more than a layman. ${ }^{76}$ But although he must go to Christ daily to ask for grace, 77 man may not be able to detect the grace given, a ccording to Hooker, and then one should "labour to see sound evidences of the work of grace in thy soule... . "78.

But despite these difficulties, the process of sanctification is progressive, and continues, with interruptions and setbacks, until death. 79 This gradual process Hooker describes as being similar to the repairing of a clock. It is "not a making new faculties in the soules but putting them into right order; as when a clock falls into pieces (the wheels not being broken) the clock hath not new wheels set into it, but they are new made againe." 80 Although the

74 soules Exaltation, pp. 111-112. See also The Soules Possession of Christ (London, 1638), pp. 7-8.

75 The Faithful. Covenanter (Lond n, $16 / \mu_{t}$ ), p. 17. 76 Soules Exaltation, pp. 69-71.

$77_{\text {Soules }}$ Possession, pp. 29-30.

78 Soules Vocation, p. 633.

79 Saints Dignitie, p. 62.

${ }^{80}$ principles of Religion, p. 2h. Compare Covenant of Grace, p. 31 . 
saint is superior to Adam in that his relationship to God is of a higher order, he is not to expect to be able to live as virtuous a life as Adam could have led. 81 For though in the saint sin is not a king, "it may be a Tyrant." 82 The reason for this situation is that the "old man" Adam in us is not wholly dead, and man tries to keep him alive. 83

When Hooker declares, therefore, that a saint "had rather endure the torments of hell, then that the least sinne should be committed by him," 84 we are to understand that Hooker is not stating a fact, but is rather exhorting the saint to act as he should. The role of good. "works is very important in Hooker's thought. Besides their conventional role in Puritanism as a means of testing one's calling, Eood works have, according to Hooker, other inportant us es. In particular they serve as a means of achieving a closeness to Christ, 85 and as a means of glorifying God 86 and rewarding Him for His goodness to the saint. 87 And, "Though moral vertues will not save a Christian, yet without them no man

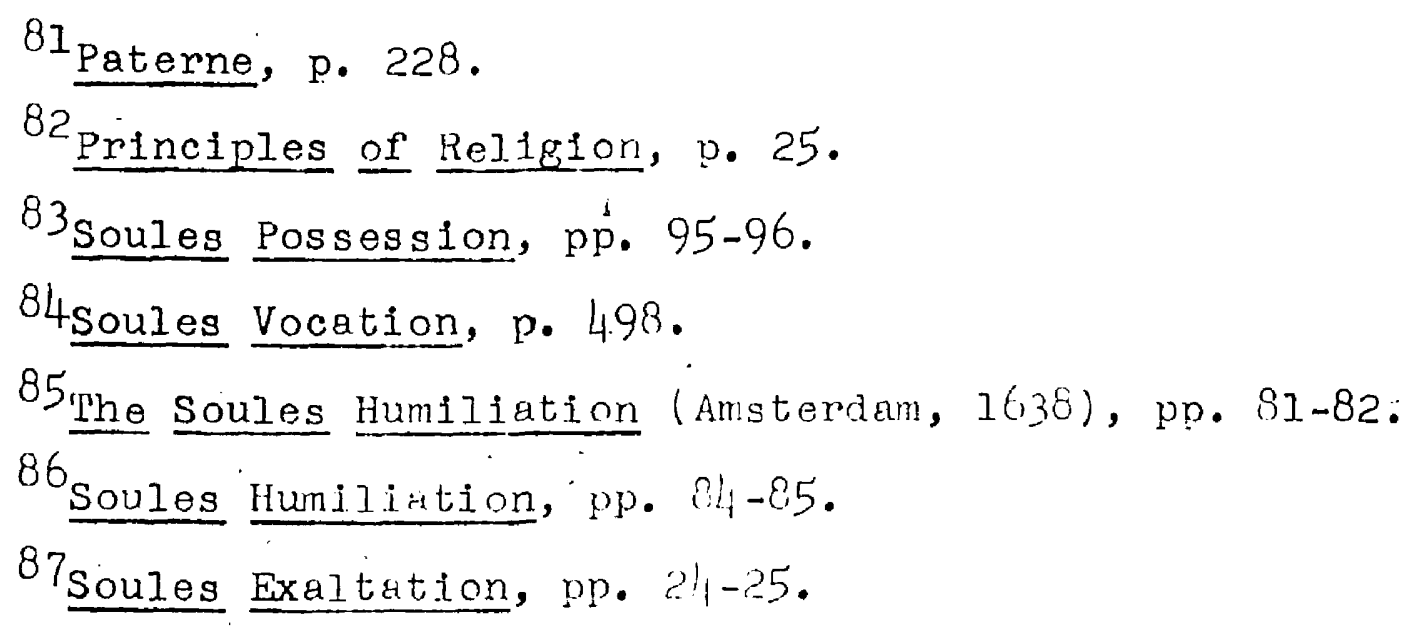


shall ever come to heaven. $" 88$ We may juxtapose here another quotation from Hooker in order to illustrate once again how Important it is to consider the audience Hooker was addressing. "The Saints of God," Hooker declares to the unconverted, "shall commit greater sinnes and goe to Heaven, when thou lesser and goe to Hell." 89 The statement sounds like a flat contradiction of the preceding quotation. But while the former is an exhortation to the called saint not to rely too much on justification by faith (since man is saved by faith, one may question why he should not do so), the latter is a warning to the uncalled not to rely on good works as a means of salvation.

\section{Morality}

Although Hooker's works are full of exhortations to cood works, one is surprised at how'seldom Hooker gives his reader any idea of what constitutes the good life. Vague descriptions of aspects of piety are not, however, hard to find. For example, in the section of the paterne of perfection entitled "The Character of a sound Christian in seventeen markes," Hooker lists mourning for sins, endeavoring to eliminate sins, delighting in prayer, rejoicine in God's word, loving good Christians, and hatine the wicked. From

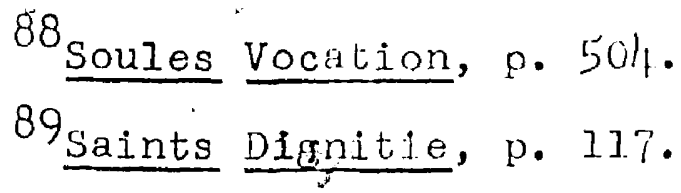


this we may get a good Idea of what Hooker regarded as works of piety. But lists of moral virtues are more rare, and Hooker's lists of sins include mainly the grossest variety: one list mentions dmunkenness, adultery, blaspheming, condemning God's ordinances, railing on God's saints, despising God's truth, and profaning the Sabbath. 90 At, least throe of . these sins would seem to be best classified as religious shortcomings, rather than moral vices, if such a distinction may be made. Another list includes only such sins as Sabbath-breaking, swearing, adultery, and drunkenness. 91

More often Hookex's discussions of Christian ethics are such as to make the modern reader suspect Hooker of being almost a moral Pharisee. The following quotation, from the Saints Guide, is a choice example:

I must preferre my own occasions before another mans, my goods before his, my body before his, serve my selfe in the first place, and my neighbour in the second, but I must not prefer my body before his soule, my temporalls before his spiritualls, nor my goods before his $11 \mathrm{fe} .92$

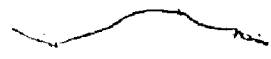

In Fovre Learned and Godly Preatises, Hooker declares charltably,". - the soules of all men should labour to doe good unto all, so farre as necessity require it and

90 Unbeleevers preparing, Pt. II, p. 58.

${ }^{91}$ Saints Dignitie, p. 178 .

92 Saints Guide, p. 160 .

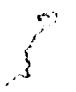


- opportunity is offered there unto . . . "93 Although this may seem limited enough, we learn later that doing good to all consists, according to Hooker, in getting men on the path ta salvation. 94 In another work, Hooker leads the reader to believe that he is about to discuss some basic ethical principles. But after general statements to the effect that men should promote the good of their fellows Hooker becomes more particular and cites an example of how we can help our brethren: we should keep them from sin. 95

In a few discussions Hooker does, however, deal with practical morallty, though the matters are usually mentioned only in passing: he condemns taking a penny or a shilling too much, selling marred goods by sleight of hand, goldbricking in the older sense of the term, and outbidding "a man in a bargain by a wile, and he never the wiser."96 In " another discussion we are told that a man should obey his master even if his master is a carnal man. 97 But more often Hooker reduces his ethical principles to one tenet: help uthers to be saved. 98

93 Fovre Treatises (London, 1638 ), p. 65.

94 Fovre Treatises, p. 65.

95 paterne, pp. 102-104.

96 Apulication: Bks. IX-X, p. I68.

97 Soules Vocetion, p. $50 \%$

98 For example, A brief itxosition of tire Lords prayer (London, 1645), p. 1,7. 
The two cardinal sins for Hooker are surely pride and hypocrisy. Among the bright spots for the modern reader of Hooker's works are his psychological descriptions of types of hypocrites; these brief sections are closely related to the seventeenth-century genre; the character. Here is Hooker's description of a type that combines hypocrisy and pride, the "self-conceited Pharisee." He

hath such an overweening apprehension of his own worth and excellency, that he is not able to take shame for his sin, \&, therfore cannot endure to. be convicted of it, what he wil not do, he wil not know, loth to confess his course shameful and vile, because then he concludes there is no color of common sense to continue in it, but he must be forced to.reform it, unless he would openly proclaim to all the world, that he is resolved to go against knowledg and Conscience, which is too loathsom and gross, even to ordinary profanenesse; therefore he pretends nothing but the search of the Truth, and further information of the mind of the Lord, and if that once would appear, how glad would he be to receive it, and more glad to follow it because the plea is beyond exception, yea, carries an appearance of consciencious and judicious watchfulness in a mans course, which cannot adinit a Cavil, but is secretly resolved of the Conclusion, the reasons shal never be plain to him that would press and perswade to the practic $\theta$ of that which doth not please gis sensual hoart, which he purposeth to satisfie. 99

Other types" of hypocrites that we meet in Hooker's works include the wrangling hypocrite, the whining hypocrite, the vainglorious hypocrite, and the presumptuous hypocrite. 100

99Application: Bks. IX-X, p. 4.23.

100 Soules Implantation, pp. 219-24/4. Hor other descriptions sea Soules Vocation, pp. 164-182, 277-282; and Soules lixaltation, pp. 18-20. 
Hooker's attacks on pride, though not in the form of characters, often have literary merit because the subject seems to have stirred him to real eloquence. 101

A few words may well be said here concerning the relationship of the uncalled to good works for Hooker. Although he often argues strenuously that every sinner is in a state of slavery to sin, 102 he often seems to urge the uncalled sinner to reform as a means of preparing for salvation. In these passages he often appears to the modern reader to speak as we expect a Puritan to speak. We read that ".. • the Lord saith, thou must forsake thy sins, orvelse I must damn thy soul." Again, ". . either I must lose my sin or my soul, there is no other thing to be done."103 But one is never quite sure in dealing with these passages whether Hooker is urging the saint to forsake his sins, the as-yetuncalled sinner to use the means available by which he might forsake his sins--that is, through the sanctification wich follows effectual calling--or perhaps the natural man to use common or restraining grace, in which Hooker, like Calvin, believed. ${ }^{104}$ man cain never forsake his sins by himself, accordine to Hooker, and so when he warns, ". . . if you will

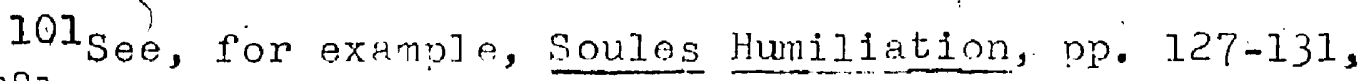
$266-281$.

102 see, for example; Unbe] eevers Preparing, Pt. II, p.8. 103 Saints Disnitie, pp. ilu-zhi.

${ }^{104^{S}}$ See Christians Lessons, I. 11/ (misnumbered 21/).
} 
have sinne dwell in your soule, God will never dwell with you, nor you shall never dwell with him,"105 he is here encouraging man to want to forsake his sins, for ". . If a desire unto sinne be the sinne itself before God .. Why shali not, much more an earnest desire [f]or the pardon of sin be an obtaining of it? An earnest desire to beleeve be accepted for belief it selfe?"I06 This may sound like mere" sentimentality or an attempt to substitute sweet reason for irresistible grace, but we should remember that "an earnest desire," according to Hooker's teaching, is a sign of election.

Preaching

The role of the preacher is crucial. In Hooker's view of the salvation process. Although at times he appears to believe that the preacher has the power in himself to save sinners merely by using the right technique, 107 more often the preacher is regarded merely as God's instrument. Preaching is thus "like a Burning-Glass; that which burns

105 Fovre Treatises, p. 252 .
106 Christians Lessons, p. $1 / .9$ (misnumbered 2/49).
107 In the Soules Implantation, for eximlle, appears the following passage: "If the ministery of God were dispensed as it should [be], it would be as effectuall. as it ever was, It would worke salvation. But where lies tine fault? Alas, that lietin with the ministers of God, who doe not performe the worke of the ministery as it should [be done], and with the power they ought." - - p."73. 
and heats is not the Glass, but the beams of the sun that pierceth through the Glass." 108 But although the preacher is only a tool, he is a necessary one, for "Faith cometh by hearing . . [since] the word preached doth evidently reveale truths to the soule, and works more effectually upon a mans heart" than mere reading of the Bible.. 109 If a man wants to come to Christ, it is because of what he has heard preached; and in addition to providing motivation, preaching provides the sinner with knowledge of how to come to Christ and thereby be saved. How is a man to obtain grace? "The Lord hath vouchsafed it to none, but to those that do seek it in his ordinances; it is to be had by the preaching of the Gospel of grace."110 "Grace h'ath sent meanes, grace hath continued means, grace hath given us.hearts to use the means, all is grace, nothing but grace..."lll Thus the preacher teaches men what the means of salvation are; such a situation is made possible by the fact that the spirit, which enables man to desire and use the means, is communicated by preaching: ". . . the work of the spirit doth alwayes goe with, and is communicated by the word." 112 . The preaching of

108 Application, Bks. I-VIII, p. 134 .

109 Princlples of Religion, p. 27.

110 paterne, p. 280.

$111_{\text {Unbeleevers }}$ Preparing,Pt. p. Q This and the preceding quotations appear to me to be key quotations in the study of Hooker's thought.

112 Soules Vocation, p. 45. 
the Scrlptures and the Holy Ghost, always together, are God's means of conversion, but only, of course, to the elect, for ". . the Spirit of the Lord God!. Is there in an extraordinary manner, and hardens the hearts of the repro- . bates, and humbles, and converts the soules of his servants -..."113 "The same dispensation of the word which is. powerful and profitable to some is unprofitable to others."1l4 God "may send his Gospell and meanes of salvation to one poore soule... and not to another..."115 The word of God may have opposite effects on different people, for, if God wishes, it may harden a man's heart. 116

Therefore, if a man has lived for a long time under an effective minister, and has not been prepared, it seems likely to Hooker that God does not want him to be prepared II7 and "will never bestow any saving Good upon that soul."118 If a minister tells the people what steps to take for salvation, and they take them, it is because God enabled them, and enabled thern because they are of the elect: ". . the Lord will make all his that belong to the election of Grace

113 Soules Exaltation, p. 2\%. See also pp. 35-36. 114tApolication, Bks. IX-X, p. 283. 115 Unbel eevers Prenarine, Pt: $\mathrm{T}$, pp. 9-10. 116 Soules Implantation, pp. 7l-72.

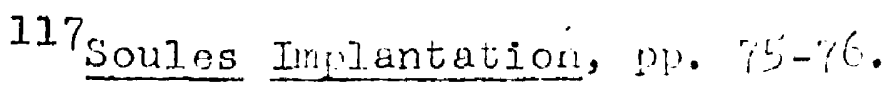
118 Aonlication, Bks. I-VIII, nn. 2183-2I\%. 
willing to receive him... . "ll9

To this last quotation let.us juxtapose another from the same work; this second quotation will help to show Hooker's attitude towards the role of preaching, and also give an insight into the previously discussed problem of the point of view from which Hooker means for his readers to look at a passage (or his hearers to understand 1 t). This time a careless reader or listener might regard the passage as an invocation addressed to man's natural abilities.

- - God stands this day \& knocks at this and all other the like opportunities, the Lord knockes this day, and will. come and knocke againe the next sabbath, and the next, the next Lecture, and the next opportunity, when the minister comes God comes, when he persuades God persuades, when hee threatens God threatens, when he reprooves God reprooves, sometimes the Lord knocketh at the doore, sometimes hee pickes the locke, thus every way striving to come in, stands thus knocking, and intreating, exhorting, perswading, he knocks with much patience and long suffering, if any man will but open, here is all the Lord requires, all that he expects and lookes for, the opening of the doore that is all . . .120,

After realing the quotation presented immediately before this passage--to the effect that the Lord makes the elect willing to receive him--one may regard this passage as an example of Hooker's demanding the impossible. How can man open the door by himself? The answer is, of course, that he cannot. But those who desire to do this impossible deed

\section{Unbeleevers Preparing, pt. I, p. Icl. 120 Unbeleevers Preparing, Pt. I, pp. 27-28.}


w1ll ask for and recelve grace to permit them to do it, as Hooker elsewhere directs them to do. This is simply the way that God arranges the situation: "God doth not punish a man because he cannot get faith, but because he will not use the meanes whereby he might get faith, we may waite upon God in his ordinances..." $" 121$ Therefore when Hooker describes God as knocking at man's soul, imploring him to be saved, he Is accurately reporting how conversion appears to man: this is the way God wants man to regard conversion. If you are willing to be saved, that is a sign that God intends good. He who is willing, will use the means. If man desires to be exhorted or reproved, good. If he is willing to part with his sins, it is because grace works within him, and the willing will result in the soul's parting from its sin; it cannot be content to have it otherwise. 122

One of Hooker's fullest descriptions of the role of preaching in the salvation process is in the survey of the Summe of Church Discipline. Here a number of details are Given concerning how the preacher leads the soul to conversion. But we must renember in reading them that preachers are at most "Co-workers with the sonne.. . to bring the poor creature, and his creator together."123 And the preaching of the word is an "instrumental cause of

$$
\begin{aligned}
& { }^{121} \text { Unbeleevers } \\
& 122 \text { Preparing, Pt. I, p. 1.2. } \\
& 123 \text { Splication, Bks. I-VIII, pp. 335-345. }
\end{aligned}
$$


application" only because the word is accompanied by the, presence and operation of the spirit. 124

Among the preacher's functions are:

- . to work upon the will and affections, and by savoury, powerfull, and affectionate application of the truth delivered, to chafe into the heart, to wooe and win the soul to the love and liking, the approbation and practice of the doctrine which is according to godlinesse ....... . . to lay open the loathsome nature of sinne, and to let in the terrour of the Lord upon the conscience, that the carelesse and rebellious sinner may come to a parley of peace, and be content to take un the profession of the truth. - . to discover the cunning fotches of the hypocrite, and to hunt him"out of his mises, that he may not cosen himself and sit down with some reserved delusion, and go no further. To censure all those feares, and to scatter all the clouds of discouraging objections, that the soul may see the path plain and safe to come to the promise, and to receive power and comfort to walk. with God therein. 125

Hooker recognizes clearly that since the preacher is dealing with fallen man, appeals to the understanding are not enough: he has to anpeal as well to the affections of fear and love; and to the will. But his aim is to restore man's faculties from the dislocation--wich resulted from the Fall --to their proper relationship with reason at the helm. For from the psychological polnt of view, conversion is simply getting the clock to start working properly again, to use Hooker's image. As Hooker puts it, ". . . if thou art not

124 Application, Bks. I-VIII, p. 133.

125 Survey, Pl. II, pp. 19-20. 
$h$

another man than when thou camest into the world, thou art but a natural man, thou art but a damned man." 126 .

After conversion, the role of the minister is to exhort the saint. to achieve assurance of salvation through rigorous testing, and "to' quicken . . strengthen and incourage the soul in every holy word and work."127

The Puritan was taught to look to the minister for the means of salvation: ". . we must not looke for revelation and dreames, as a company of phantasticall braines doe . . In common cause God's spirit goes with the Gospel, and that is the ordinary meanes whereby the soule comes to be called."128 God has indeed tied Himself to the gospel as the means of salvation. 129 It was altogether natural that Hooker, and other Puritans whose great interest was in the technique of preaching by which men are saved, would try to develop a detailed analysis of God's process in the application of redemption. We shall look at aspects of Hooker's analysis in the next chapter.

126Application, Bks. I-VIII, p. 297.

127 Survey, Pt. II, n. ?o.

128 Soules vocation, p. 3 .

${ }^{129}$ Soules Vocation, p. it. . 


\begin{abstract}
CHAPPER IV
HOOKER, COVENANT THEOLOGY,

AND THE SERIVON AS THE MEANS OF GRACE
\end{abstract}

within the last twenty years the New ingland theology of the seventeenth century has been examined far more closely than it had ever been before, and the flindings have been that this theology is very different from the simple "Calvinism" which earlier students of the period had labelled it. ${ }^{l}$ Perry Milier, the princlpal worker in the field, discovered that the New England theology was really "Covenant Theology" and has declared that this is very different from... "Calvinism." 2 others have readily accepted his findings. That such a thing as covenant theology exists was

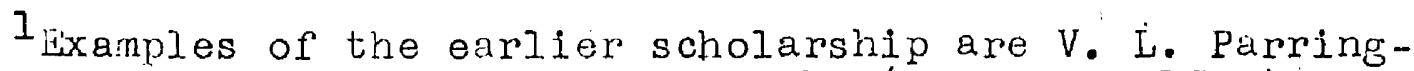
ton, Main Currents in American Thought (New York, 1930), I, 12.-15; and F. H. Foster, A Genetic History of the New singland Theology (Chicago, 1907), p. 15 .

${ }^{2}$ Milzer's main discussions on the subject are "The Witrrow of Puritan Divinity," Pubs. Col. Soc. L.ass., llransactions, 1933-1937, XXXII ( 1938$), \overline{247}-3 \overline{00 ;}$ line Ivew England Mind: 'The Seventeenth Century (New York, 1939 ; Cambridge, liass., 1954), hereafter cited us Seventeentir Century; and The New England lind: From Colony to Province TCambridge, Nass., 1953), hereafter citer as Colony to province. See also his "The luritan Theory" of the sacranents in Seventeentr-Century New England," Catholic Historical Review, XXII (1937), luy-1.25; and "reparation for jalvation in Seventeenth-Contury liew ungring," Joumal of tile ijstory of Ideas, IV $(19 / 13), 253-256$ 
scarcely a new discovery, though Willer's discussion and special bibliography of the, subject ${ }^{3}$ might make one think that he had been exploring an unknown territory and had come back with new findings. Such a general study as James 0rr!s article "Calvinism" in the Encyclopsedia of Rellgion and Ethics reveals that covenant theology was one of the three fundamental developments in the Reformed theology after Calvin's death. In the same encyclopedia the article "Covenant Theology" by W. Adams Brown points out that covenant theology developed in English Puritanism as a parallel movement to its growth on the Continent. Brown cites Perkins, Ames, and Preston as examples of English covenant theologians. E'ven in the last century the German scholar J. A. Dorner had pointed out exactly what willer maintains: that covenant theology tended to undermine predestinarianism. 4

Our study will proceed in the following fashion. First, we shall see what covenant theology is. Second, we shall try to determine the degree to which covenant theology differs from the theology of Calvin in its approach to the conversion process. Third, we shall try to determine the extent to which the teachings of Thomas Hooker can be described as covenant theology. This discussion will necessitate a

\footnotetext{
${ }^{3}$ In Seventeenth Century.

4 History of protestant Theology, trans. G. Robson and S. Tay Ior (Edinburgh, I871), II, 41-l,2. Dorner (II, 43ff.) also shows that covenant theology was opposed by orthodox
} Reformed writers. 
detalled analysis of Hooker's techniques in conversion preaching, a discussion which will be continued in the next chapter.

Covenant Theology: its History and Central Tenets

Historically, covenant theology stems from Calvin's predecessor Zwingl1, author of De Testamento seu Foedere De1 Unico et eterno (1534); It was taken up later by such Important Reformed theologians as Bullinger; Ursinus and 0levianus, authors of the Heldelburg Catechism; Junius; and afterwards by Ames and Cocceius. 5 Cocceius formulated his. theology more completely on covenantelines than any earlier theologian and is regarded as the greatest covenant theologlan. Calvin himself, like many other Christian theologians, spoke of a divine covenant, but because the covenant is not a basic element for his system, he is not regarded as a covenant theologian. 6

${ }^{5}$ See Gottlob Schrenk, Gottesreich und Bund im Hlteren Protestantismus (Glltersloh, 1923), passim; Peter Y. De. Jong, The Covenant Idea in Now England Theology (Grand Rapids, 1945), pp. 23-31 (unfortunateIy an unsatisfactory book); and Alexander Mitchell, "The. Theology of the Reformed Church with Special Reference to the Westminster Standards," In Report of Proc., 2nd Gen. Counc1l of Presbyterian Alliance (PhIladelph1a, 1880), pp. 474-484. L. J. Trinterud has argued persuasively that in England covenant theology goes back to Tyndale and John Frith. See his "The Origins of Puritanism," Church History, XX (1951), 37-57.

6 Schrenk, Gottesre1ch und Bund, pp. 44-45. 
The fundamental concept of covenant theology is well and simply set forth by Bullinger:

God, in making of leagues, as he doth in all things, applieth himself to our capacities. . . And therefore, when God's mind was to declare the favour and good-will that he bare to mankind . . It pleased him to make a league or covenant with mankind.

Bullinger goes on to say that this covenant was first made with Adam after the Fall, then with Noah and lioses. The terms of the agreement were, on God's side, the promise of His Son, through Whom would come complete reconciliation and heavenly blessings; and on man's side, "faitin and due obedience." Christ finished and fulfilled this old league and made a new one. In this, man is asked only for "faith-and charity," and "holy and wonderful 1jberty is given unto the $\operatorname{godly} \cdot " 7$

There are three noints of this covenant plan to be emphasized. First, God was willing to consider man's abilities. As A. C. McGiffert puts it,". . the covenant theology laid stress upon His historical deal ing with men first in one way, and then when that "railed, in another." 8 second, the new relationshin is an agreement between God and man, not a decree. Tirsinus rofines the jillistian covenant

7 Decades, ed. Thomas biling (cambridie, ung , 1850),

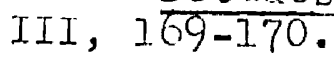

8 protestant Phought Before Kant (Nev York, 1911), p. 153. 
a mutual pactio between God" and men, by which God assures men that He w11l be favorable to them, w111 remit sins, bestow new righteousness, the H. Spirit [sic] and Iife eternal through and because of the Son the Miediator. In tum men bind thernselves to God to believe and to repent, 1.e., to recelve with true faith this sublime benefit and to afford God true obedience. 9

Third, predestination does not play so important a role as is usual in Reformed theology. The emphasis is on man's role, since God, in making the covenant, "has promised the whole of humanity, so far as it accepts His grace with penitence and trust, righteousness and eternal life as an inalienable inheritance of grace."10 Heinrich Hepre points out that the concept of the covenant of grace is thus established on an "essentially unfversalistic basis."1l. such a situation is made possible in covenant theology because another covenant exists besides the covenant of grace: a covenant by which God "graciously fulfils the condition required in those whom He has assigned to Christ rrom eternity."12

Covenant theologians, at least in purely doctrinal

9 Ursinus, Explicationes Catacheseos (Heidelburg, 1612), p. 99; quoted by Heinrich Heppe, Reformed jogmatics, trans. G. T. Thomson (London, 1950), p. 382.

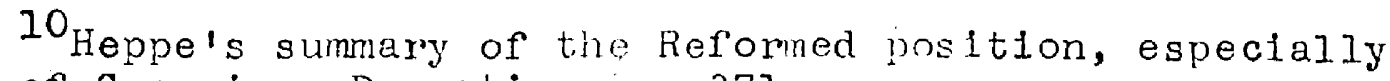
that of Coccelus, Doprnatics; r. 371.

$1 I_{\text {Dogmatics }}, \mathrm{p} .371$.

12 Eglin, De Foedere Gratiae (Harburt, 1614), p. 43, quoted by Heppe, Dopmatics, !. 372 . 
works (as distinguished from "practical" works--sermons), make clear that man is able to enter into the agreement with God only when God supplies the means: "Before grace supervenes, man has nothing by which to raise himself. . . Hence it is clear that by grace alone is man drawn to the covenant and to the grace or friendship with God."13

The Covenant of Grace was first established after the Fall--after the Covenant of Works had been violated. According to the Continental theologian Wolleblus, who was very influential in New England, 14 the covenant was first administered in the form of the old Testament: "in the time of Christ to be exhibited"; "the New Testament is the covenant of grace administered after Christ has been exhibited."15 However, Hiller gays that for Puritan theologians, the new covenant was first proposed to Abraham. 16

The Implications of Covenant Theology

Covenant theology, though it originated in the sixteenth

13 Cocceius, Opera, VI (Amsterdam, 1673), 212-214, quoted by Heppe, Dogmatics, , 1388.

14 Miller, Seventeenth Contury, pp. yo, 190.

15 Wollebius, Christianae lheologiae Compendium (Basel, 1626), p. 23, quoted by Hopre, $\frac{\text { Doginatics }}{1.395 .}$

16 Seventecnth Century, pe 3\%7. Mill implies tilat all covenant theologians regarded Abraham as une first to be within the covenant of grace. This interluetation is clear-

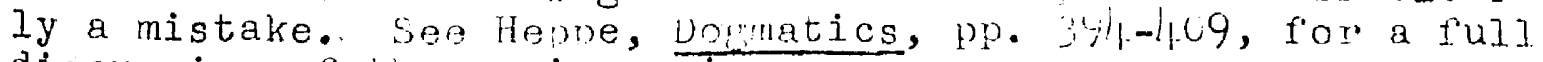
discussion of the various viens. 
century, flourished in the seventeenth as a reaction against the abstractions of Reformed scholasticism, 17 and as a defense against the Arminian attack on predestination. 18 By using the covenant idea, theologians shifted emphasis from the eternal decrees of God to God's relationships with man, without abandoning predestination. 19 In addition to these historical causes for the flourishing of covenant theology, Miller has proposed that

It almost seems as though Puritin theologians, having dwelt for years upon the implacable rigor of divine justice and being forced. . to present sovereignty as the dominant attribute [of God], were intensely relieved to come upon the covenant doctrine as at last something tangible to adduce in ploading that God was also eracious. 2

Although viller has taken pains to qualify with an "almost" this explanation of the Puritan interest in covenant theology, by Implication he is contending that earlier Puritan divines had presented sovereignty and rigorous justice as God's essential'qualities. Doubtless isolated examples of such presentations could be pointed out, but earlier puritan sermon literature is, in general, quite differont from what iviller suggests: the difference betwoen earlier and later

17 Dorner, History, II, 31 .

18 Frederick E. Pano, Jr., "Studies in the Origins of unglish Arminianism," unpub. (i) iss. (Harvard, 19,50), pp. 160 161 .

${ }^{19}$ McGiffert, Protestant Thought, p. 155.

${ }^{20}$ Seventeenth century, r. 381. 
Puritan preaching--if we wish to find ons--is that earlier preachers put less emphasis on man's inability and predestination than did seventeenth-century Puritans. 21

It is not difficult to dis cover what kind of logic led Milier to his explanation, but since the point has been made only obliquely up to now, 22 it deserves to be stated here. willer has traced with some care "the expanding limits of natural ability" in seventeenth-century puritan preaching from Hooker and John Cotton to Increase and Cotton wather; 23 he has proved, it seems clear, that the late seventeenthcentury divines expected more of man's spiritual abilities than did the first generation of New England preachers. What could be more natural, then, than to assume that puritan preachers before Hooker and Cotton expected even less of man? But although illier is doubtless correct in thinking that seventeenth-century Puritan theology would have been more rigorous, would have expected less of man, if covenant

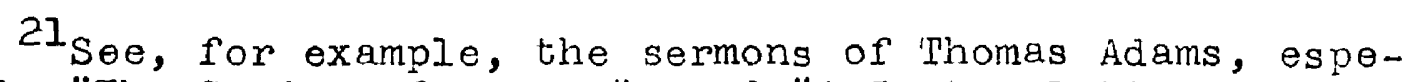
cially "The Garden of Graces" and "A Contemplation of the Herbs," both first published in 1616; and "Physic from Heaven," first published in 1614. All three were republished in The works of Thomas Adams (Edinburgh, 1862).

22 See wayne H. Christy, "fohn Cotton: Covenant Theologian," unpub. Wi.A. thesis (Duke, 1942), p. 51.

${ }^{23}$ Colony to Province, pp. 53-67. It is true that Cotton wather, amone others, built on the foundation of the teachings of Hooker and his fellows sometiling very like Arminianism. See iniller, "Preparation for salvation," pp. 282-285. But it is not quite fair to hold Hooker responsible for this eighteenth-century Arninianism. 
theology had not been developed, he seems to have overlooked the fact that from Calvin's time onwards Reformed orthodoxy became more and more rigorous, more "scholastic," as we have seen. Thus to say that covenant theology mitigated the rigor of Calvinism is not quite correct; it mitigated the rigor of the Reformed scholastic theology, which was a good deal more strict than Calvin's teachings.

Another major effect which Miller attributes to covenant theology needs to be considered. According to Miller, ". - . by putting the relationship between God and man into contractual terms, they [covenant theologians] found themselves blessed with the corollary that the terms could be known in advance." When election "comes as a chance to take up a contract, they [men] must first of all know what is to be contracted."24 Thus with the covenant system God arranges "that we might know what to expect from God, and upon what termes." 25

[Al]. of this seerns to say that accordine to non-covenant Reformed theology the "terns" to which man must consent cannot be known before salvation. Miller offers us the opportunity to compare conversion according to covenant theolocy with converion according lo Calvin: crace comes as a flash of supernatural light, acming to calvin, but to the

${ }^{24}$ Colony to province, 55.

25 obadiah sedgwick, the Bowe]s of l'ender ivercy (London, $16(62), p .6$, quoted by hitien, Colony th trovince, p. 55. 
covenant theologians it is "a reinvigoration of the slumbering capacities of the soul." 26 But let us see whether this comparison is a fair presentation of Calvin's thought on the subject.

In the Institutes Calvin writes:

A simple external manifestation of the word ought to. be amply sufficient to produce faith, did not our blindness and perverseness prevent. But such is the proneness of our mind to vanity, that it can never adhere to the truth of God, and such its dulness, that it is always blind even in his light. Hence without the illumination of the spirit the word has no effect; and hence also it is obvious that faith is something higher than human understanding. Nor were it sufficlent for the mind to be illumined by the Spirit of God unless the heart also were strengthened and supported by his power. . . If there were only a single gift of the spirit, he who is the author and cause of faith could not without absurdity be said to be its effect; but... there is nothing strange in ascribing to faith the very gifts which faith prepares us for receiving. 27

Two points, here deserve attention. First, Calvin clearly assumes that those who are converted are exposed to the preaching of the gospel before grace works conversion. Faith is hilgher than understanding; but a degree of understanding--though of course it is not adequate for conversion -Calvin assumes will come before conversion. Second, conversion, to Calvin, is a reinvigoration of the various capacities of the soul, affecting the mind and the affections

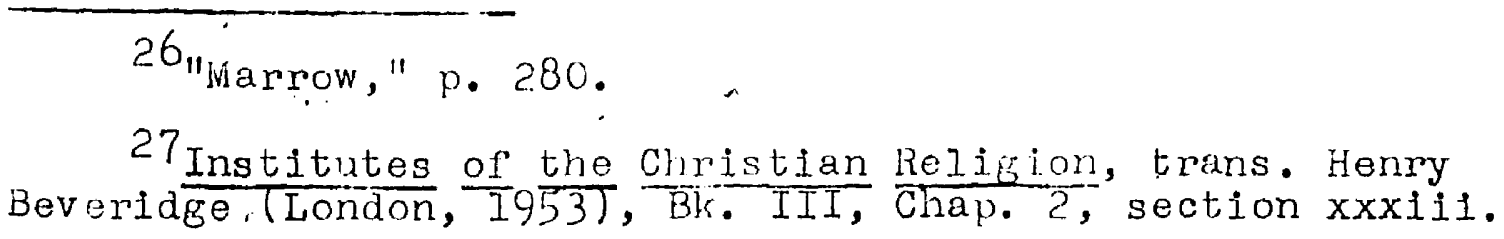


("the heart"). The gifts of the spirit are manifold.

Such an interpretation of the passage from calvin is supported by passages from his other writings. The gospel reforms us, declares Calvin, "by calling us to Jesus Christ, and by showing us how we must be regenerated by His Holy spirit." 28 "It is true, as the scripture saith, that we are saved by falth; for we know not that God is our Father, only by faith, and by laying hold of the promises contained in the gospel . . ."29 Nian must of course know what the, promises are before he can lay hold of them.

In conversion, "God begins... by exciting in our hearts a desfre, a love, and a study of righteousness, or (to s peak more correctly) by turning, training, and guiding our hearts unto righteousness." 30. For Calvin as for the covenant theologians, regeneration is a gradual pnocess. 31

Another difference exists between covenant theology and the older Reformed theoldgy, according to viller. Since the

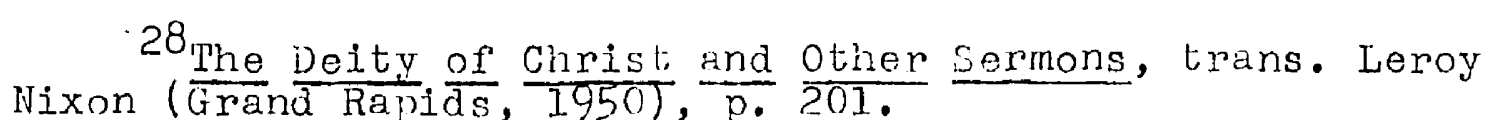
29 The Mystery of Godliness and Other Selected Sermons. (Grand Rapids, 1950), p. B7. Miller describes Calvin'sconcept of regeneration as "A forcible getrure of the surprised will." Though this may be, as willer states, "the blunt languace of Calvin," it is clearly an oversimplification of Calvin's concept. see itilier, Colony to rrovince, p. 56.

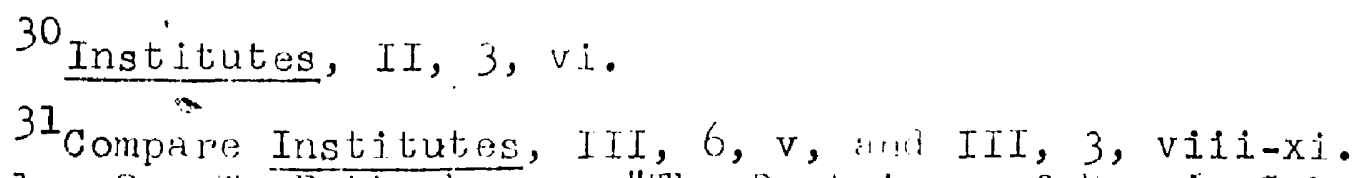
See also Roy $v$. Batteninouse, "The Doctines of man in Calvin and in Renaissance Platonis" "Journal of the History of

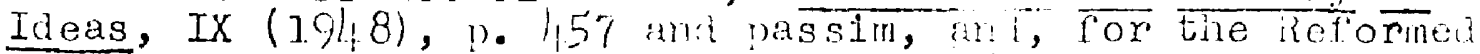
view in general, Hepre, jomatics, o. . 
covenant cannot be accepted unless sinners first learn what is proposed, the covenant 1dea had the effect of suggesting that there must be a time between depravity and conversion when the transaction of the covenant is proposed. This learning period, Miller contends, transformed heformed theology. Since convergion does not come like a flash or lightning, it can be prepared for. Wan can perform some parts of conversion, and so all men can be called to prepare for grace.' In this way, according to Miller, the covenant idea led to the concept of preparation for salvation. 32

But in his sermons Calvin likewise suggests that salvation can be prepared for, and, like the covenant theologians, he sets down the procedure, though in less detail. Since "we cannot draw near to what God shows and declares to us, unless we have first bowed down," 33 Calvin declares, "all men have to be humbled . . ." God will not provide for us unless "He sees that we are cast into the depths of all miseries." 34

- . when we s'hall be well persuaded that it is to those who are the most miserable that $\mathrm{He}$ addresses the salvation which He acquired, provided they recognize themselves as such, and they humble themselves, and they are entirely confounded, rendering thernselves blameworthy (as they are) before the judgment of God; that is how we shall have easy access ton be sharers of the righteousnass which is

32"Preparation for salvation," pp. 259, 277.

33 Deity of Christ, p. 4.1 .

$34^{4}$ Deity of Christ, p. 151 . 
offered to us, and by which we obtain grace and favor béfore God. 35 .

Here are clear directions as to what steps lead to converston.

M1ller further maintains that "The covenant made it possible to assume that while God elects whom He pleases, He is pleased to elect those who catch Him in His plighted word, and that it is up to fallen man to do so."36 Although the tones of Calvin's and Willer's language are very different, Miller's interpretation could be as readily applied to Calvin's teaching as to the teaching of the New inglanders. 37

Indeed, Calvin was not a covenant theologian, but the implications of covenant theology according to fililer--that

${ }^{35}$ Delty of Christ, pp. 151-152. Observe that Calvin "makes no reference here to predestination. Note also Calvin's statement in the Institutes: ". .. Christ... manifests himself to none but miserable and afficted sinners, groonine, labouring, burdened, hungry, and thirsty, pinine away with grtef and wretchedness, so if we would stand in Christ, we must aim at repentance...."--III, 3, xx. 36"Marrow," p. 274.

37 Accordine to willer, another aifference between the covenant theologians and Calvin is that for Calvin God was inscrutable, arbitrary, terrifyine, but according to the covenant theolonians, God through the covenant let himself. be "restricted and circumscribed"--"ivalron," pp. 262-263. It is true that; Calvin beliuved that "iij.s [God's]'majesty will. always be terrible and parful to us. If we hear mention made of lits everlasting olupose, ve cannot but be alfraid, as though the were peady to punge us into misery." However, this is not Cajvin's complete concent of God. He continues, "But when we know that all wore restetin in Jesum

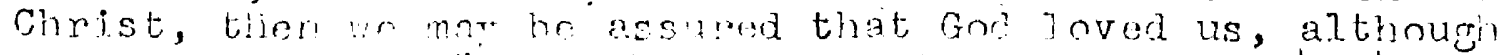

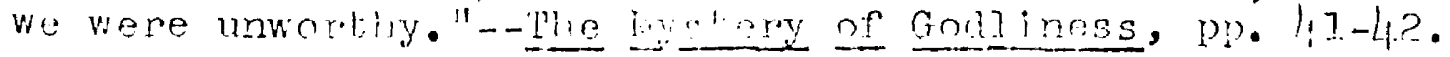


man can know ahead the terms of salvation, that man can prepare for salyation, that conversion is a process in which man's faculties are gradually transformed--all these are present in Calvin's teaching. They are not as fundamental to Galvin as to the covenant theologians because calvin usually assumed, as we have seen, that his hearers were already called saints.

The near-identity of the approach of Calvin and that of the covenant theologians can perhaps be demonstrated best by the following extended quotation from Calvin. In one of his sermons on the Ten Commandments Calvin declares that God Gave man the Commandments, saying,

$\therefore$ - all which I have done and doe, is onely for your profite, and for your welfare. I am then here - readie to couenant by articles with you, and to bind my selfe unto you on my part.

Calvin comments:

Seeing I say, that the liuing God doth debase him selfe so farre, I pray you shall not we be so unthankful, if we be not herewith beaten downe to humble our selues under him laying aside our pride and hautinesse. - . Nowe if this was to be done in the time of the lawe, then at this day much greater reason thereof: for the Lorde hath not onelie made a couernaunt for one time, as with the Iewes: but when he sent his onely sonne, then declared he him selfe to be our father und saujor much nore fullie than before he had done, and that anter so sweete, so gratious, and so ariable a manner, as nothing more: in such sort that he hath here as it were laid forth his bowelles of loue and compassion towards us. 
- . to frame our selues wholly unto him, renouncing euen our selues, and all our affections.

When we are inclined to forget to live in a godly fashion,

- Iet us haue in minde this couernaunt which the Lord hath made with us. 38

This passage should be adequate evidence that Calvin was not so different from the covenant theologians as lililer believes. The essential difference between the covenant theologians and Calvin is much more simple than what Miller has argued for. The sermons of covenant theologians are nearly all either attempts to persuade the uncalled, or exhortations to those who regard themselves as called to test their calling. 39 But Calvin's sermons, addressed to the alreadycalled, assure them of salvation and exhort them to be. grateful.

According to Miller, covenant theologians, after stating the conventional inability of man, "were at liberty to press upon their congregation an obligation to act, as though John Calvin had never 1 ived. 140 But as we have just seen, Calvin likewise pressed on his congregation the obl1gation to act, and in Calvin's semons, statements of inability are in fact, less common than in the sermons of

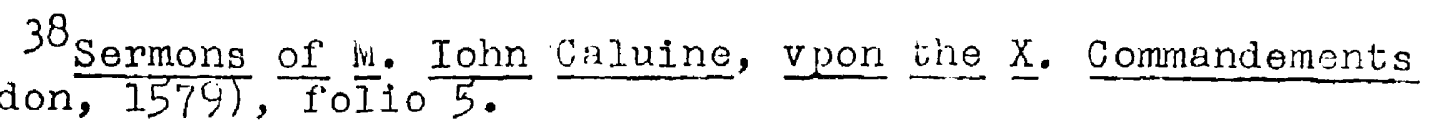
(London, 1579), foIio 5 .
39 Especially the sermons of the earlier "covenant" preachers.

40 "Preparation for salvation," p. ?2.
} 


\section{covenant theologians. Here is Calvin's customary approach:}

When we inquire about our salvation, we must not begin to say, Are we chosen? No, we can never climb so high; we shall be confounded a thousand times, and have our eyes dazzled; before we can come to God's counsel. What then shall we do? Let us hear what is sald in the-gospel: when God hath been so gracious, as to make us receive the promise offered, know we not that it is as much as if He had opened His whole heart to us, and had registered our election in our consciences ! 41

\section{Hooker's. Covenant Theology}

Having seen the difference which exists between Calvin's teachings and covenant theology, let us look at Hooker.'s

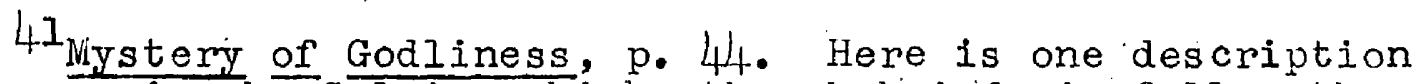
of conversion by Calvin, which, though brief, is fuller than - any other description that I have found in Caivin's sermons: ". . If an unbeliever come into the church and hear the doctrine of God he is reproved and judged. By this we understand that although the unbeliever may be.wrapped in darkness, and pleased with his own ignorance, yet when God so enlightens him that he seeth the misery and wickedness in which he hath lived, when he seeth his deplorable situation, while giving ear to the word of God, he perceiveth the hetvons open, as it were, and that man was not made for this life only, but to be exalted to a higher station. Thus unbelievers are convicted."--The Wiystery of Godliness, pp. 135-136. Compare with this passage the following incident told by cotton wather: "A profane person designing therein only an ungody diversinn and merriment, said unto his companions, Come, let us go hear what the bawling Hooker will say to us; and whereupon with an intention to make sport, unto Chelmsford lecture they came. The man had not been long in the church, before the quick and powerful word of God, in the mouth of his faithful Hooker, pierced the soul of him: he came out with an awaliened and a distressed soul, and by the further blessing of God upon wr. Hooker's ministry, he arrived unto a true conversion; for which cause he would not afterwards leave that blesser ininistiny, but went a thousand leagues to attend it, and enjoy 1t."--liagnalia Christi Americana (Hartford, 1820), I, 306. 
covenant theology and his techniques in conversion preaching. Two of Hooker's works deal'specifically with covenant theology, The Covenant of Grace and The Faithful Covenanter. But the first of these is concerned primarily with the covenant doctrine of baptism, and the latter, though helpful, is brief (only forty-two pages). It deals with the judgment of God against the English nation for not repaying God's goodness with thankfulness. Besides these we may pick out Hooker's covenant theology from some of his other works. Hooker refers to a number of covenants. In one place he speaks of the covenant between God and Christ which resulted in the atonement. This is the covenant of redemption. 42 Elsewhere he speaks of the covenant of works, by which Adam could have purchased life through obedience to God. According to the terms of this covenant, Adam was obliged to keep God's commandments out of his personal hollness, perfectly and exactly. 43 After this covenant had failed, another one was prepared, the covenant of grace, or, as Hooker gometimes calls it, the covenant of faith. The terms of this covenant are simple: "He that beleeveth shall live."14 For those who agree to the covenant of faith, therê is a further covenant: the covenant of walking before

42 The Saints Digritie, and Duty (Loncion, 1651), p. 30. Compare $\overline{\text { MII }} \overline{\text { Ier, Seventeent? }}$ Century, pp. 405-4.07.

43 The Fiathful Covenanter (London, 144), pp. 12-13. $44_{\text {Covenanter, }}$ p. 10. 
or with God. Man agrees to perform God's commandments in proportion to the grace he receives, as an indication of his thankfulness. Hooker also calls this the covenant of God's law or the covenant of evangelical obedience. 45 Th1s covenarit is unlike the covenant of works in that it cannot be kept by man's own power and is unlike the covenant'of works and the covenant of grace in that it is not rewarded, when kept, by life and salvation, since those within it are already saved by fajth. 46

As a result of the key covenant, the covenant of grace, God appears to have limited His power, for He promises to save those who have raith. Hooker, like otiner New England Puritan theologians, 47 spoke of God as actually beine bound by the covenant arrangement. But this description is only Hooker's way of describing how the redemptive process appears to man, who cannot of course know who is saved. God indeed appears to be bound ton save those who believe, but Hooker declares that he who believes and is saved by falth, believes only because Gnd has civen faith to him as one of the eject. It is indeed true-from man's point of view-that "He alone, of his own unfettéed will, proposed that

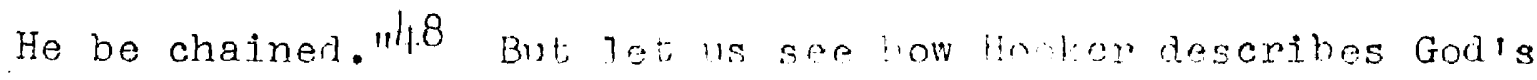

\footnotetext{
$1,5$ Covenanter, pp. $10-7], 13$. 1,6 Covenanter, rpe. $13-1 \%$. 1.7 See liili er, Seventeonth Contury, $: 1 \cdot 379-380$. 48 Milier, Seventeentin Century, n. $3 \%$.
} 
self-limiting arrangement. He says:

God is bound to none further then he will bind himself; and he binds himself in no wise to the creature, but by his promise, and that he wll never deny, who cannot deny himself. "Now in the Gospel only this promise and ingagement of God is revealed, he hath promised to work the condition [that is, to supply falth], and then tied himself in his truth to. do good to those, whom he wil so fit for his mercy. And now the soul upon this notice grows in upon God, here is a handle, as it were, for faith to lay hold on . . . 49

Here Hooker seems to regard the covenant arrangement as nothing more than a subjective description of the redemptive process: a useful description because such an arrangement looks attractive and is thus useful as persuasion--and per-. suasion accompanies (according to Hooker) God's saving grace. 50 For Hooker, then, God's covenant is with the elect --with those "whom he wil. . . fit for his mercy." such only is. God's promise.

The Father.. I laies al his excellencies, and sufficlency to pawn, that he wil see the salvation of his shal not miscarry. As he is said to swear by himself, he cals his God-head, as a Witness to see. done what he saies. So, I may say, he doth by his Promises, lay his infinite sufficiency to pledg... God sales, require what may be needful, or helpful at my hand, I wil answer it.5I

All things necessary for salvation shall be supplied to

\footnotetext{
${ }^{49}$ A Gomment Upon Christ's last prayer (London, 1656), p. 7 .

${ }^{50}$ Seo above, Chapter III.

$51_{\text {Christ's }}$ last Prayer, p. 390 .
} 
God's elect.52 Whlle God's covenants rely on the condition of faith and thus are never absolutes, grace effects the condition. 53 By this arrangement predestination is never dented--is indeed affimed--yet by making redemption depend on the condition of falth, God can present his irresistible grace in the form of persuasion.

One of the most important aspects of the covenant Idea for Hooker is its relationship to his teachings on baptism and the relationship of elect parents to their children. According to Hooker, God may use the elect as means of salvation to their children, 54 because

Beleeving parents when they enter into a visible covenant to walk in Gods wayes, they enter not for thremselves alone, but for all that come of them; and God does ingage himselfe by their meanes to
worke grace in their hearts as he sees fit. . 55

The children receive grace automatically when their parents are called saints, though such grace, "federall grace," is

52 Compare Calvin's declaration, "Yea (and as I sald before), Jesus Christ hath taken charge of our souls, and will not suffer us to be taken out of His hands."-The llystery of Godliness, p. 88 .

53 The Application of Redemption: Whe first eight Books (London, 1656 ), pp. $30-38$. and pasime

54 The Covenant of Grace Opened (London, 16149), p. 56

55 Covenant, 1, 35. The visible covenarit to which Hooker refers here is the church covenant; submitting one's self to such an agreement was one of tire requirements which an adult must fulfill in order to be tabtized. Others wer. to be decided upon by God's ministris. See liooker, Covenant, p. 19, and, for backround, iniller, Seventeenth Century, pp. $432-1,62$. 
not saving grace and may be lost. 56

The child of a saint is

made partaker of the covenant with the father, and by the father God hath promised, that [the father's partaking of the covenant] should be a means, not that the father conveyes frace to the childe (that Iflar dream) but he [God] uses the father as a'means, and will communigate himself to the childe, as he sees fit... . 57

Because God is likely to use the parents, as a means of grace, it is likely, according to Hooker, that children of the elect also belong to the elect. Such children may, therefore be baptized, since baptism and the other sacrament, the Lord's Supper, are seals of election: ". . the Seales doe not give the first grace; but do presuppose that such as doe recelve them, are within the covenant of Grace. "58\% Although the sacraments are not causes of salvation, 59 they do have a valuable function: they serve to strengthen fajth, in Hooker's view, by presenting Christ visibly to the soul; they show Christ's merit and obedience

56 Covenant, pr. $35,41,43$.

57 Covenant, pp. $20-21$.

58 Covenant, mp. 16-1.\%. It should be observed that elect children gre referren to here as beinf within the covenant of grace, though they are as yet uncalled. Such a situation makes clear this cor liooker iredestination underlies the covopart arrange int.

59 The Soules Humiliation (Amsterdul! 1638), p. 38. 00 rament saith, grace is not in mee. . . 
and make men's hearts love Him. 60

Covenant Theology and the Sermon as a Means of Grace

Hooker, then, was thoroughly familiar with covenant theology; his teaching on baptism was such that in this aspect of his thought he may be readily labelled a covenant theologian. 61 a much more important question must now be considered. It has been argued that Hooker and others were able to demand of their congregations that they take steps which were actually inconsistent with the Reformed doctrine of predestination. lililer puts it in this fashion:

Some of them [the covenant theologians], notably Hooker and Shepard.. . even argued that before any faith was generated, before God gave the enabling grace, merely from the incentives of the means, a man could at least "prepare" himself for receiving the faith, though out of this argument were to grow conclusions still further removed from the pure doctrine of Calvinism. The final outcome in all. New England preaching of the covenant theory was a shamelessly pragmatic injunction. It permitted the ministers to inform their congregations that if any of them could fulfill the Covenant, they were elected. 52

The difficulty with this analysis is that it overlooks

\footnotetext{
60 An vixosition of the princiules of Religion (London,

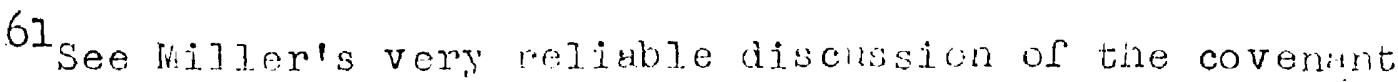
view of the sacranents in "ine puritan iroory of the sacrimerits."

${ }^{62}$ Seventeenth Centum, p. 395; iblics mine.
} 
the Puritan theory of preaching, according to which sermons are sacramental in nature. In his chapter "The lieans of Conversion"163 Milier provides an excellert discussion of the Puritian concept of preaching, although it seems unfortunate that the relationship of Puritan theory to Calvin's theory is not discussed. But in his account of covenant theology he neglects to take into account thrt purtan preaching theory, considered against the backcround of Reformed "Hich Calvinist" theology, provides an adequate explanation for. what he calls the preachers' "shamelessly pragmatic injunction."

Briefly, the thesis to be developed here is that Hooker and others of his time were fully convinced that natural man could not be called unon to do the work of redemption, as many earljer puritan preachers had prescribed. In the early" seventeenth-century intel. Iectual climate, the orthodoxy of Dort and westminster would have labelled the earlier preachine practice, with its s]ifht references to predestination and spiritual jnability, as Arminianisin. But the puritan theory was that, since God's irresistible crace is always matched with the preacher's persuasion, the sormon is normally the means of grace. 'his theom movided a method by which belief in the inability of ratiuml man could be maintained by the preacher whito he exhortinl sinners to be saved.

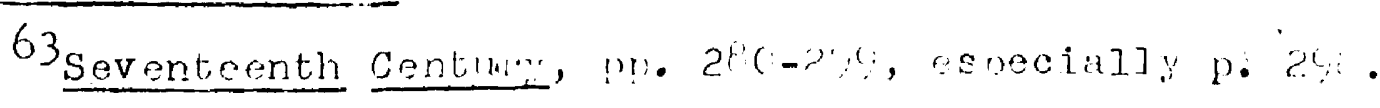


- A passage from Hooker's writings may help us to understand the role of "the means of grace."

Chrlst giveth us right to come out from under all iniquitie, but Christ requireth that we our selves should bring our selves from under iniquitie. It is true indeed, we cannot doe it, but by christ, it is the grace of Christ, the power of Christ, the spirit of Christ that doth help us to get ourselves from under infquitie; yet notwithstanding we must 1 abour to get ourselves from under it, and Christ will help us. 84

This perhaps confusing passage deserves explication. According to the interpretation being presented here, it may be explained in the rollowing fashion. By declaring that natural man is unable to do saving works unalded but requires God's grace, Hooker completely avoids Arminian doctrine. But as a predestinarian he can ask man to labor to get from under infquity, assuring him of Christ's help. If he does so, because only the elect will so labor, and the elect (of course) labor with Christ's help. Or, as Hooker puts it elsewhere, ". . $\because$ a man must will mercy before hee can have mercy, and whosoever doth will it shall have it. . . "65 For Milier, this is a departure from the essential and pure doctrine of Calvinism; it is a shamelessly pragmatic injunction. But what would he fropose as the truly Calvinistic alternative to llooker's teaching? Calvindoes not or course

\footnotetext{
61. Saints Dignitie, $\mathrm{r} \cdot 38$. 65 The Unbeleevers Plopiding for Cinrist (London, 1638), Pt. I, p. 27 .
} 
teach that man will receive what he does not want. He follows Augustine and argues that ". . the Lord prevents the unwilling in order to make him willing, and follows after the willing that he may not will in vain. . . "66 Heppe's summary of the Reformed position on this aspect of conversion elucidates Hooker's orthodoxy on this point.

- - thé H. Spirit [sic] so works upon man as to esteem him a personal creature and so does not regard him as a clod or a stone, but acts so that enlightened by the Word and impelled by grace man recelves in conversion the will to convert to God and so his conversion takes the form of spontaneity [it alics mine]. Yet since in conversion every sort of co-operation of man's will with the H. Spirit is completely excluded, the activity therein exercised by the H. spirit is no merely natural, merely moral or mediate activity (no mere suasio per verbum), but at the same time and pre-eminentiy an immediate, Wunarnatilnol ano in whinh tho H Snirit avails itWord, works essentialiy and irresigtibly way comthe thought, will and Iife of man. 6 ? Word, works essentially and irresigtibly . . upon the thought, will and life of man. 67

It is to be noted that according to this view, the redemptive process includes man's willing to be converted, and that although the process is supernatural, it also involves suasio per verbum. As we have seen, in the thought of botin the Continental Reformed churches and Puritanism, God's irresistible grace is accompanied by persulsion, for persuasion is the outward accompaniment of crace for the elect, serving the purpose of "rationalizing" irresistihle grace.

$$
\begin{aligned}
& { }^{66} \text { Institutes, II, 3, vii. } \\
& 67 \text { Dogmatics, n. 52]. }
\end{aligned}
$$


From this point of view let us now consider additional samples of what may appear to be Hooker's Arminianism. In The Unbeleevers Proparing for Christ Hooker declares, ". . what a thing is this then, when neither vinister can perswade thee, nor Angels exhort thee, nor Christ himselfe intreat thee to take mercy . . . "68 Is Hooker saying that persuasion ought to be enough? Is it that Christ's entreating itself can be resisted? According to the Remonstrants (Arminians) at Dort,

The operation of grace in the beginning of conversion is indifferent, and might be resisted, so that man can be converted by it or not: and the conversion does not necessarily follow unless man by his free congent decides for it, and wants to be converted. 09

Hooker's position would seem to be quite proper Arminian doctrine. In the same work Hooker writes that on Judgment Day God will laugh and say, ". " how often have I sent unto you, and called upon you, and you would not heare nor regard mee. Behold men and Angels, this is the man, this is hee that contemned my word, and slighted the meanes of salvation . . ."70 Is God laughing at reprobates, or at those who chose to resist His apparentiy resistible grace? This question and the two ubove can be reduced to two possibilities: (I) Hooker is being inconsistent with the very

$68_{\text {Pt. I, p. } 125 .}$

69 Quoted by Bernhard citron, New Birth (Ninburgh, 1951), p. 121.

70 Unbeleevers Preparing, Pt. I, o. 3.83. 
strict predestinarianism which is to be found throughout his writings, for he realizes that one cannot preach prodestination and expect to convert one's hearers; 71 or (2) Hooker is using these declarations as attempts at persuasive logic, knowing that from man's point of $v i$ ew it appears that one can accept or reject God's grace. The second view is more consistent with the outlines of Hooker's thought, although accepting either alternative may lower our estimate of Hooker as a man. In dealing with certain other passages we have had to take into account Hooker's attempt to see the redemptive process from the human point of view; apparently. such is the situation here.

of course it may be argued that one of the standard doctrines of Reformed thought is presented in these two quotations from Hooker, especially the latter; this doctrine teaches that although their calling is ineffective; tile reprobate may be "truly" called-by the outward word though not by inner grace. 72 Such an explanation makes Hooker seem more orthodox, but it is inrortant to see tist Hooker's purpose in these passages is not merely instruction in the doctrines of religion, but is rather persuasion. Accorling to

71 F. H. Hostar arpuos that the strict predestinarian meaching of the purjtans of tho efrotor seventeenth century was later abandonod becauso of tilis protical difficulty. Seo his Genetic Migtom, ?: 26-3?.

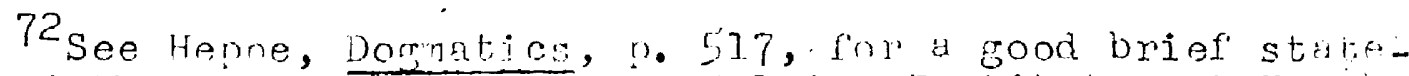
ment or the doctrine. Sen ano Calvin, Institules III, il,
viil. 
$<$

the standard organization of Puritan sermons, Hooker's purpose here is "exhortation."

Hooker used even the doctrine of reprobation as a device for exhorting men to seek salvation. If a man has lived for a long time under an effectjve minister and is not "prepared" for salvation, it seems Ilkely, suggests Hooker, that God does not want him to be propared. 73 Although illier regards such a statement as "apparently contradictory to a ifteral interpretation of the doctrine of natural inability," 74 there is a practical basis for Hookerig charge: that it may persuade men to use the means at hand.

The concept of "the means of salvation" made" it possible for Hooker to remain a predestinarian and yet offer his hearers assurance of salvation. We should "bestir our souls in the use of all means to entertain a Savior. . and we shal not mis of our expectation." 75 Here Hooker offers assurance of election as a reward for using the means of salvation since only the elect will choose to use the means and use them properly. For "without means thou hast no reason to think that God wil work.: . "76 If men "have prayers and sermons, and exhortations, and admonitions, and

73rhe Soules Implantation (London, 1637), pp. 75-76; also The Application of Redemption: Ihe Ninth and penth Books TLondon, 1657), p. ?ठ8.

74 Seventeenth Century, p. 297.

75 Application, Bks. I-VIII, n. 149. 76 Application, Bks. IX-X, p. 1436 . 
comforts," then they have "all things that are available to bring a man to Iffe and hapiness," 77 for the means, "so far as he [God] is Pleased to appoint and use them," are instrumental causes of the application to sinners of redemption. 78 God does not use miraculous means now as once he did; 79 now God's means of salvation is "the ministry of the Gospel." 80 The doctrine of means furnishod Hooker, as Miller wisely says, with "a common meeting place for irresistible grace and for reason. It made the grace compatible with nature without doing violence to nature or reducing grace to a natural influence." 81

A contral problem in studies of puritun thought is the role of preparation for salvation. As we have seen, iviller has argued that covenant theologians crlled for man to use "his natural ability to prepare ror grace. The assertion." that the Puritan doctrine of preparation was not quite orthodox is not a new one. The late seventeenth-century Reformed theologian Mitsius criticized gently the teachings of Perking, Ames, and the British divines at Dort for their view of preparation, which he found confusing and somewhat unorthodox. These theologians, he says, teach that God

77 Sgints Dignitie, pp. 213-21\%.

78 Application, Bks. I-VIII, p. 111.

79 Unbeleevers Preparing, it. I, I. 160.

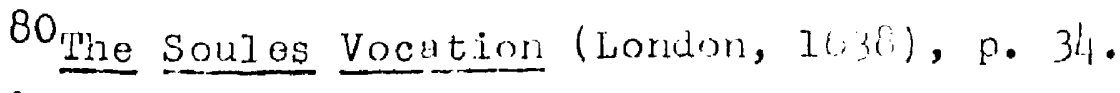

$81_{\text {Miller, Seventeontil Century, }} 1.43$. 
takes preliminary steps in the conversion process in order to prepare the soul for conversion itself. These steps, such as a serious consideration of one's sins and despairing of one's salvation on the basis of personal merit, are, according to Witsius, the results of conversion, not preparation for it.82 An Englishmen of the seventeenth century, William Pemble, denounced those who teach that preparation apart from grace is possible. 83 Traces of voluntarism have been found in Perkins's teaching on preparation by Ralph. Bronkema, who also cites examples from the Puritans Owen and sibbes. 84

The heterodox position is perhaps best stated by John Preston. According to Preston, although a man cannot save inimself,

- yet withall, I say, he hath power to doe those things, upon neglect of which, God denies him ability to beleeve and repent: So that, it is true, though a man cannot beleeve and repent, and nevertheless for this is condemned; yet witha].l take this with you, there be many precedent acts, which a man hath in his liberty to doe, or not to doe, by which he tyes God, and deserves this Iustly, that cod should leave him to ilimselfe, and deny him ability of beleeving and repentirig. 5

Witgius, The Economy oi the Coverants (Edinburgh, 1803; first edition, 1685), I, $366-368$.

${ }^{8} 3_{\text {See }}$ Vindiciae Gratiae," In Works (Oxford, 1659), pp. 78-84. liller sumarizes pemblets position in colony to Province, p. $5 \%$

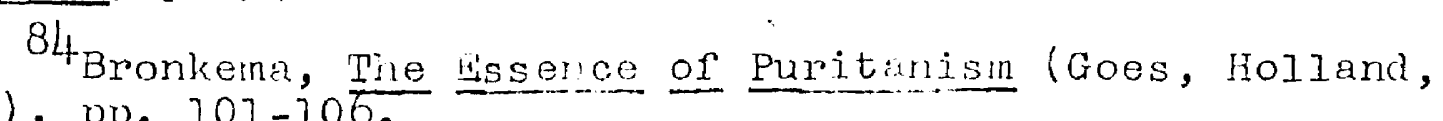
1929), pp. 1.01-106.

p. 225 .

85 Preston, The Saints Lualification (London, 1634 ), 
a

Man "ties God" by failing to prepare.

John Norton, in The Orthodox Evañ்elist, is likewise unorthodox, but in a different manner. He describes preparatory work as "the effect of common grace: as saving work is the effect of free special grace." "Preparatory Work, taken in 1.s full Extent, is the whole frame of inherent Qualifications; coming between the rest of the soul, in the state of Nature, and Vocation; whereby the Soul is put in a next disposition, or lvilnisterial Capacity of believing immediateIy, $\underline{i} . \underline{e}$, Of immediate receiving of the Lord Jesus Christ." 86 For Norton this preparatory work "hath no necessary connexion with salvation." 87

The position of Norton and Preston is the New England Puritan doctrine which Miller has discusied.

Giles Firmin, a Puritan of the later seventeenth century, was very critical of Hooker's teaching on preparation. He reports:

When Wr. Hooker preached those Sermons about the Souls preparation for Christ, and Humiliation, my Father-in-law, Mr. Nath. Ward, told him, Mr. Hooker, you make as good Christians before men are in Christ, as ever they are after; and wished, would I were but as good a Christian now, as you make men while tiey are but preparing ror christ. 88

86 orthodox Evangelist (London, 1654), pp. 139-141.

87 Evangelist, pp. 100-101. According to Niliiam Perkins, man has certain knowledge of God naturally, and this should "be preserued with good bringing vp, with diligent instruction, and with good company. . . "--A Treatise tending unto a declaration . - (Lonion, 1589), p. 3. For John Cotton's position on preparation, see chapter VI below.

88 Firmin, the Real Christian (Lonion, 1670), p.' 19. 
According to Firmin, Hooker demanded more than God requires. Against this rather detailed background, let us look at one of Hooker's works to which Firmin refers, The Soules Preparation for Christ (London, 1632). Hooker held that the parts of preparation for Christ are two: contrition and humiliation. 89 The Soules preparation is subtitled A Treatise of Contrition, Wherein is discovered How God Breaks the Heart and wounds the Soule, in the Conversion of a Sinner to Himselfe. Thus witholxt going beyond the title page we leam that contrition is God's work, not man's. Throughout the work itself appear such phrases as "how the Lord workes this somrow" (page 125), and ". . this sorrow in preparation is rather a sorrow wrought upon me, then any worke comming from any spiritual ability in my selfy lsic]" (pages 155-156).

Unlike Preston and Nortion, Hooker majntains that preparation "is a 'savinc worke, and a worke of Gods spirit . . ." (page 157). Though Norton argues that preparation has no nocessary connection with salvation, Hooker argues that "the work of contrition of heart is wrought in every one in tilis worke of preparation, before he is, or can be planted into Christ . ." (page 158). For Norton, preparation puts the soul into an intermediate state betweor depravity and salvation. But according to linoker, "when bite heart is fitited and prepared, the Lord chust comes imaliately into it" (page 155). Preparation ines not merel. mut the soul into : ${ }^{89}$ Soe soules Imnlantiation, m. 3-1. 
condition such that Christ may enter 1t, but puts it into a condition such that Christ does enter it. Therefore if a man has been prepared and dię, his salvation is assured (page 155).

Contrition'is, then, God's work. God's means of bringing men to contrition-to a true sight of sin and hatred of it--is "to prick their hearts." But God's methods differ. He may choose to give a man a violent blow, such as st. Paul received on the Damascus road. But the more customary method is through the agency of "God's ministers, especially in sermons (pages 125-131). If this is the situation, we may exriect that Hooker's aim in this sermon will be to prick men's hearts, to bring them to a recognition of their sinful state and to a hatred of it. If he succeeds, it is of course only because God is working in men's hearts as he speaks.

Perhaps the most userul method for presenting fiooker's technique of making men contrite is to examine the main points of The Soujes Preparation, now that we understand how the work is to be considered. As usual, Hooker's method here is to present a series of doctrines, each of which consists of a definition or a proposition. If the doctrine is a definition, each part is taken up and considered in detail, word by word, phrase by phrase. If it is a proposition, it is usually derended immediately. One of Hooker's greatest assets is his ability to statio the case against his proposition and answer it just at the time when the objection 
Is most likely to dccur to the reader. After the doctrine has been defended or defined, the reasons why there should be such a doctrine are presented. Then comes the heart of the work, the uses of the doctrine. Hooker's works were always designed to be practical. After the uses comes another doctrine, often one which is prepared for by the preceding doctrine. In this presentation, it will be necessary to omit many of Hooker's lesser points.

As the title statés, The Soules Preparation is a treatise of contrition--its nature, purpose, and method. The text used is Acts 11. 37: "Now when they heard this, they were pricked in their hearts, and said to Peter and the other Apostles, Men and Bretheren, what shall we do to be saved?" Hooker begins his discourse with a definition of contrition as the hatred of sin after it has been truly percelved, so that the result is a separation from it. Thes definition is important, but falthough Hooker is careful to discuss it fully at this step, the most significant parts of it--"the true sight of sin" and the resultant hatred for and separation from sin-form the substance of the seimon proper. The sermon thus can be regarded as an explication of the meaning which Hooker assigns to "contrition."

The first doctrine does not seen to be of special significance, and indeed Hokep does not enphasize it, but uses it merely to lead up to the second doctrine. The first is that it is possible for the most stubborn sinner on eartin lio get a "broken heart" (that is, to achieve contrition), sinco 
God is all-sufficlent and can pardon all sins, the sin against the Holy Ghost excepted. This doctrine, which Hooker bases on scripture, is presented for two purposes. First, Hooker hopes by it to universalize his message, for this doctrine checks discouragement. Second, he uses it to caution his listeners that, while it is possible for even the worst of sinners to be saved (as far as he can tell none of his hearers is excluded) much mercy is needed. clearly. such a discussion is a necessary and naliural preitiminary, since Hooker must persuade all of his uncalled hearers that his message is intended for them, but that the means of remedying their condition is not ensy.

The second doctrine is a crucial. one-there inust be a "true sight of sin" before the soul can be broken. Sin, according to Hooker, is an opposing of God, though it is not often recognized as such by tho sinner, either because he has regard for the nleasures or profits wich he seems to derive from sin or because sinful man consillers God to have endless patience, and so thinks that he can always repent later. But, says hoker, sin deprives man of his greatest good, unity with God, and tiris is to be feared more tian Hell. Itselr, especially sirce it is s cause of Hell and also iss a cause of pain to Goil, who is $\Lambda 17$ Goodness. inian must see sin clearly, recorniaing it as sill and seeing its conse-

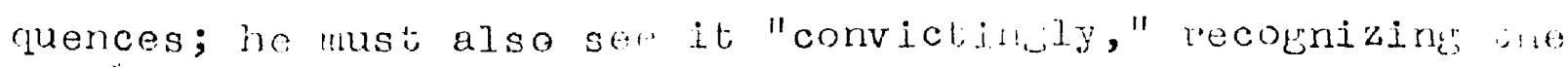
evils of particular sins. As we read on, we my flind omsolvas wnmerint if 
Hooker is not assuming a great deal when he says that contrition is necessary for salvation. Because of the numerous issues involved, Hooker on this occasion and elsewhere asked his audience to accept certain doctrines at the beginning of a discussion which he is to defend later.

The method of achieving a true sight of sin is to ask God for knowledge, and to study God and His Law, accepting His truth without objection.

In the summary form presented here, Hooker's discussion may sound objective and impersonal, but in the work Hooker constantly intersperses such addresses to uncalled sinners as the following:

I pray you in cold blood consider this; and say thus, Good Lord! What a sinful wretch am I? that a poore damned wretch of the earth should stand in defiance against the God of hosts, and that I shouldsubmit my selfe to the devill, and oppose the Lord of hosts? (page 18)

Man, Hooker realizes, develops many devices, to escape from a true sight of sin. It is in this discussion, nore than elsewhere, that Hooker shows why the means of salvation which he prescribes is tine only real way. He flrst considers the common excuse that sin is not daneerous. wany, ire says, contend that sin is common (but thore is much room in Hell) and natural. Some siy:

- - there ís also a naturalnesse in a sinful course. - it is my natures and my infirmity, and I arn of a cholerick disposition, I shal sometimes sweare, when I ail angry; and I cunnot but bo drunke sometimes, when ] 7 ight into sood company ... . 
Nay, dost thou say it is thy nature to sin? Then I s ay the greater is thy wickednesse, if it be thy nature so to doe: We hate not a man because he drinks poyson, but we hate a Toad because it is of a poysonous nature; therefore rather mourne the more for thy sinnes, because it is thy cursed nature so to doe. (page 4.0 )

Others complain that their sins are the result of impulsive thought, but, Hooker answers, thought is the essence of sin. Commonly our sins seem so pleasant tikat we stay" with them even though we recognize them as bad. But this, says Hooker, denies God.

Another device which man uses to escape from a true sight of $\mathrm{sin}$ is to trust to luck that he will not be punished. Perhaps he assumes that God does not heed his little sins, but God by His nature'sees all. Or perhaps a man admits that God observes his sins, but procrastinates, saying that he will revent later. Hooker reninds us that any time but now may be too late, for, al though some say that Christ will be merciful ánd save tirem, God's mercy is not always gvallable, and if it is offered and not accepted now, it will not be offered later. (This is a recurring idea in Hooker's works.) The sinner may say that if he is to be damned, then he will just; have to acceot his fate. But, Hooker protestis, we cannot bear our consciences now, and this is merely a fortuste of hell. "ookel reninds his hearers that Jesus Himself could not bear the sufferine of the cross. Hooker presuribily expects that all of these "sinifts" are to be found wome his herp rs. 
Next Hooker provides his listeners with three motives for contrition. First, contrition is the only way to reach Heaven. Second, it is not difficult to achieve contrition If one will only start now. Thira, great joys wifl be the reward of the contrite; being contrite is the "most comfortable course in the world" (page 59).

The next doctrine is that a special applicution of particular sins is a chief means to bring people to a sight of their sins and to a true sorrow for them. Hooker argues that a minister can best bring sinners to repentance by telling them speclfically wherein they sin. Winisters feel discouraged about using this. technique because the truth hurts. But ". . we commit sin, because we see it not, and therefore sorrow not for it" (page 3i).

The next doctrine is of considerably greater importance. A serious meditation of our sins in the light of the word of God is a special means to break our hearts for oux sins. Hooker defines meditation as a settled exercise of the mind for a probing inquiry into a truth, and for the arfecting of the heapt therewith. It brings truth hoine by taking much time and full attention for the matter. The grounds upon which meditation is based"are God's mercy and justice, and a considerition of the seriousness of one's sins and the punishment they deserve. The method of meditation is to think of these prounds contimously, seeking pardon without stubbornnes, wich is niten, accordine to Hooker, the obstacle thit, kens men tron salvation. It in 
based on a belief that man does not need Christ. This is really either an unwilingness to be ruled by Christ or a belief that Christ will not provide mercy for sinners until they improve themselves. 90

Further in the method of meditation, and most important, is the idea that the heart must be pricked. Pricking means feeling grief and sorrow for sin and a desire to be severed from it, and a dependence on God for help. This concept of pricking seems, from the point of view of logic, to be a flaw in Hooker's argument, since he contends that meditation is a process that one $\operatorname{can} \operatorname{choos} \theta$ and execute, and at the same time he holds that the pricking comes from God. But we should remember that the preacher's exhortation was regarded as coming from God, as were also the willingness to choose meditation and even tire ability to meditate. Hooker does not suggest here that some may be predestined to eternal damnation, 91 but at least implies that all of his hearers have a chance to be saved. While this may seem contrary to what he should have held as an orthodox predestinarian, it is the only approach psychologically feasible. Hooker next discusses God's means of pricking men's

90 But in "The Preparation of the lieart" In Soules Implantation, Hooker argues that man musi eliminate his "sinf'ul lusts before he can be saved. Hooker's position as found in Preparation is also to be found in Soules Vocation (London, 1636), r. 5\%.2.

91 Except those who have cormitten bile sin against the Holy Giost a sin witin wi.j Hooker j.s not here concernea. 
hearts. The first means mentioned is a violent blow, such as that which God gave st. Paul on the Damascus road. We may expect from this introduction that Hooker is going to show how God may intervene directly in the process of conversion. But the violent blows which Hooker suggests, are. supplied through the agency of preachers, especially in their sermons. Other means discussed are reading, hearing, and conferring concerning God's Law, and realizing the dangers of Hell.

Hooker next discusses the sequence of events in contrition, a description which some of his hearers doubtless felt was a good example of Hooker's deep understanding of the processes of the mind. Perhaps it is more useful to note that his description demonstrates an understanding of the powers of suggestion. Early in the process of conversion, according to Hooker, the individual begins to have a bad conscience and then to recoenize his sins clearly. With this recognition comes sorrow, becaluse the sinner is unwill.ing to part from in sins yet realizes that they delile him, separate him from God, and make him likble to the punisinments of Hell. As the process continues, the sinner begins to feel a great sorrow for even his litile sins, and romotimes,

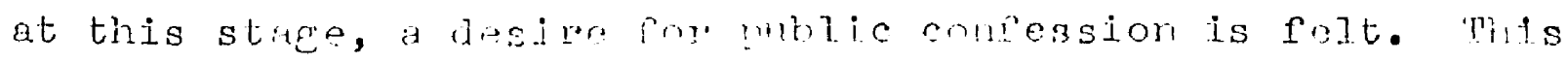
sorrow, be it noted, is histinct froll bie earlier sorrow, which might he crlled tir: sorrow of bue dilemma, and comes

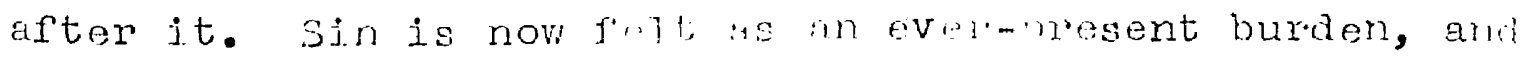
the createst desire of the sinnor is to remove it. This 
"sound sorrow" is altogether necessary for conversion and salvation, according to Hooker, because it is the only means of true preparation for Christ. It is the only means because man must cast off his sing before he is acceptable to God, and yet the soul will not depart from its sins until it is weary with them. When the soul has $\operatorname{com} \theta$ to hate its sins, when it has reached a "sound saving sorrow, it is saved, although the process of conversion is not yet com-. plete.

Hooker stresses and re-stresses that man must know what he is being saved from--his sinful state--before he can be saved: ". - all men niust be thus disposed before they can be saved; and if thus fitted and disposed; they shall be certainely savod; It is not enough for a man to be in a miserable statj and damnable condition, but he must also see it . ." (page 159). Witingut a true sight of sin,". . you . - keep your sins as sugar under your tongues, and will be loose, and malitious and covetous still" (page 230). God's method of conversion is always the same, says Hooker; it is always through contrition. But there are several manners which He uses, denending on the condition of the sinner. If a man is an opmoser of God, he will have his heart utterly broken. If a man has continued long in sin, he must see all of his sins fully. If He plans to do a great worl: by a man, the Lord acts violontly. But

- - if tire soule be .". truined up anone godiy parents, and live under a sould-saving iilinistiry, linit 
saith, you cannot goe to heaven by a civill course, $\checkmark$ and you cannot have any dispensation for your prophanation of the Sabbath; I say, if a man Iive under such a Ministry, and keepe good company the Lord may reforme this man, and cut him off from his corruptions kindly, and breake his heart secretly in the apprehension of his sinnes, and yet the world never see 1t. (page 168)

Next Hooker turns to the "fruit" of the sorrow of which he had been speaking, basing his remarks on the question asked Peter and the other apostles after Peter's sermon, "Men and bretheren, what shall we doe?" Hooker believes that the questioners see their horrible condition, are ignorant as to what course to take, and yet hope that somehow something can be done. (Presumably Hooker hoped that some of his hearers were, at this point in his sermon, in the same condition.) on this basis Hooker builds the doctrine that there is a secret hope of mercy wherewith God strengthens those who are truly broken hearted for their sins. (of course he is also arguing that men at this stage have such a hope so that his hearers will as a result be hopeful.) Since an individual sees that there i's hope for him, he is able to make a true confession. A true confession can come only from a truly contrite soul wino vesolves inwardly, as he confesses, that he wili sin no more, but who at the same time has no confidence jn himself and bhe pefore leans on God for help. only those can ask for heln who believe that there is stijl. hope of salvition. A man will not confess un].ess he feols some assulance tiat he will be pardoned. A Iate part of Fooker's work is a jungthy aiscussion of 
the role of the minister in confession, a discussion which today lacks the interest of the earlier parts of the work. Although a minister cannot absolve a person of his sins, confession to a minister is very important, in Hooker's view. In fact, it seems clear that Hooker regarded preaching and the adviging of souls in confession as the two most important duties of a clergyman. Hooker regards a minister as a physician of souls. He should be skillful and experienced, merciful yet falthful to ford he must be no respecter of persons and should regard what he hears as entirely private.

Hooker concludes with another doctrine: the soul which is truly pierced has a restless hatred of sin. This hatred has two parts: a desire to have sins discovered so that they may be killed, and a hatred of sin in others and of anything which has to do with sin. Hooker's attitude here does not seem to be in any sense that of the self-righteous puritan; it is rather that he is not a man who wijl tolerate what he considers evil. To Hooker this hatregd is a sign of electjon, fon, he argues, if one hates sin, he may be sure that his heart is broken and he wlII, as a result, have saving grace. This 1dea brings Honker to a final eloquent observation:

If bijs hatred of sinre be a liwe evidence of broken heartedne'sse, what wi.l. become of a world of prophare persons, that are carried on with the pursuit of sinne from whil thoy will not be plucked; the drunkard will. have his culs, and the adulterer.

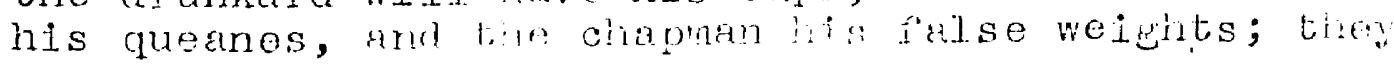


are so farre from this dislike of sinnes, that they hate everything save sin . . and say . . what shall we doe? - . What shall we doe that we may not be checked and reproved? get you down to hell, and there you shall have elbow room enough; the re you may be as wicked and prophane as you will. ( pages 241-24.2)

Let us consider now the method used by Hooker in this work. First, let us note that Hooker attempts to persuade his audience that contrition is necessary; his method is to appeal to both their understanding and their affections. In a sense this aim is central to the whole work, for Hooker returns frequently to this theme. Second, he shows how God brings men to contrition: he enphasizes the importance which God has given to sermons, because according to Puritan doctrine the sermon is the chief means of conversion, and also: because Hooker wants his hearers to realize that the sermon which they are hearing may be God's means of calling them from their sins. Having established these two abases, Hooker. can proceed to urge men to meditate on their sing. He explains why they should meditate, how they should meditate, and what will be the results of their meditation. Reading, conferences, and more sernons Hookel also prescribes. When men have reached an "advanced stage in the contrition process they will, according to Hooker, receive a hope of salvation. - Encouraging the contrite to expect this hone, Hooker can then proceed to the last stem-by discussing the role of confession. Whth confession, the process is complete: man is saved, for he now has achieved a permanent hatred of sin 
which w1Il result in sanctification.

It should be noted that this summary of the steps in Hooker's description of the process of contrition does not follow altogether the order of Hooker's treatise. This is because Hooker seldom completely leaves a doctrine when going on to a new point but instead returns repeatediy to present new arguments. or re-phriased old ones to support the doctrine. The theme of the necessity of a true sight of sin can be found on almost every page. Hooker seems to have doubted that he could ever be certain of having convinced his hearers. Even the final passage is a last attempt to persuade his audience that contrition is the necessary means "of sanctification and salvation.

A second means of preparing the soul for salvation is humiliation. As we have seen, Hooker teaches that the soul is saved when it achieves true contrition, though the preparation process is not yet complete. 'The final step, humiliation, is necessary in order that the soul's reliance on itself may be broken, 92 for if a man honors himself he cannot trust in Christ; indeed, he will not even see Christ unless he sees no other way out of his troubles. 93 Iike contrition, humiliation is God's work; the soul is passive. 94

92 Soules Humiliation, n. 5.

93 Application: Blrs. I-VIII, pp. 153-155; compare Soules Humiliation, pp. 24. 25 .

94 Application: Bks. I-VIII, nu. 1iy-152; and sniles Hurniliation, 
When humliation is completed, faith is certain to follow, for the soul, though not yet saved, will be saved even if it die. 95 But humiliation, like contrition, is extremely difficult to achieve, 96 for the work of renovating a man is greater than the work of creation. 97

Hooker's position on preparation is, briefly, that preparation is necessary for salvation and is a saving work, resulting from God's special grace. 98 Hooker's teaching thus is similar to what witsius found to be not quite orthodox in the works of Ames and Perkins. But it is not what iniller refers to when he says, "Regenoration timrough covenant meant that men could make themselves ready, at least by studying the nature of covenants." 99

The most striking aspect of Hooker's teaching on preparation is surely not his emphasis on man's spiritual abilities; it is rather the creat difficulty of being saved. In later life Hooker seemed to consider this difficulty even Ereater. Like the Soules preparation, the tenth book of the

95 Application: Bks. I-VIII, pp. 152-153; and Soules Humiliation, p. 182 (misnumbered 282).

96 Soules Humiljation, pp. $232-21,2$.

97 Soules Humiliation, n. 50.

98 In The Soules Implantation, p. 34, Hooker suggests that an import tant result of preparation is that it makes man willing for Christ to enter his soul, and in The Unbeleevers Preparing, Pt. I, pp. 4.-1.1, he declares that to will Christ is a gift of erace and is necessary for salvation. Compare Application: Blrs. I-VIII, p. 153.

${ }^{99}$ Colony to province, p. 56. 
Application of Redemption is a treatise on contrition; here Hooker declares that contrition

- . will cost much labor and long time, before it can be done in an ordinary way; and therefore if thou art wise for thy soul omit no time, be faithful to do what thou canst, and yet fearful, because it's in Gods hand to do what he w111. Therefore seek seasonably, tremblingly, and uncessantly unto the Lord to do this work for thee. It's not the dip-. ping, but rubbing and soaking of an old stayn that will fetch it out; thou must soak and steep thy soul with godly sorrow. It's not salving, but long tenting an old sore that will do the cure. It may be it will make you go crying to your grave, and well if you get to heaven at last. 100

In some passages in Hooker's writings, however, there can be found demands that men prepare themselves by using "common" grace, and such denands are indeed of the same variety as those cited by miller. Whey are very rare. In the Saints Guide Hooker considers whether it is in man's power to make a sermon effective to him. He answers:

No, but it is in your power to doe more than you doe, your legs may as well carry you to the word, as to an Ale-house, your ears may heare the word as well as idle tales, you may sine as well Psalmes as Idle songs, you may read good books, as well as Play-books; doe you what you are able to doe, put all your strength, and dijigence unto it, and then cast your selves upon God, and tell his majesty, that faine jou would forsalke every ovill. way, but of your selfe you are not able, and though the spirit bee somewhat willing yet the flesh is weak spirit bei

100

Application: Bks. IX-X, p. 29.

101 Saints Guide (Lomon, I6h5), pr. $177-1183$. 


\section{In The Unbeleevers Preparing for Christ Hooker declares}

that. ". - we have no spirituall abilitie in our selves to performe any spiritual]. dutie, but yet we have ability to performe some morall actions; a man hath restraining and preventing grace whereby he is enabled to waite upon God in the meanes, that so he may be enabled to receive grace .. . 1102

But although such invocations to natural man's spiritual abilities may be consiclered seeds of the Puritan Arminianism against which Jonathan Edwards was to fight in the eighteenth century, 103 it is perhaps more useful in studying Hooker to consider them agrinst the background of "High Calvinjsm." Puritans such as Henry Smith did not emphasize predestination and man's inability neer]y as much as Hooker. did. Hooker's problem was to preach conversion sermons at a time when the orthodoxy with which he identified himself insisted on the centrality of the roctrines of inability and predestination. ilith this framework Hooker had to rely on such doctrines as that of common grace in order to remain at the same time an effective preaches and a strictly orthodox theologian. 104

\section{Pt. I, p. 120 (misnumbered 220).} $103_{\mathrm{As}}$ niller considers them, in "ivarrow," w. 286.

10l-Hooker's views on common rrace noe in ract similar to Calvin's. Calvin taufitit that ". . a certain common grace is eranted. - to tol. those who th the times of the New Testament dispensatjon live in the onvenant sph iee, to all the believers and their chlldren, to all who in any 
Let us consider some passages in Hooker's writings which demonstrate his consciousness of his delicate position. Hooker considers a possible dissuasive from the doctrine of means:

- - some may cavill now and say, Gods mercy is free, and therefore hee may as well deny it mee as bestow 1t upon mee. I answer, this is true, hee may deny it thee as well as give it thee, and he may also as well give it thee as deny it thee; it is as possible that thou mayest receive mercy, and therefore try all meanes possible to obtajne it. 105

Although Hooker here may not answer the objection to the satisfaction of the modern reader, it is significant that he felt the need to consider the objection at all.

If some people who seek God never find Him--the orthodox Reformed position--then why should men try to seek Him? D. "Reason thus," answers Hooker,

Is it so, that those who seeke the Lorde shall never finde him, then what silall become of me that never cried at all, nay, that loath prayer, and reject the use of Gods ordinances, and dispise the meanes of grace and salvation, whereby $I$ inust seeke and obtaine mercy if ever I have it.. . my condition

sense may be accounted members of the New Testament Church." This includes even those "who have a name and a place in God's Church in distinction to those who have never come into touch with. "the means of grace." Note also that according to Calvin's teaching "God in various ways manifests his goodness to men at large in order that he may turn them from their sins and allure them to Himself. . . God woos men to Himself and urges them to come to repentance. •.$"$ - Herman Kuiper, Calvin on Common Grace (Goes, Netherlands,

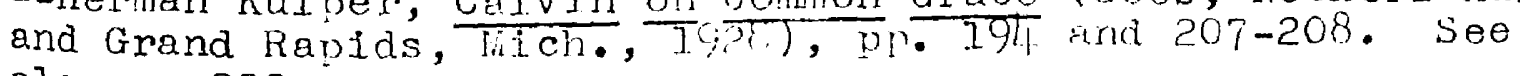
also p. 222 . 105 Unbeleevers Prevaring, Pt. I, p. 22 . 


\section{is desperately lamentable, fearfully irrecoverable}

Hooker seems altogether consclous of the awkwardness of his position in these attempts to get around the difficulties supplied by the extreme doctrine of predestination.

Hooker would not have resorted to the doctrine of common grace in exhorting his hearers to go to church, hear sermons, sing psalms and read books, except for the fact that the strict orthodoxy of his day rieidly insisted on man's spiritual inability; cominon grace was for Hooker a loophole which he could use in persuading his hearers to "use the means."

Let us summarize the conclusions reached so far concerning Hooker's techniques in preaching conversion. Because of the Puritan theory that preaching is sacramental in nature; the strict predestinarian Hooker could nake Arminianlike demands of his hearers. These denands include exhortations to prepare for salvation throurh contrition, which is, according to Hooker; God's meons of saving the elect.

Although Hooker may be classer as a covenant hileologj-" an, especially in his teaching on buntism, covenant theology does not differ from time teaching of calvin in the respects that Perry lijillep has suerested. Whe thonry of the sempon

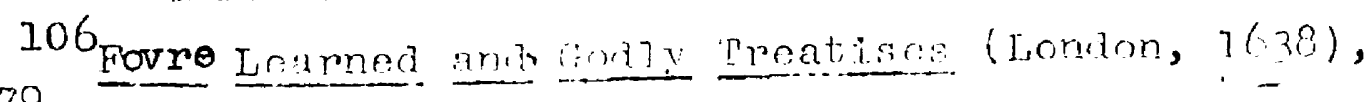
p. 279.
} 
as sacramental is more useful than the covenant idea in understanding Hooker's teachings on conversion. In the next chapter, we shall examine other aspects of Hooker's technique in preaching conversion. 


\section{CHAPTER V \\ ADDITIONAL PREACHING TLHEIWUES USED BY HOOKER}

Having examined Fooker's teaching on preparation and some aspects of his preaching technique, we shal I now consider, against this background, severa]. other techniques which Hooker used repeatedly. One of the most interesting is the argument that if one fails to "use the means"--fails, that is, to follow the prescribed program of preparation which will result in conversion--he is actually resisting erace. This concept, evidences of which we have al ready observed, is clearly a result of the Reformed and Puritan doctrine of vocatio or éfectual calling. Heppe points out that in Reformed teaching ". . . the word by which the H. Spirit [sic] effects calling is the same word by which lod's cåll to grace is outwardly proclaimed to man."I If preaching is God's means of effecting calling, one could easily argue that to resist what is preached is to resist God's grace. Presumably this was Hooker's reasoning. Further, as the Reformed divine vollebius puts it, "The form of this calling consists party in the offer of the benefit of

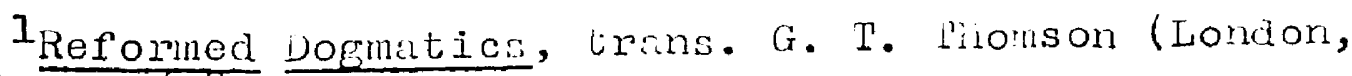
$1950), \frac{1}{\text { p. } 510 .}$
} 
redemption, partly in the injunction to accept it." 2

Hooker's Insistence that men accept grace by using the means to obtain it is thus orthodox in the Reformed view.

Hooker's task was, we must remember, to persuade. If we keep this in mind, we shall be less troubled by Hooker's seeming inconsistencies. For example, Hooker commonly holds that man cannot believe without grace, but in The Saints Dignitie, and Dutie he labels those who aro unwilling to beIieve as horribly base, and those unable to believe as horribly unfaithful. 3. Name-calling is used here to persuade; it is intended as an injunction to believe. Hooker even has two sermons which attempt persuasion by name-calling: "CuIpable Ignorance" and "Wilful Hardnesse." 4

In another work Hooker calls "resisting God's Spirit in the Word" (failing, that is, to follow the preacher's instructions) a sin next to the unpardonable sin, for it is, in a sense, a sin against the Holy Ghost 5 "in a more than ordinary manner." 6

So when God hath sent his faithful jervants to admonish thee, his ininisters to convince that

${ }^{2}$ Christianae Theolopiae Compendium (Basel, 1624), p. 90, quoted by Heppe, Dogmatics, p. 515 .

${ }^{3}$ Saints Dignitie (London, I65i), p. 90.

4 Both in Saints Dignitie.

5The Soules Vocation (London, 1637), pp. 67-68.

6he Application of Redenption: The inth and iderth Books (London, 1657), p. 95 . 
gainsaying spirit of thine, to ransack the cormuption of thy Cankered Conscience, so that the core might have been searched, and thy distemper healed. Who knows what might have been wrought, what benefit thou might have received, hadst thou but suffored and received the helps provided for that end; which when thou diddest oppose, and not suffer thy self to be convinced, thou didst oppose thine everlasting welfare, and therefore art guilty of thine own blood.

Here Hooker extends his indictment of the unconverted: first, they are guilty of resisting God's grace, and second, they are committing spiritual suicide by being unwiling to be convinced. "Io' be hard to' be convicted [of sinfulness] is a dangerous sin, and a dreadful curse to the party that is tainted with such a disposition of spirit." 8

Thus the chain of "Iogic" which we have traced leads Hooker to suggest--again for persuasive purposes--that if a man is not effectually called, he is at fault:

If a bungling servant cannot tell how to hew a peece of wood for a building, it is no marvell; but if it be such a peece, that the master Carpenter cannot make it fit for the building, then it is good for nothing but to be burned: So it is here with the soule, if tine spinit of God can doe thee no good, who can?

ilore often Hooker is less denunciatory, nore imploring: "If you vill, but comc and take grace, that is all God lookes. for, ali that the Lord expects and desires, you may have it,

\footnotetext{
7 Application, Bis: Ix-K, p. 94 . 8 Application, Bks. IX-X, p. 94.

${ }^{9}$ Soules Vocation, p. 69.
} 
for the carrying of it away . . . "10 Christ wants man to obey His commands and live forever: ". . . he desireth it heartily, and he will be exceedingly pleased if you satisfie his desire."Il Christ so wishes for man's salvation that ". . the Lord tyres himselfe. . . and wearieth himselfe with waiting one day after another. . . . "12

Although Hooker appears to have based his teaching on accepted Reformed doctrine, both his denunciations and his solicitations are quite possibly suspect when compared with orthodoxy. But as a rule Flooker departed only slightly from Reformed theology in his invocations to man's ability. One interesting strategem which Hooker employed frequently was to describe the redemptive process in terms of what might be called minimal voluntarism: that is, Hooker holds that only a very slight spiritual effort from man is necessary for salvation.

The Gospel doth not require a lian should Beleeve of his own power, but tiat he should be willing and content to be made able to Beleeve and Partalse of that Grace he is called unto.

Such an arrangement is possible beccuse to many sinners

God affords means, so that if they wil but subrit to the Gospel and be content to receive Grace they shal

10 The Unbeleevers Preduring for Cirist (London, 1638), Pt. I, $\overline{\text { p. }} 20$.

${ }^{11}$ Saints Dignitie, r. 151 .

12 Unbel eevers Prepbring, Pt. II, p. 38. 
not want it, and that Adam could do and we in him.13

Although Hooker makes clear elsewhere that in vocation "the Spirit makes us willing that we may will it [grace]," 14 here Hooker unquestionably preaches a dilute form of voluntarism. Elsewhere Hooker's voluntarism is based on much the same pattern of thought. In The Saints Dignitie Hooker's approach is based on three considerations. pirst, ". . Gods Commandments are above the power of nature to obey: nothing [is] harder... [for] corrupt infirm nature lto perform I than Gods Commands ..." (page 84). But nevertheless man's disobedience is "without excuse." There is a. method which man can follow so that he may fulfill the Commandments: "The onely way to be able tó obey Gods Comnandements is to beleeve... all strength to obey commeth by promise, the promise is made ours by beleeving, there is no way therefore to obey but by beleeving" (page 88). Another of Hooker's conversion techniques relates to his teaching on resisting Erace and seoms to be, in its universalist implications, even less orthodox. Frequently Hooker teaches that although man may refuse grace now, " thinking to accept it later, "there is nothing more crosse and contrary to the power of Erace... . 15 "The basis for

${ }^{13}$ The Apolication of Redernution: Hinc first oignt Books (London, 1656), pp. 60-61.

14 The Covenant of Gruce Openod (Lomon, 1649), p. 16. ${ }^{25}$ Soules Vocation, p. 537 . 
man's reliance on his ability to accept gracé is, in Hooker's view, the fact that ". . the Lord stands, and waits, and knocks, if any man will open.. . he [will] call till he be hoarce, and knock till he be weary. . . ."16 But Hooker warns his readers that ". . the Lord is not at thy call, he will not give thee grace when thou wilt, but when he pleases . . . "17 God will call repeatedly, but His patience is not endless.

On the basis of this idea, Hooker built a doctrine which appears to be very close to Arninianism--apparently for the purpose of universalizing his message. Since ". . every man hath a day and a season wich is the harvest of salvation, doe you not take notice of this, that at some Sernon God opens the eye and prickes the conscience... this is thy day, take heede how thou neglectest it . . . "I8 God gives every man a Iong time during which to repent, after which time if he has not repented,

The Lord ceaseth to strive with sinners anie more, he takes either the ileanes rrom them, or them from the meanes, or his blessing from both. God hath bounds of his bounty and patience, hitherto and no farther he will strive, but not alwaies: when his time is expired, not a jot of a minute is further to be expected. . - Gods season of mercie doth not alwaies last; there is a Terme time and a vacation. - - 'ine Lord malce us wise to know the day of our

16 Soules Vocation, p. 542 .

17 Soules Vocution, pu. 54.5i-54.6.

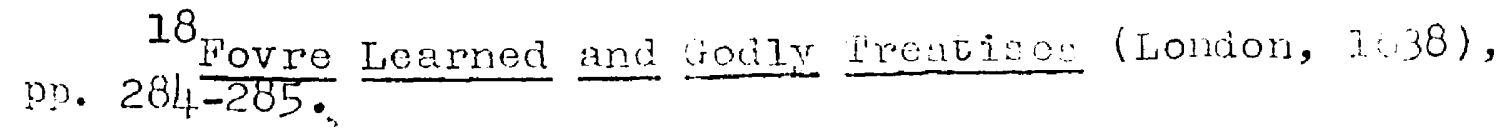


visitation, least he remove his Candlestick frorn us, and he be seene no more, least he in his wrath goe away, and leave us to die and perish in our sinnes. 19

Effectual calling here becomes a mere visitation.

The purpose of this teaching is clear enough. It enabled Hooker to warn that the day of salvation is not in the future, but now while ministers are calling and the sinner is still alive. 20 Hooker has an entire sermon devoted to the theme of "redeeming the time." In this work Fooker directs:

- .'wher the Lord strikes, strike thou; when the Lord moves, inove thou. As winen thou hearest the word, and art convicted by it, and thy heart begins to move: oh then, that's a season. wake hay while the sun shines: follow the blow, and breake thy heart, and humble tiny soule!2l.

Phis is one of the most Aminian-like passages in Hooker's v'ritings, and seems to be a natural consequence of his teaching that every man has an opportunity to be saved. If not orthodox, Ilooler's teaching is, in a sense, practicaI.

But in another treatment of the thene, Hooker's practical purpose, if he had one, is obscure. It is understandable that Hooker should charge that if men do not accept grace now, God nay harien their hearts later so that they

I9 prie Saints Guidie (London, 16it5), pi). 20 Unbeleevers Preparing, pt. I, p. 174. 263.

21 Phe paterne of Perfection (London, 16\%0), pp. 262- 
cannot accept it, 22 or He may not offer it again. 23 Hooker meant to be persuasive. But it is less clear why he should argue that if men try all the approved means to obtain grace and fail, it is only because they had refused it earlier. 24 Presumably Hooker wished to discourage procrastination, but it would appear that he did so at the risk of discouraging some of the unconverted from trying to use the means. Except for this point, which Hooker makes only in passing, the intention to persuade can be clearly perceived to underlie Hooker's warning against resisting grace.

One of Hooker's most interesting conversion techniques is concerned with the related doctrines of the perseverance of the saints and assurance of election these doctrines are of course not properly redemptive doctrines as are the doctrines of justification and vocation. But al though in Hooker's teaching the conversion process is crucial for the unconvented, Hooker seens to have attached almost no significance to it for those who regard themselves as "beleevers." we have seen (in Chapters I and II) the frowing concern with assurance in Reformed and ruritan theology; Hookér's position is the logical extrene of the doctrine, for he would never have a sinner assume that he is called; instead, man must always be testing his election. Pesting becomes in his

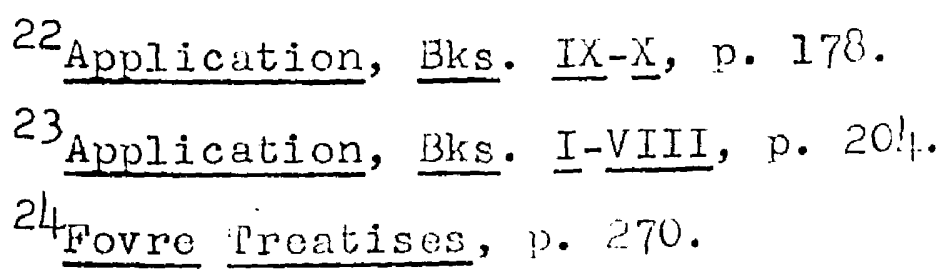


teaching almost a redemptive process.

However, Hooker assuredly teaches that man can have definite knowledge of his election. Such knowledge is avallable. 25 God makes man "see by particular evidence, thou shalt be pardoned, and thou shalt be saved; this particular notice." 26 God can even be said to make with the soul "a kind of ingagement" that it shall be saved. 27 God uses His ininisters as His means of informing sinners that they are saints. 28

Occasionally Hooker makes perseverance depend on man's own ability and argues that a soul which has been ingrafted into Christ, "if it be not negligent of its owne salvation, cannot lose that fitness [ror the service of Christ] altogether, and the Lord Jesus cannot lose that giory which he expects from 1t."29 Apparenty a saint can persevere, but

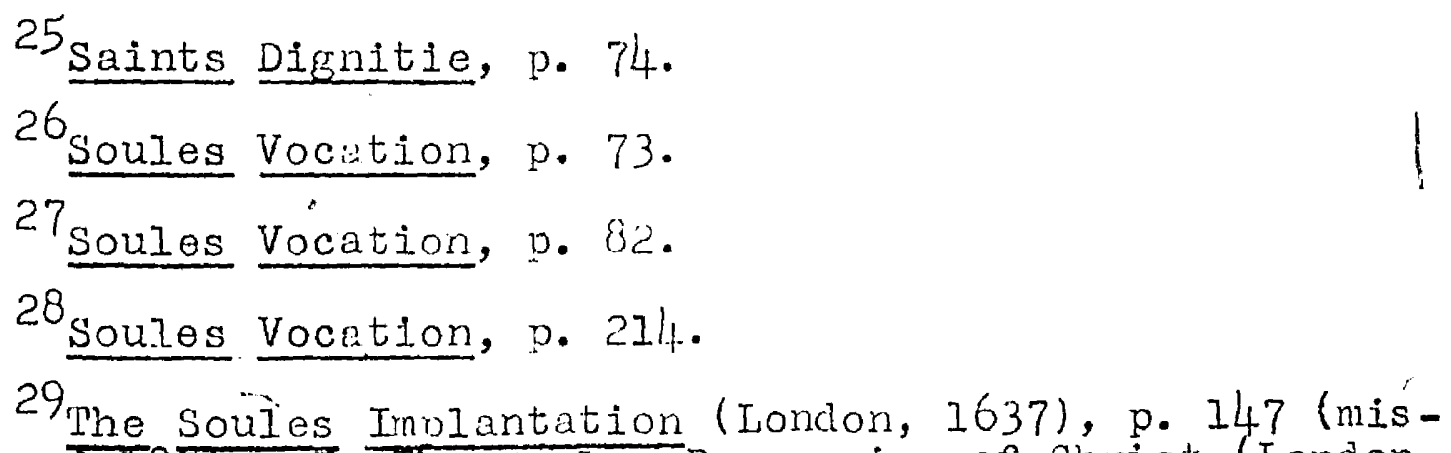
numbered 187). In The Soules possession of Christ (London, 1638), a treatise on sanctification, Hooker addresses the elect as follows: ". . If you vilil not have God take away your sinnes, the truth is; God will tare away, his grace and holy spirit froul you, if you ever liad it: ivay, you shall never have it upon these terios"-ip. 163. Here iooker soems to havo reneabored belatedy the doctrine of perseverance. It almost seems that he is miting cod's election depend on foreknowledge or how the saini, will use he grace gi ren him. Compare Application, Bks. IX-K, p. 299, wiere Hooker says that God denjes the contmunicution of ine neins to some who 
to say that he will persevere would permit relaxation of one's spiritual muscles.

At times Hooker goes even beyond Calvin in demanding that his hearers--or rather, some of them--believe themselves to be saved. If a man is truly contrite and yet does not think himself saved, he coninits the sin of pride, for both reason and ministers say that the truly contrite are saved. They who disagree follow their "owne conceit and selfe wilanesse of spirit." 30 Elsewhere Hooker lists in detail the sins comritted by those who do not acknowledge--as they should--that they are called saints. First, these people break the Phird Commandnent by denying what God has done. Second, they commit spiritual mayhem by wounding thelr own souls. Third, they are thieves who rob themselves of comfort. Fourth, they bear false witness against themselves and Christ and the froly spirit. 31

All of these invitations to assurance are, however, unusual in Hooker's writings. Wuch more comnonly Hooker teaches that nothing is moro important to nan than "selfetriall," for many who die thinking they are saved go instead

would use then to better advantage than some who have them. And in $A$ briefe Exposition of the Lords Prayer (London, $1645), \frac{p}{20}$, Hooker argues that in those effectualiy called Christ "sets up that frane of spirit, wereby it iman's heart] is subject to grace. . . "

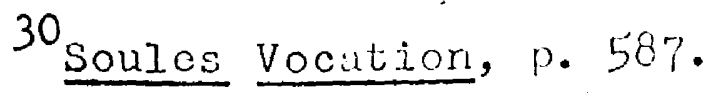

3I"The Poore Dovbting, Ghristian Jrune Vnto Christ," in Richard Sibbes et al., wie Uants Cordials (London, 1629), pp. $353-354$. 
to Hell. If people would only see that their hopes of salvation are false, "there were a great/deal of likelihood that they would obtain true grace, and so consequently come to be everlasting saved." 32 This seems to be a definite refusal to accept the Reformed doctrine of predestination. Hooker's teachings on assurance, especially in his later works, such as the Saints Dignitie and The Ghristians Tvvo Chiere Iessons, were probably to some degree affected by the teachings of Antinomianism, which arose in New England about 1636.33 According to Mrs. Anne Hutchinson,". . no works could have anything to do with justification . . they could not be offered as 'evidence'... [and] a true saint might consistently live in sin. . . "34 Similar doctrines had been taught by the sixteenth-century Anabaptists, and Calvin had answered them by insisting on the inevitable relationship of justification and sanctification. 35

${ }^{32}$ Saints Dignitie, 0. 67. A similar idea is expressed in The Christians Tvvo Chiefe Lessons (London, 1640), p. 112 (misnumbered 212).

33For Antinomianisn, see perry willer, the livew England iind: The Seventeenth Century (Canbridce, hass., 1954), pp. 369-371, 389-391, and passim. hereafter cited as seventeenth Century. However, as we have seen, Perkins taught the need of self-trial. Conpare also the teachings of Richard Rogers, Richard Greenham and others in $A$ Garaen of Spiritual1 Flowers (London, 1620; first tilition, I605).

34 miller's sumbry, The New ingland ind: irom Colony to Province (caibridge, $1 \mathrm{ss}, 1,153), \mathrm{p}$. 59.

${ }^{35}$ See tire Instituten, trans. H. Sovoridge (Lonron, 1953), BK. III, Chan. 3, section xiv. 
Hooker's answer seems to have been that while saints may achieve assurance of election, it is best that they continually test themselves, just to make absolutely certain. 36

Let us look at some of the tests which Hooker proposes. In The Christians Tvvo Chiefe Lessons, he begins his discussion of one aspect of "selfe-triall" by agreeing that "There is a possibility revealed of God for man to know whether he be called of God, or not; it is attaineable for a man to know whether he be in the state of grace, or remain still in his naturall condition." 37 But he immeditely warns his hearers: "Let the unspeakeable comfort that issues from this assurance, the endlesse joy that arisetin hence, make us carefull seekers of so eroat a benefit." 38 litan may be conlused about his true spiritual conrition because of his spiritial blindness and Satan's deceptions. Further, God nay withdraw is presence rron the saint to punish him for neglikence or to keep pride and security from his heart. 39 iherefore ". - everrone that lives in the Church is bound seriously and with great diligence to try [test] and examine

36 Hooker's teachings on assurance are very different from the teachings of the covenunt theologians of New angland as described by willer: ". . union with God promised to be no more a torturing uncertainty, but a definite legal status [in the covenant of grace], based on quid pro quo." Seventeenth Century, p. 389. Hooker's teacilings must have resulted in definite uncertainty.

37 Lessons, p. 104 (misnumbered 204).

38 Lessons, p. 105 (mismumbered 205).

39 Lessons, pp. 106-110 (misnumbered 200́-210). 
his estate, how it stands betwixt God and himselfe, in respect of the worke of saving grace wrought in his soule. 140 Hooker then volunteers to supply directions for the performance of this "duty."

He uses two techniques, one negative, one positive. First he discusses "false shadows of the state of grace" as demonstrated in such types as the, "Civill Kian," the "Formalist," and the "Temporary Professor." These sketches, like those of the seventeenth-century character writers, are filled with vivid details of contemporary life. Each is an attempt to reveal to those present the ways in which they may be decelving themselves concerning their spiritual state. 41

Then Hooker presents the four "essentiali parts of him that is in the state of erace." These are faith, godly sorrow, change of mind, and new obedience. Hooker insists that one's faith must be great if it is to save one. One must have "a constant earnest desire of the pardon of sin flowing from an humble heart, joyned with a conscionable use of the meanes ... . 142 If one has such a faith, he will know by the "marks of faith": a pure heart, a profound feeling that he lacks grace, a corresponding desire for grace, contentment in all his states, and a continues wrestling with doubt.

\footnotetext{
4.0 Lessons, p. 11.1 (misnuinbcred 211).

41 Lessons, pp. $113-1 / 6$ (misnumbered $213-216)$.

42 Lessons, p. 14.8 (mis numbered 24,8 ).
} 
Apparently one can be sure that he is saved if he thinks he is not. A further mark of faith is that it must have come through the use of the means. 43 when it is remombered that Willian Perkins judged a vague trust in God to be saving faith, we can see how strict Hooker's teaching is.

If one has godly sorrow, he will. have a deep displeasure at his sins and actually weep--often--for then. He will of course be extremely careful to dvoid all future occasions for sin. Hooker then presents additional marks of godly sorrow, and also deals with change of mind and new obedience. 44

How does one know whether or not he is effectually called? Hooker's answef is that those vino are called demonstrate their spiritual health in many particular ways. If one believes in Hooker's theology and regards himself as called, how would he react on finding that he does not "perforn" as Hooker says the elect should? He would attempt to do what Hooker contends the elect do. If he were successful in his efforts, and continued throughout his life to use Hooker's testing method, he could feel assured of salvation." Further, he vould demonstrate to hinself tint he had been called by following what many traditional, non-predestinarian Christians have prescribed as - tire lay to salvation. Ine process of testing one's self thus vecorles equivalent to the

${ }^{43}$ Lessons, pp. 150-15\% (1is number $\left.250-254\right)$.

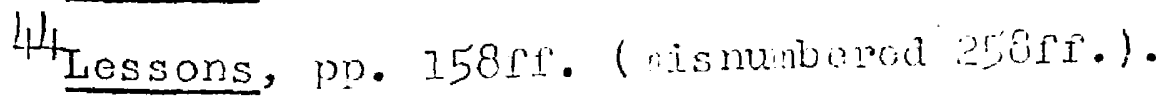


redemptive process in the teaching of Thomas a Kempis, for example.

Let us consider another of Hooker's works, the Soules Vocation, in order to examine further the self-testing idea. Here Hooker declares that if you truly love God, "if there be ever. a Saint in heaven, thou art one now, \& shall be in heaven for ever hereafter" (page 236). Such being the case, "How shal I. . know ny love, whether it be true, of the right nature or no?" (page 237) Hooker prescribds five "trialls": (1) True love of God is spiritual and is not based on God's mercy and goodness to the lover, for such love'is in reality love of self. God must instead be loved for his attributes. 45 (2) The true lover of God loves prayer and semnons, and despises honors and riches. (3) the true lover tries to make God happy by following His wishes and never doing what would aispleasé God. (4) ine true lover's greatest joy is the pronotion of the rospel. The true lover of God greatly desires a closer union with Hirn (pages 237-255). Briefly, if one is a "saint" in the predestinarian sense, he vill act like a "saint" in the modern serise.

45 Thus Hooker's position How is dianetrically opposed to Calvin's. See Chapter I for Calvin's views. But in Soules Implantation, p. 266, Hooker declares, ". . if you Will not love hlm [Christ] nor his srace or mercy, yet love your owne solves; deny not bis cracious offor, lest herearter you seeke for love, and mercy, and compassion, and beo refused and condemned for ever." 
A similar test is prescribed for true faith. The true believer can test his faith by seeing if it is from heaven: Is it "put. . into our soules by hearing" the word? 46 Is the believer willing to be disgraced for Christ and even give up all his Iusts for Christ? Does he regard honors and all worldly things as nothing, the promises of the gospel as everything? If so, he has faith and is saved--but, of course, it may be only a temporary faith, and so he must continually try himself. 47

Hooker's teaching that man must love God for' ifis quality of goodness and not for any good done to the sinner is reflected in another concept in his teaching, his belief that no man is saved unless, in the redemptive process, he sees that he deserves damnation and is even willing to be danned. In that part of preparation devoted to humiliation the soul must reach the point of saying, ". . Iet me be damned, so thou maist be Elorified."48. The soul wili, however, continue to seek mercy from God even while it is content to be damned. 49 l.

Now the soule boing beset with Gods wrath, in conclusion seeth he cannot escape the Lords hands; and how to purchase"mercy lie knoves not; nor is it

46 Soules Vocation, pp. 424-4,27. 47 Soules vocation, pp. $427-434$. 48 Soules Vocation, p. 2li.

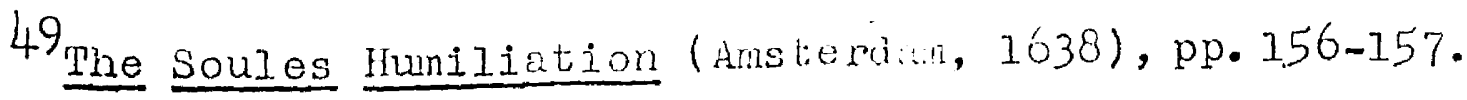


possible otherwise for him, to escape, and yet he hath nothing to purchase mexcy withail, therefore he is content to Iye downe before God, saying, I iconfesse I have sinned, Oh Lord bee thou glorified, though I be damned for ever, my sinnes are so many and so vile, I cannot almost desire mercy, but if the Lord will, who can let hin? 50

Such a state of mind must surely be hard to achieve; in the twentieth century one finds much the same mental outlook labelled, by George Orwell, "double-think."

This demand that one be willing to be damned makes a strange combination with Hooker's declaration that "... the Lord hath sent from heaven this day, and offered salvation and happinesse to men, as freely as ever any nan had anything offered."5I Willingness to be damned is presumably the height of happiness.

Although the iliea of willingness to be damed appears in several of Hooker's vorks, as a preacher concorned with persuading his hearers to use the means of salvation Hooker was comonly moro interested in painting an atiractive picture of the rewards wich the saint will recoive. is we night expect froril our carlior observations on the paucity of eschatology in puritan writings, the joys of salvation winich Hooker describes are nearly always to be achioved in this world. First of all is of course the assurance of election. other joys are often peculiarly intangible: "all spiritual

50 Soules Implantation, p. 168.

51 Unbeleevers preparime, Pt. I, : 77. 
benefits, "52 "unconceivable good, "553 "unsearchable riches."年 Occasionally a more specific detail is given. "It is pleasant and comfortable... God will come and sup with them that follow him. There are no wants, but rivers of pleasure and delights... " 55 viore precjsely, Christ will deliver the saint from sins (if he requests deliverance) and provide spiritual comport. 56

The thome of the early part of line soules Implantation is tirat a saint is "vith Christ" and tims is in heaven. But later in the same work Hooker admits, rearlily, that he who poscesses Christ may not. know it until the hour of death: ". . many a poore Saint of God hath smoaked out his dayes in doubting and making question of Gods mercy and goodnesse ... ." (page 134). Too often the saint expects "some extraordinary sweetnesse" to be felt when his soul is possessed of Christ; then wen the feeling is not experienced, he misjudges tine presence of christ (nage 120). It would appear that Hooker was at lenst in jart at fault if a saizt expected such distinct sensations. OnIy a few jages later he doclares,". . there is a sweetresse andi a relish wilch

52 Application, Bles. I-VIII, p. 6.

53 Soules Implantation, p. 26!.

54 Lessons, p. 62 .

55 Lessoris, 1.33.

56 Soules Implantation, no. 11,-1/5 (nisnumbered 184185). 
Gods love lets into the soule, and wames the heart with .." (page 176).

When one is disappointed at the experience of possessing Christ, it is "as if some Gentleman should receive the King into his house, and yet would not be persuaded the king was come, because he did not presently send for him into the presence charnber, and advance him to some great place of honor: he is there though he will not presently send for you. "57 One wonders if, when He comes to sup with the saint, Christ prefers to eat in His om room, privately. In discussing the joys of salvation, Hooker pictures them attractively to the unconverted as an incentive to use the means of salvation; to those who are already called, he explains why they nay not f'eel Christ's presence. It may be because they have sinned seriously because the saints grow careless and secure; fulling to perceive Christ's presence then serves, to draw the soul back to Christ. Or it may. be that God fears that tho saints "should be proũd . . and pranke thenselves in regard of priviledges. 158

Hooker's tecinique in dealing with the joys of salvation is very similar to his treatment of conversion and as surance. For the unconvorted, conversion is depicted as the ultimate goal, but the corverted nust continually test their election. Salvation, you will find, results in great joy,

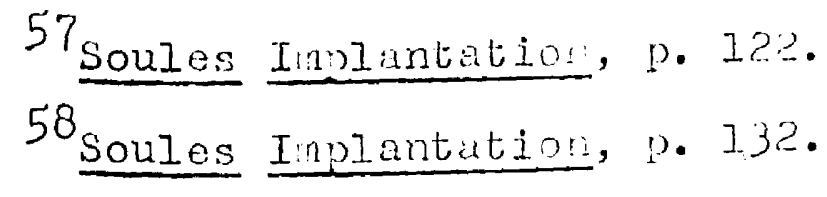


but do not be disappointed when you find that it does not.

In contrast to the theology and teachings of Hooker and the preaching techniques which he developed from them as described in Chapters III and IV, the methods which have been analyzed in this chapter often appear heterodox and not altogether legitinate, al though each bears a close relationship to Reformed doctrine. Hooker's heterodoxy on the points which have keen aiscussed revolve around two central concepts: First, Hooker wished to make conversion seem easy and attractive; therefore he went even to the point of contending that those who had not been called were actualiy guilty of making successful efforts to resist God's grace.0 Yet at the sane time, the conversion mocess which Hooker describes is in fact a long and difficult procedure, with sonewhat uncertain rewards, at least in this life: second, in the face of the Antinomianism which had spread from old to Niew ingland, Hooker enphasized even nore strongly than had earlier Puritans the need ror the saints to test thein election by careful exanination. llooker pusined this concept to the point where, in his thought, conversion cane to be of little importance to the saints, although j.t renained vital to the unconverted.

Thus we have two basic discrepancies within llooker's teachings, and while it is true th:t tire ronsons for these discrepancies are not nir to sent il is clear that looker's 
importance as a religious thinker is diminished by these findings.

Having exanined in some detail Hooker's thought on conversion against its historical backeround, we can now profitably turn to some of the writings of thomas shepard and John Cotton, with the expectation that by comparing their techniques and teachine with Hooker's, we shall be able to reach some general conclusions about Thomas, Hooken's rélationship to the theology and preachine nethods of the other New England Puritan preachers of the rirst Eeneration. 


\section{CHAPSiR VI

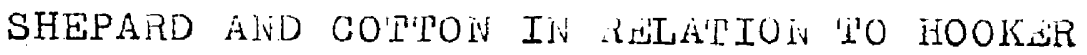

In exanining next some of the writings of John Cotton and Thomas Shepard, we shall not attempt to describe fully the theology and techniques of each divine. 'Rather we'shall try to see wherein they differ from Hooker's theology and techniques. Such an investigation has at least two values. First, it should enable us to see how far Hooker's teaching inay be regarded as troical of early lew sngland Puritan teaching and to see to what derree there can be said to have

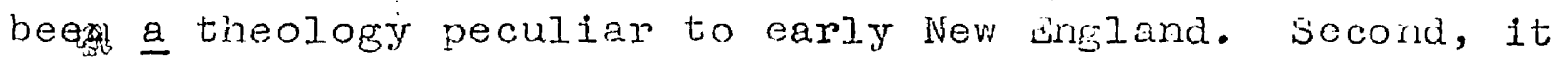
should put us in a betier positjon to evaluate liooker's’ comparative stature as a puritien divine.

$b \mathrm{~s}$

\section{Thomas sinenara $(1605-1649)$}

of thé writings of tié eärly Now ingland preachers, Thoinas Shepard's worls have been inost renetrbered. In tihe seventeenth century'nineteen editions of Shepard's I'he Sincere Convert were publisined; in the oighteenth century his works continued to be remrinter and sone of his vritings were translated into Gor:n tor the bonolit of remisylvania settlers. In $1853 \mathrm{his}$ worl:s vore mil ined in a three-volune 204 
edition. In scotland, where his writings have been widely read, Alexander Whyte, Principal of New College, Eidiburgh, and noted preacher, published in 1912 a series of lectures called Thomas Shepard: Pilgrim Father and Founder of Harvara. 1

The most important modern study is by Karl. Olsson, who has studied shepard's thought thoroughly and wisely. ${ }^{2}$ But his stpdy considers Shepard's teachings in a vacuum, without relating him either to the Reformed treology or to other Puritan divines. Little use has been made of Olsson's findings in the present study, which atternts to be historical and comparative.

One aspect of Shepard's teaching is interestingly similar to Hooker's concept that by resisting God's ministers, man resists grace. Shepard confuses even more completely than Hooker the standard Réformed distinction between general or outward calling by means of preaching, and particular or inward calling by means of the working, of the Holy Ghost.

${ }^{I_{\text {See }}}$ Babette Hay Levy, Preaching in the Pirst Half Century of iNew Engländ History (Hartford, I9t5), pp. 144-145; and Donald wing, Short-1'itie Catalogue, $1641-1700$, s. v. "Shepard." Shepard's connection with Harvard is explained by Cotton wather in the following fasinion: ". . it was with a respect unto this [Shepard's] vigilancy, and the enlightning and powerful ministry of inr. Shepurd, that when the foundation of a colledge was to be laid, Cambridge rather than any other place, was pitched upon to be the seat of that happy seminary - . "-- - inagnalia Christi Americana (Hartford,. 1820), I, $3 \dot{4} 8^{\circ}$.

2 "Theology and Rhetoric in the-vritings of tho.las Shepard," unpub. diss. (Cricago, I9! 0$)$. 
By faling to make the distinction botween the two callings --or two aspects of calling--Shepard can state,". . the Lord calls all in general, and consequently. each man in particular..." "3 The identity of the inward and the outward call is thus proclaimed by shepard:

Consider who it is that doth call-you; is it van or winister think you? you might never come then; no, it is Jesus Christ himself that calls you by them. Why do many discouraged spirits refuse to come? it is because they think deceitfuli men, or charitable men call them... I tell you their Ministery is not an act of their charity, wishing well to the salvation of ell; but it is an act of Christs love \& soverelgne Authority . . . 4

It is not difficult to see how shepard, by identifying the two callings, can call rejecting God's agents, His ministers, "a bloudy sin," "a most Dishonouring. sinne," "a most ungrateful sin," "a most inexcusable sin."

Hore peculiar than this downright theological confusion is another passage from Shepard:

- doe not say I am not able to cone Lto Christ], and therefors, I am not called; no nore are you able to attend the rules of the worall Law: yet you looke upon them as appertaining to you, \& because you cannot doe them, you entreat the Lord to enable you, and so because you cannot come, you should looke up to the Lord to draw you: and verily many times the Breat reason why the Lord doth not drawe you is, because you do not deeply consider that he doth really

3 The Sound Beleever. (London, 1652), p. 245.

4 Beleever, p. 21,4 .

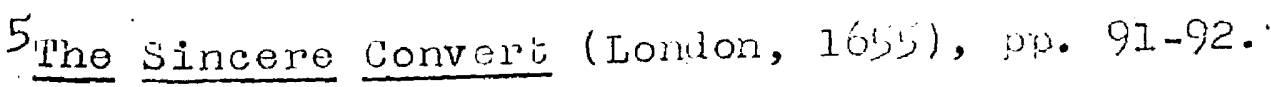


\& affectionately call you ... 6

Here shepard scems to be saying that men who regard themselves as uncalled because they are not able to respond may be unable because they do not, as they should, regard themselves as called. Confusions of this sort arise frequently in Puritan sermons--indeed even in Calvin's works 7--because. of the difficulty of reconciling hum responsibility and divine predestination. In this passage shepard holds man responsible for not being called, al though he might have contended that he was only trying to persuade men to use the means of salvation. While other'preaciers tried to avoid the difficulty by such methods as holding the sermon to be a' means of grace, Shejard Tilore often tried, to transcend the difficulty by verbal solutions, sone expressed with spirited eloquence.

In spite of these confusions, shepard in the same treatise distinguishes tho two callings: the minister's call is general; particular calling is by.the Floly whost. ${ }^{8}$ If

6 Beleever, p. $24,6$.

7 See the Institutes, trans. F. Beveridge (London, 1953), Bk. IV, Chai).3, section 1: "but wien a reeble man la preacher], sprung from the dust, speaks in the name of God, ve give the best proof of our piety and obedience, by listening with docility to his servant . . ."

8eleever, pp. 191-192. In anotien. worl Shepard states even more distinctiy the orthodox Reforned doctrine. "There is Gods extemall or outwerd wort, contilining lotters and syllables and this is his eytornall voice. - . irere is Gods internal word and voice, winch speals to the heart, 
the Holy Ghost calls particular men, His calling is apparently not irresistible, for ". - if there were not such a particular" call, then men should not sinne by refusing the Gospell, nor should the Lord be angry for [their] so doing -. .119

Perhaps we shall be better able to apprehend this aspect of Shepard's preaching technique if we examine his own explanation. "He identifies, as do other Puritan theologians, the call to come to christ on the one hand, and, on the other, the offer of christ, the acceptance of which constitutes vocation. Then, he considers the three parts of this call or offer:

1. Commandment to receive Christ as present and ready to be given [to the soul]: as when we offer any thing to one another, it is by commanding tiem to take it....

2. Perswasion and intreaty to cone i receive what we offer: for in sucl an offer wherein the person is unwilling to receive \& we are exceeding desirous to give, we then persuade; so doth Christ with us. 3. Promise; to offer a thing without a promise of having it, is but a mock-offer. . . 10

Here we have Hooker's teaching simplified. 'ilhe only nention of the inward calling in the description is in the persuasive aspect of calling, and therein christ is said only to

even when that only speaks in the externall word, when that only speaks to the tear. - : The other [internal word] comes to fow, who hear not only the word spoken, but God speaking the word."--Subjection to Clspist (London, I657), p. 89 .

9 Beleever, p. 243.

10 Beleever, ?. 191 . 
assist with the persuasion. We can see why Olsson concludes that according to shepard's teachings, ".". man actually comes to faith on being persuaded to belief."II Hooker's teaching, as we have seen, reaches much the same point, the difference being that Hooker usually couched his teachings in less bald language than did shepard.

Hooker has been said to differ from all other Puritan preachers of eurly lvew Ingland in that he alone preached conversion to the unregenerate loutside the covenant. 12 By this interpretation all others preached conversion only to thoṣe within: "hypocrites who had been admitted to [church] membership by mistake, and the children of the godly who enjoyed nembership though not converted."I3 But what this historian says of Hooker applies equally to Shepard: he was

11 "Writings of Shepard," pp. 60-61. Shepard is the author of a very interesting work entitled "A 'lreatise of Ineffectual Hearing the vord; How we may know whether we have heard the same effectually: And by what means it mar become effectuall unto us" (in subjection to Christ). Herein Shepard considers the relationship of two classes of people to the hearing of the word. The unregenerate he can only advise to come to the means, to hear seprinors. But the regenerate may find that when they hoar the wora preached it cones to then onlyr as tile extexnal word. Lo tizen Shepard prescribes four methods by which they can cone tho hear, in the external word, the intornal vord speaking to them individually. One of tire uethods is to "Draw near to God in the word, by looking on it as God sprakiff bo tiree"--subjection, p. 107. Shepard's advice seens to anount to tisis if you ternally, you will in fact so' hear it.

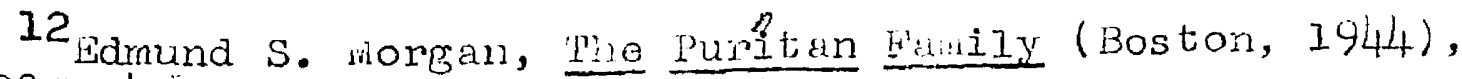
pp. $98-104$.

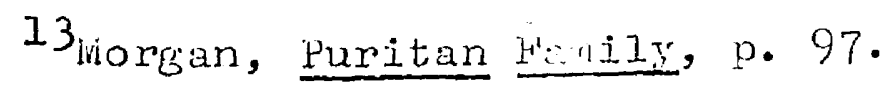


"an example of evangelical zeal . . a man who spoke his words to sinners rather than saints."14 Here is shepard's usual approach:

\begin{abstract}
- - you young nen heare this, though you have spent the flower of your yeares in vanity, madnesse, \& filthy lusts, yet the Lord calls you up to him; you old men growne gray headed in wickednesse, though it be the jast hour of the day in your Iife, yet behold the lord will hire you, sils cals you to come in.... .15

God this day calleth you, it may be he will never call more; ilow many hath the Lord struck with death and sicknesse? And howe soone it may be any of your turnes; I know not; sicknesse is an unfit time to get Christ, and to make peece with God. If you stand still you dic; therefore turne from all your sin, and come in and lay hold by faith on the promise, that so ye may live, and this that I have spoken unto you may not be in vain. 16
\end{abstract}

An essential difrerence betweon ilooker and shepard can be seen by comparing these passages with those of hiooker which are likewise exnortatory. Shepara is much more direct and relies on his eloquence rather tiran on subtle techniques such as those in Hooker's writings. Ihus we find much more heli-fire preaching in Shepard's writings than in liooker's, and much more preaching of the joys of heaven. Hooker indeed makes use of eloquence, but it would be difficult to

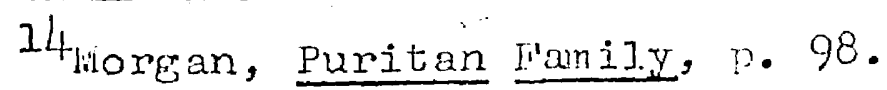

15 Beleever, 0. 246.

16"mhe sants Jewcl," in Convert, pr. 226-227. Although liorgan qutes pascaves Wibrein John Cotton cyoids actdressing those outside tio covenant, in wany works he also preaches regeneration to all. his hearces. see below. 
find anything in Hooker's writings to compare with the folIowing passage by Shepard:

- - desire and pray, that heaven and earth shake till thou hast worn thy tongue to the stumps, endeavor as much as thou canst, and others commend thee for a diligent christian; mourn in some wildernesse till dooms day; dig thy grave there with thy nayls, weep buckets full of hourly tears, till thou canst weep no more, fast and pray till thy skinne and bones cleave together; promise and purpose with full resolution, to be better; nay, reform thy head, heart, life, and tongue, and some, nay all sinnes; live like an Angel, shine like a Sun, walk up and down the world like a distressed pilgrim, going to another countrey, so that all Ciristians cominend and admire thee; die ten thousand deaths, lie at the fireback in hell so many milizions of years, as there be piles of grasse on the earth, or sands upon the Sea shore, or starres in heaven, or motes in the Sun; I tell thee, not one sparke of Gods wrath against thy sinne shall be, can be quenched by all these duties, nor by any of these sorrowes, or tears; for, these are not the bloud of Christ. 17

Calvin would have called this statement blasphemous, for to him no one can perform these duties unless he is of the. elect, although the reprobate might, by benefit of cormon grace, lead a decent Iife. Indeed, according to calvin no man can Iive Iike an angeI; certainly a reprobate cannot. But Shepard's purpose is clear, and his nethod is as direct as possible. For litil convorsion is the only neans of winning God's favor.

Shepard's teachings difler most from liooker's on the matter of preparation. jooker regarded ils audience as being in one of two classon: either tiner regarded t: anselvos

17 Convert, pp. $81-82$. 
as converted, in which case he exhorted them to test themselves; or they were unconverted, in which case he would exhort them to use the means by which they might be saved and then prescribe' what they must do. But, as 0lsson has shown, Shepard considered each man to be at a certain stage in a continuum, at one end of which is salvation and at the other end damnation. Bach person who is to be saved needs to cover the same ground if he is to reach salvation. 18 one step will not suffice for salvation, which is a much more complicated process in shepard's teaching than in Hooker's. It is indeed true that according to Hooker's theory ". . the Lord requires and works in those he will draw to Christ, Contrition and Fluiliation."19 But in his practice, as we have seen, Hoolror teacies that if man completes the contrition process he is saved. irot so with ghopard. For him there are four stops: conviction, compunction, huniliation, and faiti. 20 wach is necessary and one depends upon the other.21 According to Shepard,". . the Lord Jesus in the day of his power, saves us out of our wretched cstate; by so much conviction as begets, compunction; so mucil compunction,

1801 sson, "uritings of silepara," pp. $69-105$.

19ine Application of Redenption: The inith and Tenth Books (Lonaon, 1657 ), p. I5.

20 Beleever, pP. 3-1.

2 In shepard's teacing bilo rour sbops ape described as "aistinctly set forti.,. - In tis at os" virists power

- . "-Beleover, p. !. 
as brings in humiliation; so much humiliation, as makes us come to Christ by Faith." 22

Two aspects of Shepard's technique which we have thus far considered may be elucidated further by an examination of Shepard's teaching regarding the first step he sees in conversion: conviction. By examining, the teaching, we shall be able to see how he envisions the function of the Deity in conversion and also how he subdivides even the subdivisions of the redemptive process.

In Shenard's view of conviction, tire first step is seeing sin: what Hooker calls "a true sight of sin." A sight of $\sin$ is necessary because" . . no inan can feel sin, unIesse he doth first see it, what the eye sees not, the heart rues not. . Iet a poore sinner lye under the greatest guilt, the sorest wrath of God, it will never trouble him untill he see it and be convicted of it."23 In order to bring to his hearers such a sight of sin,

- - the winister preacheth arainst one sin, it may be whoredom, iEnorance, contempt of the Gospel, neElect of secret duties, Iying, sabbath-breaking, ci c. 'This is thy case saith the spirit unto the soule, remember the tine, the place, the persors with whom thou then lived in this sinfull condition; and now a. man begins to roe alone, 2 to linink of all his, former courses how exceedins, evil they have been?. .24

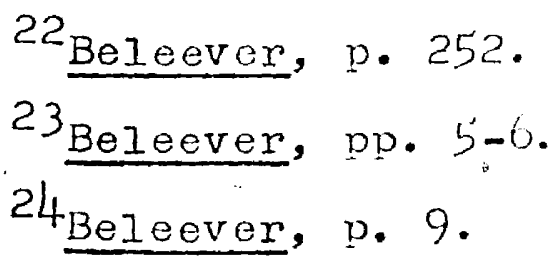


In addition, God may, by means of his preachers,

- - let a man see his blindnesse, his extreame hardnesse of heart, his weaknesse, his wilfulness, his heartlesnesse; he cannot pray, or looke up to God, and this may first convince him; or that all that he doth is sinful, being out of Christ. 25

The first step has been completed when the sinner sees his sins. But next he must be convinced, again through preaching, of the great evil of his sins. This work must be done by the Holy spirit, for natural man, though he may see his sins, cannot recognize the great evil of them. Only the supernatural power which acts through preaching can do the work. 26

Next, the Spirit convinces the sinner that evils follow sin. Here shepara emphasizes vigorously that a sinful soul "must dye, and that eternally."27 He preached hell-fire more frequently than Hooker, perhaps because he recognized that this kind of preaching gave him an opportunity to use his powerful rhetoric. He speaks of "the bottomless pit" and "the endlesse woes and everlasting fires,"28 and warns that Satan's most useful trick is to persuade men that they are not liable to etemal punisinient.

Having convinced the reason, God and the preacher must

25 Bëleever, p. il.

26 Beleever, p. 13.

27 Beleever, p. 14.

28 Beleever, p. 16 . 
now convince the heart of the sinner. Rational conviction of $\sin$ is not enough; "spirituall conviction" is required.29 Shepard defines the point when contrition has been achieved: "all the Electl must have "So much conviction of sin as may bring in and work compunction for sin, so much sight of sin as may bring in sense of $\sin$. . " 30 Conviction in itself will do no good unless it leads to compunction, which affects the will: ". . a bare conviction of sin doth but light the candle to see sin; compunction birns the fingers; and that only makes him dread the fire."3I In shepard's works even more than in Hooker's, one can see that the conversion process, if followed by a man according to the rigorous prescription of the preacher, would result in a new psychologjcal point of view by wich a man might very well have a hatred of sin-or at least a hatred of those sins which he had been so carefully taught to hate. One cari see psychological resemblances between the puritan's prescribed course to conversion and methods of indoctrination used by inodern totalitarian stater. Shepard's ain was to make sin so utterly repulsive and panful that one would never go buck to his old ways.

In Shepard's description of the conversion process one

29 Beleever, p. 20.

30 Beleever, n. 2!:

$3 I_{\text {Belcover, }}$ n. 12 . 
can observe more clearly than in Hooker's writings the role of the Holy Ghost in regeneration. His role is to make the sinner see that the preacher's words apply to him. In a sense the Holy Ghost can be said to be the variable in the minister's "experimential" preaching. If the sinner is moved by what the preacher says, it is because of the spirit. If the sinner is unioved, the theological explanation is that the Holy Girost is not working in his heart. But preachers must hold man responsible nevertheless, contending that the fault is in man, who can perhays thereby be persuaded tinat he is resisting Grace. If he conceives of himself as resigting. Grace, tiren perhaps he will be persuaded to accept grace. In this case the Holy Ghost can be considered to have worked the persunsion, thourh of course through His instrunent, the preacher. Again we can soe how it can be said that the preacher "rationalizes" frace.

Iike Hooker, shepard had to take into account that the concept of predestinntion :1ay be a deterrent to man's ef'forts to be saved. One of shepard's teciniques for contending with predestingtion might bo labelled argunent by false analogy. Hoolier does not seen to have used bino sane argument. "It is true," declares bistyisu, "God hath el ected but few: so thou must in this case verture and try, as inany men amongst us do nov, who henring of one good living ral len [vacant], twenty then will ro ind seels rop it, alt odil thoy 
know only one shall have it." 32 Either the elect manifest themselves by their efforts--in which case all tuenty in Shepard's analogy are elected-or election does not depend on willing and running but on God, Who shows mercy. In either case shepard's parallel is not a true one, but we can see that from inis point of view it would have been valid if it had persuaded some people to take a chance and use the means.

Two minor aspects of Shepard's thought are very similar to Hooker's. First, Shepard areues that man's day of salvation is now: "Thy day of grace, thy day of means, thy day of Iife, thy day of Gods striving with thee, and stirring of thee, still lasts."133 shepard does not cortend, as Hooker does, that some may find they have decided too late to respond, for, having resisted grace before, they will find that God is not now' willing for thein to be saved. Second, Shepard contends for a certain very small degree of voluntarism, much as does Hooker. If a person says, "I feare I shall never do this [part frol iny sins]," Shepard answers, "But art thou willing that Christ should make thee willing, and pitch thee upon a pronise, and siould hold thee tinere? If thou canst find these things, then comfort thy self, for thou hast right unto Gods promises." 34 perinays shepard is

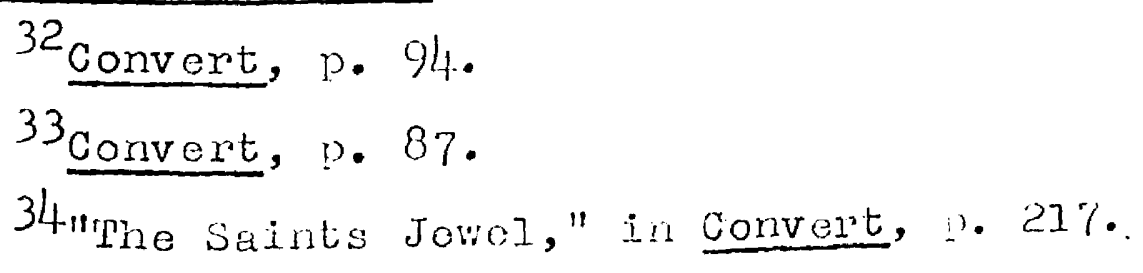


merely arguins that willingness to be saved is a sign of election, but it seems at least possible that, like Hooker, he is reducing the quantity of effort required of man to a bare minimum, because of the influence of the strict theology of his day.

.. One finds fairly frequent references to the covenant of grace in Shepard's works, bui, Iike Hooker, Shepard appears to have relied seldom on the covenant idea as a preaching technique. However, in two places he uses the concept, though in a way very different from Hooker's rare use of it, and also very different from the later covenant theologiansi use as described by Perry Willex. Shepard contends that inany of his hearers have the good f'ortune to be within the covenant of grace but warns,

Seeing God hath rromised absolutely such good things in the second Covenant, lut hath not set downe the time when or how much grace he will give; and seeing only he can helpe, thererore looke up, and wait upon God in the use of all. knowne meanes, untill he makes good what he heth promised to do, and performe, and worlie rop you. 35

Here Shepard contends tiat an musi use tile uleans so that God will give the sinner the grace that is due hin. The effect is to cancel out any satisfuction to be Eained from the covenant arrangement and, on tio otior hand, to encourage men to think that if thoy use tho means thoy will be

${ }^{35}$ Certain Select Cases iesolved (London, 2658), p. 36. 
practically assured of salvation.

Elsewhere Shepard discourses on the covenant arrangement and concludes by questioning,

- - is this not matter of great consolation to all those who reel theinselves utterly unable to beleeve? you think the Lord will Eive peace and pardon, life and mercy, if I could beleeve; Oh consider the Lord hath undertaken in the Covenant of Grace bo worke in all his the condition of the Covenant, as well as to

Shepard does not conclude fror such a situation that men should thcrefore leave to Goi the task of inaline them believe. By a very nice lisplay of logic he instead questions, "But why hath the Lord made tilce feel thy inability to beleeve?" shepard's answer is tilat God wi shes for man to "ask and seeke" for belief. If men suor long and hard enough, apparently they will prepare themselves for God's eranting of their request. 37 since God will make his elect Delieve, man's obligotion is, in bilepuris view, to seek for belief.

In looking at sinpiad's toachinge ve have considered four inain asircets, which we havelonpured witil iooker's teacinings and tochniquos: mormation for salvition, theory of preaching, rhetoric, and covenant theoloes; Altiough on

$$
\begin{aligned}
& \text { 36 Be.lecrer, pp. IуI-ISz. } \\
& 37 \text { ielecvur, : } 152
\end{aligned}
$$


some other matters of importance Hooker's and shepard's methods and teachings are.similar, on each of these points there are important differences. In his teaching on preparation, Shepard insists on the necessity of passing through four distinct and different phases, each of which offers serious difficulties. Hooker teaches only two pirases, and each Ieads separately to conversion, though tire two are different.s In his theory of preaching, sinepard is as explicit as Hooker concerning the existence of an internal and an external word, and yet at the same time for persuasive pur- . poses he confuses the two even more completely than Hooker. In his use of rhetoric, a matter which we have exanined only indirectly with respect to Hooker, Siberard was inclined to rely on emotional exhortations and denunciations. 38 Hooker, on the other hand, though an able rhetorician, preferred somewhat more impersonal methods: careful analyses of the "shifts" and devicos by which men avoid taking to hoart tice teachings of the preacher. neferences to tire covenant of. grace are more cormon in sizpurd's wribings tran in Hooker's, and Shepard does indced use tile covenant scilene as a device for assigning man more responsibilitr, as Hooker does not.

38 one more sample of sherard's colorful phetoric may well be quotod here. sccorting to siloma, vinist addresses sinful men as follows: "I llave lound tin world berole I came, a world of curses, bryers, thomes, and thisles; but now I will have you know I havo purchasca a jirden, ind bave brought tise blessing of crod into it, I irive nfde tre.cursed world a garaen, and have enriched it with conforts for your sakes, I am cone into iny rimaen. - . "--oonvort, po. 229230. 
Shepard is teachings and techniques are thus rather distinct from Hooker's.

\section{John Cotton (1585-1652)}

The writings of John Gotton differ greatly from the works of Hooker. Although Cotton was a greater figure in his time in both old and New England, the modern reader is likely to find his writings flat and colorless compared with Hooker's or Shepard's, and his teachings are quite different from Hooker's.

In England Cotton had been a famous preacher before and after his conversion to Puritanism and had been responsible for the conversion of John Preston. 39 llow thglanders came to regard him as their greatest divine.40 His voluminous and learned works are more varied in nature than Hooker's or Shepard's, many of them being controversial works and biblical commentaries. But although his ow conversion was dramatic and his converting of others notable, most of Cotton's published sermons do not deal prinarily with conversion. "e do not find in a Cotton bibliograving any such titles as the Unbeleevers Preparing for Christ or the Sincere Convert. Cotton was imuch closer to calvin in his preachine practice

$39_{\text {inather, lisarnalia, }}$ I, $233-235$.

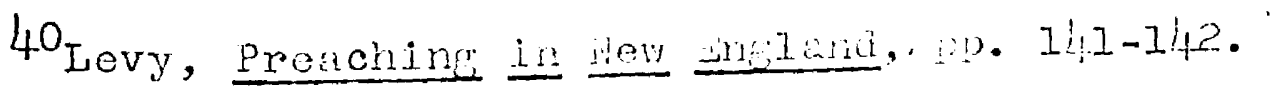


and wrote instead such works as The Way of Life, which is more concerned with Christian living after conversion than with the process'itself.

Cotton's grandson Cotton liather tells us that ". . In his later days he indulged in nocturnal stuaies more than formerly," and being asked why this should be so, "he pleasantly replied, Because I love to sweeten my mouth with a piece of Calvin before I co to slcep."lt Considerine this fact, one may be surprised to find very. few references in Cotton's sermons to predestinetion. One of cotton's rare uses of the doctrine of predestination is very different from Calvin's ordinary use. Calvin erinasizes God's mercy in electine-before all tine--some men for salvition when all deserve to be damed, whereas cotion reproves those who excuse thejir sins on the prouncis of predestination, by declaring, ". - Iittle do such goules hnor what wickednesse hath been in their [the reprobates'] hearts, that hath givon God just cause to givo tinem up to such vile affects . . ." God, cotton goes on to say, dains nen only after they "have filled themselvos "With filtinosse."ll2 Calvin likewise taught that God hid just occrsion to give rejrobates up to the rilthiness of ain, but ho al:o insister that ". . the sane wickedness woula possons tire minas of the jormen lthe

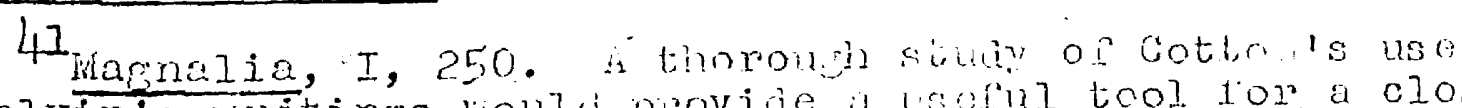

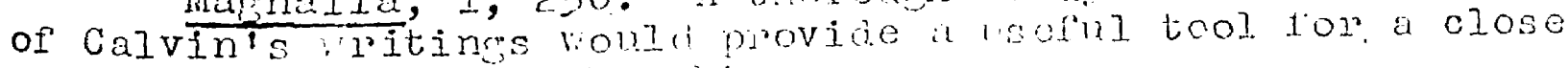
analysis of Cottonis bhomit.

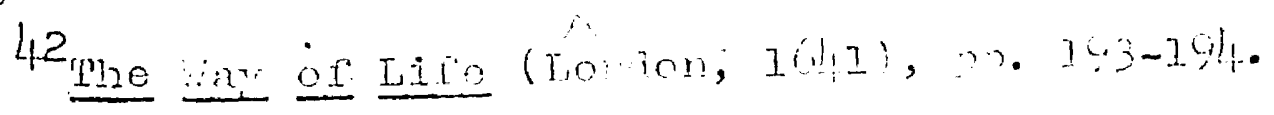


elect], did not God in his eoodness correct it." 43

In order to sèe how Cotton treated conversion, let us begin with the third sernon of Gods luercie wixed with his Iustice (London, I64.I), more completely a conversion sermon than most of Cotton's works. Here he argues that God will treat sinners as briars and thorns in a gurden. But, he contends, men can make peace with God and thereby avoid punishment. To do this they should talie "hold of his [God's] strength," which will give then the power to resist sin. As Cotton describes the process, obtaining God's strength is neither a difficult process nor one in wich only a few men can participate; rather, the process seoms easy and attractive. ben shoula cast away their sins, stor trusting in themselves, believe in God's nercy, and romind God of his promises in their rrayerd (pages 68-71). Whese are of course the same kind. of stens which Hookex prescribes, but Cotton proposes them as easy suggestions; Hooker, as extremely difficult, sometines impossible, requirenents.

43 Institutes, III, $24, x i i$. Compare III, 23, ix: "The reprobatewould excuse their sins by alleginc that they are unable to escape the necessity of siming, especially because a necessity of this nature is laid upon thein by the ordination of God. ie deny thit they can be thus validly excused, since the ordination of od; by winch they complain that they are doomed to destruction, is consistent with equity,--an equity, inded, unknown to us, but most certain. Hence wo conclude, that every ovil wich they bear is inflicted by the most just judrment of Gol. lext vin have shown that they act proposilurously wien, in seekin bine oriEIn of their condemation, they tum theip viow to we hidden recesses of the divine counsel, ari i.ink at the corruption of nature, which is bie true souro." 
Cotton says nothing in this sermon concerning election or spiritual inability.

Elsewhere Cotton demands less humiliation than Hooker prescribes. Cotton seems to have been almost af raid that some of his hearers might try to become too humble. "If I be so farre humbled, as to corne off with self-loathing; that my heart is broken because. I have broken Gods heart, this is himliziation enough to find pardon." 44 by modern standards Cotton demanded much; but compared to Hooker's, his requirements were decidedly lax. Accordins to Hooker, the soul achieves true humiliation only' wiren it can declare, "Oh. . . it is fit that God should glorifie hincelfe though I be damned forever, for I deserve the worst... . 145 He had also insisted that'". - you had need pray for the repentance of your repentance; and to begre the pardon of all your prayers . . . 146

From these discussions one can readily see that cotton believed in a forin of prepiration, just as shepard and Hooker did. The nost inportant distinction between the teachings of Hooker and sheyerd on the one hand and cotton on the other is not in the realm of contrition and huniliation. It concerns those steps wich Hooker urges on the

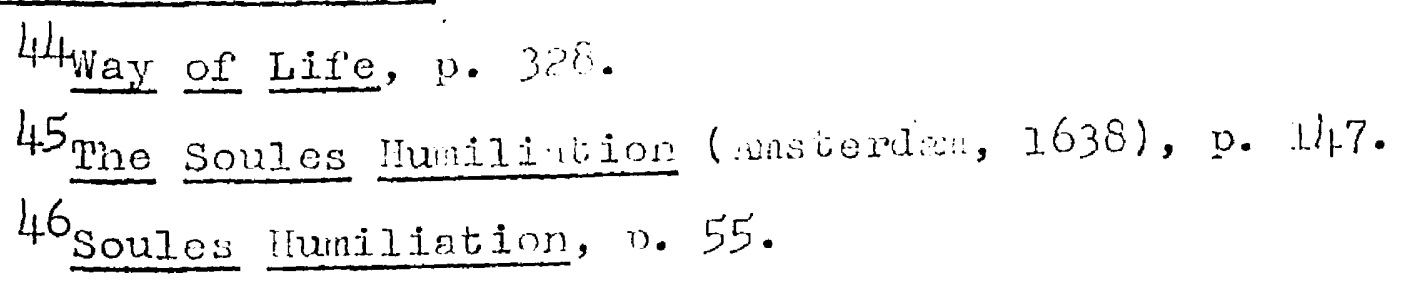


basis of common grace--hearing sermons, reading books, waiting upon God in the means. 47 Because the gap between total depravity and sanctification is so rreat, Cotton believes that man could not, by himself, prepare for salvation: "for our first union [with Christ] there are no steps to the Altar. "48. On the other hand, Cotton agrees with Hooker that God effects contrition in the hearts of those whom He will save, as a means of preparing ther for salvation. 49 cotton uses again the image of the marriage ceremony: "inow because God intends a marriage Covenant betwixt Christ and our

47 Perry lililer considers thit Bhena ed taught much the sane doctrine of preparation as cilid iookcr. see lile Hew england wind: From Colony to Province (Canbidge, Thiss., 1953), pp. 64-65, hereafter cited as jolony to érovince. 48 ine ivew Covenant (Lonion, Iús!), p. 54. 49 The orthodox doctrine, as found ir Ursinus, is as follows: "If they insist that the $\mathrm{H}$. Spirit [sic] is not offectual in those who do not hear the word and persevere in their sins against conscience, that therefore for hearing the word and dropoing sins it is necessary ior then, being unconverted, to nrepuro tienselves for convexsion--we reply that tinis may be conceded as : whole, but that tine two lfollowing points do not follow. Hirst: that the works in question are pleasing, to God. Althousil lioki lises not only tinese but also other wolks of tile non-leborn (like acknowledgemert; of sins and fears of conscience, as:ociation with the godly who attract t:e!t to goil. iness or with the ungodly who deter them from ungodiness, their om crines and punishments), to prepare men tor corversion and salvation, nevertheless so far as the men tirels lives ure concemed, ill these things are prior to conversion. isecond: tiat such morally good works are due by tile non-rebom atinout divine providence and sur estion ooverning tines uinis, sc that at last they might be catherod into tine ciuncil. Evon in bile non-reborn notiling good cin be rone, wilicil Gou does lot effect so far as it is food."--ioci neolosici (1562), quoted

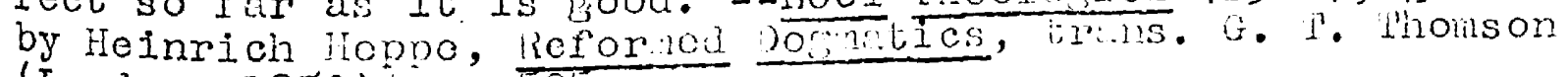
(London, 1950), p. 525 . 
soules, in first conversion, he will therefore have sin first mortified in us, our first husband must ly a bleeding his last blood berore we can be married to christ." 50

Like Hooker, Cotton holds that God pricks the hearts of those whom He will. save and thereby makes them contrite; this is "the first work of saving and living grace." 51 Cotton is a good deel nore' subtle than jooker in his method of getting his hearers to achieve contrition-more subtle at least in his sermon on acts ii. 37, the sane text wich Hooker used for lile boules preparition. Hooker's inetilod is to prescribe the sieps which one should take to become contrite. Cotton instead declares first tiat if one does not find that his heart has been vricked, he should remain discontented with his spiritual state until it is pricked. Phen, instead of setting forth directions, Cotton presents a full description of wilut one experiences when he has a pricked heart. It is, for instance, ". . Eood evidenco of an heart pricked and sprinkled with a saving and kindly sense of sin, wisen we iven to love and respect tiose

\footnotetext{
50 Way of Life, p. 130. The sinilariby of cotton's viow

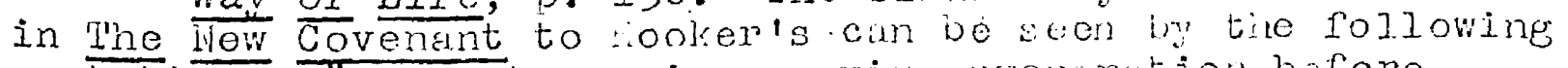
quotations: $\pi . \cdot$ there is a saving preparation before $\dot{0} \cdot$ the manifestations of our oratins urion witis hin [Ciristj; but for our first urion, there wre no steps to the hitar - . But Christ notir prepare his pabornacle for himselfe to dweil in."-lvew coverant, pr. $53-54$. "The soule must bo broken and humbled beforetie jora jonls Gindet can or will dwell therein, and befor faith con we wroult terein." --Hooker, the Soules Inolantition (Iomion, 1637), • 3 . $5 I_{\text {Way }}$ of Iife, D. 126 .
} 
Christians, whom we have despised, yea even such as have wounded us [preachers do the wounding?], and are willing to enquire of them the way to salvation, and to resigne up'our hearts to bee directed by them."52 These are surely directions--in all but form.

Seldom does cotton resort to downright directions. He is more likely to set forth his exhortations indirectly, in this fashion: "The pricking of the heart is wrought by hearing the word of God, applied to the convincing of our soules, both of our particular sins, and of the greatnesse and goodnesse of the God, apgainst whom we have committed them."53 When he does direct his hearers to take specific steps, they are much the same as what Hooker prescribed. Here Cotton sets forth, briefly, four steps: (I) ". . yeeld up your hearts to God... ." (2) ". . apply tire wora unto your hearts. . ." (3) Ask Goa for brace. (4) seék for spiritual knowledge. 54

Another serion of Cotton's may make even clearer the similarity of Cotton's and Hooker's yiews. It is "godly sorrow, by which men are brought to Christ," Cotton declares;". . the spirit of crace.. opens their ltive elect's] eyes to see, that anl their sinnes $\cdot$. have

$52_{\text {way }}$ of Life; p. 136. 53 way of Life, p. I6z. 54 ivay of Life, pp. 184-1é. 
reflected on Christ." 55 such being the situation--and Cotton is here less subtle than usual--if man wants to be saved, he must get this godly sorrow (which is a work of the Spirit!). Cotton then directs, "If . . thou wouldest bring thy heart to unfaining godly sorrow, then pile thy sins as a sharp arrovi shot at Christ, else they will not kindly wound thee."156 Furtiex, in order that there may be no question concerning how one nay reach this godly-sorrow for sins against Christ, Cotton sets down at some length the various ways by which nan's sins can be said to be against Christ. 57 Presurnably, if one consiaers tirese ways, he may be brought to true contrition. Cotton's tecinique differs from Hooker's, but his concept of preperation is basically the same. 58

A more extended example of Cotton's subtle technique can be found in whe iay of Life. Cotton questions, "But how shall I get a spirit of Grace?" and answers,

First, if God be pleased to open thine eyes to see what a dry soule thou hast, and thou art sensible of the drynesse of thine own heart, wantine sap and mojsture, and ant therefore atinirst for want of Grace, then it is very hopeful bod will eive thee a

55 Way of Life, o. 31. 56 Way of Life, p. 4 . 57 ivay of Life, pre 31-36.

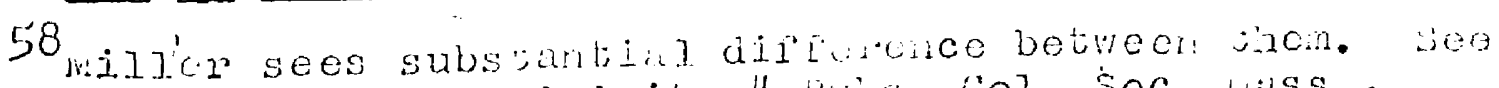
"The jarrow of turitan jivinity" Transactions, $1933-1,3, \operatorname{LXXII}(193,1,20 \%$ 
spirit of Grace. Esay 44. 3. To whom will God Give the spirit of Grace? to those that are dry, and thirsty, that feele themselves athirst for want of Grace. Though thou canst not yet call God Father, nor look at him as thy friend, yet if thou hast but a thirsty soule, and longest ror srace, under sense of thine owne droughtinesse, then God will not deny the 5 foly Ghost to them that ask him, Luke, 11. 9.

In answer to the question, How can one get a spirit of crace? Cotton declaros that a thirsty soul is a sigr of spiritual health. 60 clearly he is ureing men to get "dry soules" just as Hooker urged rien to meditate on their sins. Hooker and cotton vore attennting to achieve in their hearers the same spiritual state, though their tochniaues are very different.

In anotrer work Cotton states injs viars on preaching", which are, at leart in this passare, uncin nore orthodox tran Shepard's confusion of tine external and internal words. Cotton exhorts his hearers to "tal:e hold of christ" and then considers this objection:

But what shall. I doo to get hin? how may I come to "have him? you said, we cannot reach Christ by nature, and though we could we will not; are not exhortations then in vaine?

Cotton answors with considoper fortipightness:

59 Vay of Life, p. II. Combure the passaces Irom Calvin

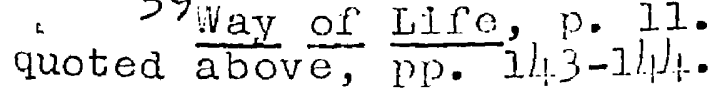

60 otier signs which, cortion cites are ailicont searing of semons and tumine froil wickodners-.-. 
No they are not in vaine. . . Though we be of" that naturall sinfull distemper, that we would have all things but christ, and let him goe, yet while we are thus sneaking to you, God many times conveyes such a spirit of grace unto us, as gives us power to receive Christ . . those that sial be saved, we speake not in vaine to them, the worde that we speake conveyes spirit and Iife unto them, then they begin to receive life in him, and are glad that they may finde christ, and for other men, it leaves them without excuse, if they do not use the meanes, God appoints theri to use.61

- These could almost be Celvin's words.62 Iooker inf similar situations was much more direct. Whereas Cotton here only indirectly sugerests that men should use the incans, Hooker argues simply thet, although men cannot make the word effective, they can do far more than they are now doing towards achieving salvation. 63

But in spite of this strictly orthodox statement, in Gods liercie ilixed with his Iustice otton preaches, in exactly the sane pashion as Hooker and shepard, that man can still repent oven tibugh he may have resisted frace before.

- . Let no man be discouraged, what if thou hast staied tiree yees, wist ir fourty, what if a hundred and twenty yeers, yet all this tine God hath stared; let it now now hinder the from turning to God. . . but as lone as God waites, and especially so long as hee knocks, there is some hope, if thou wilt, but open tinee in hope. (page 18)

174 .

${ }^{61}$ Christ the Fountaineof Life (London, 1651), pp. 173-

62 see above, p1. 62-63.

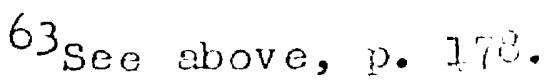


If God has knocked for a hundred and twenty years, He has knocked without a spirit of grace, or Cotton, like Shepard and Hooker, is inconsistent.

Again like Hooker and Shepard, Cotton sometimes considers God's internal word as merely the offer of grace rather than the conveying of it; the offer takes place whenever a semon is preached, pather than at one precise time, when those to be convicted "receive Iife" in Christ:

How shall I discerne the signes of the tines of the visitation of my owne soule, for crace offered; that this is the time that God of fers grace to my heart, that I doe not out-set my tine: irow shall. I know it? 64 .

Cotton answers:

Christ hinselfe followes close the pure ministration of his Gospell, and that's the day of salvation .

The day of salvation, therefore, is tody, for now we are hearing the gospel preached purely.

We have seen that in Cotton's prosentation the conversion process seens much less arduous than in Hooker's

64 Gods mercie, p. 119.

65 Gods mercie, pp. 120-121. Cotton's noxt question is,

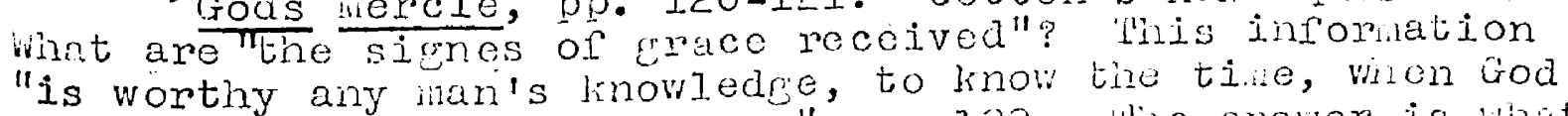
hath pisen to his heant.." "-n. 12?. Lire answor is what we might expect iron wit we kive is wer of cotton!s tieology:

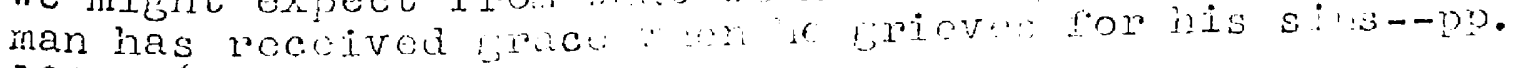
$122-126$. 
preaching, or in shepard's. Another interesting description, from the ivew Covenant, presents auditional details. Cotton's purpose in the following passage is not to convert his hearers but to describe carefully God's nethod.

You shal find that the Lord usetis to convey himselfe unto the soule in some woxd of Promise of the Gospel that sheweth unto the soule the riches of the grace of God in Jesus Christ; somethine or other is declared of christ. 'Phis word beirg taugint. in the publick uinistry of the word, or brought to renembrance in sone spirituall duty, as Prayer, or Conference, or the like, (for I will not linit the rioly One of Israel) yet usually it is done in the rinistry of the Gospel; and though the Lord doth linit us to attend upon the meanes wich ile usually worlieth by; but what soever the way be, this is tile inaner of Gods worling, he dotin univorsally come unto the soule in sone word or other of his grace... . In some word of his grace he comneth and putteth life into the soule, and maketh it somwhat quiet, and causeth it to seethat there is hope for Israel, and the Lord is ablo, and there is riches chough in Christ to savo ne. By sucin kind of work it is that the Lord bringeth the soule of inis servants effectually to Cinist... (pacos 188-189)

This description is very different fron Lookch's ciescriptions of the process in bint there is nothing at all painful to be endured by the convint; lio now not be willing to be damed, for instunce. line doscripition quoter above appeurs toltypify Cotton's view of the conversion process.

Only eight very smal octuro pages later, however, Cotton describos the conversion process feen. lluis second description, bhow in harly. as eloom as comparable doscriptions by rooler and monru, is iffijente to recornile with Cotton's customry view. We pasare in inportan enough to 
warrant quoting in its entirety. According to Cotton, God

- will rend, as it were the caule from the heart, I mean he will pluck away all the confidence you have built upon; a as [as a] man would rend the intralls of a beast froin him, so the Lord will bring you to a flat denial of your selves, and that you have neither cood. will nor deed, as of your selves: And, you will find, you know not what God will doe: with you, but this you know, that whatsoever he doth he is most righteous. When the Spirit of God cometh as a Cornforter, he will. in this manner convince the soul of a man that he hath heretofore hung upon his reformations for hope s confort, but now he is brought plainly to see and flatiy to deny, that he hath so much as one drop of tire fatnes of the true Olive in him, when he most trusted unto his excellencies. How a man being thus $f a r$ brought on, doth not only deny himselfe in his judgement, but in his will, and is peady to say as bavid sometines did, If the Lord say he hath no pleasure in me, here I am, Iet hin doe unto me as seeneth him good. The Lord is righteous in ali that coneth upon me: this onely the soul hith for his supropt in such a case, the Lord is able to doe all for no bhat I stand in need of: If he show he no nercy, he is just, if he be Eracious, I shall live to praise hin. Wow when a mans will is thus subdued, that he hath no will of his own to be cuided by, but onely the will of God; this is true brokennesse of heart, when not onely the judgenent, but the heart and will is broken.. - Then conetir the Holy firost in sone declaration of Gods free.love, and taketh possession of the heart, and tion the soule beginreth to pant after Jesus Cinrist, and nothing in heavon but him nor in the iarth besides ilin. Tile soule beginneth to put forth it selfe towards the Lord Jesus but the lioly Ghost hiving; taken possession before, helpeth our infirmities, Rom. 8. 26, 27 . He al one must help us, and no otner. (naves 197-198)

Three points deserve abtention isere. lirst, the process is described as very painful; the inage of rencing the entrails

from an animal is a strons and mplodsant one. wecond,

Cotton at least inplies thä nan roacisu tire poirt of will-

ing to be dimmed for cod's colory, jus as ioolies taught. 
Third, the process, though grievous, does not appear as strenuous as in the teachings of shepard and Hooker: it $\rightarrow$ seems abbreviated. How the first two of these points can be reconciled with Cotton's teachings elsewhere is far from clear.

Although, as miller has shown, Cotton was in part responsible for the outbreal of Antinomimistin in wew ingland in the late $1630 \mathrm{~s}, 66$ Cotton insisted on tire necessity of good living after conversion. As we have seen, ilooker sought to bring about the sanctification of the converts in his charge by exhortine; them to test tilenselvos continually. Cotton for the sane purpose taught tint ". . many temporall blessings wee nay get by Gods accentance of our Evangelicall obedience . . ."67 rhe elect will be rewarded in this life for the proper use of the mace given them. "The Redeemed of the ford find favour, for as, they are redeened from the bondrec of sin, so thoy are now accepted in the sight of God, as chiliron aro accertable lo tinoir parents,

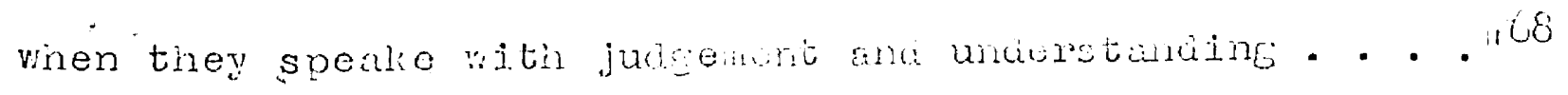
Iot only do the elect rind fuvor with God won they act with

66 Coluny to province, $58-64$.

67 Way of Life, p. 230. Cotton did indeod use tie

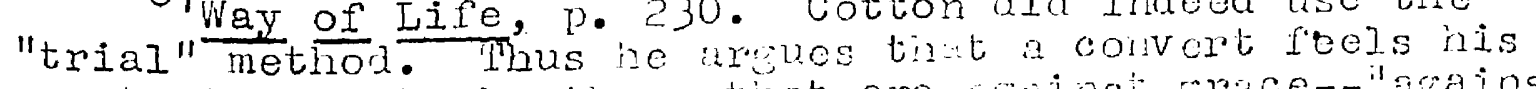
greatest sins to bo those that are aginst erace--iagainst

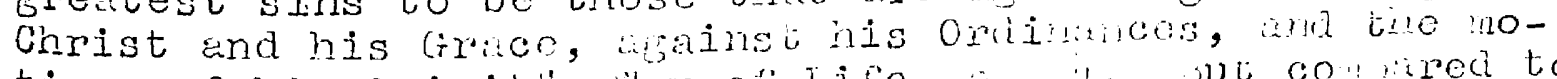

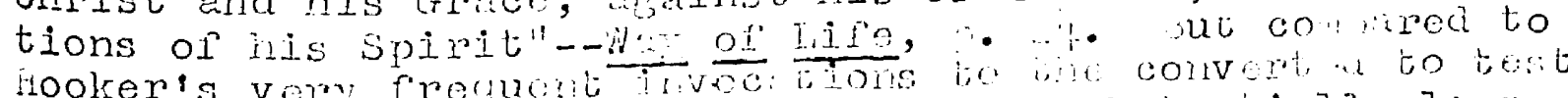

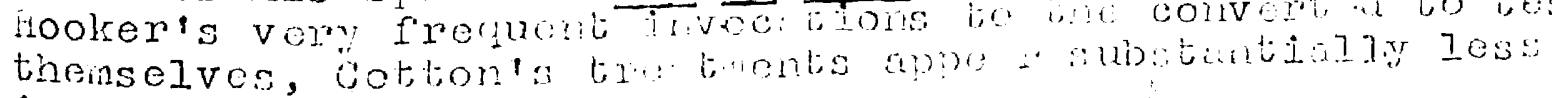
important.

$$
68 \text { ivay of Ine, n. T. }
$$


judginent and understanding, but also they are punished in this world for violations of God's laws. "There is none under a Covenant of Grace that dare allow himselfe any sin, for if a man should negligently commit any sin the Lord will schoole him thoroughly, and malse him sauly to apprehend how unworthily he hath made bold to abuse $\varepsilon$ imbeazle the treasury of tine errace of cod." 69

This reference to the covenant or Erace, alone with other discussions in cotton's watings, provides us with abundant evidence that he was fully faniliar with covenant theology. 70 But, like jooker, Cotton does not seen to have rade much use of tile covenant idea as a tociniulue in preaching conversion; at least in the sermons which have been read in the preparation of this study, Cotton relied, as we have seen, on the sacranental theory of honiletics, in much the same way as Hookel did. One student of Cotton has declared that his teaching differed froil Cajvin's in that, though "it is still God who proviacs salvution to sinful rnen, yet salvation is not imposea but is based on crod's covenant with men." 71 It is not quite accurute to imply that in Calvin's viow God imposed salvation, but it is truo that in is

\section{${ }^{69}$ Covenant, pp. $1.34-135$}

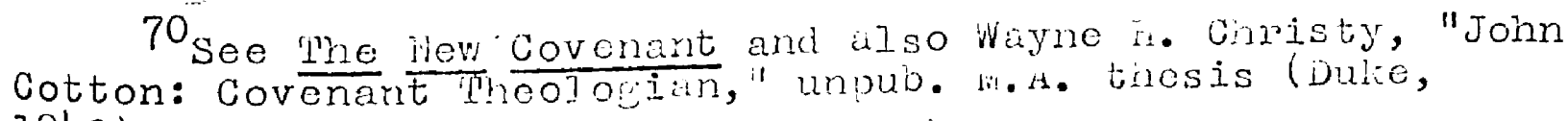
1942).

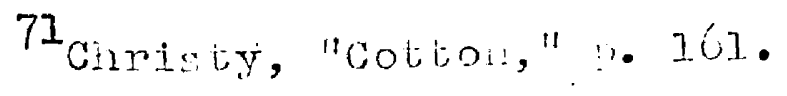


sermons Cotton, being more soteriological than Calvin, uses different techniques. 72 He repeatedly teaches, however, that men do not wish salvation. For example, Cotton argues, ". - it is an usuall saying, that every man will have Christ ror a saviour. . Jet if in truth we consider it, I assure you in plaine english, we wil not be saved; that is our resolution when it comes to the point."73

There is, then, one real difference between Cotton and Hooker: Cotton is considerably closer to calvin in his view of the conversion process. Fror cotton the process, though it might be painful, is much simpler than Hooker's conception and very much easier than Shepard's. Perhaps related to this is the fact that cotton in his preaching made much less of predestinetion and spiritual inability thar did his two notable contenporaries.

But it is difficult to make clear by means of quotation the essential dissinilarity of Hooker's und Cotton's sermons. Hooker, al thouch cloarly a man of the world, was much more demanding of his hearors than was Cotton, who was somewiat more genial though very much a scholat. One feels that many members of Cotton's congregition who were convinced.by his preaching that they were savrd would have beon much less hopeful of their chances in the other world had they been

72 It is verhaps inaccuritie to rofor to Calyin's preaching technigues, since he ris prinaily an exposiling preacher. inaccurite to refor to Calvin's preach-

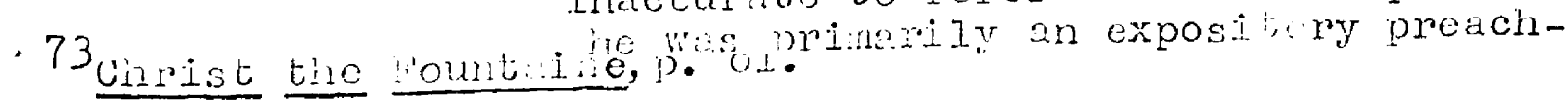


faced by a barrage of Hooker's sermons. 74

Let us see in what ways this study of shepard's and Cotton's writings bears on an evaluation of flooker's works. First, it makes quite clear that the differences mich exist anong the three most important Arnerican Puritan divines of their time are so considerable as to nake it difficult to apply to Cotton's or shopard's thought rindings made from Hooker's writings. Certain basic doctrines were held by ali three, but these are mostily points of dogina held by all ieformed theolorinns. On other points, such as the difficulty of conversion, ilookrep's views are sinilai to sineperd's, but different from Cotton's. 'lhus it appoars unwise to speak of

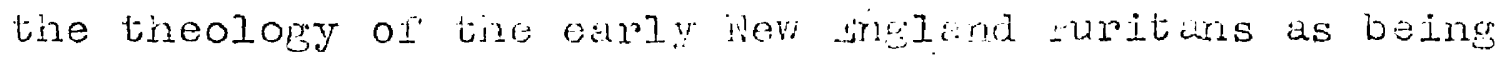
sonething unique and honogoneous. 75

Although our atudy or Cotion and sigepand ias not been as thopough as orr examinition ol yooker, inon the evidence

74 ivote tirat w' H. l'osber describes iookon's the souzes

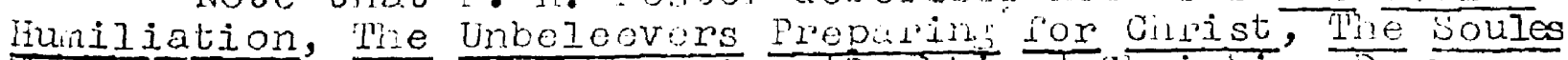
Vocation, and mile Poore Dyine [Dovbting] christian Drawne unto Christ" as "all verr "loomy," but ile finds cotton's l'se way of Life "ratior heloful"--i Genotic ilistory of the row ingland Theolory (chicho, $190 \%), p .30$ note).

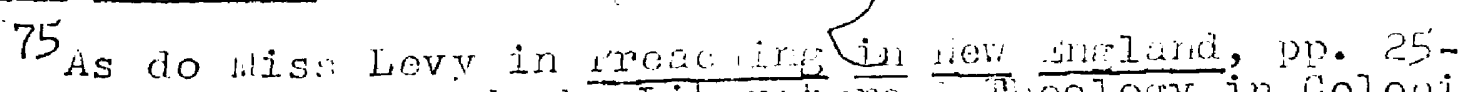

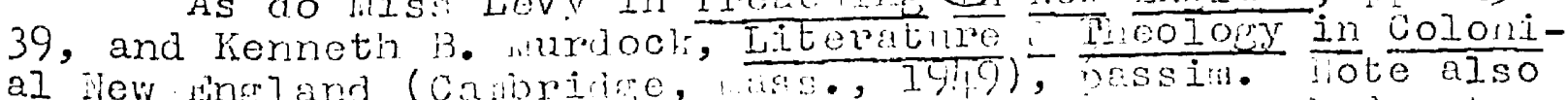

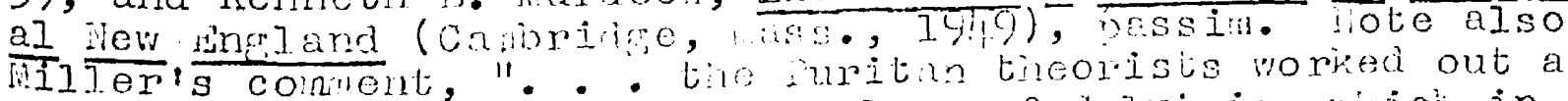
substantial ardition to tho theolory of jalvinis wicl in

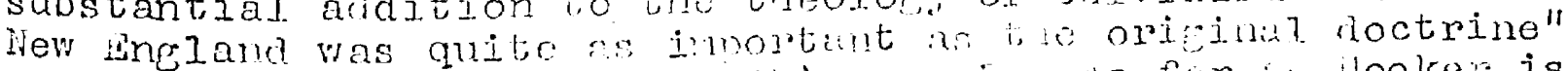
- -lhe Purituns (Jow yol, j, ji), p. $\because \%$ As fur a llooker is

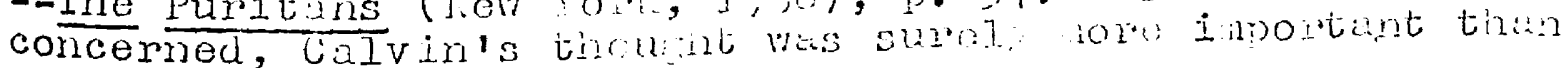
the addition, covenant ifolology. 
presented here the thought of Cotton and Shepard may impress one as sounder than Hooker's. "The techniques and teachings. of Shepard and Cotton have a simpier nature than looker's; the varied indirections of Hooker's techniques often strike the modern reader as mere tricks of preacining. ilooker probably developed these techniques as a result of being imbued with the spirit of the strict "iigh Calvinism" of the seventeenth century. Cotton, on the other hand, kept closer to Calvin. Shepard seems to have been almost as well indoctrinated with the spirit of Reformed scholasticism as Hooker, but his method was to rely on his powers of eloquence rather than on carefully developed techniques.

Probably rooker's greatest talont was his ability to describe, with real insight, types of unconverted sinners, presumably varieties with whon he had had expërience and whom he expected to be anong his hearers. Iis analyses wore doubtless effective means of reaching those who might otherwise have manked to avoid aplying to thomselves Hooker's admonitions, exhortations, ancl instructions. In their sermons Cotton and shepard likewise describe religious types. 76 But Hooker secris to have taken a particular pleasure in ins descriptions, ono perhass as a result they loom lareper in his works. Character analyses are to be found even in lis

76 The character was inciod al nost a stock preaching device. See Andrewes to ililiotson (Loidon, 1932), 0. 212-213. 
non-homiletic writings. The following example is from the -preface to Ames's Fresh Suit Against Iluman Ceremonies ([Rotteirdam? ], 1633).

The Temporary Gospeller having had some touch of Religion, $\varepsilon$ light of truth, in his mynde, can find no rest unto his conscience, unless he have some shew of reason to allege [for his actions]... Resolving therfor to decline, they seek to catch at any appearance, which they nay plead for their declining. And because they are most led by example, and sense, these are the weapons with which they use to ward then selves, d: naintain their course. Common cxample carries a perswading power with them, its a surficient reason for their doing because they see it don. Here they take up their stand. fill men for the most part do so, \& why may not they? Whus like sheep they follow the drove though it be to the shambles. ispecialy if they heare of any noted " famous for piety, \& godlines to goe in such a way, they conclude forthwith, it is the rightway: reasoning tius: They are wise \&: godly, 8. think you, they durst lo it, they would do it, unlesse it were rood and pious? when the truth hath told us, thet all men are lyers, \& eyther doe, or may deceive, or be decyved; even the courses of the

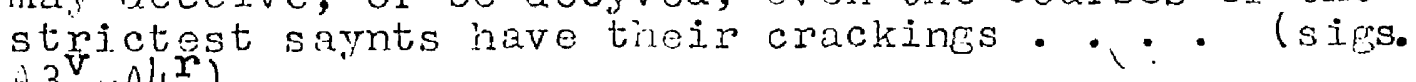
$\left.A 3^{v}-A L^{2}\right)$

Beyond tils, hooker's chief cluin to Gleatress as a religious tilinler is perings tiat lie was able to be at tre sane tine a "High Calvinist" and a viry effective evangelical preacher. Te was closer to tie opthodoxy of his day tran cotton or jinenard. Yet le was able to develop a series of preaching teciniquos which ride sossible botis a bold enphasis on man's soiritual inability in the strict orthodox fashion and a vicorous icmand that nan assune complete re-

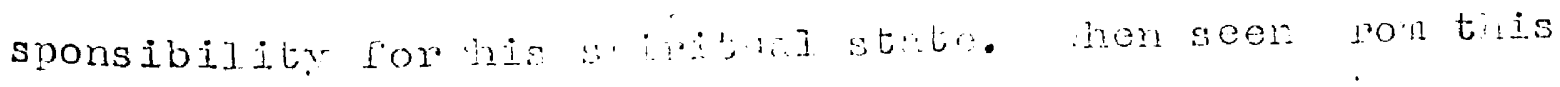
point of view, lonlor's nccasiongl wo lusinns anu departures 
from orthodoxy may seem less remarkable; his achievement was indeed a tour de force, though hardy an advancement in the xistory of religious thougint. 


\section{CONCLUSION}

As a result of our examination of Thomas Hooker's writings against his background--the thought of calvin, later Reforned theology, and Puritan doctrines-we have been able to come to some important conclusions about his tiought, conclusions which may help to clariry the history of ideas in seventeenth-century ingland and the rica.

First, we examined Calvin's thougit and its relation to later Refomed and Puritan teaching. In two important ways later Reformed and, more particularly, Puritan doctrine differ from Calvin's tholdght. First, Calvinism is theocentric: the Gloria Dei concept is central to his thought and permeates it. Puritan thourht, such as Hooker's, is much more anthropocentric; Puritan litereture has as its focus man's salvation. Second, after Calvin, Rerorned theology becaine codified and more precise. This cocification, combined with the shift of emphasis from God to man, caused Puritans such as Perkins and looker to insist much wore rigialy tian Calvin had thut natural man iras no spiritual abilities. This new emphasis was closely related to, and in fact part of, a view of predestination differont from calvin's. Whereas calvin taucint predestination--election and reprobation--to enphasize God's norcy, and, to a losser degroe, fis 
justice, for Hooker and other Puritans predestination was primarily considered for its role in the process of salvation.

In other ways Puritan teaching is much closer to Calvin's thought than many scholars have realized. filost important of these similarities is that in Calvin's teaching the conversion process is gradual and involves changes in the mind and the affections, and that conversion comes to those whose hearts are penitent and who have previously been exposed to the teachings of the gospel. Furthermore, there is evidence that in Calvin's teaching conversion is accompanied by persuasion. In these ways the thought of the covenant theologians is rather similar to that of Calvin.

Although it may be arrued that nooker was a covenant theologian, he made little use of the covenant-or-grace concept. In his preaching practice, he instead used the concept that preachine is the means of erace, as a basis for exhorting his hearers to be saved. This concept, taught by Galvin and develoned by later writers such as Preston, permitted Hooker to reconcile predestination with human exertion, for according to the theory God sees to it that only those predestined to salvation tite the steps necessary for salvation; yet these steps llooker attemptod to persuade all his hearers to take, for he could not know who vere elect and who were roprobute, Thus ioolser conld charge tat men should 
- i lay out their labour \& that unto the utmost of all their abilities never to give the Lord rest, non rest with their own souls, before they get this true. sight of sin, if ever they hope to see the work of Gods Grace in their hearts here in this world, or to see the face of God in Glory, in that other world to come. - . This is the way that God hath appointed and he wil bless, the order which he hath set in his infinite wisdorn and wich he will prosper. 1

Hooker's simplest statement of the doctrine of means shows clearly hcauses which keer) men from taking tire nrescribed steps. or Tr

it were God's will. that one of his hearers be damed, tooker eicould not of courso lnow. ile in know, fron wide experience, he commandeth, yet this shutteth not out their en-. deavor. IIis promise of enabling them is upon this supposition, that they doe indeavor in the use of meanes he silall aproint them. The Lord in promising doth not meane tinat they sirould be idle, and look that he should doe all; but his promising includeth their endeavourine, and upon their endeavourine in the use of the meanes that lod hatin appointed, ile hath prouiged to enable thell to doe wint he liath cormanded.2

This is the method which Hooker most often used to reconcile human responsibility and iivine grodestinution.

In his attempt to persuade, Hooker uses mary techniquos. Probably of first inportance is his effort to describe the causes which keer) men from tarting tire nrescribed sters. or it were God's will that one of his hearers be damned, Hooker could not of course linow. ile in know, fron wide experience,

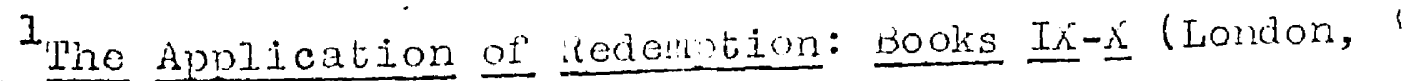
1657), i. 111 .

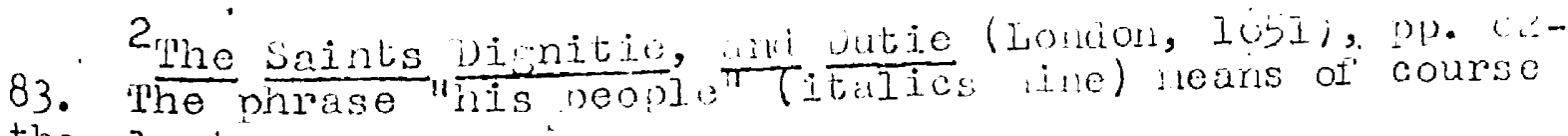
the elect. 
the devices-the "shifts" and rationalizations--by which nen often avoid usine the means of salvation, these descriptions he handled with real skill.

Hooker demanded much from those who would be saved. The process would be long and painful, and jiooker did not always offer much hope for success. One must, he taught, be willing to be damned before he could be saved. But although tile process was difficult, one could not rest, accordine to Hooker, after he had been convertied--or ratier arter he thought he had been converted.' Apparently in an effort to achieve in his hearors the sanctificntion which is supposed to follow effectual calline, Hooker taught that man must continually test himself in order to make sure that he is saved: he is not pernitted to have any basic concern otier than the question of his spiritual stite. Ho ambiguous role of conversion is an importunt weakness in ifooker's thought.

Another technique winch bolren comonly used is a nergative approach very aifferent, frou the positive approach demonstrated by the above quotations. Wiris tecirique was bo argue that God of fers erace as a gint, so thet if men rofuso it, they can be said to resist mace. 'the incompatibility of this approach with the laboribus strugriles which ilooker contends one must pass tirough in ordep to bo saved provides a real difficulty to tinose wo would respl jooker as an important religious thinkir. 
Cotton and Shepard, Hooker's contemporaries, were rather different in their teachings and techniques from Hooker, different enough so that it would be improper to consider the observations made regarding Hooker's thought applicable to other divines of Hooker's time. Cotton, al though in many ways as subtle a preacher as Hooker, was much closer to the teachings of Calvin than to the Reformed scholasticism of the seventeenth century, which profoundy affected Hooker's preaching practice. Shepard's theology was in many ways like Hooker's, but he made more extensive use of eloquence as a persuasive technique than aid jooker, and was also less prone to rely on psychological strategies. Hooker was a "Hich Calvinist"; this is abundantly clear. Although he occasionally sirayed froin the very narrow path of the ieformed onthodoxy of inis day, it would be difficult to find a Reforned preacher wo did not depart rrom the letter of the doctrines to which he subscribed. An exanination, of the semions of such a supposedly orthodox "Calvinist" as Jonathan wdwards will aemonstrate as much. Hooker was not wholly successful in iils attempts to reconcile the practical requirements of preaching with tile seventeenth-century Refomed concent; that man totally lacks syiritual ability. but this should not be survasing. It is noteworthy that he carlo as close to success as he cija. 


\section{SELECTED BIBLIOGRAPIFY}

\section{Hooker's Works}

Comnents concerning the works listed have been made when there has been some uncertainty on the part of previous students as to whether Hooker is to be regarded as the author, or when the present writer has found evidence wich has made him question the authenticity of worls hitherto accepted as ilooker's. Bibliographies referred to below are: Cambridge History of Anerican Iitcrature, I ('Cambriage, ing., and ivew York, 1918), 395-397, cited as Cambridge His-

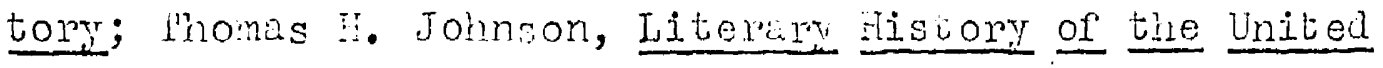
states, III (Wew York, 19h9), 568-569, cited as Johnson; Babette way Lovy, preaching in the Hist lalf Century of hew

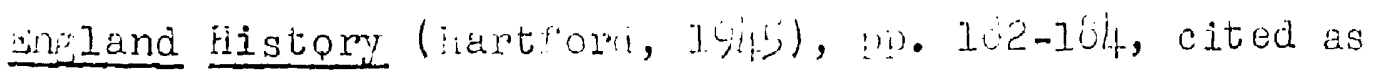
Levy; Joseph Sabin, A Jictionary of Books relating to tumerica, VIIL (New York, 1877), 410-4.23, cited as Sabin; and J. Hanmond l'rumbull, "Phonas Houker"s Published Volks," in George Leon wiker, phoms ilooker (iew yom, 1891); po. 184-

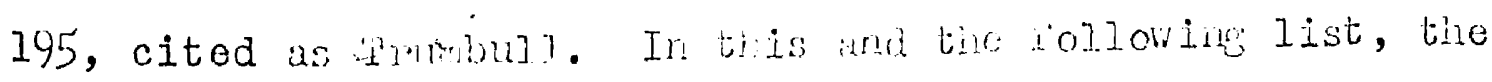
numbers assigned by rolland ni hod roo, jhort-pible cata-

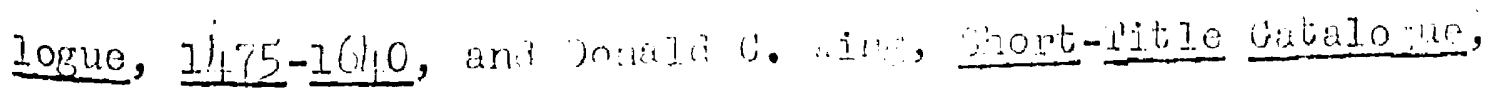


1641-1700, are listed, but publishers' names omitted for all

books printed before 1700. The library owning the pre-1700

books used in preparing this study is also listed.

The Application of Redemption, By the effectual Wiork of the Word of God, and Spirit of Christ, for the bringing home of lost Sinners to God. The first eight Books . . Printed from the Authors Papers, written with his own Hand, and attested to be such, in an Epistle, by thornas Goodwin and Philip lye. London, 1656. Uine $\#$ H-2639. inicrofilm of Library of Congress copy. (ipistle not found.)

The Application of Redemption By the Uffectual iork of the Word, and spirit of Christ, for the bringing home of lost Sinners to God. The Ninth and Tenth Boo $\mathrm{ss}^{\circ}$.. Printed from the Tuthors paners, "ritten with his own Hand. And attested to be such, in an Epistle, By Thomas Goodwin, and Philip lye. / ing ir 2640 . inicrofilm of Yale copt. Iondon, $16,7$.

A brief exposition of the Lords Prayer: wherein the meaning of the words is laid open to the understanding of weake Christians, and what the carriago of their hearts ought to be in preferrinc each petition. London, 1645. wine \#Fir-2642. microfilm of Huntington Librany copy.

The Christians Tvvo Chiere Lessons, Viz. Selre-Deniall, ind

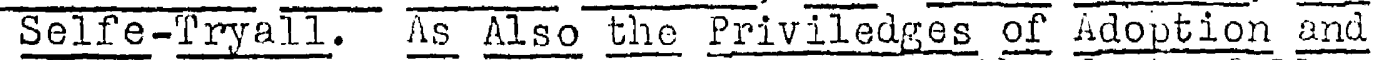
Trial thereof. In three ricatises on the Texts follow-

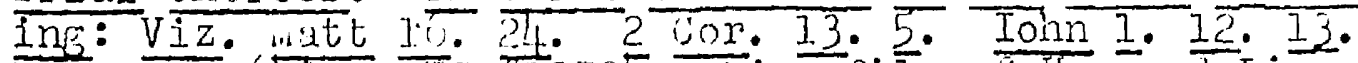

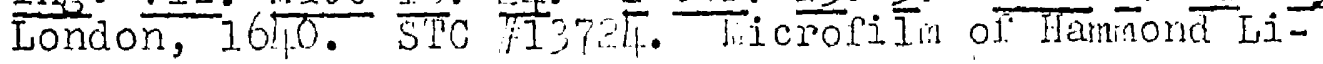
brary copy.

H Comment Upon Christ's iast Prayer In the Seventeenth of John. Wherein is opened, The Union beloeveris inve with God and Christ, and the clorious Priviledges thereof: - - Printed fron line Autiors onn Puners, viritten itin his own Fand. And attento to bo such, "win an pisto,

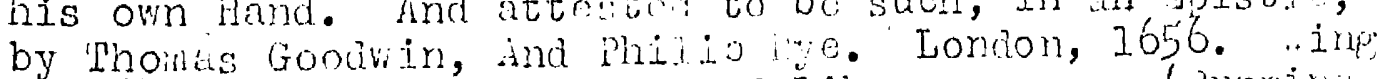

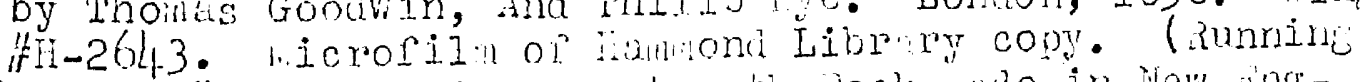
title: "wr" Hookor's soventeentic ijook wide in row-singIand.")

The Covenant of Grace openon: :herejn linese particilars are

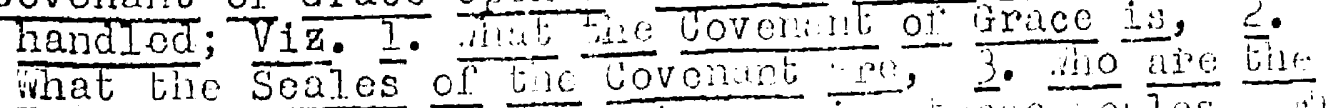

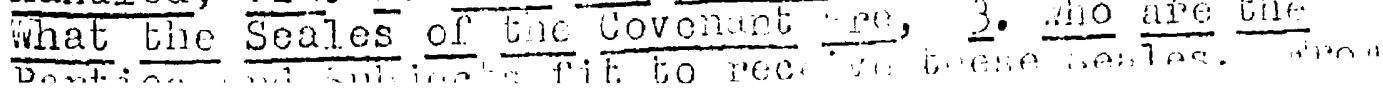


Ql] which Particulars Infants Baptisme is fully proved and vindicated. Being several I Sermons preached at

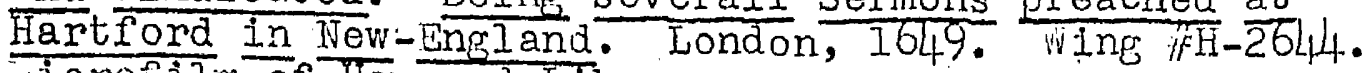
inicrofilm of Fammond Library copy.

The Danger of Desertion: or A Farwell Sermon of wir. Thomas Hooker - . Together Wth T'en Particular rules to be practiced every day by converted Christians: London, 1641. Wing tri-2b1.5. Miscrofilin of Library of Congress copy.

"To the Reader" (introductory epistie) in 'The Doctrine of Faith; Wherein are practically handled Ewelve principall points, which explaine the Nature and use of it, by Iohn Rogers. The third dition, new iy corrected, and inlarged by tine Author. London, 1629. S'PC \$21187. Harvard copy.

The Eqvall Wayes of God: Tending To the Rectifying of the crooked wayes of ten. The pass ages whereof are briefly and clearly drawne from the sacred scriptures. London, 1632 SI'C I2976. lificrofin of iluntington Library copy. LThis work is listed as Hooker's by Cambridge History, Johnson, Levy, Sabin, and "lrumbuil. STC lists it under Thomas Hayne. Title page lists it as by T. H. It does not seem to be Hooker's for the following reasons: (I) The work, accordine; to the preface, was prepared for the press by the author. But Goodwin and liye state that ilooker's earlier works were published without his approval. (2) Latin and Greek quotations are much more cominon in this work than in the works known to be Hooker's. (3) The author of this work refers to Socrates and Plato; ilooker nevor refers to secular authors. (4) the author has much nore concern with history than does looker. (5) the work is much less practical, more theoretical than fooker's works.)

An Exposition of the Princioles of Relicion. London, 1645. Wing ifH-2647. litcrof'ilim of Bodleian copy. ('this work is Iisted by Canbridge History as "Doublful." But title paige credits, it to "lho: Hooker. publisher's advertisement in The joules Preparcition lists it as another work by the same autior. Literary History and Levy list it as being hooker's. T'runbull indicates some doubt. line present writer has no reason to think it is not hooker's.)

The Faithful Covenantor. A vernon Preachea At tire Lecture

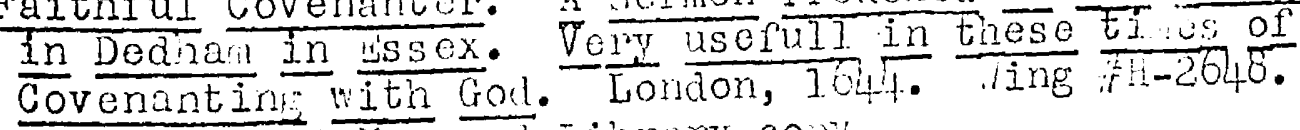
interofilin of llamuon isibrary con. 
Fovre Learned and Godly Treatises; Viz. The Carnall Hypocrite. The Churches Deliverances. The Deceltfulnesse of Sinne. the Benefit of Afflictions. London, 1638 . STC \#13725. Microfilm of Bodleian copy.

"Preface" to A Fresh Suit Against Human Ceremonies in God's Worship: or A Triplication unto D. Burgesse his Rejoin-

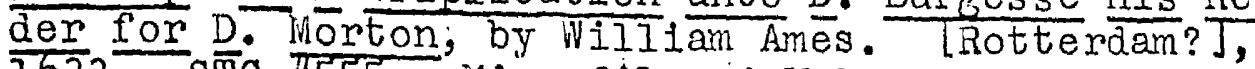
1633. STC \#555. Microfilm of Yale cony.

The Immortality of the Soule: The Excellence of Christ Jesvs, treated on. Wherein the faithful people of God may finde comfort for their souls. London, 1646. Wing \#H-2651A. Microfi Im of Huntington Library copy. (This work is listed on title page as by T. H. Levy and Sabin account it Hooker's. Cambridge History suggests that it is probably Hooker's. Trumbuli is doubteful. Johnson does not list it as Hooker's. The style of this piece is entirely different fron iooker's tense and nervous style; it is easy and flowing, as in the following sample: "God will give an eternal Kingdome of glory in heaven for ever, where tinere shall be rest, love, joy, peace, riches, honour, plenty and great knowledge, health, strength, beauty, and fulnesse of pleasure for evernore; and cod will wipe away all teares from their eyes, and place them in heavenly and glorious itansions, where we shill be berore oul' Glorious, excelient and mighty God and father, and his eternall love in Iesus christ, shining upon us to our everlasting joy and confort, and there we shall behold thousand tiousand billions of men women and children changed like Angels, shining as bright as the sun in the Fathers Kinglom . . ."-n. 10. On the bas is of styze this treatice cannot bo accouted as looker's.)

The Paterne of Perfection: Sxhibited in Gods Imase on tadull: And Gols covenant made with hin. Whorounto is adaed an Exhortation, to redeon the time for recovering our losses in the preinisses. Wn also sone liscellanies, viz. I. The prayer of Fith. II. A Treparative to the Lords Supper. III. The Character of a sound Christian,

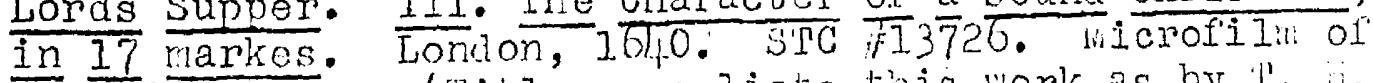
Bodleiancony. (Titie par lists this work as by $\mathrm{l}$. It is credited to Iooker by all bibliosraphies used excopt Jonnson, though Irumbul is somemat doubtful. Internal evidence-botin thool.ogy and stylo-points to Hooker as tie author of at loast tine inst tivo parts.)

"The Poore Dovbtine Cimistian vrawne unto Cinist. In One Sermon. nherein the maine letts wa hindrancus wich keope men fron combing to Christ uro discovered and pumorar chiefly tenting lo lay omn the necessity and 
excellency of Christ, and the promises: To empty us of selfe-confidence, and resting in our selves: And to show the weaknesse and insufficiency of all carnall props and reasonings whatsoever." London, 1629. In Richard. Sibbes et al. The Saints Cordials as they were delivered in Sundry selmons. Lońdon, 1629. STC IF 2503. Microfilm of University of Illinois copy.

The Saints Dignitie, and Dutie. Together with the Danger of Ignorance and Hardnesse. Delivered in Severali Sermons. London, 1651. Wing \#II-2654. hicrorilm of Hammond Library copy.

The Saints Guide, In Prnee Treatises: I The birror of Wiercie, on Gen. 6. 13. II The Carnall mans Condition, on Rom. I. 18. III The PIentation of the Righteous, on

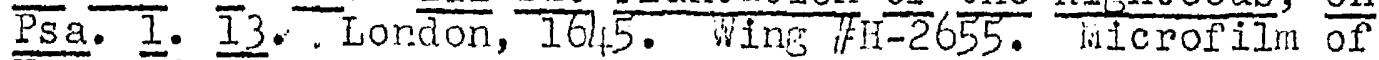
Harvard covy.

The Soules Exaltation. A Treatise containing The Soules Vnion with Cirrist, on I Cor. 6. 17. The Soules Benefit from vnion with Chist, on I Eor. 1. 30. The Soules Justification on 2 Cor. 5. 21. Lonnon, 1638 . STC F16727. Hicrofin of Hamnond Library copy.

The Soules Humiliation. Amsterdam, 1638. inicrofilm of Hammond Library copy. Not listed in GTC.

The Soules Implantation. A preatise containing, The Broken Heart, on isay. 57. 15. The Preparation of the Heart, on Luk. T. 77. The Boules ingraffins into Christ, on Wa]. 3. I. Spiritual Love and Jov, on Gal. 5. 22.

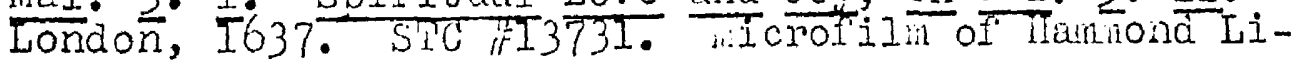
brary copy.

Whe Soules Ingrafting into Christ. Londion, 1637. Stlc

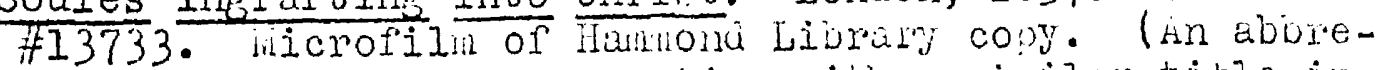
viated version of tho treatise with a sinilar title in The Soules Implantation.)

The Soules Possession of Christ: Shewing how a Christian should put on Cin ist and be able to boe all things through his strenth. The unto is annexed A Semon Preacied at tho iunerali of that Torthiv Divine vir. Wilmott, late inister of Ctare, in Suf rolke. London,

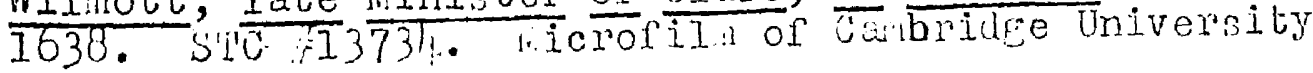
cony.

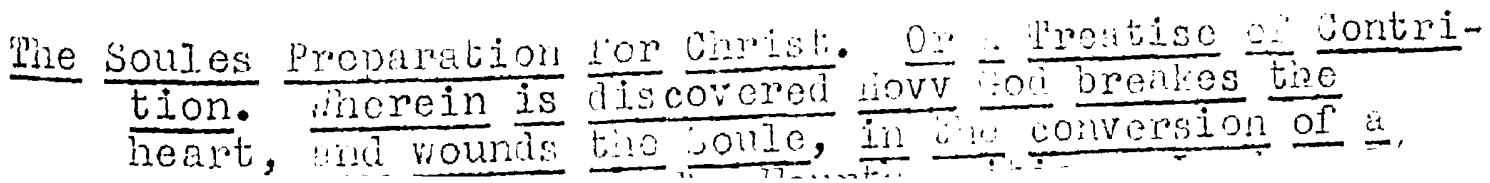


The Soules Vocation or Effectual Calling to Christ. London, 1638. STC \$13739. Wicrofilm or Hammond Library copy. (A socond title page lists this work as lhe sovles liffectuall Calling to Christ and ives the date as 1637.)

Spiritual inunition: A Funerall Semon. London, 1638. Bound with The Soules possession of Christ; see above.

A Survey of the Summe of Church Iiscipline. Wherein the way of the churches of ivew-tingland is warranted out of the Word, and all Exceptions of weight, which are made against it, answered . - London, 1648 . Wing FH-2658. Iilcrofilm of Library of Congress cony.

The Unbeleevers Preparing for Christ. London, 1638. STC 涪13740. inicrofilm of Fammond Library copy.

\section{Other Primary Sources Cited}

Adans, Thomas. The vorks of. Lid. illomas Sillth, with a imemoir by Joseph ingus. -3 vols. ilichol's series of Standard Divines, Puritan leriod. dinburght: Janes ivichols, 1861-1862.

Ames, william. The harrow of Sacrod Divinity, Drawne ovt of the holy scriptures, and the Interpreters thereof, and brousht into method. 'Translated out or tine Latine . -. London, n.d. ine if $\mathrm{A}-3001$. in icrorilm of Harvard copy.

- Conscience with the power and Cases tinereof. Divided into five Bookes. Iondon, Ibit3. in ing if $-2995 \mathrm{~A}$. ilicrofin of larvard cony.

Broniley, G. W., ed. üwinli and bullinger. Iibrary of Christian Classics, Vol. 21. Prilatelpilia: restminster Press, 1953.

Bullinger, Henry. The pecades. Pruns. I. I., ed. Thomas Ifarding. Prker ociety ublications, Vols. 35,39 , l.2, 47. Cambridge, ing.: University Press, $1849-1852$. - See also Bromiley, G. ".

Calvin, John. Ualvin: heolojical ireatises. H'w.s. and ed. J. K. S. keid. Library ol Unri. vian viassics, VoI. 22. Philadelphia: aestninster mon, 1954 . 
Calvin, John. Commentary on the Epistles of Paul the Apostie to the Corlnthians: Trans. John Pringle. Edinburgh: CaIvin Translation Soclety, 184.8 .

Leroy Nixon. Deity of Christ and other Sermons. Prans. 1950 .

- Four Sermons on Important Practical Subjects - - Drans. Henry Beveridge. Edinburgh: Calvin. Translation Society, 1851. Bound and paged consecutively with John Calvin, Comnentaries on the Epistles of Paul the Apostle to the Philippians, Colos ians, and Thessalonians. Trans. and ed. John Pringle. Edinburgh: Calvin Translation Society, 1851. . Henry ${ }_{\text {Beveridge. }} 2 \frac{\text { Institutes }}{\text { vols. }} \frac{\text { the }}{\text { London: Janes Clarke, } 1953 .}$ - The liystery of Godliness and Other selected

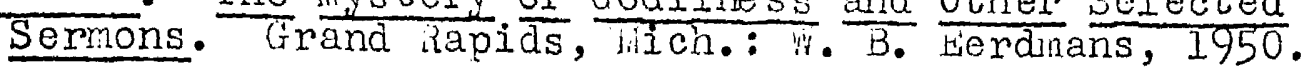
"Sermon on Luke ii. 9-14," in T. H. L. Parker, The Oracles of God: An Introduction to the Preaching of John Calvin. London and Redhili: Lutterworth Press, $\overline{1947}$.

- $\frac{\text { Sexmons }}{\text { genen of God }} \cdot \frac{\text { vpon the }}{\text { Moses }} \cdot \frac{\text { Commandenents of the }}{\text { Trans. I. H. }}$

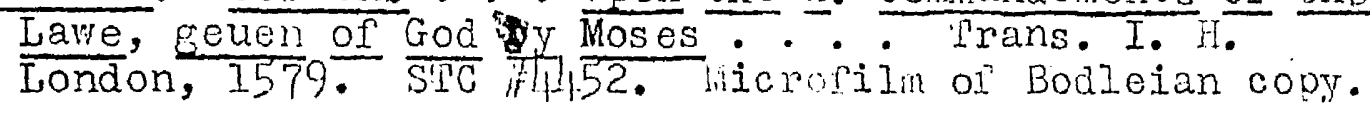
- Thirteen Sernons. . Entreating of the Firee lilection in Iacob, and of reprobation in sau. A treatise wherein euery Christian may see the excélient benefites of God $\cdots$. London, $15 \%$ STC $\% 4457$. liarvard cony.

- lvvo Gorly and lotable sermons ... The one concernynge racience in aduensicie: the other touchyne the most conlortable assuraunce of our saluation in

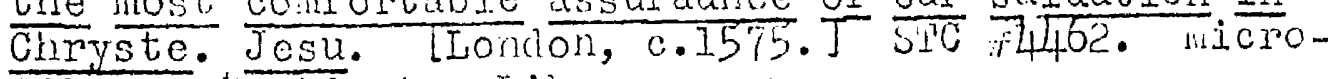
film of inutingtion Libran cony.

Certain Semons or ronilie: rprointed bo be Bead in Churches

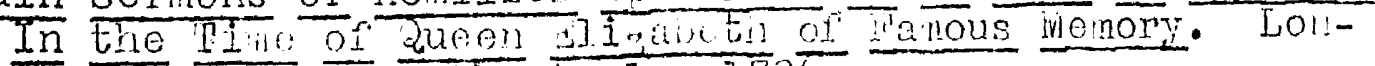

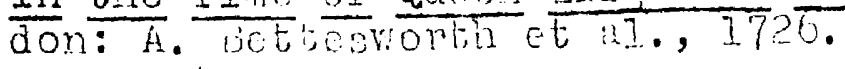

Cotton, Join. Christ the rountiline of Life: or, suncry Choyce Serinons on part of tho is tre Chapter of the finst Listie of t. John. London, To5I. \#C-6418. Hisuard copy. 
Cotton, John. Gods Hercie Mixed with his Iustice, or, His Peoples DeIiverance in times of danfer. Iaid open in several1 Sermons. Iondon, 164.1. Wing to -6433 . Harvard copy.

Milk for Babes. Drawne out of the Breasts of both pestaments. Chiefly for the spiritual nourishment of Boston Babes in either England: But it may be of use for any Children. London, 16.60 . wing $\mathbb{F C}-64, \frac{1}{3}$ inicrofilm of Huntington Library copy.

- The New Covenant, or A l'reatise, unfolding the order and manner of the giving and receiving of the Covenant of Grace to the ilect. As also: Shewing the difference between the Legalist and the true Christian. Being the substance of sundry sermons... . London, 1654. Wing if C-b4li?. Hiarvard copy.

- The way of Iife. or Gods way and Course In Bringing the Soule Into; keeping it in, and carrying it on, in the wayes of Iife and peace. Laid downe in foure severall Ereatises ... London, Ibli. ing TC-6!70. Wicrofilm of Yale copy.

Cudworth, Ralph. A Sermon Preached Before tine House of Commons, warch 3I, I04I. Teproduced Irom the Original sdition. New york: iracsimile lext society, 1930.

Firmin, Giles. The Real Christian, or a Preatise of effectual Calling. Where in The Work of God in Drawing the Soul to christ being opened according to the holy Scriptures, some things required by our late bivines as necessary to a right preparation for Christ, and true closing with christ, which have caused, and do still cause much trouble to some serious Christians, are with due respects to those worthy wien, brought to the BalIance of the Sanctuary, there weinged, and accordins Iy

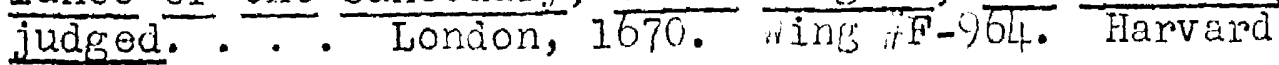
copy.

Hall, Joseph. Whe lorks of. I2 vols. Oxford: D. H. Halboys, 1837 .

The Heidelburs Catechism : - Ith an Historical Introduction. INew York: Scribner, $1863 . \overline{3}$

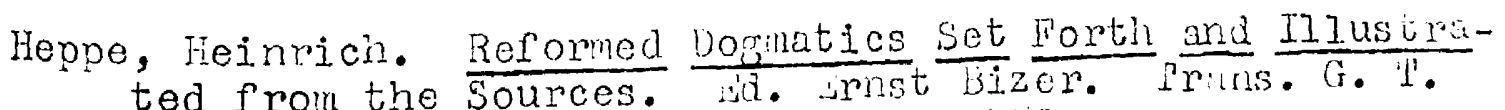
ted from the Sources.

Hooker, Richard. Whe ropls of. He. Join heble, v. by $R$. W. Churci and i. lapet. 7 til ed. ; vols. oxtord: University press, 1008. 
Hooper, John. Early Writings. Ed. Samuel Carr. Parker Society Publications, Vol. 11. Cambridge, Eng.: University Press, 184. 3 .

- Later Hritings of. Bishop Hooper together with his Letters and Other pieces. Ed. Whar es Nevinson. Parker Society publications, vol. 1,6 . Cambridge, ing.: University Press, 1.852 .

Knappen, h. i., ed. 'iwo Elizabethan puritan Diaries, by Richard Rogers and samuel verd. Studies in Church History, Vol. II. Chicago: Anerican Society of Church History, 1933.

Norton, John. The Sorthodox ivargelist. or a l'reatise Wherein many Geat bvangelical iruins (rot a few whereof are much opposed and isclipse in this peri ious hour

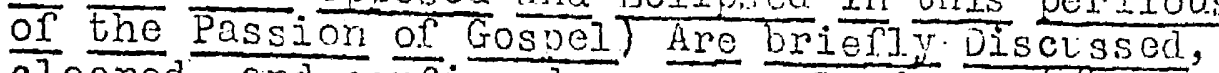
cleared, and confirmed. . . - London, I654. Wing ifN-1320. Tarvard copy.

Nowell, Alexander. A Catechism . . . sd. G. E. Comic. Parker Society Filications, vol. 53. canbriuse, Ling.: University Press, 1853.

Perkins, William. A Case of Conscience, the rreatest that euer vvas; Hovv a man inay krow whether he be tise cinizde of God, or no. Resolved by the Tord of God. Thereunte is added a brier discourse taken out or hier. Zanchius.

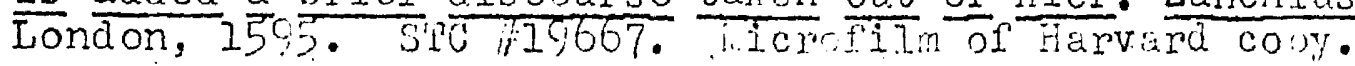

- A colden Chaine: or, The Jescrivtion of ineoloGie, conteining the order of the causes of jaluation and Damnation, Accoring to Gois Word. Is viow wereof is to be seene in the lable arinexed. Hereunto is adioyned the ordor wich ine Theolone weza used. in coinfortine ar licted consciences. Canbride, ing., IEv.

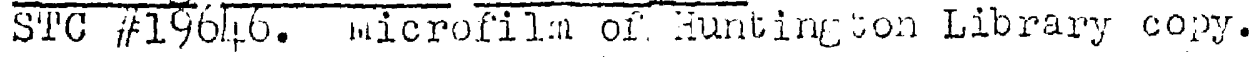

A ireatiso tending vnto a declapution wistirg a man be in the ectide of damnation or ir the estute of grace; and if hebe in the first, 10w he may intine come out of it: if in the second, lon me is discerne it, and perseuere to the ent. . London, [1589]. STC

STC ifig650. Thonl:es of. 2

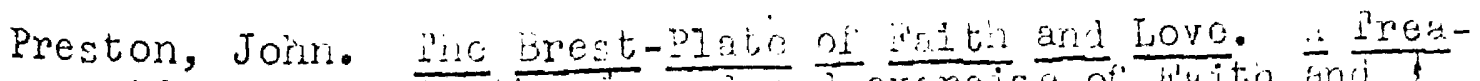

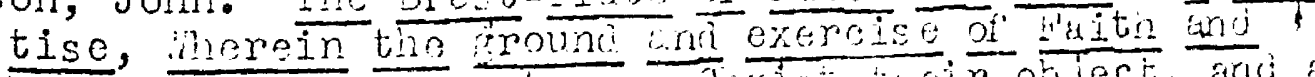

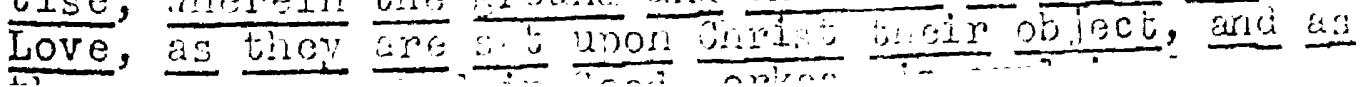


Delivered in 18 Sermons, upon three severall l'exts. The Sixth Edition. London, 165I. Wing $17 \mathrm{P}-3301$ Harvard copy.

: The lievv Covenant, or The Saints Portion. A Treatise vnfolding the AlI-sufficiencie of God, lians uprightness, and the Covenant of grace. Delivered in fourteen Sermons - The Wirnth idion, corrected. London, 1634. STC $\$ 20246$. liarvard copy.

- The Position of John Preston . . Concorning the Irresistiblenesse of Converting Grace. London, 1654. Wing $\$$ P-3305. Hichilm of rale copy.

- The Saints unalification: Or A treatise I. Of Humiliation, in Tenne Sermons. II. Os Sanctification, in nine Sermons: Therevnto Is Added a preatise of Communion with Christ in the a a rament, in three sermons. Second edition, Corpected. Lolldon, 1034. STC 720263. wicroila of University of Chicago couy.

Reici, J. K. S., en, see baivin, Jom. Culvin: weolopical Proatises.

Robinson, liastines, ed. The Zuricin Letters, conprising the Corresuondence of several Endisir Bishops and Others, with some of the relvetian ielcriers, during the Early Part of the Reign of ween wizabeth. Parker society Publications, Vols. 7 and 10 . Conbriage, Lre. : University press, 18 l! $2-18,5$.

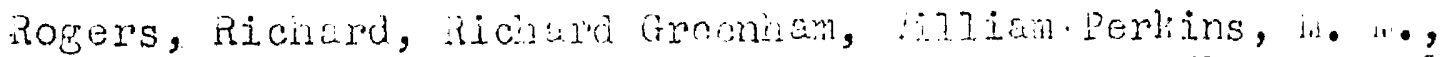
and George eboe. At Garden of airitarl powers. 2

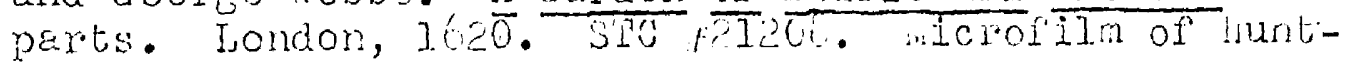
ington Iibm som.

Sandys, edwin. Sernons . - sone were of were proached In the parts beyont the seas, In tir timo of his oxilo, in the raigne of ueene waric the rosiciue in such plines of prefernent as de njoyad under her late majesty, Queene ulizabotin, of funous nenorie. - London, 1616. STC

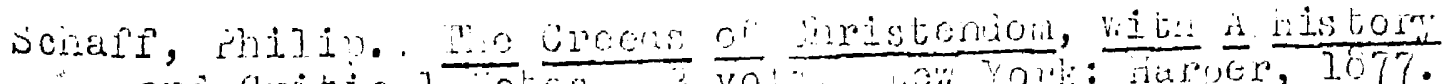

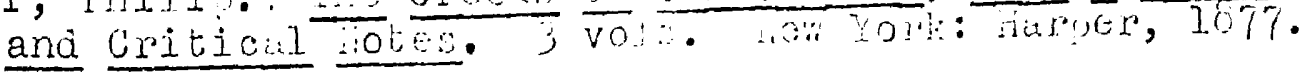

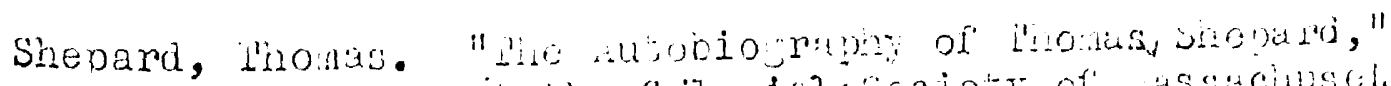

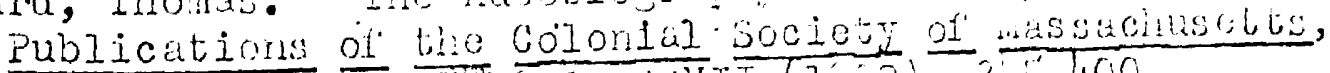

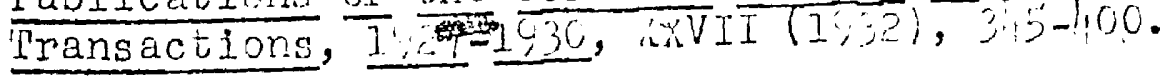

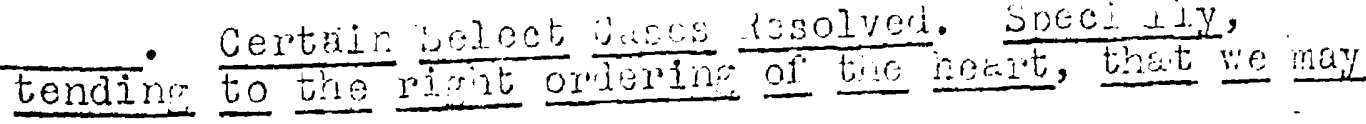


comfortably walk with God in our general and particular cal1ings. London, 1650. Wing is-3104. Nicrofilin of Hammond Library copy.

Shepard, Thomas'. The Sincere Convert: Discovering the gmall number of true Beleevers, And the creat difficulty of Saving Conversion. - . London, 1655. Wing \#S-3125. Microfilm of Yale copy.

- The Sound Beleever. A Treatise of Ivangelicall Conversion. Discovering the work of Christs spirit, in reconciling of a sinner to God. London, 1652. Wine is -3135. lificrofilm of Hammond Library copy.

- Subjection to Christ in all his Ordinances, and Appointments, The best means to vreserve our Liberty. Together with a Treatis of Inefectual Hearing the Word; How we may know whether we have he ard the same effectualiy: And by what means it may become effectuall unto us. with solne remariable passages of is ilfe.

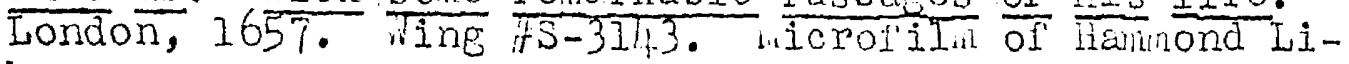
brary copy.

Sibbes, Richard. The Brvised reede, and binouring Hax. Some sermons : : Tile fourti wition, corrected. London, 103?. STC it22482. Hurvard copy.

Smith, Henry. The vorks of Wenry Suitu, Including Sernons, Treatises, Prayers, and Poens. Td. Thomas Srith. 2 vols. Nichol's Series of Standari Divines, iuritan Period. Edinburgh: Janes Michol, $1866-1067$.

wara, Samuel. See Knapren, li. li.

Willard, Sanuel. A Compleat soir of Divinity in lyo ilundred and Fifty ixoository Lectures on the Assembiy's Shorter catecinin inepein Fie doetrines of the Unristian Jeligion are mfolcled.. boston: D. Silot and $D$. Tionciumat, 7726 .

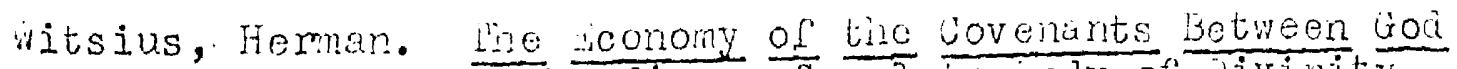
and inan. Co brenending a conge boly of Jivinity.

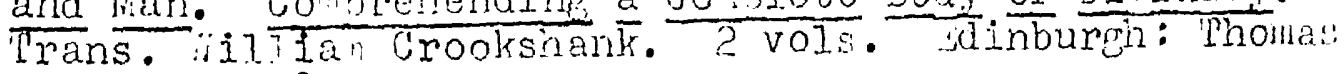
Purnba1.1, 1803.

\section{Secontury sources lituci}

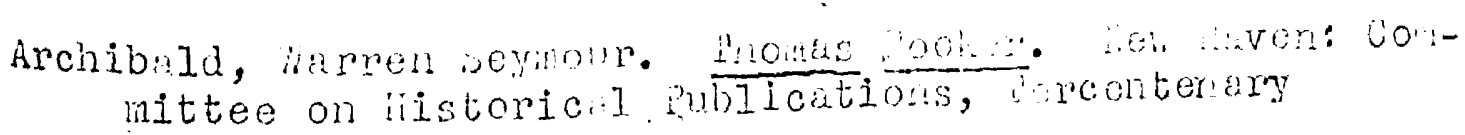


Commission of the state of Connecticut, 1933.

Bainton, Roland $H$. The Reformation of the Sixteenth Cen- . tury. Boston: Beacon Press, I952.

Baker, Herschel. The Wars of Truth: Studies in the Decay of Christian Humanism in the tarlier Seventeenth Century. Cambridge, Mass.: Harrvard University Press, I952.

Battenhouse, Roy. "The Doctrines of man in Calvin and in

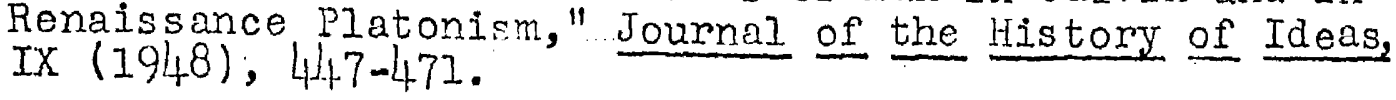

Bayle, Pierre. Dictionnaire Historique et Critique. ivouvelie ed. 16 vols. Paris: Desoer, 1820 .

Beard, Charles. The Reformatian of the Sixteenth Century in its Relation to Wodern Thought and hinowledge. 3rd ed. The Hibbert Lectures, 1883 . London: Whliains and Norgate, 1897.

Bind off, S. T. Pudor England. The Pelicin listory of England, Vol. V. Hamondsworth, ijddlesex, Engl: Penguin Books, 1952.

Brauer, Jerald $c$. "Reflections on the Vature of inglish Puritanism," Church History, XXIIJ (1954), 99-108.

Bronkema, Ralph. The assence of puritanisil. Goes, Iloliand: oosterbaan \&: Le Cointre, 1929.

Bush, Douglas. inclish Iiterature in the grapier seventeenth Century, 1600-1660. Oxford Iistory of Jing ish Literature, Vo1. V. Oxford: Clarendon press, 1945.

Campacnac, is. T., od. Lho Cambridge Patonists. Oxford: Clarendon Press, 1901.

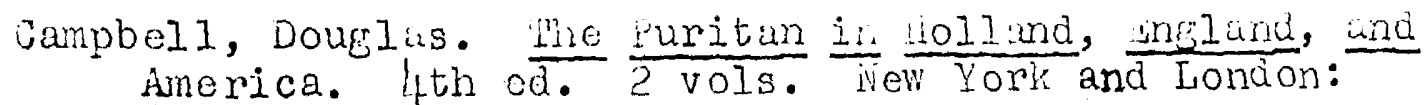
Harper, 1099.

Chester, Allan G. ilugh Latimer: Anostlo to the inglish. Philadelonid: University or Fennsylvinia pess, IS54.

Christy, Wayne Horron.- "John Cotton: Covenant Thenlogian." Unpub. M. A. thesis, Duke, 14/42.

Citron, Bernhard. Hew Birtu: A Study of the evangelical Doctrine of conversion in the potestint iinthers. Ddinbureh: Univoreity pros, 1 inl.

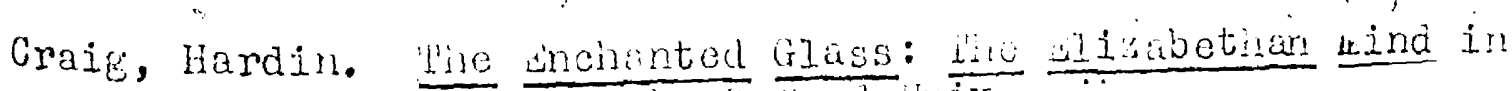

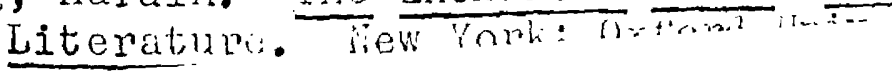


Cunningham, William. The Reformers and the Theology of the Reformation. 2nd ed. Edinburgh: T. and T. Clark, 1866.

Davies, Horton. The Worship of the Inglish Puritans. Nestminster: Dacre press, 1948.

Dawley, Powel Mills. John Whitgift and the Unglish Reformation. New York: Scribner, I95/4.

DeJong, Peter $Y$. The Covenant Idea in Hew England lheology,

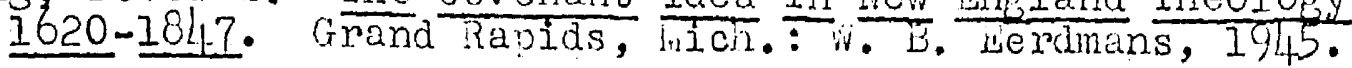

The Dictionary of iational. Biograpiny. 21 vols. London: oxford University Press, 1949-1450.

Dorner, J. A. History of Protestant theology, particularly in Germany, Vielied According to its Fundenentil livovement and in Connection with the Relisious, Worial, and Intellectual Life. irans. Geore tobson and Sopinia Taylor. 2 vols. idinburgin: I. 2 T. Clark, 1071.

Doumergue, E. Jean Colvin: Les homos et les choses de son temps. 7 vols. Lausanne: Geopes - Bude1, I899-1927.

Dowden, John. Outlines of the ristory of bie lheolosical Literature of the Cinureh of Linch from the Refomation to the Close or tine Bishteonth Centiry London:

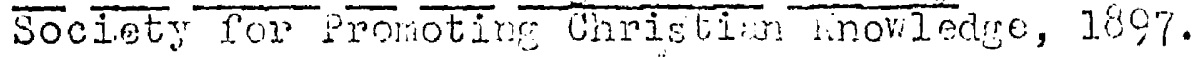

Dowey, Jdward A., Jr. The knowledse of God in Calvin's ine-

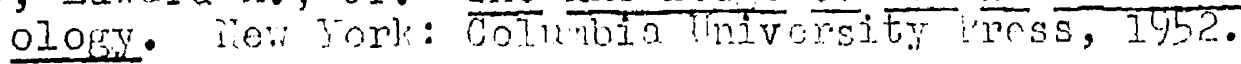

incyclopaedia Britannica. 14th eù. ah vols. uhicago: Encyclopaecia Britannica, Inc., 1955.

encyclopaedia of Relinion and thics. 12 vols. wov Yont: Scribner, Iy

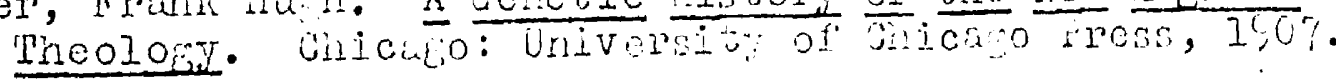

Foster, lierbert D. Collected Papers of. Ranover, i. i.: Privately orint $19,1929$.

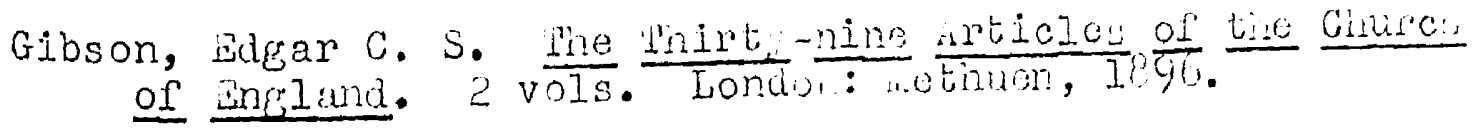

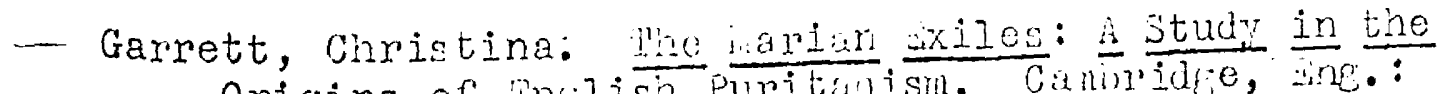

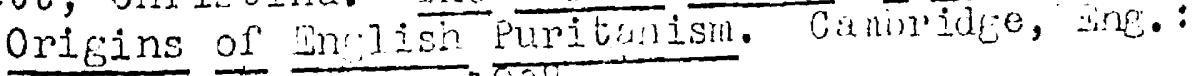
University press, 1938.

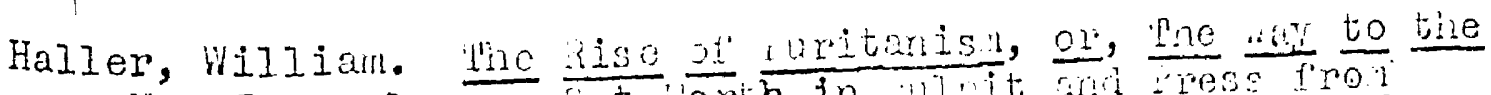

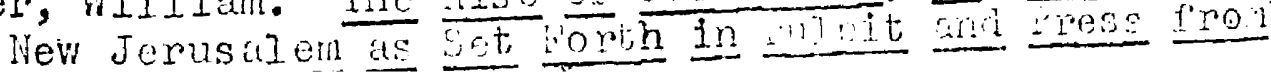


Thomas Cartwright to John Lilburne and John hil ton,

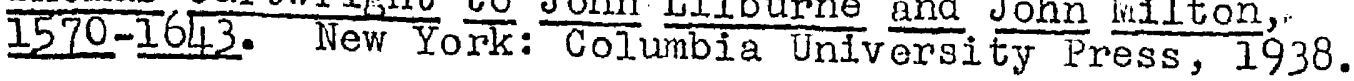

Hens on, H. Hensley. Puritanism in England. London: Hodder and Stoughton, 1912 .

Herr, Alan Fager. The Elizabethan Sermon: A Survey and a Bibliography. Fhiladelphia: Universit $\frac{\text { Survey }}{\text { of Penrisylvania, }}$

Hopf, Constantin. Hartin $\frac{\text { Bucer }}{\text { Oxford: Basil }}$ and the English Reformation.
BI, 1946.

irughes, Philin. The Reformation in England. Vols. I-II. London: Hollis \& Carter, 195 I-1954.

Hunter, A. bitchell. The Teaching of Calvin. 2nd ed. (revised) London: James CIarke; 1950 .

Inappen, iri. ii: Iiudor Puritanism: A Chapter in the History of Idealism. Chicago: University of Chica po Prèss, 1939.

Kuiper, Heman. Calvin on Connon Grace. Goes, Hetherjands: Oosterbaan o Le Cointre; Grand Rapids, mich.: Smitter Book Company, 1928.

Levy, Babette r.ay. Preachine in tho irirst half Century of New England History. Studi es in Church History, Vol. VI. Fartford, Conn.: American Society of Church Iistory, 194.5 .

liather, Cotton. hagnalia mpisti Hericance, or wine Leclesiastical History of iew-England, from the First plantine in the year 1620, unto the vear of our Lord, I60, lst American ed. from the London ed. of 1702. 2 vols. Hartrord: Silas Andrus, 1820.

licGiffert, Arthur Cusinen. Protestant llougit Before rent. lvew York: Scribner, 1911.

wcireill, John 'l'. The History and Character of Calvinism. New York: Oxrord University ress, 1954 .

head, Idwin D. "Thonas Booker's Frewell sermon," hassaciu-

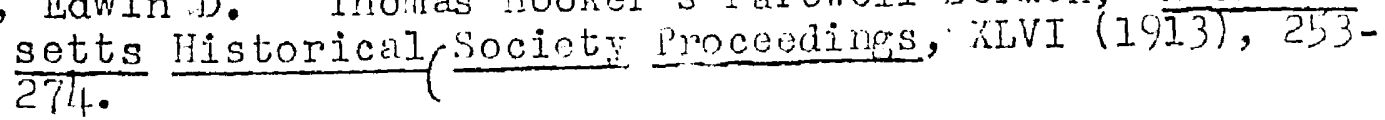

luillor, Perry. "wile warrow of puritan Divinity, "rublications of the colonial society of inssacinuetts, Transactions, $1933-1937, k$ KII (1938), 247-300. 
Miller, Perry. The New England Mind: From Colony to Province. Cambridge, hass.: Harvard Univorsity Press,

The New England Mind: The Seventeenth Century. Cambridge, Mass.: Harvard University Press, 1954. $\frac{\text { Study }}{1932 .} \cdot \frac{\text { Orthodoxy }}{\text { Cambridge, inass.: Harvard University Press, }}$

"Preparation for Salvation' in seventeentis IV $(194+3), 253-286$.

- "The puritan-Theory of the Sacrdments in seventeentl Century ilow urer and, "Cacholic ilistorical Review, XKII (1937), 409-425.

- "lhqinas ilooker and tho Denocracy of wingy Connecticut," Her Indrand quarterly, IV (I93I), 663-i12.

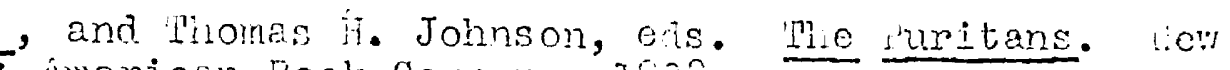
York: 4morican $300 \mathrm{k}$ Company, 1930.

witchell, texander. "The Theologr of the Reformed Churcin vith Special Reference to the vegninstor Stuniards," in Report of Proceedins oi tie jecond General Council of the Prestyterian Alliance, Convened at philadelphia,

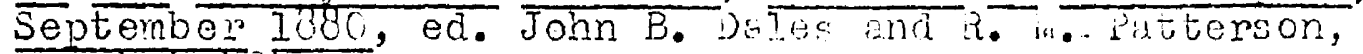

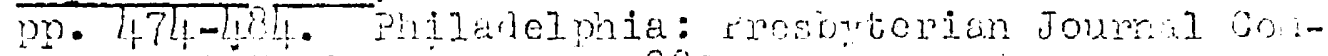
pany and $I$. C. accurdy, 1880.

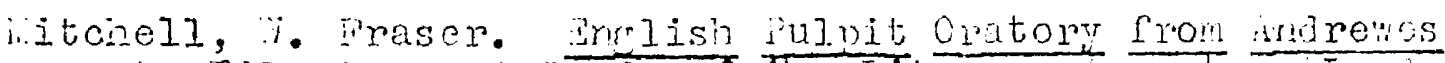
to Tillotson: a study of its Literary aspects. London: society for ronoting Thristian Knovlede, 1932.

inofiat, James $\mathrm{J}$. "The Influence of Calvin on keligious "Phought," tubum jominem Record, V (19;09), 157-160.

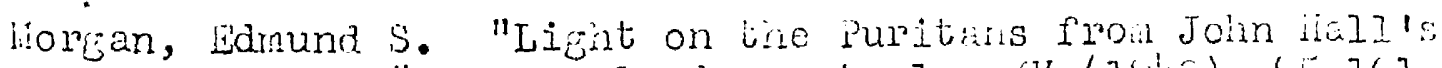

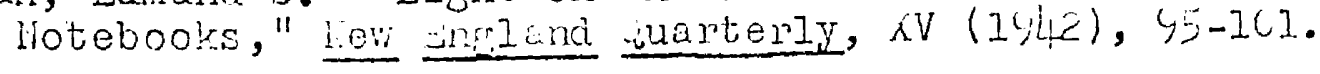

- The Puritan ramily: Essays on icligion and Domestic Relations in seventeenth-centum iew enciarid.

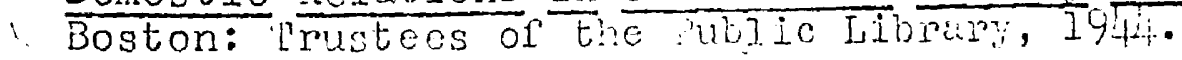

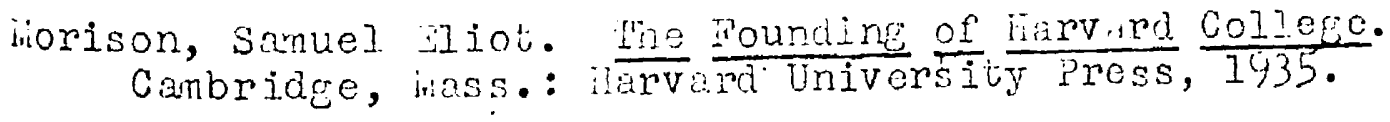

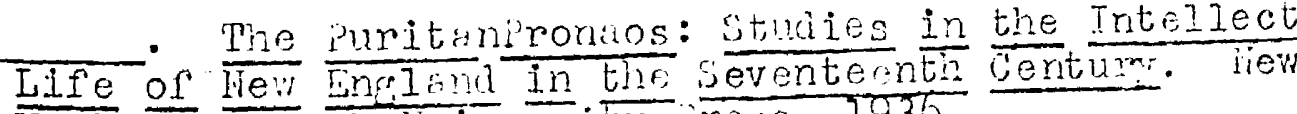

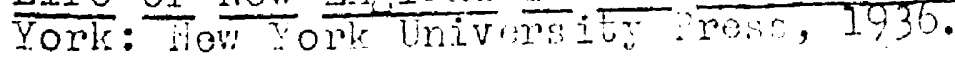


Moss, Claude B. The Christian Faith: An Introduction to Dogmatic Theology. London: Society for Promoting Christian Knowledge, 1943.

Hurdock, Kenneth B. Iiterature \& Theology in Colonial New England. Cambridge, liass.: ilarvard University Press, 1949.

Neal, Daniel. The History of the Puritans; or Protestant Nonconformists from the Reformation in 1517 to the Revolution In $1688 . \div 5$ vols. London: William Baynes and Son, 1822 .

New Schaff-Herzog Encyclopedia of Religious Knowledge. 12 vols. New York and London: Irunk and ivenalis, 19001912.

Nixon, Leroy. John Calvin, Expository Preacher. Grand Rapids, wich.: W. B. Eerdinans, 1950.

Notestein, Wallace. The inglish Peonle on the we of the Colonization, 1603-1630. The liew Ame rican ivation Series, Vol. I. NoW York: Happer, 1954.

Iuttall, Geoffrey F. The Holy Spirit in puritan Faith and Experience. 2nd ed. Oxford: Basil Blackmeli, 1947.

Olert, John, Jr. "Predestination: Gilvin and vile inew ingland Theology." unpub. 'th. the thesis, union ineological Seminary, isew York City, 14,3..

Olsson, Karl Arthux. "Theology and Rhetoric in the writings of Thomas Shegard." Unoub. discortation, Chicago, 194.0 .

Panp, Frederic E., Jr. "Studies in tho opigins of inglish Aminianism." Unmub. disscrtation, harvard, 14,50 .

Parker, T. H. L. The oracles of Gor: in Introduction to the Preachine of Join Colvin. Lonuon and Kedhill: Lutterworth Press, I947.

Parrington, Vernon Louis. Hain umpents in wropican

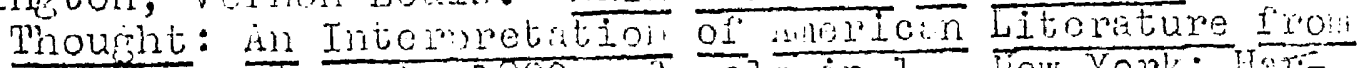
the Beginninge to lgec. 3 vols. in 1 . liow Yoll: Hor coure, Brace, ITIT.

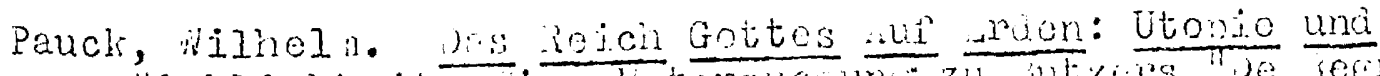

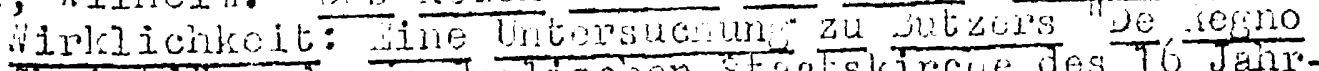

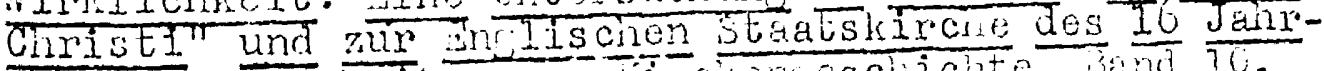

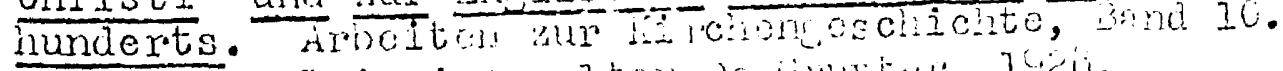

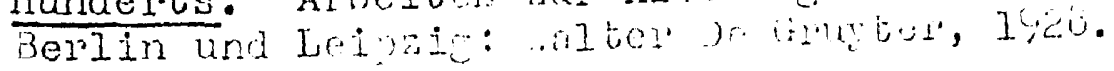


Pauck, Wilhelm. The Heritage of the Reformation. Glencoe, II1.: Free Press; Boston: Beacon Press, 1950.

Perry, Ralph Barton. Puritanism and Democracy. New York: Vanguard Press, 194t.

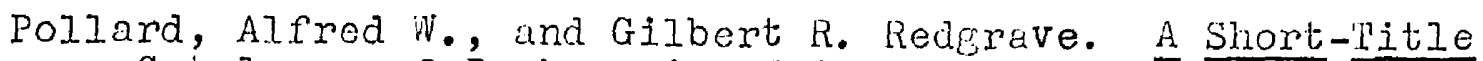
Catalorue of Books Printed in singland, Scot land, Ireland and of tnglish Books printed Abroad, $1475-1640$. London: Bibliographical Society, 19ाt6.

Ritschl, 0tto. Dormencescinichte des protestantismus. Band TII: Die repormierte Theologie des 16. und des 17. Jahrhunderts in ihrer instehune und intwicklung. Guttingen: Vandeníoeck 8 Ruprecht, 1926.

Rossiter, Glinton. "ihomas iooker," Wew ingland quarterly, XXV (1952), 1.39-488. Also published in his seedtime of the Republic: The Origin of the American Tradition of Political Liberty. Ilew York: Harcourt, Brace, 1953. Rowse, A. L. The Trigland of $\frac{\text { Elizabeth: The Structure of }}{\text { Society. Thew }}$

Sabin, Josepin, et al. A jictionary of books relatine to America From its piscovery to tire Present tine. Vol. VIII. Jew York: J. Sabin and ion, 1877.

Sanderson, Robert. See Walton, Isaac.

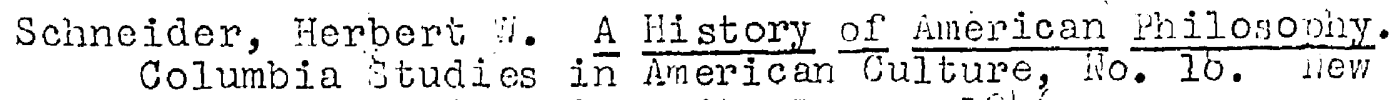
York: Columbia University Press, I9hb.

Schrenk, Gottlob. Gottesreich und Bund im alteren irotestantismus vornehmlich boi Johannes Goccejus. Beitrüe zur Forderung cirristicho Theoloie, 2. Keine, 5. Band. Gttitersloin: C. Sentolsmann, Ig23.

Smith, Lewis. "Chanfing Conceptions of God in Colonitul lew ingland." Unprb. dissertation, state university of Iowa, 1953.

Sinyth, C. H. Cranner a the Reformition under udwand VI. Cambridee, Ine.: University pross, $\overline{1926 .}$

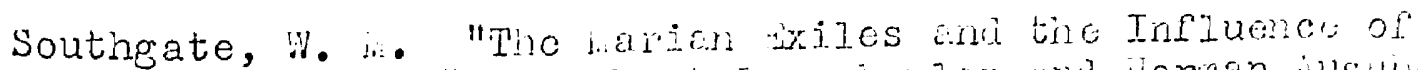

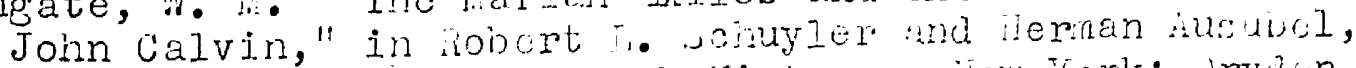

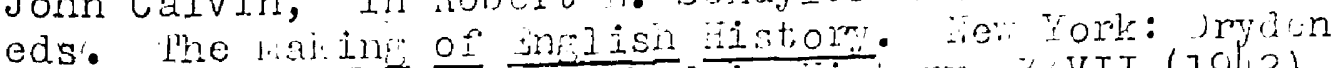
Press, J.552. Also ublinted in istory, K.VII (I9L2), $148-1.52$. 
Spiller, Robert E., H. S. Canby, W. L. 'lhorp, and T. H. Johnson, eds. Literary His tory of the united states. 3 vols. New York: liacmilian, 1949.

Stearns, Raymond Phineas. The Strenuous Puritan: Huch Peter, 1598-1660. Urbana: University of IJjinois Press, 1954.

lirent, W. P., et al. The Cambridge History of American Literature. Vol. I. Cambridge, eng,: University Press; New York: Putnam, 1918.

Irinterud, I. J. "The Origins of Puritanism," Church History, XX (1951), 37-57.

"1roeltsch, E. "Calvin and CaJvinism," Hibbert Journal, VIII (1909), 102-1.21.

Trans. Olive Vyon. $\frac{\text { vols. London: }}{2 \text { Allen }}$ Unwin, 2949.

Walker, George Leon. Thomas loolen: Hpacher, frounder, Democrat. Wakers of Anerica Series. New York: Docid, li:ead, 1891 .

Walker, Williston. John Calvin. How Yopk ank London: Putram, 1906.

walton, Isaac. "ihe Life of the acvorend and Learned huthor," in Robert "uanderson. KKAVI Sermons. . . l'se Eightin edition; corrected and hinended. London, $16 d 6$. Vine its-638. Personal con.

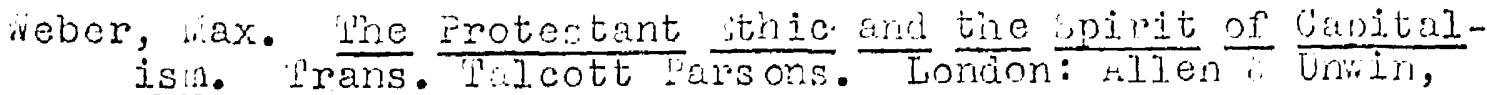
$\overline{1930}$.

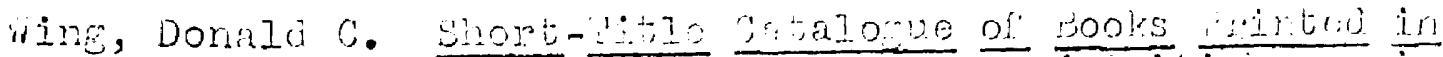
theland, scotland, Irelund, wlos, ant mitist merict

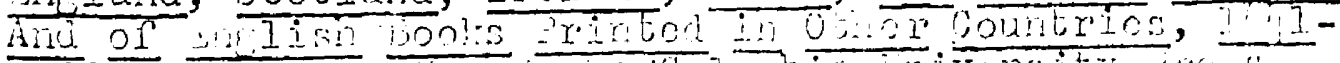

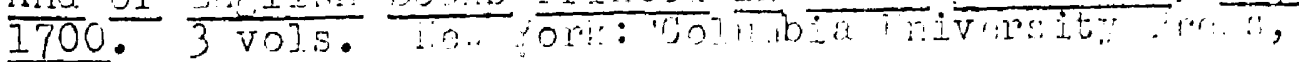
19ा!5-191.

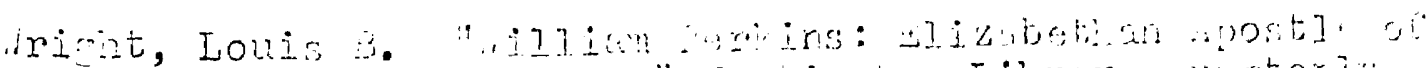

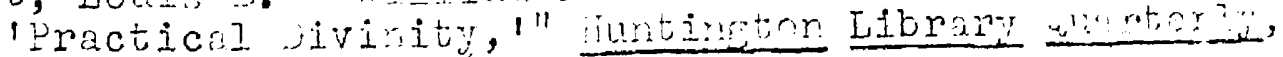
III $(I, 40 \%$, III-I \% 


\section{VITA}

Everett Harvey تnerson was born at walden, masachusetis, on irebruary 16, I9,5. Jie attonciod sorott, hassachusetts, public scirools anc was gradudied in 1 y 3 from uverett Fign school. Troin 1943 to 1946 he served in tile larine Comps, part of his periol of servico being at iartmouth ciol-

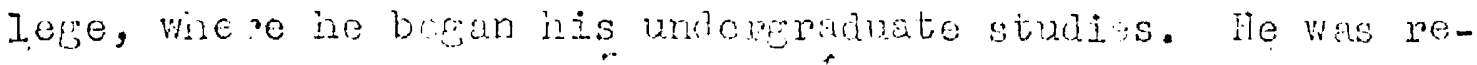
leased from the sorvice as a secomi ticubonati. In Iyt and

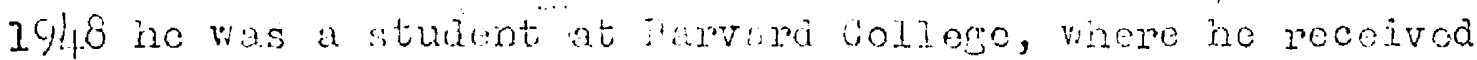
the A. 3. dorree in 1y/g. lie bogan his grambe studies in inflish at Duke inivas ity, whone in 1949 he received the

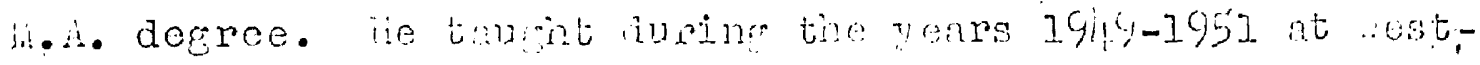

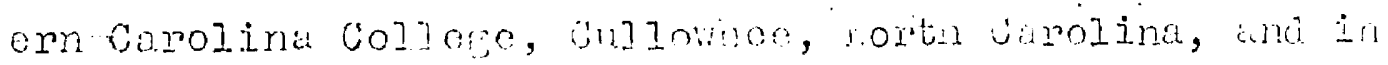

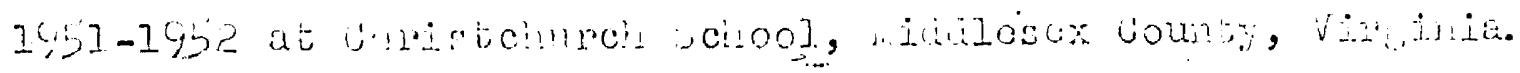

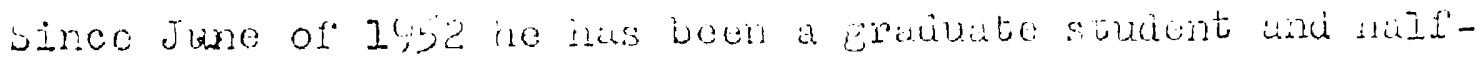
wine instructor at jouir jesa state Lniversity.

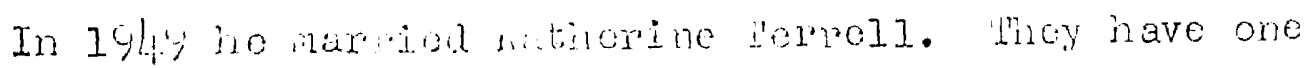
son, itenizen, bom in 1950. 
EXAMINATION AND THESIS REPORT

Candidate: Everett Emerson

Major Field: English

Title of Thesis:

Thomas Hooker and

the Reformed Theology
Approved:
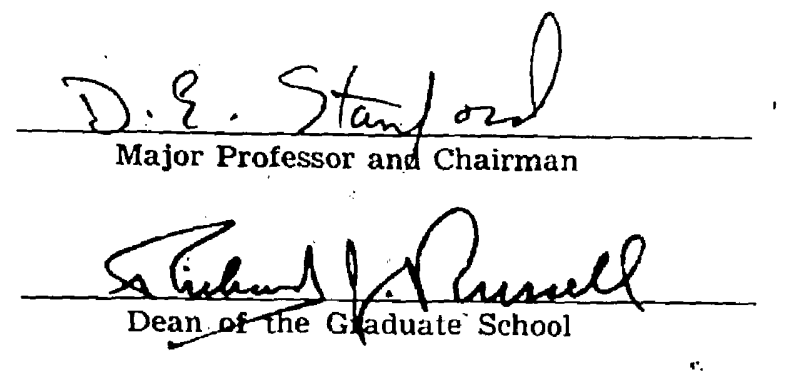

EXAMINING COMMITTEE:

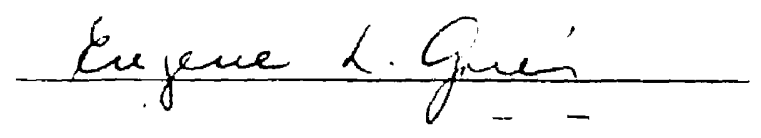

b)
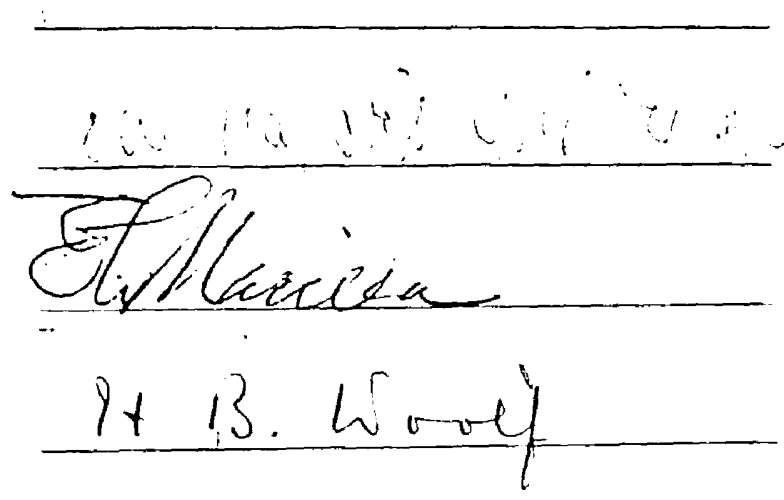

Date of Examination:

May 5; 1955 